\title{
Introducing the Dihydro-1,3-azaboroles: Convenient Entry by a Three-Component Reaction, Synthetic and Photophysical Application
}

Jun Li, Constantin G. Daniliuc, Kalathil K. Kartha , Gustavo Fernández, Gerald Kehr, Gerhard Erker*

\section{Table of Contents}

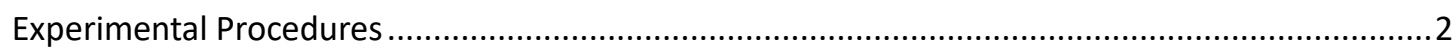

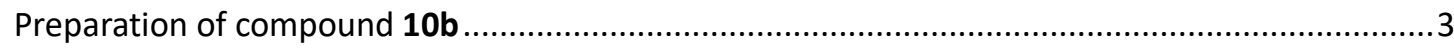

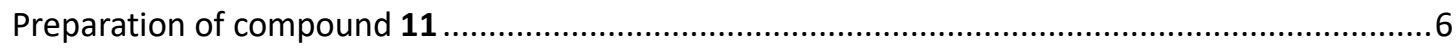

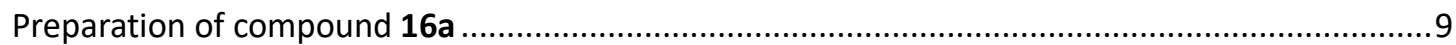

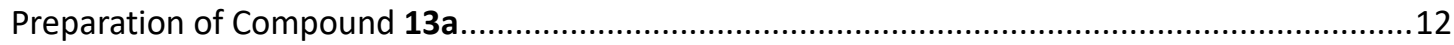

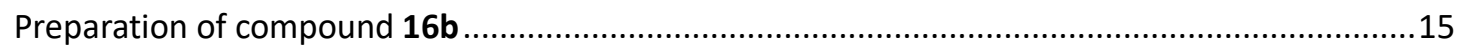

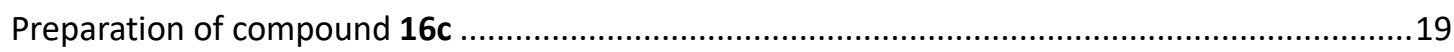

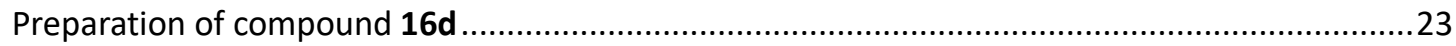

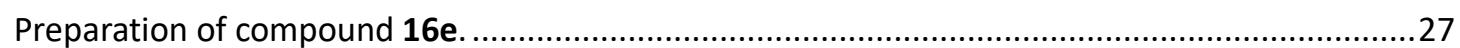

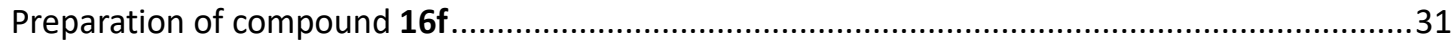

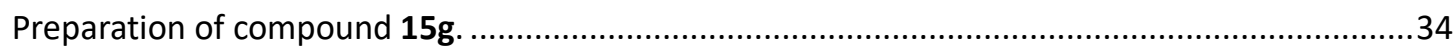

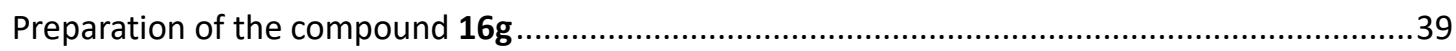

Preparation of azaborolyl potassium 17 (in situ reaction) ...................................................43

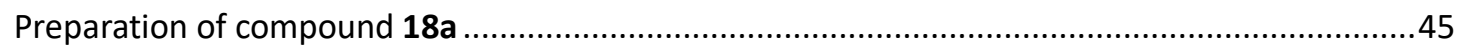

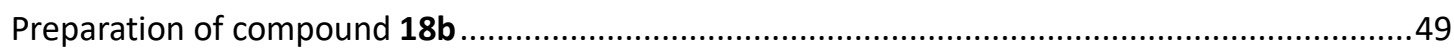

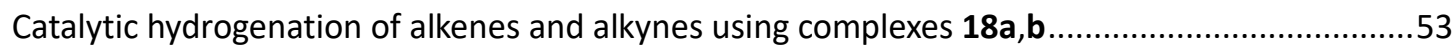

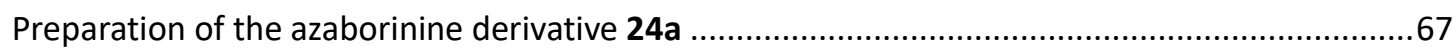

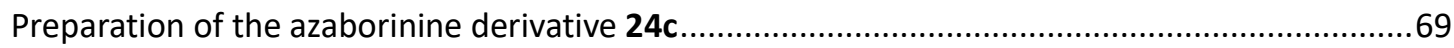

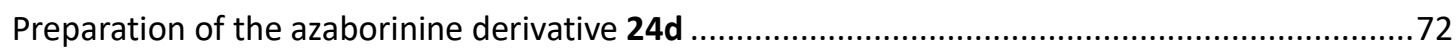

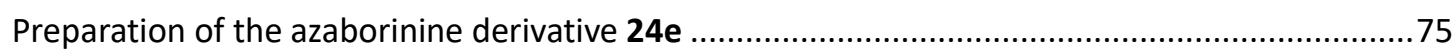

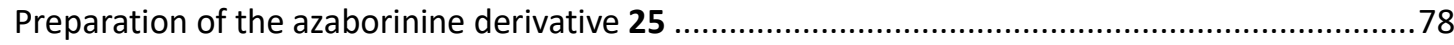

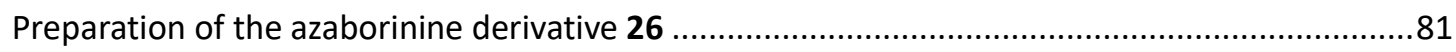

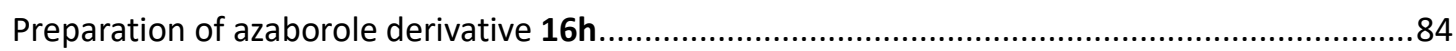

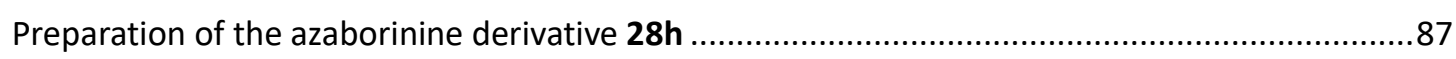

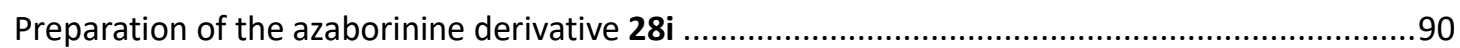

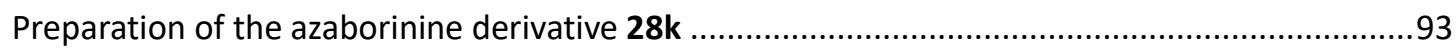

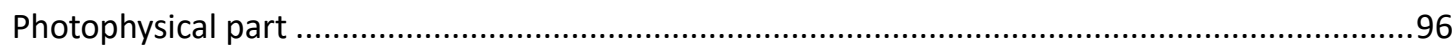

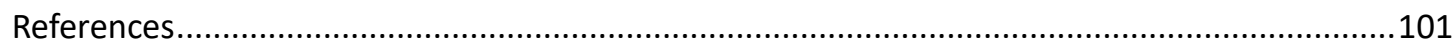




\section{Experimental Procedures}

General Information. All reactions involving air- or moisture-sensitive compounds were carried out under an inert gas atmosphere (argon) by using Schlenk-type glassware or in a glovebox. All solvents were dried and degassed before use, if necessary, for the respective reaction. Chemicals: Unless otherwise noted all chemicals were used as purchased. The following instruments were used for physical characterization of the compounds: elemental analyses: Foss-Heraeus CHNORapid; HRMS: Thermo Scientific Orbitrap LTQ XL; NMR: Varian UNITY plus NMR spectrometer $\left({ }^{1} \mathrm{H}\right.$, $\left.600 \mathrm{MHz} ;{ }^{13} \mathrm{C}, 151 \mathrm{MHz} ;{ }^{11} \mathrm{~B}, 192 \mathrm{MHz} ;{ }^{19} \mathrm{~F}, 564 \mathrm{MHz}\right)$. NMR chemical shifts are given relative to $\mathrm{SiMe}_{4}$ and referenced to the respective solvent signal $\left({ }^{1} \mathrm{H}\right.$ and $\left.{ }^{13} \mathrm{C}\right)$ or an external standard $\left[\delta\left(\mathrm{BF}_{3} \cdot \mathrm{OEt}_{2}\right)=0\right.$ for ${ }^{11} \mathrm{~B} \mathrm{NMR}, \delta\left(\mathrm{CFCl}_{3}\right)=0$ for ${ }^{19} \mathrm{~F} \mathrm{NMR}$. NMR assignments were supported by $2 \mathrm{D}$ NMR experiments.

X-Ray diffraction: Data sets for compounds 13a, 16e, 16f, 16g, 18b, 24d, 25, 26 and 28h were collected with a Bruker D8 Venture CMOS diffractometer. For compounds $10 \mathrm{~b}, \mathbf{1 1}, \mathbf{1 5 g}, \mathbf{1 6 b}, \mathbf{1 6 h}$,

18a, 24c, 24e, 28i and 28k data sets were collected with a Bruker APEX II CCD diffractometer. Programs used: data collection: APEX3 V2016.1-0 (Bruker AXS Inc., 2016); cell refinement: SAINT V8.37A (Bruker AXS Inc., 2015); data reduction: SAINT V8.37A (Bruker AXS Inc., 2015); absorption correction, SADABS V2014/7 (Bruker AXS Inc., 2014); structure solution SHELXT-2015 (Sheldrick, G. M. Acta Cryst., 2015, A71, 3-8); structure refinement SHELXL-2015 (Sheldrick, G. M. Acta Cryst., 2015, C71 (1), 3-8). For compounds 16c, 16d and 24a data sets were collected with a Nonius Kappa CCD diffractometer. Programs used: data collection, COLLECT (R. W. W. Hooft, Bruker AXS, 2008, Delft, The Netherlands); data reduction Denzo-SMN (Z. Otwinowski, W. Minor, Methods Enzymol. 1997, 276, 307-326); absorption correction, Denzo (Z. Otwinowski, D. Borek, W. Majewski, W. Minor, Acta Crystallogr. 2003, A59, 228-234); structure solution SHELXT-2015 (Sheldrick, G. M. Acta Cryst., 2015, A71, 3-8); structure refinement SHELXL-2015 (Sheldrick, G. M. Acta Cryst., 2015, C71 (1), 3-8) and graphics, XP (Version 5.1, Bruker AXS Inc., Madison, Wisconsin, USA, 1998). $R$-values are given for observed reflections, and $w R^{2}$ values are given for all reflections. Exceptions and special features: For compounds 11 and $\mathbf{2 8}$ i two $\mathrm{CF}_{3}$ groups, for compounds 13 a and 16 e four $\mathrm{CF}_{3}$ groups, for compound $\mathbf{1 6 h}$ three $\mathrm{CF}_{3}$ groups, for compound $\mathbf{1 5 g}$ two $\mathrm{CF}_{3}$ groups, the $\mathrm{P}(\mathrm{Mes})_{2}$ unit and one pentane molecule, for compounds 16b, 24a, 24c, 24d and 28k one $\mathrm{CF}_{3}$ group, for compound $16 \mathrm{c}$ two $\mathrm{CF}_{3}$ groups, for compound $16 \mathrm{~d}$ one ethyl group and two $\mathrm{CF}_{3}$ groups, for compound $24 \mathrm{e}$ one pentane molecule were found disordered over two positions in the asymmetric unit. For compound $\mathbf{2 8}$ h one $\mathrm{CF}_{3}$ group was found disordered over three positions in the asymmetrical unit. Several restraints (SADI, SAME, ISOR and SIMU) were used in order to improve refinement stability. Additionally, compound 16e was refined as a 2-component twin, whereby the BASF factor was refined to 0.40 . For compound $\mathbf{1 6 d}$ a badly disordered half pentane molecule, for compound $\mathbf{2 4 c}$ a badly disordered pentane molecule, for compound $\mathbf{2 8} \mathrm{h}$ two half badly disordered cyclopentane molecules and for compound $\mathbf{1 1}$ one-third pentane molecule were found in the asymmetrical unit and could not be satisfactorily refined. The program SQUEEZE (Spek, A.L. (2015). Acta Cryst. C71, 9-18.) was therefore used to remove mathematically the effect of the solvents. The quoted formula and derived parameters are not included the squeezed solvent molecules.

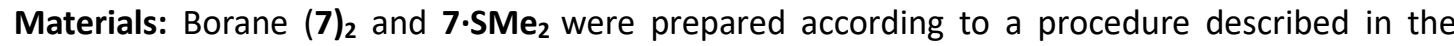
literature. ${ }^{8}$ Warning: Many isonitriles are toxic reagents, they should be used with due care. Organoalkalimetal compounds are strong bases and potentially ignite in contact with air and/or water. They should be used with due care. 
Numbering of the azaborinine ring for the assignment of NMR signals:

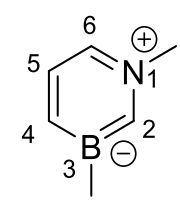

\section{Preparation of compound 10b}

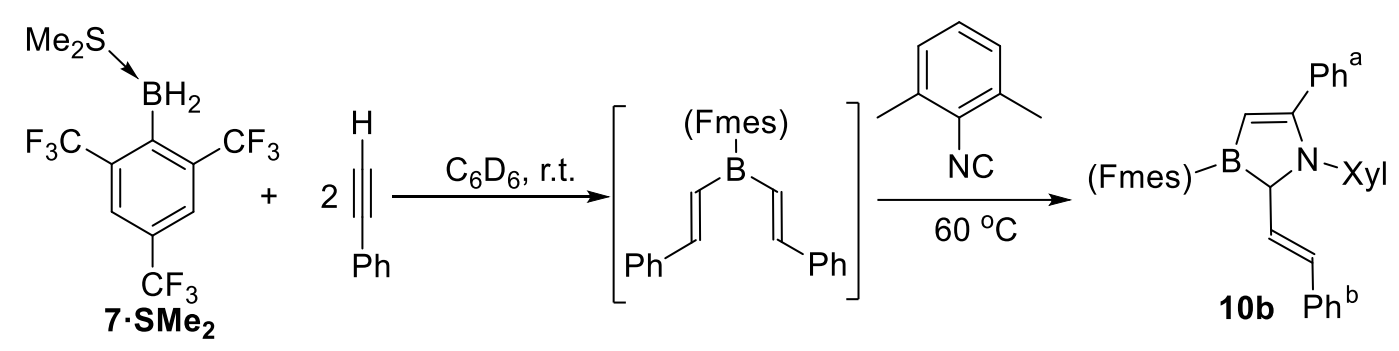

Scheme S1.

At room temperature, borane $7 \cdot \mathrm{SMe}_{2}(142.4 \mathrm{mg}, 0.4 \mathrm{mmol}, 1$ eq.) was added to the solution of phenyl acetylene ( $81.6 \mathrm{mg}, 0.8 \mathrm{mmol}, 2$ eq.) in $\mathrm{C}_{6} \mathrm{D}_{6}(2 \mathrm{~mL})$ under argon atmosphere in a Schlenk tube. Then the mixture was stirred for $30 \mathrm{~min}$ at room temperature to give a light-yellow solution. Subsequently 2,6-dimethylphenylisocyanide ( $52.4 \mathrm{mg}, 0.4 \mathrm{mmol}, 1 \mathrm{eq}$.) was added to the mixture in one portion to give a brown solution. The resulting solution was stirred at $60^{\circ} \mathrm{C}$ overnight. Then all volatiles were removed in vacuo, the residue was dissolved in heptane $(1 \mathrm{~mL})$ and stored at -35 ${ }^{\circ} \mathrm{C}$ to finally give the compound $10 \mathrm{~b}$ as a light yellow solid ( $174 \mathrm{mg}, 69 \%$ yield).

Elemental Analysis for $\mathrm{C}_{34} \mathrm{H}_{25} \mathrm{BNF}_{9}$ : calc. C (64.89\%), H (4.00\%), N (2.23\%); found: C (63.99\%), H (3.86\%), N (2.05\%);

HRMS for $\mathrm{C}_{34} \mathrm{H}_{24} \mathrm{BNF}_{9}{ }^{+}[\mathrm{M}-\mathrm{H}]^{+}$: calc. 628.1859 , found: 628.1857 .

${ }^{1} \mathrm{H}$ NMR $\left(600 \mathrm{MHz}\right.$, methylene chloride- $\left.d_{2}, 299 \mathrm{~K}\right): \delta=8.14$ (s, $1 \mathrm{H}, m$-Fmes), 8.09 (s, $1 \mathrm{H}, m^{\prime}$-Fmes), $7.39\left(\mathrm{~m}, 2 \mathrm{H}, o-\mathrm{Ph}^{\mathrm{a}}\right), 7.33\left(\mathrm{~m}, 1 \mathrm{H}, p-\mathrm{Ph}^{\mathrm{a}}\right), 7.26\left(\mathrm{~m}, 2 \mathrm{H}, m-\mathrm{Ph}^{\mathrm{a}}\right), 7.19\left(\mathrm{~m}, 2 \mathrm{H}, m-\mathrm{Ph}^{\mathrm{b}}\right), 7.11(\mathrm{~m}, 3 \mathrm{H}, o-$ $\left.\mathrm{Ph}^{\mathrm{b}}, p-\mathrm{Ph}^{\mathrm{b}}\right), 7.05(\mathrm{~m}, 2 \mathrm{H}, m-\mathrm{Xyl}, p-\mathrm{Xyl}), 6.91\left(\mathrm{dd},{ }^{3} J_{\mathrm{HH}}=6.5 \mathrm{~Hz},{ }^{4} J_{\mathrm{HH}}=2.6 \mathrm{~Hz}, 1 \mathrm{H}, m^{\prime}-\mathrm{Xyl}\right), 6.20(\mathrm{AB}$, $\left.{ }^{3} J_{\mathrm{HH}}=15.6 \mathrm{~Hz}, 1 \mathrm{H}, \mathrm{Ph}{ }^{\mathrm{b}} \mathrm{CH}=\right), 6.12\left(\mathrm{ABM},{ }^{3} \int_{\mathrm{HH}}=15.6 \mathrm{~Hz},{ }^{3} \int_{\mathrm{HH}}=9.4 \mathrm{~Hz}, 1 \mathrm{H}, \mathrm{CH}=\right), 5.68(\mathrm{~s}, 1 \mathrm{H}, \mathrm{BCH}=)$, $4.80(\mathrm{~m}, 1 \mathrm{H}, \mathrm{NCH}), 2.33\left(\mathrm{~s}, 3 \mathrm{H}, o^{\prime}-\mathrm{CH}_{3}{ }^{\mathrm{Xy}}\right), 2.13\left(\mathrm{~s}, 3 \mathrm{H}, \mathrm{o}-\mathrm{CH}_{3}{ }^{\mathrm{Xyl}}\right)$.

${ }^{13} \mathrm{C}\left\{{ }^{1} \mathrm{H}\right\}$ NMR (151 MHz, methylene chloride- $d_{2}, 299 \mathrm{~K}$ ) [selected resonances]: $\delta=182.4$ (NC=), 145.2 (br, $i$-Fmes), 139.7 (i-Xyl), [137.37, 137.36] (o-Xyl, $\left.o^{\prime}-\mathrm{Xyl}\right), 137.3\left(i-\mathrm{Ph}^{\mathrm{b}}\right), 134.8\left(i-\mathrm{Ph}^{\mathrm{a}}\right), 134.5\left(\mathrm{q},{ }^{2} \jmath_{\mathrm{FC}}=\right.$ $31.0 \mathrm{~Hz}, o^{\prime}$-Fmes), 133.8 (q, $\left.{ }^{2} J_{\mathrm{FC}}=30.9 \mathrm{~Hz}, o-F m e s\right), 132.2$ (Ph $\left.{ }^{\mathrm{b} C H}=\right), 130.5$ ( $\mathrm{q},{ }^{2} J_{\mathrm{FC}}=34.2 \mathrm{~Hz}, p$-Fmes), $130.3\left(p-\mathrm{Ph}^{\mathrm{a}}\right), 129.0(m-\mathrm{Xyl}), 128.85\left(m^{\prime}-\mathrm{Xyl}\right), 128.78\left(m-\mathrm{Ph}^{\mathrm{b}}\right), 128.6\left(o-\mathrm{Ph}^{\mathrm{a}}\right), 128.4\left(m-\mathrm{Ph}^{\mathrm{a}}\right), 127.9$ $(p-\mathrm{Xyl}), 127.6\left(p-\mathrm{Ph}^{\mathrm{b}}\right), 126.3\left(o-\mathrm{Ph}^{\mathrm{b}}\right), 126.0$ (br, $m^{\prime}$-Fmes), 125.7 (br, $m$-Fmes), 124.6 (m, CH=), 109.3 (br, $\mathrm{BCH}=), 73.2(\mathrm{br}, \mathrm{NCH}), 19.2\left(o^{\prime}-\mathrm{CH}_{3}{ }^{\mathrm{X}}\right)$ ), $18.6\left(0-\mathrm{CH}_{3}{ }^{\mathrm{XYl}}\right)$.

${ }^{11} \mathrm{~B}\left\{{ }^{1} \mathrm{H}\right\}$ NMR $\left(192 \mathrm{MHz}\right.$, methylene chloride- $\left.d_{2}, 299 \mathrm{~K}\right): \delta=59.6\left(\mathrm{v}_{1 / 2} \approx 910 \mathrm{~Hz}\right)$.

${ }^{19} \mathrm{~F}$ NMR $\left(564 \mathrm{MHz}\right.$, methylene chloride- $\left.d_{2}, 299 \mathrm{~K}\right): \delta=[-56.7,-57.7]\left(\right.$ each s, each $\left.1 \mathrm{~F}, o-\mathrm{CF}_{3}\right),-63.5$ $\left(p-\mathrm{CF}_{3}\right)$. 


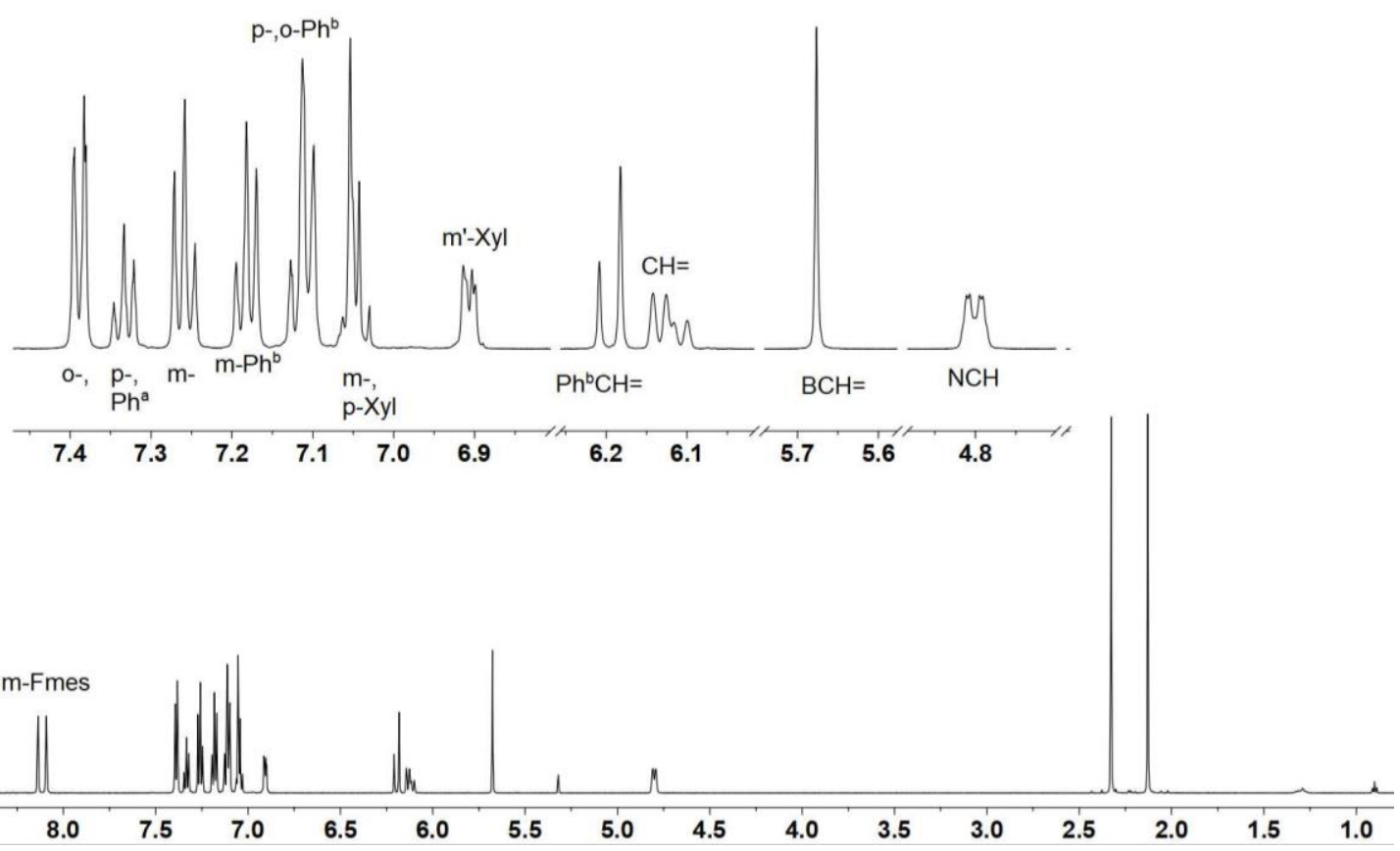

Figure S1. ${ }^{1} \mathrm{H}$ NMR (600 MHz, methylene chloride- $d_{2}, 299 \mathrm{~K}$ ) spectrum of compound $10 \mathrm{~b}$.

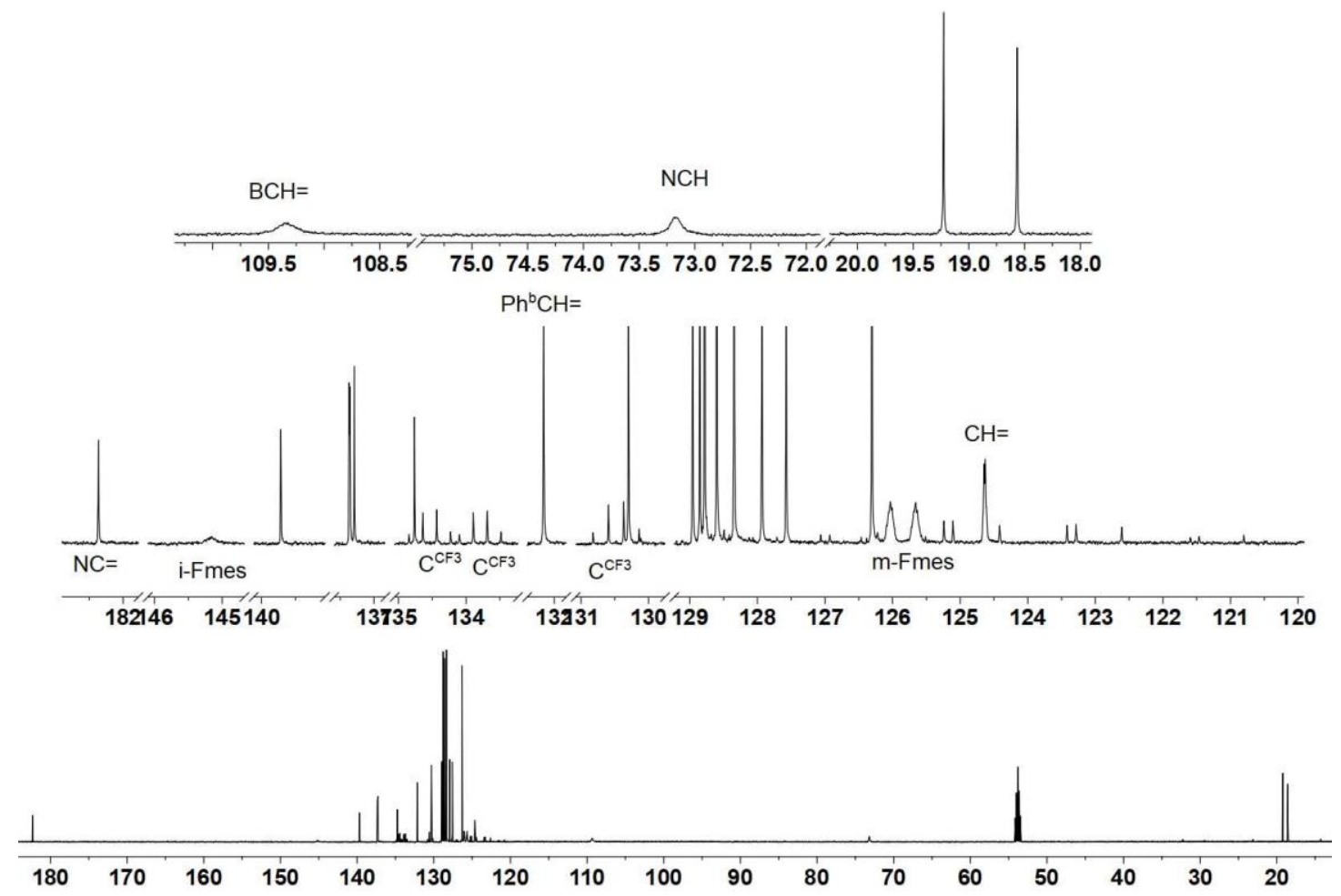

Figure S2. ${ }^{13} \mathrm{C}\left\{{ }^{1} \mathrm{H}\right\}$ NMR (151 MHz, methylene chloride- $\left.d_{2}, 299 \mathrm{~K}\right)$ spectrum of compound $10 \mathrm{~b}$. 


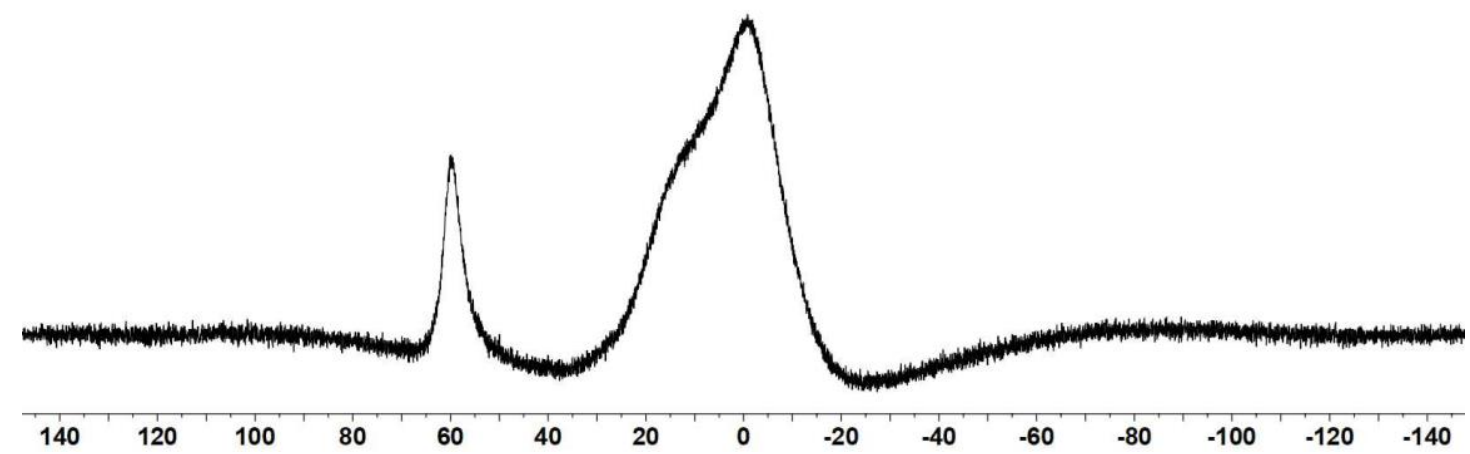

Figure S3. ${ }^{11} \mathrm{~B}\left\{{ }^{1} \mathrm{H}\right\}$ NMR (192 MHz, methylene chloride- $\left.d_{2}, 299 \mathrm{~K}\right)$ spectrum of compound $10 \mathrm{~b}$.

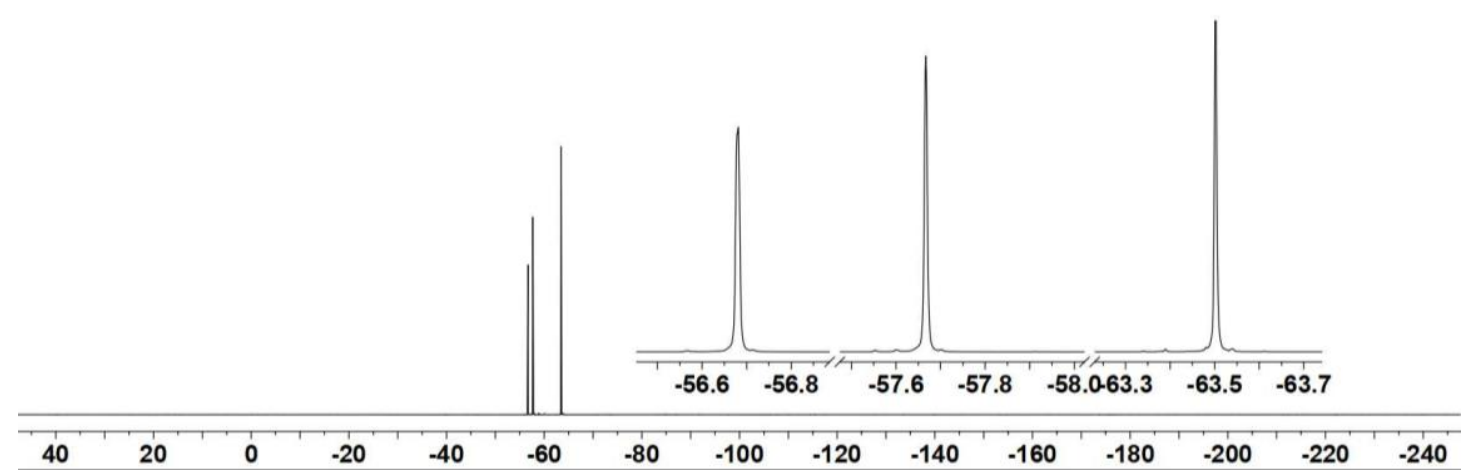

Figure S4. ${ }^{19} \mathrm{~F}$ NMR (564 MHz, methylene chloride, $299 \mathrm{~K}$ ) spectrum of compound 10b.

The single crystal suitable for the X-ray crystal structure analysis was obtained from a solution of compound $\mathbf{1 0 b}$ in heptane at room temperature.

X-ray crystal structure analysis of compound 10b (erk9655): A yellow prism-like specimen of $\mathrm{C}_{34} \mathrm{H}_{25} \mathrm{BF}_{9} \mathrm{~N}$, approximate dimensions $0.100 \mathrm{~mm} \times 0.140 \mathrm{~mm} \times 0.240 \mathrm{~mm}$, was used for the X-ray crystallographic analysis. The X-ray intensity data were measured. A total of 1459 frames were collected. The total exposure time was 19.84 hours. The frames were integrated with the Bruker SAINT software package using a wide-frame algorithm. The integration of the data using a monoclinic unit cell yielded a total of 39288 reflections to a maximum $\theta$ angle of $66.70^{\circ}(0.84 \AA$ resolution), of which 5166 were independent (average redundancy 7.605 , completeness $=99.8 \%$, $\left.\mathrm{R}_{\text {int }}=4.59 \%, \mathrm{R}_{\text {sig }}=2.51 \%\right)$ and $4456(86.26 \%)$ were greater than $2 \sigma\left(\mathrm{F}^{2}\right)$. The final cell constants of $\underline{\mathrm{a}}$ $=17.0933(3) \AA, \underline{b}=9.8292(2) \AA, \underline{c}=17.4543(3) \AA, \beta=95.4300(10)^{\circ}$, volume $=2919.40(9) \AA^{3}$, are based upon the refinement of the XYZ-centroids of 9899 reflections above $20 \sigma(I)$ with $6.918^{\circ}<2 \theta$ $<133.2^{\circ}$. Data were corrected for absorption effects using the multi-scan method (SADABS). The ratio of minimum to maximum apparent transmission was 0.868 . The calculated minimum and maximum transmission coefficients (based on crystal size) are 0.7840 and 0.9010 . The structure was solved and refined using the Bruker SHELXTL Software Package, using the space group $P 2{ }_{1} / n$, with $\mathrm{Z}=4$ for the formula unit, $\mathrm{C}_{34} \mathrm{H}_{25} \mathrm{BF} 9 \mathrm{~N}$. The final anisotropic full-matrix least-squares refinement on $\mathrm{F}^{2}$ with 408 variables converged at $\mathrm{R} 1=3.76 \%$, for the observed data and $\mathrm{WR2}=$ $10.45 \%$ for all data. The goodness-of-fit was 1.041. The largest peak in the final difference electron density synthesis was $0.244 \mathrm{e}^{-} / \AA^{3}$ and the largest hole was $-0.239 \mathrm{e}-/ \AA^{3}$ with an RMS deviation of $0.045 \mathrm{e}^{-} / \AA^{3}$. On the basis of the final model, the calculated density was $1.432 \mathrm{~g} / \mathrm{cm}^{3}$ and $F(000)$, 1288 e. CCDC number: 2007631. 


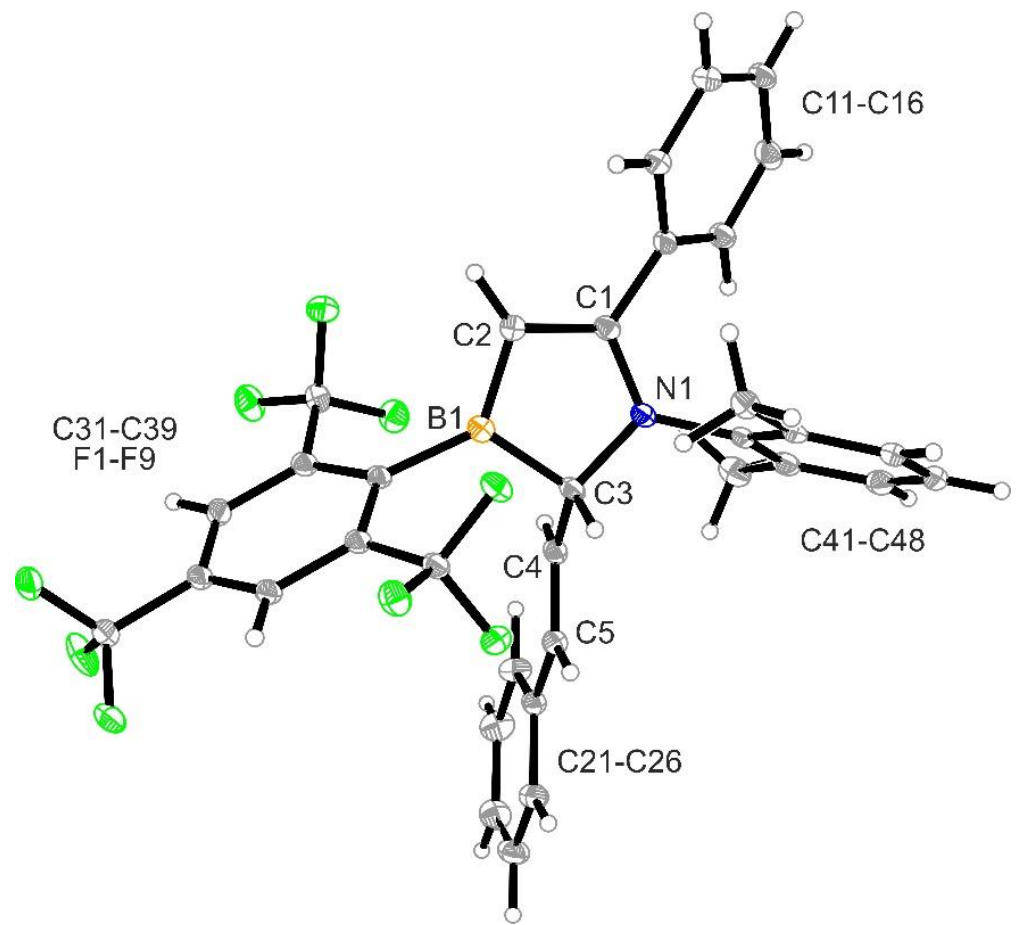

Figure S5. Crystal structure of compound 10b (thermal ellipsoids at 30\% probability).

\section{Preparation of compound 11}<smiles>[Y14]N1CB(CC(F)F)C(C=Cc2ccccc2)=C1c1ccccc1</smiles>

Scheme S2.

At room temperature, azaborole $10 \mathrm{~b}(94.3 \mathrm{mg}, 1.5 \mathrm{mmol})$ was dissolved in toluene $(2 \mathrm{~mL})$ under argon atmosphere in a J. Young tube. The resulting solution was stored at $110^{\circ} \mathrm{C}$ for 7 days. Then all volatiles were removed in vacuo. Subsequently, the residue was dissolved in pentane $(1 \mathrm{~mL})$ and stored at $-35{ }^{\circ} \mathrm{C}$ to finally give the compound 11 as a yellow solid ( $80 \mathrm{mg}, 85 \%$ yield).

HRMS for $\mathrm{C}_{34} \mathrm{H}_{26} \mathrm{BNF}_{9}{ }^{+},[\mathrm{M}+\mathrm{H}]^{+}$: calc. 630.2015; found: 630.2019 .

${ }^{1} \mathrm{H}$ NMR $\left(600 \mathrm{MHz}\right.$, methylene chloride- $\left.d_{2}, 299 \mathrm{~K}\right): \delta=8.24$ (s, $2 \mathrm{H}, m$-Fmes), $7.34(\mathrm{~m}, 5 \mathrm{H}, o-, m-, p-$ $\left.\mathrm{Ph}^{\mathrm{a}}\right), 7.11\left(\mathrm{~m}, 2 \mathrm{H}, m-\mathrm{Ph}^{\mathrm{b}}\right), 7.06(\mathrm{~m}, 1 \mathrm{H}, p-\mathrm{Xyl}), 7.00\left(\mathrm{~m}, 3 \mathrm{H}, p-\mathrm{Ph}^{\mathrm{b}}, m-\mathrm{Xyl}\right), 6.95\left(\mathrm{~m}, 2 \mathrm{H}, o-\mathrm{Ph}^{\mathrm{b}}\right), 6.74$ $\left(\mathrm{d},{ }^{3} \mathrm{~J}_{\mathrm{HH}}=16.1 \mathrm{~Hz}, 1 \mathrm{H}, \mathrm{CH}=\right), 5.78\left(\mathrm{~d},{ }^{3} \mathrm{HH}_{\mathrm{HH}}=16.1 \mathrm{~Hz}, 1 \mathrm{H}, \mathrm{Ph}{ }^{b} \mathrm{CH}=\right), 3.78\left(\mathrm{~m}, 2 \mathrm{H}, \mathrm{CH}_{2}\right), 2.20\left(\mathrm{~s}, 6 \mathrm{H}, o^{-}\right.$ $\left.\mathrm{CH}_{3}{ }^{\mathrm{Xy}}\right)$.

${ }^{13} \mathrm{C}\left\{{ }^{1} \mathrm{H}\right\}$ NMR (151 MHz, methylene chloride- $d_{2}, 299 \mathrm{~K}$ ) [selected resonances]: $\delta=179.9$ (NC=), 146.2 (br, i-Fmes), 140.9 (i-Xyl), $139.7\left(i-\mathrm{Ph}^{\mathrm{b}}\right), 136.9$ (o-Xyl), 133.8 (q, $\left.{ }^{2} \mathrm{FFC}_{\mathrm{FC}}=31.4 \mathrm{~Hz}, o-\mathrm{Fmes}\right), 132.8\left(i-\mathrm{Ph}^{\mathrm{a}}\right)$, $130.8\left(q,{ }^{2} \mathrm{JFC}_{\mathrm{FC}}=34.3 \mathrm{~Hz}, m\right.$-Fmes), $129.9\left(p-\mathrm{Ph}^{\mathrm{a}}\right), 129.2\left(m-\mathrm{Ph}^{\mathrm{a}}\right), 128.7(m-\mathrm{Xyl}), 128.6\left(m-\mathrm{Ph}^{\mathrm{b}}\right), 128.3$ $\left(o-\mathrm{Ph}^{\mathrm{a}}\right), 128.1$ ( $\left.p-\mathrm{Xyl}\right), 126.8(\mathrm{CH}=), 126.3(\mathrm{br}, m-\mathrm{Fmes}), 125.9\left(p-\mathrm{Ph}^{\mathrm{b}}\right), 125.4\left(o-\mathrm{Ph}^{\mathrm{b}}\right), 124.8\left(\mathrm{Ph}^{\mathrm{b}} \mathrm{CH}=\right)$, 119.1 (br, BC=), $56.9\left(\mathrm{CH}_{2}\right), 17.9\left(0-\mathrm{CH}_{3}{ }^{\mathrm{Xy}}\right)$.

${ }^{11} \mathrm{~B}\left\{{ }^{1} \mathrm{H}\right\}$ NMR $\left(192 \mathrm{MHz}\right.$, methylene chloride- $\left.d_{2}, 299 \mathrm{~K}\right): \delta=59.8\left(\mathrm{v}_{1 / 2} \approx 1010 \mathrm{~Hz}\right)$.

${ }^{19} \mathrm{~F} \mathrm{NMR}\left(564 \mathrm{MHz}\right.$, methylene chloride $\left.-d_{2}, 299 \mathrm{~K}\right): \delta=-59.1$ (s, 2F, o- $\left.\mathrm{CF}_{3}{ }^{\mathrm{Fmes}}\right),-63.4\left(\mathrm{~s}, 1 \mathrm{~F}, p-\mathrm{CF}_{3}{ }^{\mathrm{Fmes}}\right)$. 


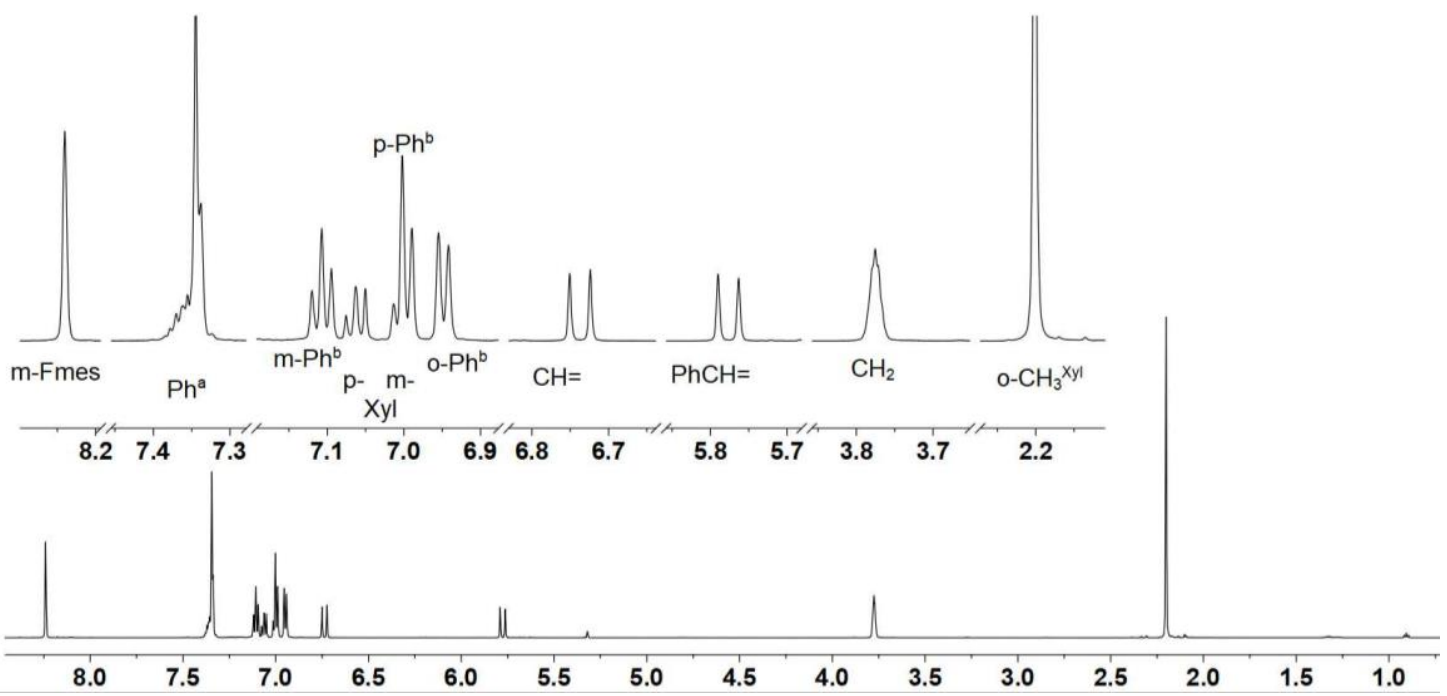

Figure S6. ${ }^{1} \mathrm{H}$ NMR (600 MHz, methylene chloride- $\left.d_{2}, 299 \mathrm{~K}\right)$ spectrum of compound 11.
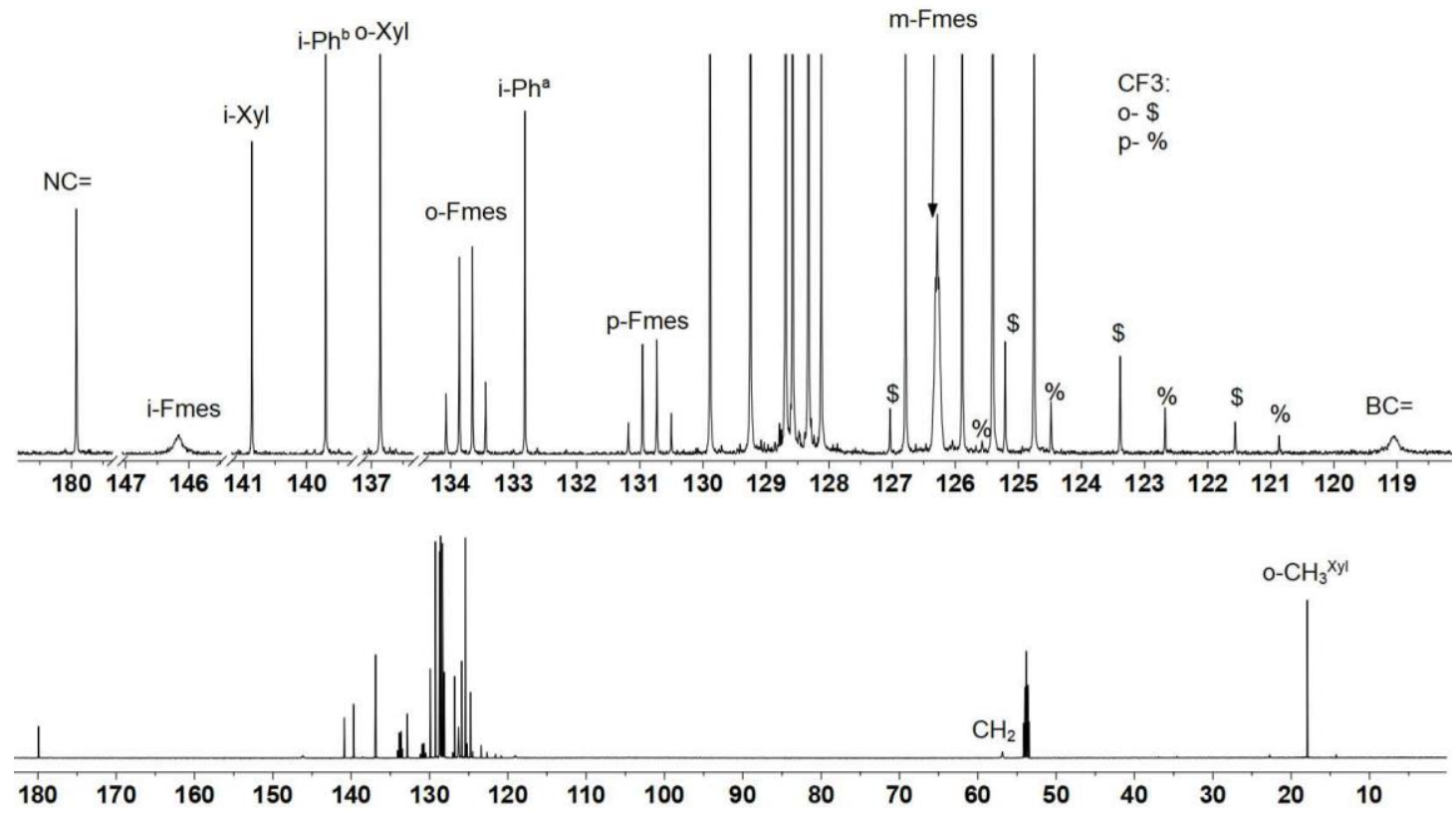

Figure S7. ${ }^{13} \mathrm{C}\left\{{ }^{1} \mathrm{H}\right\}$ NMR (151 MHz, methylene chloride- $\left.d_{2}, 299 \mathrm{~K}\right)$ spectrum of compound 11.

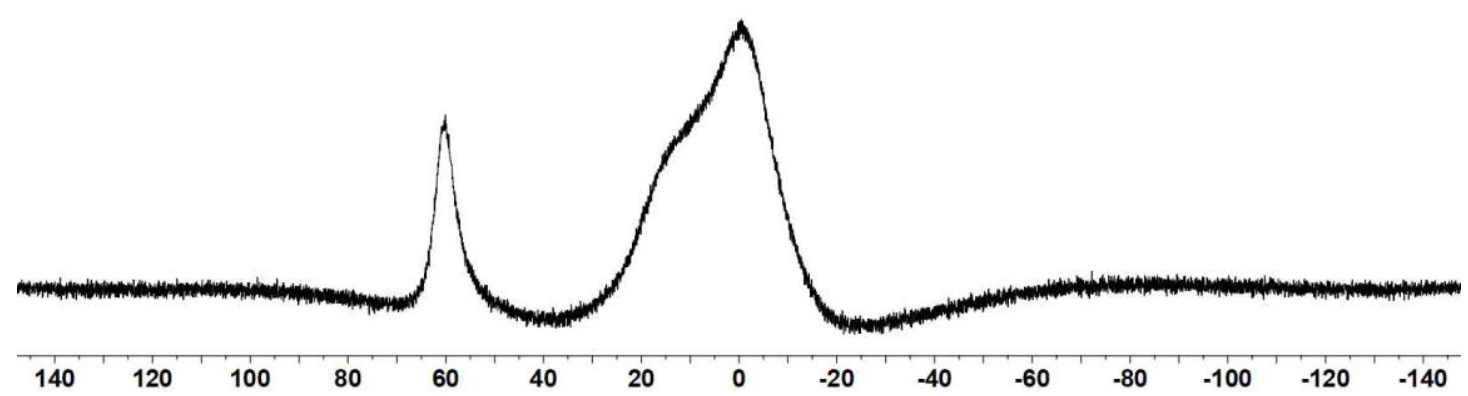

Figure S8. ${ }^{11} \mathrm{~B}\left\{{ }^{1} \mathrm{H}\right\}$ NMR (192 MHz, methylene chloride- $d_{2}, 299 \mathrm{~K}$ ) spectrum of compound 11. 


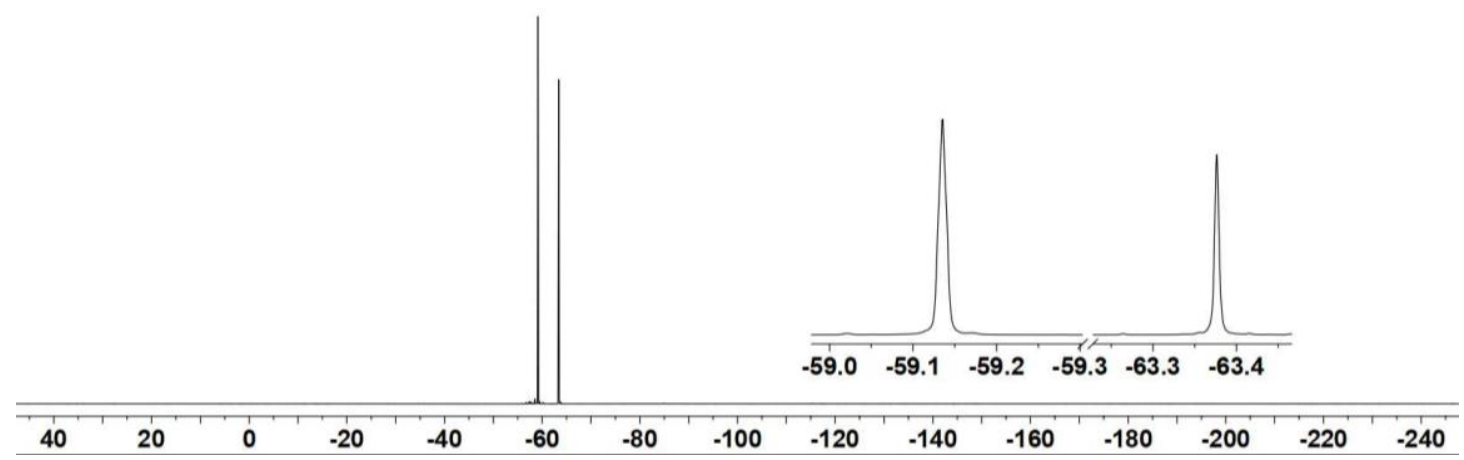

Figure S9. ${ }^{19} \mathrm{~F}$ NMR (564 MHz, methylene chloride, $299 \mathrm{~K}$ ) spectrum of compound $\mathbf{1 1 .}$

Single crystals suitable for the X-ray crystal structure analysis were obtained from a solution of compound 10 in pentane at $-35^{\circ} \mathrm{C}$.

X-ray crystal structure analysis of compound 11 (erk9620): A pale yellow prism-like specimen of $\mathrm{C}_{34} \mathrm{H}_{25} \mathrm{BF} 9 \mathrm{~N}$, approximate dimensions $0.100 \mathrm{~mm} \times 0.120 \mathrm{~mm} \times 0.150 \mathrm{~mm}$, was used for the X-ray crystallographic analysis. The X-ray intensity data were measured. A total of 2029 frames were collected. The total exposure time was 21.96 hours. The frames were integrated with the Bruker SAINT software package using a wide-frame algorithm. The integration of the data using a trigonal unit cell yielded a total of 62150 reflections to a maximum $\theta$ angle of $65.06^{\circ}$ ( $0.85 \AA$ resolution), of which 5164 were independent (average redundancy 12.035 , completeness $=99.8 \%, R_{\text {int }}=13.49 \%$, $\left.R_{\text {sig }}=6.73 \%\right)$ and $3665(70.97 \%)$ were greater than $2 \sigma\left(F^{2}\right)$. The final cell constants of $\underline{a}=34.991(3)$ $\AA, \underline{b}=34.991(3) \AA, \underline{c}=12.8827(10) \AA$, volume $=13660$. (2) $\AA^{3}$, are based upon the refinement of the $X Y Z$-centroids of 4849 reflections above $20 \sigma(I)$ with $8.754^{\circ}<2 \theta<130.5^{\circ}$. Data were corrected for absorption effects using the multi-scan method (SADABS). The ratio of minimum to maximum apparent transmission was 0.779 . The calculated minimum and maximum transmission coefficients (based on crystal size) are 0.8620 and 0.9050 . The structure was solved and refined using the Bruker SHELXTL Software Package, using the space group $R-3$, with $Z=18$ for the formula unit, $\mathrm{C}_{34} \mathrm{H}_{25} \mathrm{BF} 9 \mathrm{~N}$. The final anisotropic full-matrix least-squares refinement on $\mathrm{F}^{2}$ with 465 variables converged at $R 1=5.28 \%$, for the observed data and $w R 2=14.18 \%$ for all data. The goodness-of-fit was 1.040. The largest peak in the final difference electron density synthesis was $0.280 \mathrm{e}^{-} / \AA^{3}$ and the largest hole was $-0.244 \mathrm{e}^{-} / \AA^{3}$ with an RMS deviation of $0.064 \mathrm{e}^{-} / \AA^{3}$. On the basis of the final model, the calculated density was $1.377 \mathrm{~g} / \mathrm{cm}^{3}$ and F(000), $5796 \mathrm{e}-$. CCDC number: 2007632. 


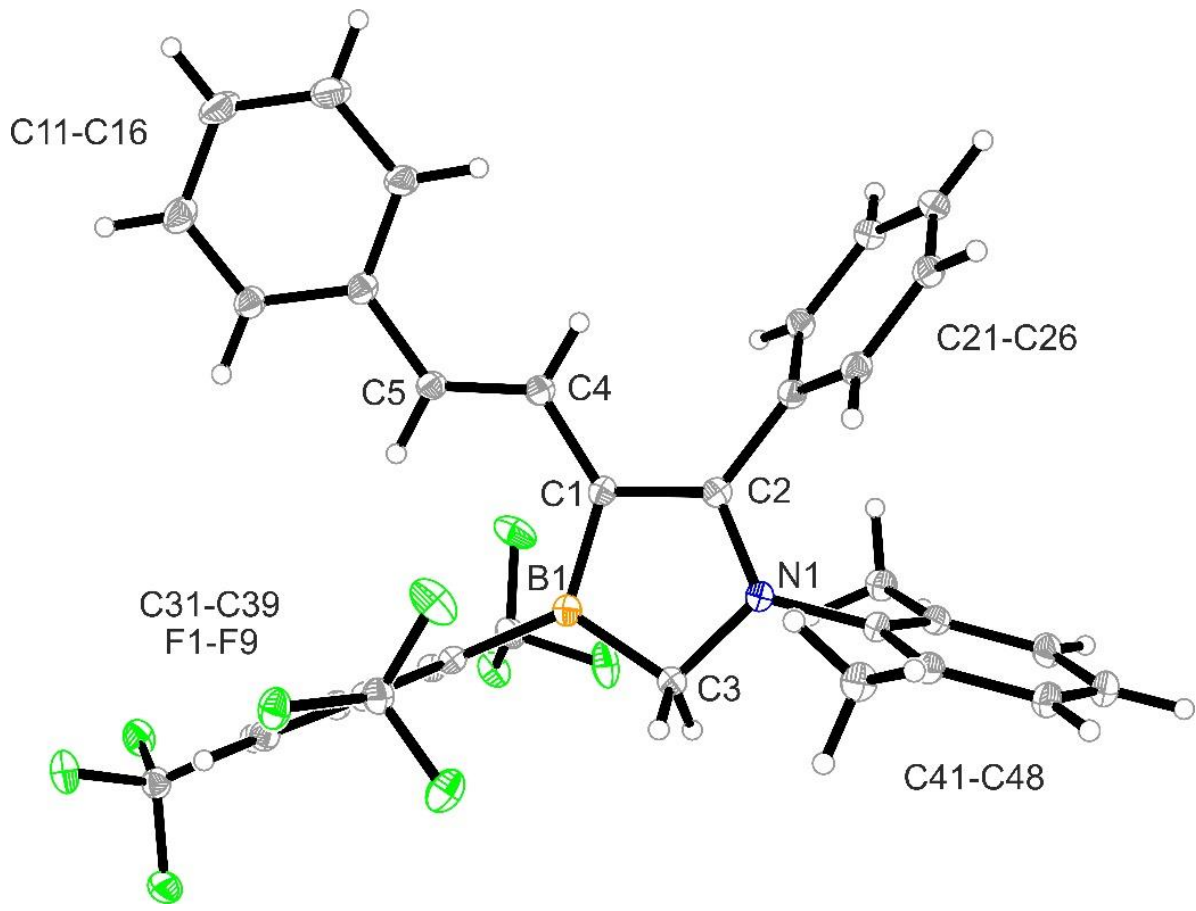

Figure S10. Crystal structure of compound $\mathbf{1 1}$ (thermal ellipsoids at 15\% probability).

\section{Preparation of compound 16a}

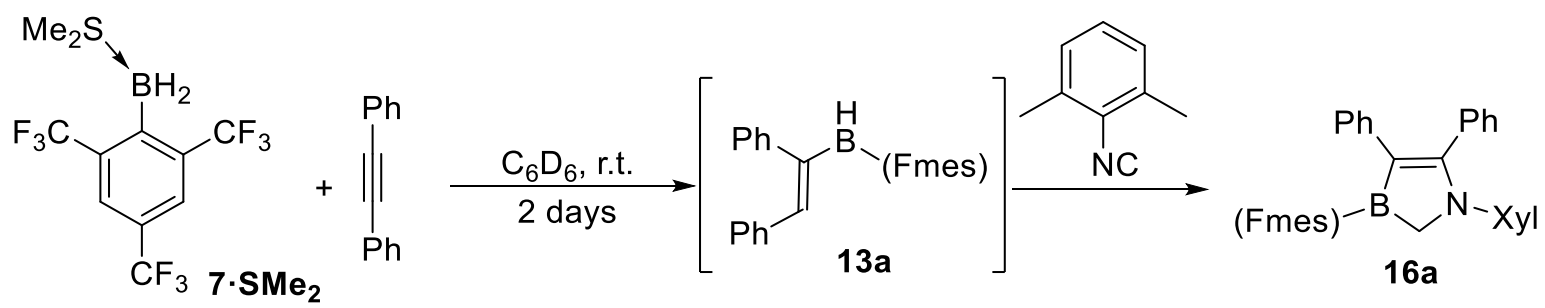

Scheme S3.

Experiment 1:

At room temperature, borane $\mathbf{7} \cdot \mathrm{SMe}_{2}(71.2 \mathrm{mg}, 0.2 \mathrm{mmol}, 1$ equiv.) was added to a solution of diphenylacetylene ( $35.6 \mathrm{mg}, 0.2 \mathrm{mmol}, 1$ equiv.) in $\mathrm{C}_{6} \mathrm{D}_{6}(1 \mathrm{~mL})$ under argon atmosphere in a J. Young tube. Then the mixture was stored for 2 days at room temperature to give a light orange solution. The formation of the hydroboration product was monitored by an in situ NMR experiment. Then 2,6-dimethylphenylisocyanide ( $26.2 \mathrm{mg}, 0.2 \mathrm{mmol}, 1$ equiv.) was added to the mixture in one portion to give a brown solution. The resulting solution was stored at $60^{\circ} \mathrm{C}$ for $5 \mathrm{~h}$. Then all volatiles were removed in vacuo, the residue was dissolved in pentane $(1 \mathrm{~mL})$ and stored at $-35^{\circ} \mathrm{C}$ to finally give the product 16a as a light-yellow solid (95 mg, $77 \%$ yield). 
Experiment 2 (large scale reaction):

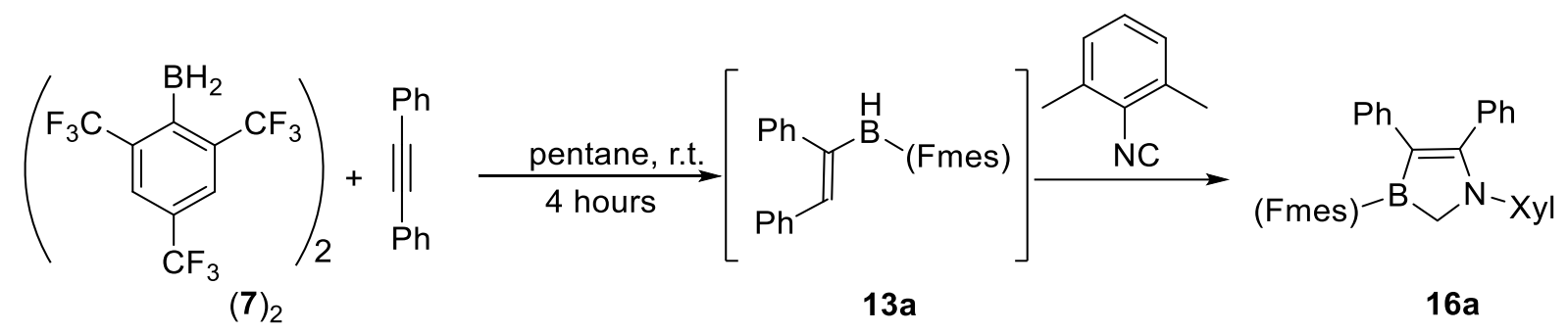

\section{Scheme S4.}

In a Schlenk tube, borane (7) 2 (588 mg, $2 \mathrm{mmol}, 1$ equiv.) and diphenylacetylene ( $356 \mathrm{mg}, 2 \mathrm{mmol}$, 1 equiv.) was added subsequently to pentane ( $15 \mathrm{~mL}$ ). The suspension was stirred for 4 hours at room temperature to give a clear solution. Then 2,6-dimethylphenylisocyanide $(262 \mathrm{mg}, 2 \mathrm{mmol}$, 1 equiv.) was added and the resulting mixture was stirred at room temperature for 2 days to give a red solution. Volatiles were removed in vacuo and the residue was purified by column chromatography on silica gel with pentane : dichloromethane (20:1) as the eluent to finally give compound 16a as a light-yellow solid (1.12 g, 93\% yield).

Elemental Analysis for $\mathrm{C}_{32} \mathrm{H}_{23} \mathrm{BF} 9 \mathrm{~N}$ : calc. $\mathrm{C}(63.70 \%), \mathrm{H}(3.84 \%), \mathrm{N}(2.32 \%)$; found: $\mathrm{C}(63.71 \%), \mathrm{H}$ (3.86\%), N (2.28\%).

${ }^{1} \mathrm{H}$ NMR (600 MHz, methylene chloride- $\left.d_{2}, 299 \mathrm{~K}\right): \delta=8.10\left(\mathrm{~s}, 2 \mathrm{H}, m\right.$-Fmes), $7.20\left(\mathrm{~m}, 1 \mathrm{H}, p-\mathrm{Ph}^{\mathrm{N}}\right)$, $7.12\left(\mathrm{~m}, 2 \mathrm{H}, m-\mathrm{Ph}^{\mathrm{N}}\right), 7.11\left(\mathrm{~m}, 2 \mathrm{H}, o-\mathrm{Ph}^{\mathrm{N}}\right), 7.05(\mathrm{~m}, 1 \mathrm{H}, p-\mathrm{Xyl}), 6.99(\mathrm{~m}, 2 \mathrm{H}, m-\mathrm{Xyl}), 6.91(\mathrm{~m}, 2 \mathrm{H}, m-$ $\left.\mathrm{Ph}^{\mathrm{B}}\right), 6.86\left(\mathrm{~m}, 1 \mathrm{H}, p-\mathrm{Ph}^{\mathrm{B}}\right), 6.71\left(\mathrm{~m}, 2 \mathrm{H}, \mathrm{o}-\mathrm{Ph}^{\mathrm{B}}\right), 3.80$ (sept., $\left.\mathrm{JFH}_{\mathrm{FH}}=2.6 \mathrm{~Hz}, 2 \mathrm{H}, \mathrm{CH}_{2}\right), 2.21\left(\mathrm{~s}, 6 \mathrm{H}, \mathrm{o}-\mathrm{CH}_{3}{ }^{\mathrm{Xl}}\right)$. ${ }^{13} \mathrm{C}\left\{{ }^{1} \mathrm{H}\right\}$ NMR (151 MHz, methylene chloride- $\left.d_{2}, 299 \mathrm{~K}\right): \delta=179.2$ (NC=), 145.5 (br, i-Fmes), 141.1 ( $i$ $\mathrm{Xyl}), 140.2\left(i-\mathrm{Ph}^{\mathrm{B}}\right), 137.0(o-\mathrm{Xyl}), 134.0\left(\mathrm{q},{ }^{2} J_{\mathrm{FC}}=31.1 \mathrm{~Hz}, o-\mathrm{Fmes}\right), 133.5\left(i-\mathrm{Ph}^{\mathrm{N}}\right), 130.5\left(\mathrm{q},{ }^{2} J_{\mathrm{FC}}=34.2\right.$ $\mathrm{Hz}, p$-Fmes), $129.5\left(o-\mathrm{Ph}^{\mathrm{B}}, \mathrm{BC}=, o-\mathrm{Ph}^{\mathrm{N}}\right), 129.4\left(p-\mathrm{Ph}^{\mathrm{N}}\right), 128.6(m-\mathrm{Xyl}), 128.00(p-\mathrm{Xyl}), 127.95\left(m-\mathrm{Ph}^{\mathrm{N}}\right)$, $127.7\left(m-\mathrm{Ph}^{\mathrm{B}}\right), 126.0$ (br, $m$-Fmes), $124.2\left(\mathrm{q},{ }^{1} \mathrm{JFC}_{\mathrm{FC}}=274 \mathrm{~Hz}, o-\mathrm{CF}_{3}{ }^{\mathrm{Fmes}}\right), 124.0\left(p-\mathrm{Ph}^{\mathrm{N}}\right), 123.5\left(\mathrm{q},{ }^{1} \mathrm{JFC}_{\mathrm{FC}}=\right.$ $\left.273 \mathrm{~Hz}, p-\mathrm{CF}_{3}{ }^{\text {Fmes }}\right), 56.7\left(\mathrm{br}, \mathrm{CH}_{2}\right), 18.0\left(o-\mathrm{CH}_{3}{ }^{\mathrm{Xyl}}\right)$.

${ }^{11} \mathbf{B}\left\{{ }^{1} \mathrm{H}\right\}$ NMR $\left(192 \mathrm{MHz}\right.$, methylene chloride- $\left.d_{2}, 299 \mathrm{~K}\right): \delta=59.3\left(\mathrm{v}_{1 / 2} \approx 770 \mathrm{~Hz}\right)$.

${ }^{19} \mathrm{~F} \mathrm{NMR}\left(564 \mathrm{MHz}\right.$, methylene chloride- $\left.\mathrm{d}_{2}, 299 \mathrm{~K}\right): \delta=-58.3\left(\mathrm{~m}, 2 \mathrm{~F}, o-\mathrm{CF}_{3}{ }^{\mathrm{Fmes}}\right),-63.5\left(\mathrm{~s}, 1 \mathrm{~F}, p-\mathrm{CF}_{3}{ }^{\mathrm{Fmes}}\right)$.

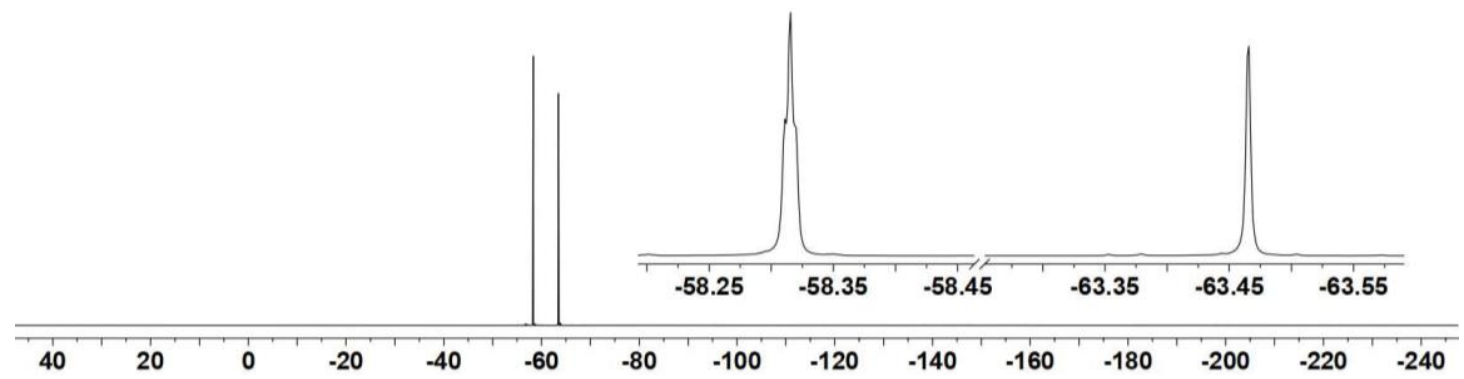

Figure S11. ${ }^{19} \mathrm{~F}$ NMR (564 MHz, methylene chloride, $299 \mathrm{~K}$ ) spectrum of compound 16a. 

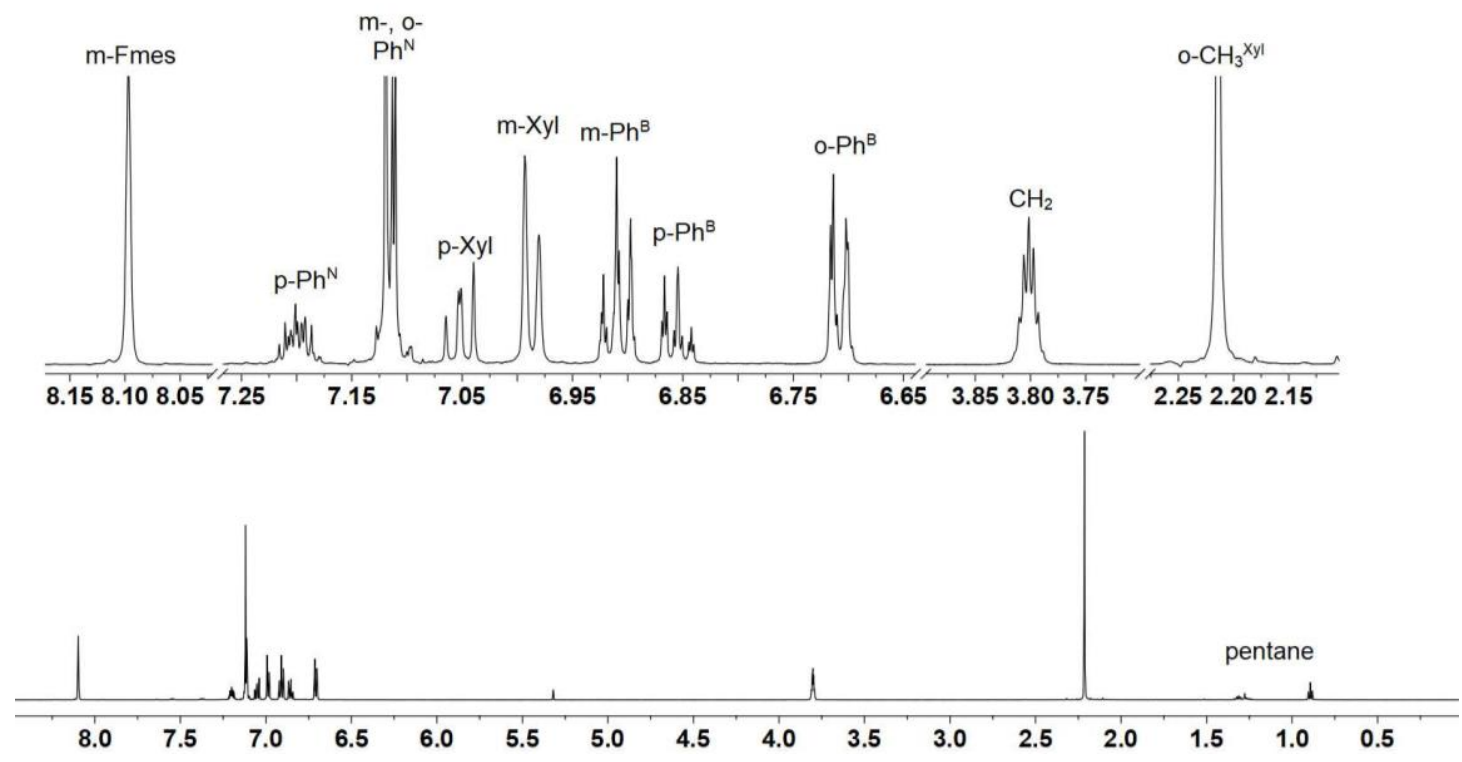

Figure S12. ${ }^{1} \mathrm{H}$ NMR (600 MHz, methylene chloride- $d_{2}, 299 \mathrm{~K}$ ) spectrum of compound 16a.

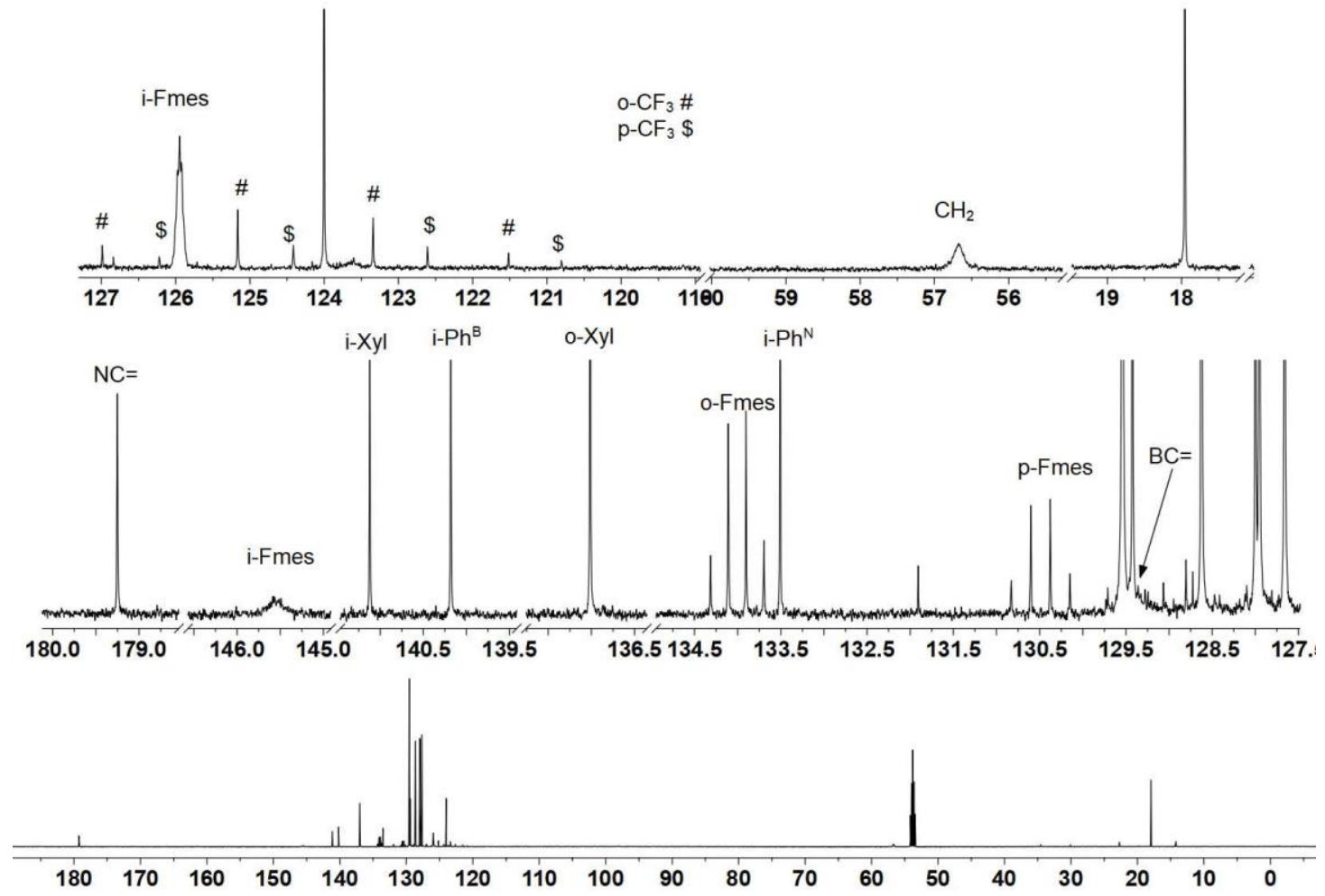

Figure S13. ${ }^{13} \mathrm{C}\left\{{ }^{1} \mathrm{H}\right\}$ NMR (151 MHz, methylene chloride- $\left.d_{2}, 299 \mathrm{~K}\right)$ spectrum of compound 16a. 


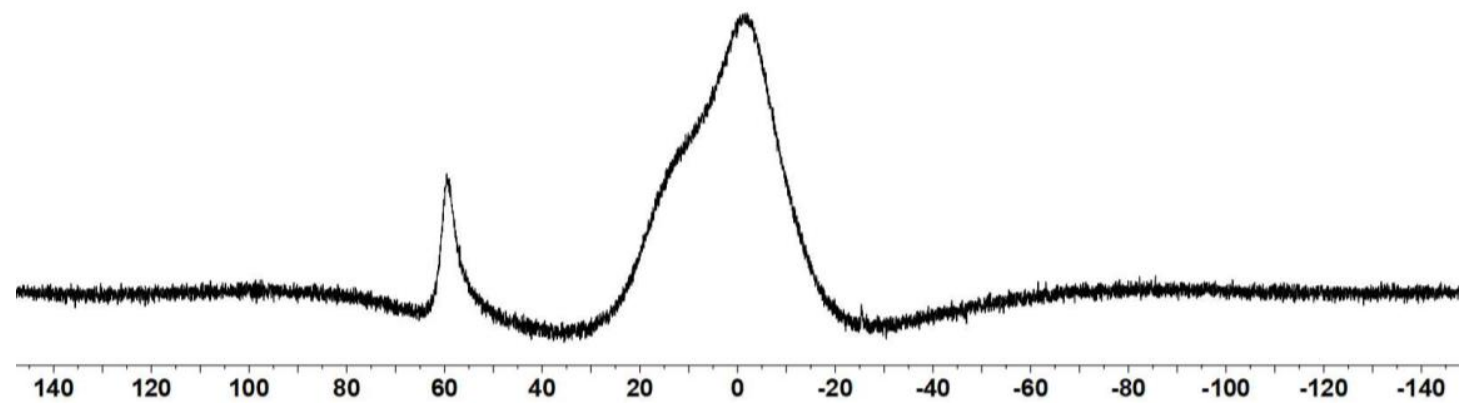

Figure S14. ${ }^{11} \mathrm{~B}\left\{{ }^{1} \mathrm{H}\right\}$ NMR (192 MHz, methylene chloride- $d_{2}, 299 \mathrm{~K}$ ) spectrum of compound $16 \mathrm{a}$.

\section{Preparation of Compound 13a}

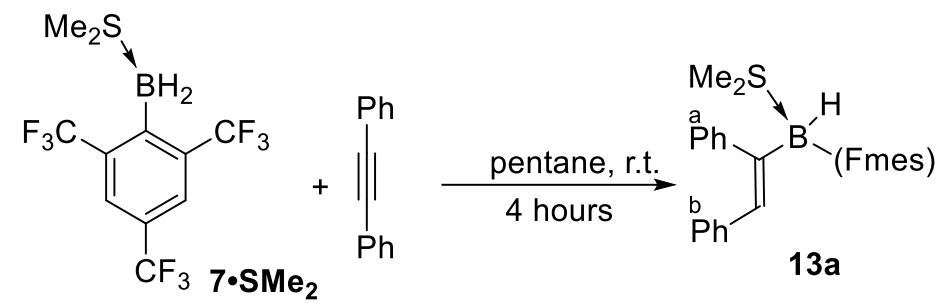

Scheme S5.

In a Schlenk tube, borane 7.SMe 2356 mg, 1 mmol, 1 equiv.) and diphenylacetylene (178 mg, 1 mmol, 1 equiv.) were added subsequently to pentane $(5 \mathrm{~mL})$. The suspension was stirred for 4 hours at room temperature to give a clear solution. Then the mixture was stored at $-35^{\circ} \mathrm{C}$ for 1 day to give compound $13 \mathrm{a}$ as a colorless crystalline solid ( $316 \mathrm{~g}, 59 \%$ yield).

Elemental Analysis for $\mathrm{C}_{25} \mathrm{H}_{20} \mathrm{BF}$ S: calc. C (56.20\%), $\mathrm{H}(3.77 \%)$; found: $\mathrm{C}$ (56.85 \%), H (3.29 \%).

${ }^{1} \mathrm{H}$ NMR (600 MHz, benzene- $\left.d_{6}, 299 \mathrm{~K}\right): \delta=7.79(\mathrm{~s}, 2 \mathrm{H}, m$-Fmes), $7.24(\mathrm{br}, 1 \mathrm{H}, \mathrm{CH}=), 7.15(\mathrm{~m}, 2 \mathrm{H}$, $\left.o-\mathrm{Ph}^{\mathrm{a}}\right), 7.04\left(\mathrm{~m}, 2 \mathrm{H}, m-\mathrm{Ph}^{\mathrm{a}}\right), 7.02\left(\mathrm{~m}, 2 \mathrm{H}, o-\mathrm{Ph}^{\mathrm{b}}\right), 6.95\left(\mathrm{~m}, 1 \mathrm{H}, p-\mathrm{Ph}^{\mathrm{a}}\right), 6.84\left(\mathrm{~m}, 3 \mathrm{H}, m, p-\mathrm{Ph}^{\mathrm{b}}\right), 6.38$ (br, BH), 1.49 (s, 6H, $\left.\mathrm{SCH}_{3}\right)$.

${ }^{13} \mathrm{C}\left\{{ }^{1} \mathrm{H}\right\}$ NMR (151 MHz, benzene- $\left.d_{6}, 299 \mathrm{~K}\right): \delta=152.4(\mathrm{br}, \mathrm{CH}=), 148.3(\mathrm{br}, \mathrm{BC}=), 146.3$ (br, $i$-Fmes), $142.9\left(i-\mathrm{Ph}^{\mathrm{a}}\right), 136.7\left(i-\mathrm{Ph}^{\mathrm{b}}\right), 133.5$ (q, $\left.{ }^{2} J_{\mathrm{FC}}=32.4 \mathrm{~Hz}, o-\mathrm{Fmes}\right), 131.3\left(\mathrm{~d},{ }^{2} \mathrm{~J}_{\mathrm{FC}}=34.3 \mathrm{~Hz}, p\right.$-Fmes), 131.0 $\left(o-\mathrm{Ph}^{b}\right), 129.3\left(p-\mathrm{Ph}^{b}\right), 129.0\left(m-\mathrm{Ph}^{\mathrm{a}}\right), 128.4\left(m-\mathrm{Ph}^{\mathrm{b}}\right), 128.1\left(o-\mathrm{Ph}^{\mathrm{a}}\right), 126.7\left(p-\mathrm{Ph}^{\mathrm{a}}\right), 126.0(\mathrm{br}, \mathrm{m}-$ Fmes), $124.5\left(q,{ }^{1} J_{\mathrm{FC}}=275.0 \mathrm{~Hz}, o-\mathrm{CF}_{3}\right), 123.2\left(\mathrm{q},{ }^{1} \mathrm{~J}_{\mathrm{FC}}=271.0 \mathrm{~Hz}, p-\mathrm{CF}_{3}\right), 19.4\left(\mathrm{SCH}_{3}\right)$.

${ }^{11} \mathrm{~B}\left\{{ }^{1} \mathrm{H}\right\}$ NMR $\left(192 \mathrm{MHz}\right.$, benzene- $\left.d_{6}, 299 \mathrm{~K}\right): \delta=53.3\left(\mathrm{v}_{1 / 2} \approx 1360 \mathrm{~Hz}\right)$.

${ }^{19} \mathrm{~F}$ NMR $\left(564 \mathrm{MHz}\right.$, benzene- $\left.d_{6}, 299 \mathrm{~K}\right): \delta=-57.8\left(\mathrm{~s}, 2 \mathrm{~F}, o-\mathrm{CF}_{3}\right),-63.0\left(\mathrm{~s}, 1 \mathrm{~F}, p-\mathrm{CF}_{3}\right)$. 


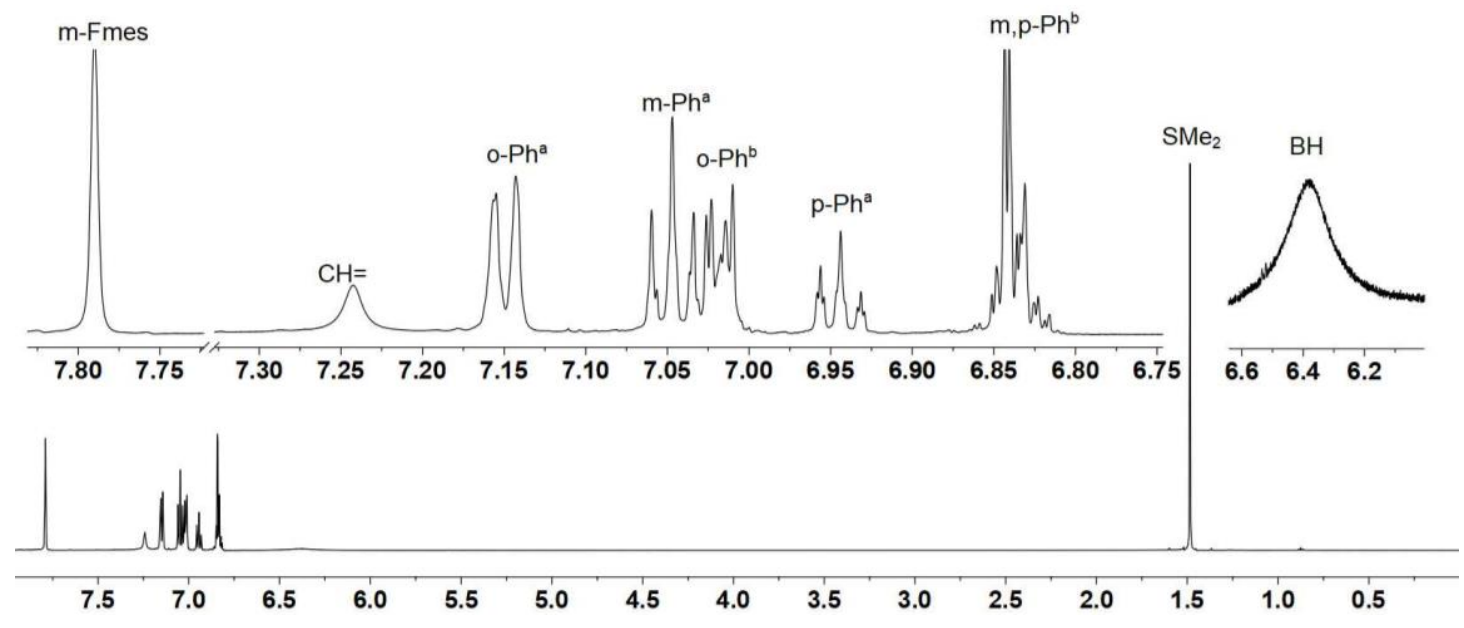

Figure S15. ${ }^{1} \mathrm{H}$ NMR (600 MHz, $\left.\mathrm{C}_{6} \mathrm{D}_{6}, 299 \mathrm{~K}\right)$ spectrum of compound $13 \mathrm{a}$.

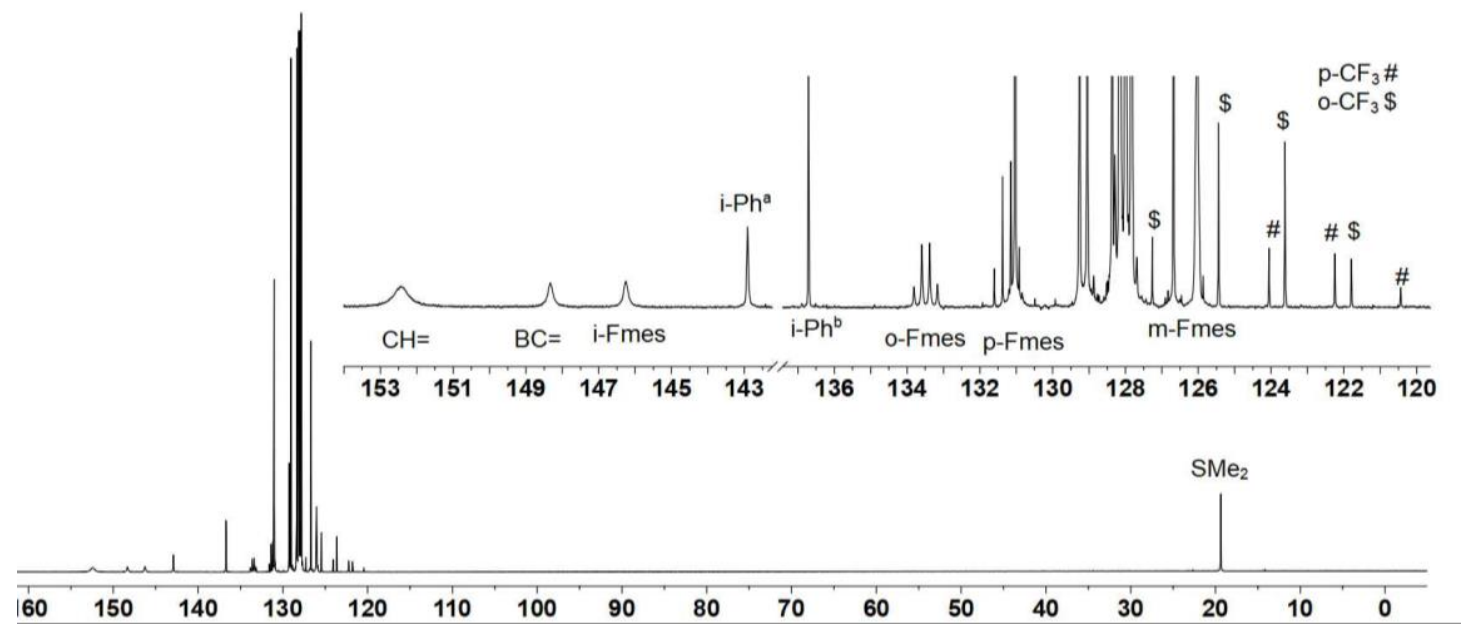

Figure S16. ${ }^{13} \mathrm{C}\left\{{ }^{1} \mathrm{H}\right\} \mathrm{NMR}\left(151 \mathrm{MHz}, \mathrm{C}_{6} \mathrm{D}_{6}, 299 \mathrm{~K}\right.$ ) spectrum of compound $13 \mathrm{a}$.

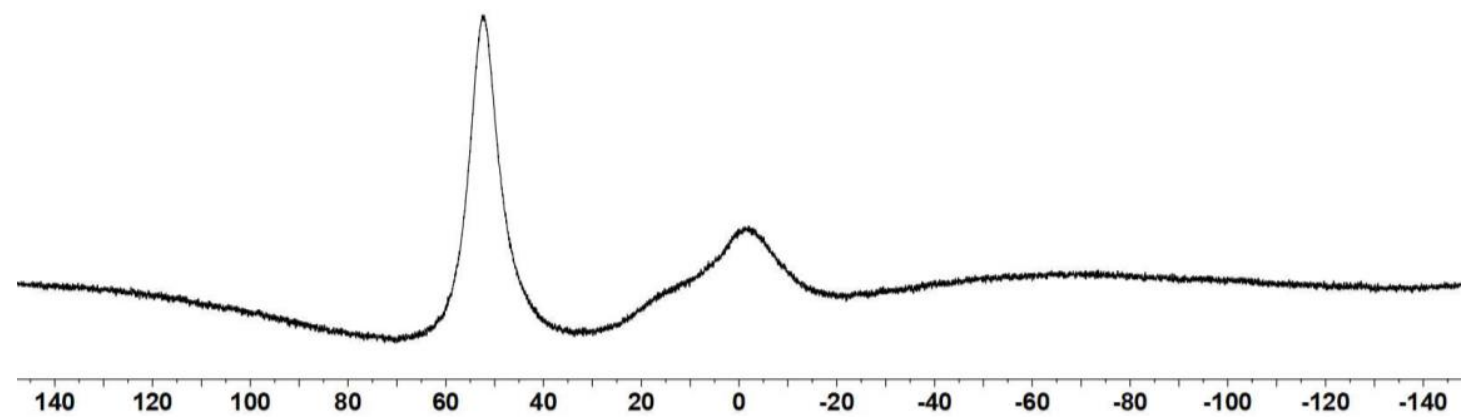

Figure S17. ${ }^{11} \mathrm{~B}\left\{{ }^{1} \mathrm{H}\right\} \mathrm{NMR}\left(192 \mathrm{MHz}, \mathrm{C}_{6} \mathrm{D}_{6}, 299 \mathrm{~K}\right)$ spectrum of compound $13 \mathrm{a}$. 


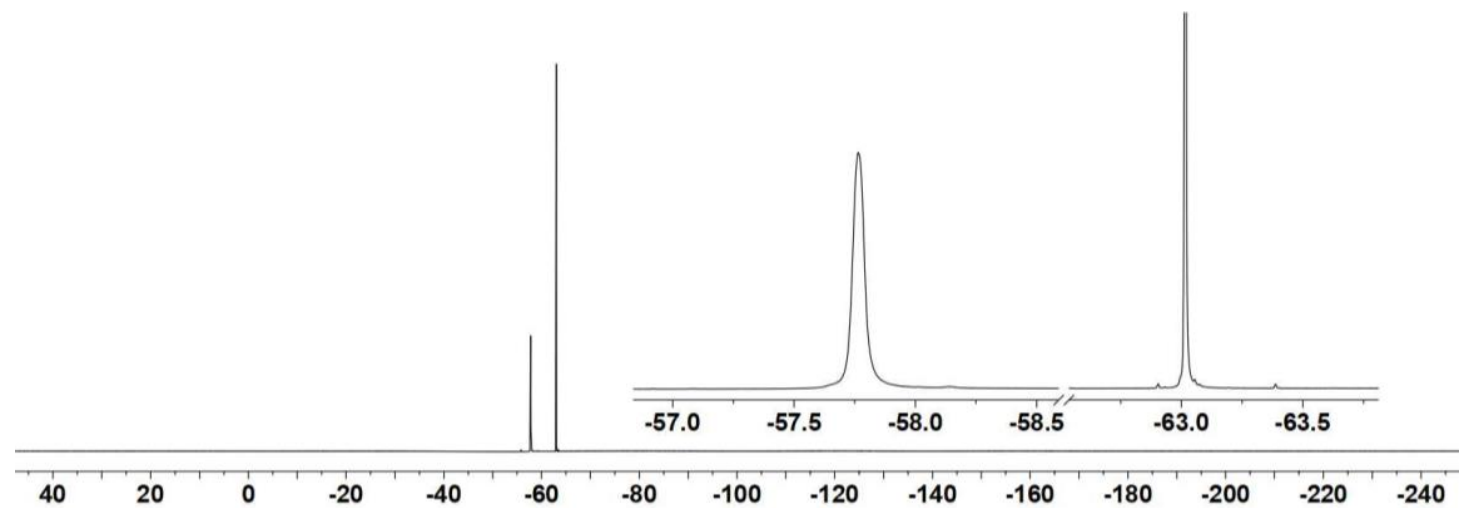

Figure S18. ${ }^{19} \mathrm{~F}$ NMR (564 MHz, $\mathrm{C}_{6} \mathrm{D}_{6}, 299 \mathrm{~K}$ ) spectrum of compound 13a.

Crystals suitable for the X-ray crystal structure analysis were obtained from a solution of compound 13a in cyclopentane at $-35^{\circ} \mathrm{C}$.

X-ray crystal structure analysis of compound 13a (erk9531): A colorless plate-like specimen of $\mathrm{C}_{25} \mathrm{H}_{20} \mathrm{BF} 9 \mathrm{~S}$, approximate dimensions $0.158 \mathrm{~mm} \times 0.189 \mathrm{~mm} \times 0.519 \mathrm{~mm}$, was used for the X-ray crystallographic analysis. The X-ray intensity data were measured. The hydrogen's at P1 and P2 atoms were refined freely. A total of 801 frames were collected. The total exposure time was 6.53 hours. The frames were integrated with the Bruker SAINT software package using a narrow-frame algorithm. The integration of the data using a monoclinic unit cell yielded a total of 157467 reflections to a maximum $\theta$ angle of $27.49^{\circ}(0.77 \AA$ resolution), of which 17139 were independent (average redundancy 9.188 , completeness $=99.8 \%, R_{\text {int }}=10.17 \%, R_{\text {sig }}=4.78 \%$ ) and $13066(76.24 \%)$ were greater than $2 \sigma\left(F^{2}\right)$. The final cell constants of $\underline{a}=28.1571(16) \AA, \underline{b}=9.6190(5) \AA, \underline{c}=$ $28.4643(16) \AA \AA \Omega=104.279(2)^{\circ}$, volume $=7471.2(7) \AA^{3}$, are based upon the refinement of the XYZcentroids of 9813 reflections above $20 \sigma(\mathrm{l})$ with $4.688^{\circ}<2 \theta<54.82^{\circ}$. Data were corrected for absorption effects using the multi-scan method (SADABS). The ratio of minimum to maximum apparent transmission was 0.861 . The calculated minimum and maximum transmission coefficients (based on crystal size) are 0.8990 and 0.9680 . The structure was solved and refined using the Bruker SHELXTL Software Package, using the space group $P 2_{1} / n$, with $Z=12$ for the formula unit, $\mathrm{C}_{25} \mathrm{H}_{20} \mathrm{BF}_{9} \mathrm{~S}$. The final anisotropic full-matrix least-squares refinement on $\mathrm{F}^{2}$ with 1112 variables converged at $R 1=6.98 \%$, for the observed data and $\mathrm{WR} 2=14.42 \%$ for all data. The goodness-of-fit was 1.131. The largest peak in the final difference electron density synthesis was $0.440 \mathrm{e}^{-} / \AA^{3}$ and the largest hole was $-0.390 \mathrm{e}^{-} / \AA^{3}$ with an RMS deviation of $0.059 \mathrm{e}^{-} / \AA^{3}$. On the basis of the final model, the calculated density was $1.425 \mathrm{~g} / \mathrm{cm}^{3}$ and $F(000), 3264 \mathrm{e}$. The hydrogen's at B1A, B1B and B1C atoms were refined freely. CCDC number: 2007633. 


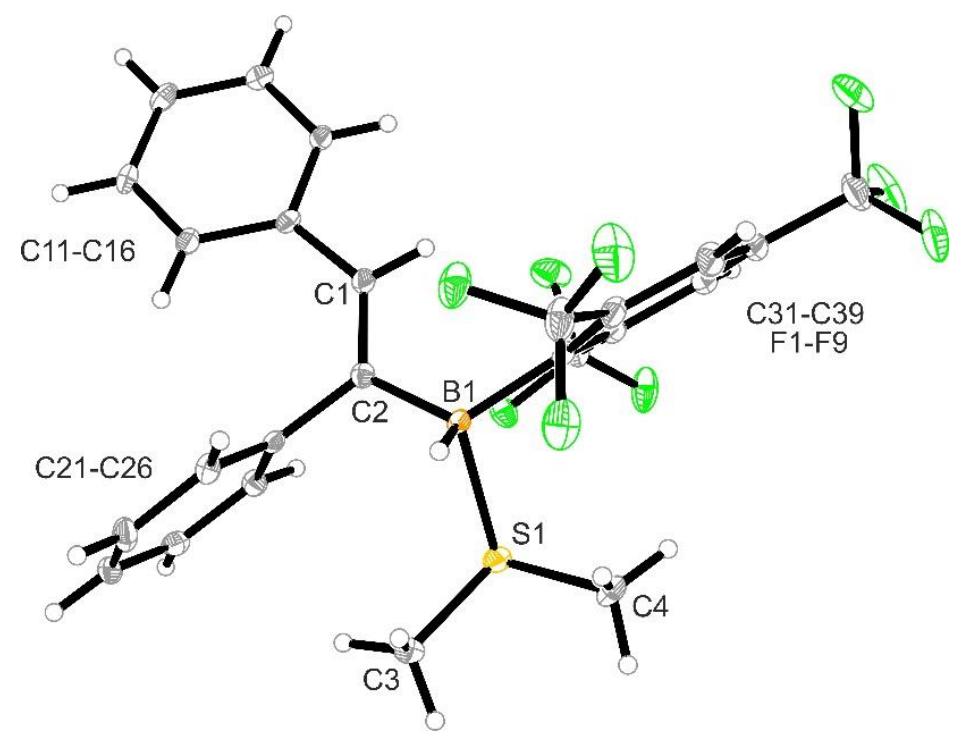

Figure S19. Crystal structure of compound 13a (thermal ellipsoids at 30\% probability).

\section{Preparation of compound 16b}<smiles>CSc1c(C(F)(F)F)cc(C(F)(F)F)cc1C(F)(F)F</smiles>

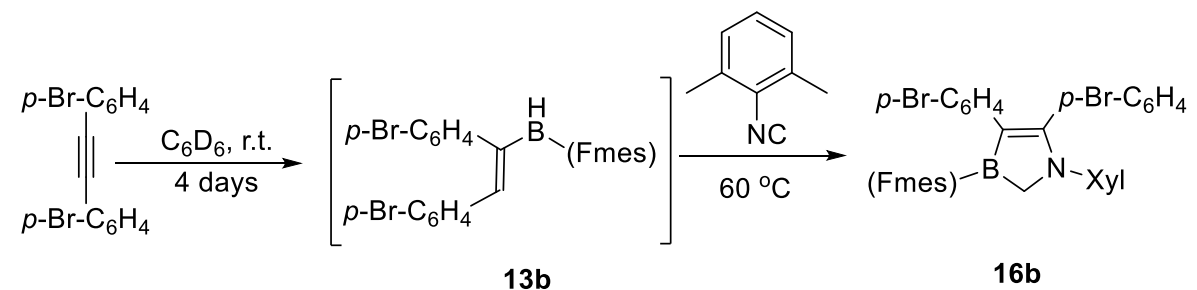

Scheme S6.

At room temperature, borane $7 \cdot \mathrm{SMe}_{2}(106.8 \mathrm{mg}, 0.3 \mathrm{mmol}, 1 \mathrm{eq}$.) was added to a suspension of 1,2-bis(4-bromophenyl)ethyne $16 \mathrm{~b}$ (100.8 mg, $0.3 \mathrm{mmol}, 1$ eq.) in $\mathrm{C}_{6} \mathrm{D}_{6}(2 \mathrm{~mL})$ under argon atmosphere in a J. Young tube. The mixture was shaken for 4 days at room temperature to give a light red solution. The formation of the hydroboration product was monitored by an in situ NMR experiment. Then 2,6-dimethylphenylisocyanide $(39.3 \mathrm{mg}, 0.3 \mathrm{mmol}, 1 \mathrm{eq}$.) was added to the mixture in one portion to give a brown solution. The resulting solution was stored at $60^{\circ} \mathrm{C}$ for $5 \mathrm{~h}$. All volatiles were removed in vacuo. Subsequently, the residue was dissolved in pentane $(2 \mathrm{~mL})$ and stored at $-35{ }^{\circ} \mathrm{C}$ to finally give the compound $16 \mathrm{~b}$ as an olive solid (163 mg, $71 \%$ yield).

Elemental Analysis for $\mathrm{C}_{32} \mathrm{H}_{21} \mathrm{BNF}_{9} \mathrm{Br}_{2}$ : calc. C (50.50\%), $\mathrm{H}(2.78 \%), \mathrm{N}(1.84 \%)$; found: $\mathrm{C}(50.42 \%)$, $\mathrm{H}(2.80 \%), \mathrm{N}(1.83 \%)$;

${ }^{1} \mathrm{H}$ NMR (600 MHz, methylene chloride- $\left.d_{2}, 299 \mathrm{~K}\right): \delta=8.11(\mathrm{~s}, 2 \mathrm{H}, m-\mathrm{Fmes}), 7.28\left(\mathrm{~m}, 2 \mathrm{H}, m-\mathrm{C}_{6} \mathrm{H}_{4} \mathrm{Br}^{\mathrm{N}}\right)$, $7.09(\mathrm{~m}, 1 \mathrm{H}, p-\mathrm{Xyl}), 7.07\left(\mathrm{~m}, 2 \mathrm{H}, m-\mathrm{C}_{6} \mathrm{H}_{4} \mathrm{Br}^{\mathrm{B}}\right), 7.01\left(\mathrm{~d},{ }^{3} \mathrm{HHH}_{\mathrm{HH}}=7.6 \mathrm{~Hz}, 2 \mathrm{H}, m-X y l\right), 6.98(\mathrm{~m}, 2 \mathrm{H}, o-$ $\left.\mathrm{C}_{6} \mathrm{H}_{4} \mathrm{Br}^{\mathrm{N}}\right), 6.58\left(\mathrm{~m}, 2 \mathrm{H}, \mathrm{o}-\mathrm{C}_{6} \mathrm{H}_{4} \mathrm{Br}^{\mathrm{B}}\right), 3.82\left(\mathrm{~s}, 2 \mathrm{H}, \mathrm{CH}_{2}\right), 2.19\left(\mathrm{~s}, 6 \mathrm{H}, \mathrm{o}-\mathrm{CH}_{3}{ }^{\mathrm{Xy}}\right)$.

${ }^{13} \mathrm{C}\left\{{ }^{1} \mathrm{H}\right\}$ NMR (151 MHz, methylene chloride- $\left.d_{2}, 299 \mathrm{~K}\right): \delta=177.8(\mathrm{CN}=), 144.8(\mathrm{br}, i-\mathrm{Fmes}), 140.6(i-$ $\mathrm{Xyl}), 139.0\left(i-\mathrm{C}_{6} \mathrm{H}_{4} \mathrm{Br}{ }^{\mathrm{B}}\right), 136.8(o-\mathrm{Xyl}), 134.0\left(\mathrm{q},{ }^{2} \mathrm{~J}_{\mathrm{FC}}=31.1 \mathrm{~Hz}, o-\mathrm{Fmes}\right), 132.0\left(i-\mathrm{C}_{6} \mathrm{H}_{4} \mathrm{Br}^{\mathrm{N}}\right), 131.5(\mathrm{~m}-$ $\left.\mathrm{C}_{6} \mathrm{H}_{4} \mathrm{Br}^{\mathrm{N}}\right), 131.25\left(o-\mathrm{C}_{6} \mathrm{H}_{4} \mathrm{Br}^{\mathrm{N}}\right), 131.18\left(o-\mathrm{C}_{6} \mathrm{H}_{4} \mathrm{Br}^{\mathrm{B}}\right), 131.0\left(m-\mathrm{C}_{6} \mathrm{H}_{4} \mathrm{Br}^{\mathrm{B}}\right), 130.8$ (q, ${ }^{2} J_{\mathrm{FC}}=34.3 \mathrm{~Hz}, p-$ Fmes), 128.8 ( $m$-Xyl), 128.3 ( $p$-Xyl), 126.0 (br, $m$-Fmes), 124.2 (q, $\left.{ }^{1} \mathrm{JFC}_{\mathrm{FC}}=275.4 \mathrm{~Hz}, o-\mathrm{CF}_{3}{ }^{\mathrm{Fmes}}\right), 123.4$ $\left(q,{ }^{1} \mathrm{JFC}_{\mathrm{FC}}=269.7 \mathrm{~Hz}, p-\mathrm{CF}_{3}{ }^{\mathrm{Fmes}}\right), 124.1\left(p-\mathrm{C}_{6} \mathrm{H}_{4} \mathrm{Br}^{\mathrm{N}}\right), 122.3(\mathrm{br}, \mathrm{BC}=), 117.9\left(p-\mathrm{C}_{6} \mathrm{H}_{4} \mathrm{Br}^{\mathrm{B}}\right), 56.9\left(\mathrm{br}, \mathrm{CH}_{2}\right)$, 
$17.9\left(0-\mathrm{CH}_{3}{ }^{\mathrm{Xy}}\right)$.

${ }^{11} \mathbf{B}\left\{{ }^{1} \mathrm{H}\right\}$ NMR $\left(192 \mathrm{MHz}\right.$, methylene chloride- $\left.d_{2}, 299 \mathrm{~K}\right): \delta=59.4\left(\mathrm{v}_{1 / 2} \approx 1080 \mathrm{~Hz}\right)$.

${ }^{19} \mathrm{~F}$ NMR (564 MHz, methylene chloride- $\left.d_{2}, 299 \mathrm{~K}\right): \delta=-58.3\left(\mathrm{~s}, 2 \mathrm{~F}, o-\mathrm{CF}_{3}{ }^{\mathrm{Fmes}}\right),-63.5\left(\mathrm{~s}, 1 \mathrm{~F}, p-\mathrm{CF}_{3}{ }^{\mathrm{Fmes}}\right)$.
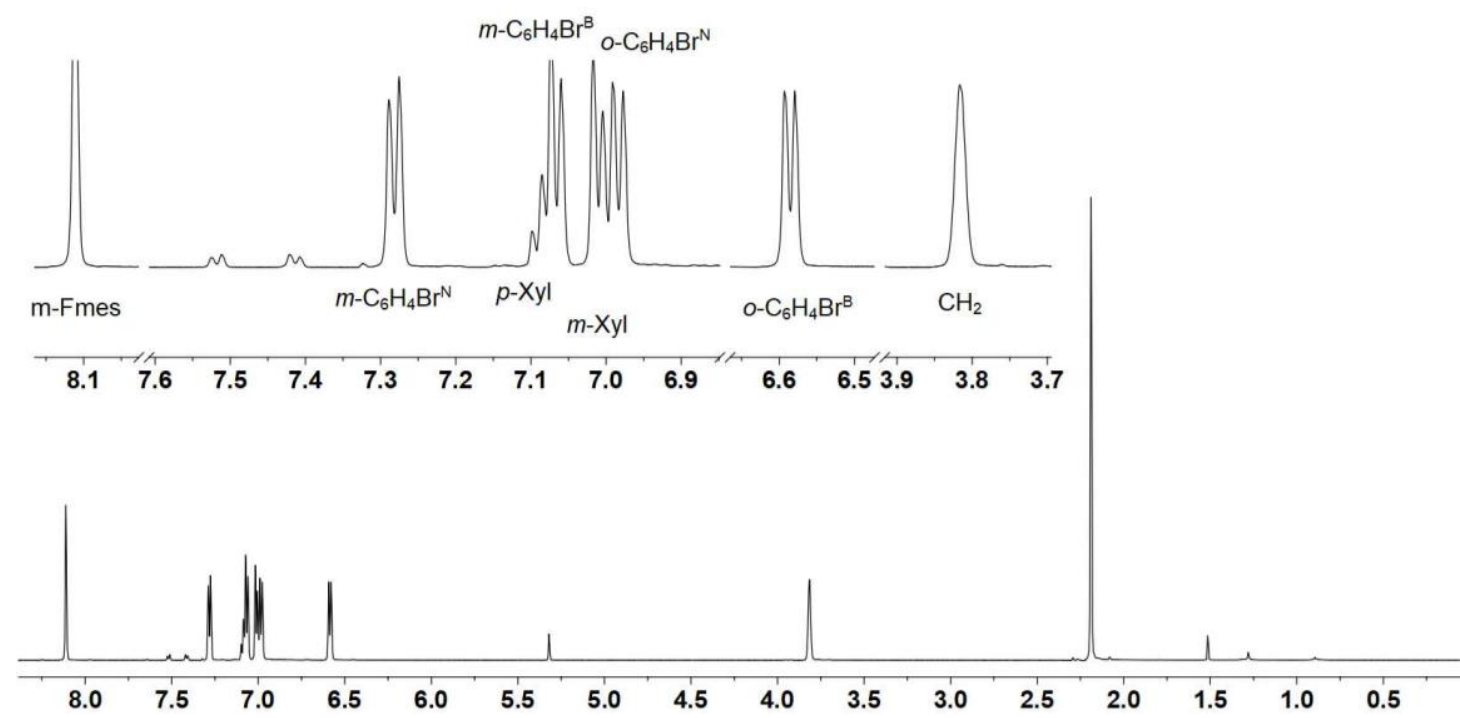

Figure S20. ${ }^{1} \mathrm{H}$ NMR (600 MHz, methylene chloride- $d_{2}, 299 \mathrm{~K}$ ) spectrum of compound 16b.

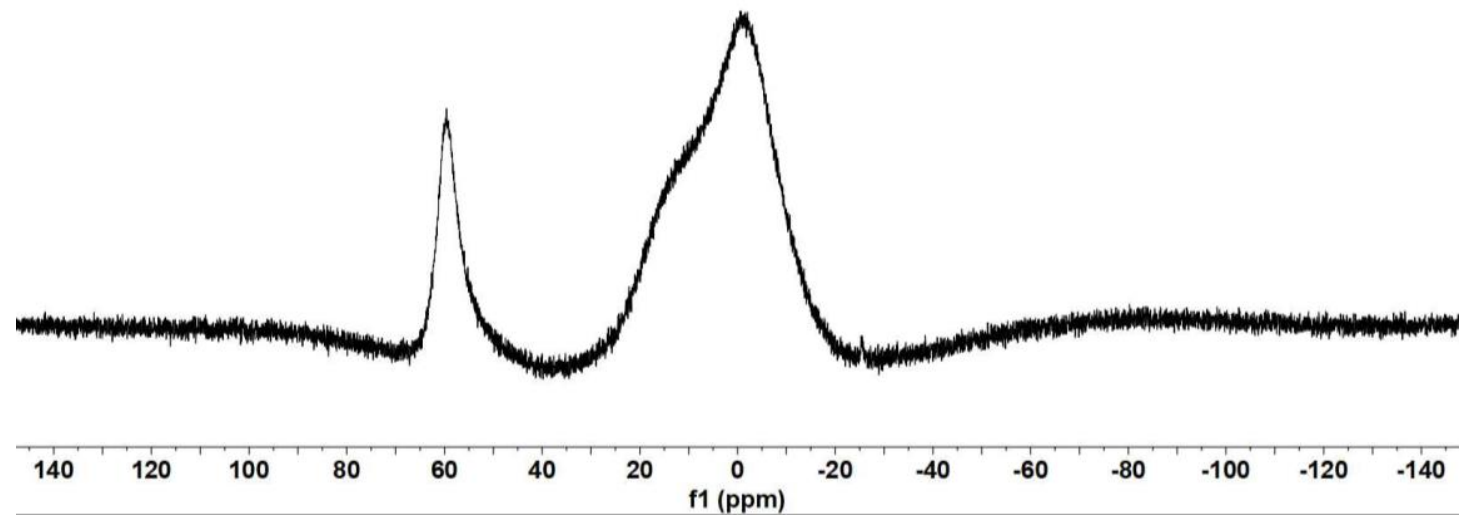

Figure S21. ${ }^{11} \mathrm{~B}\left\{{ }^{1} \mathrm{H}\right\}$ NMR (192 MHz, methylene chloride- $\left.d_{2}, 299 \mathrm{~K}\right)$ spectrum of compound 16b.

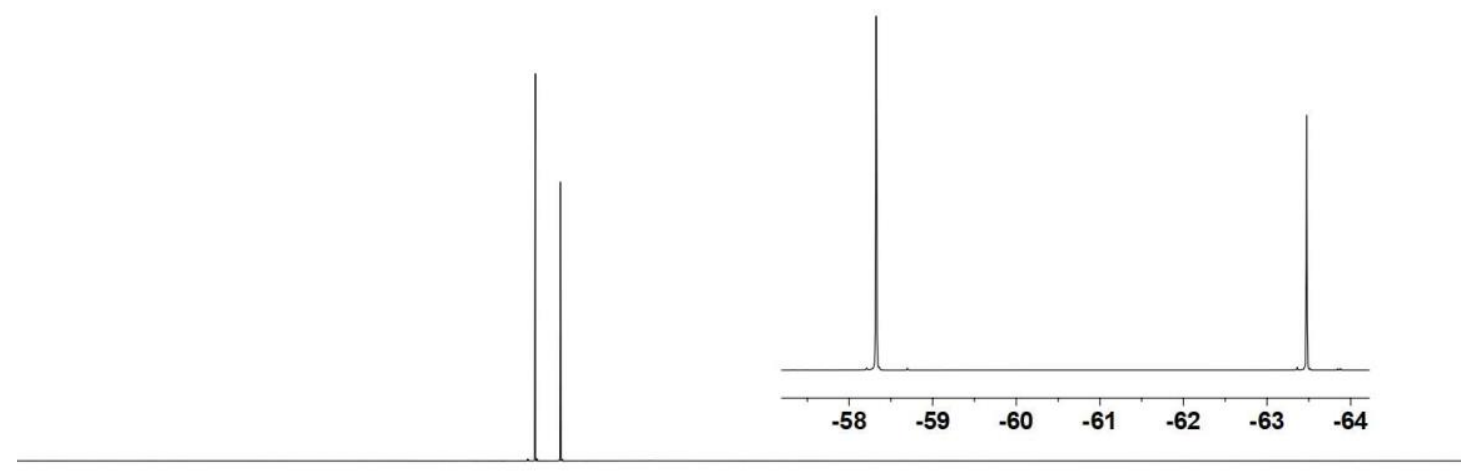

$\begin{array}{llllllllllllllll}40 & 20 & 0 & -20 & -40 & -60 & -80 & -100 & -120 & -140 & -160 & -180 & -200 & -220 & -240\end{array}$

Figure S22. ${ }^{19} \mathrm{~F}$ NMR (564 MHz, methylene chloride, $299 \mathrm{~K}$ ) spectrum of compound 16b. 

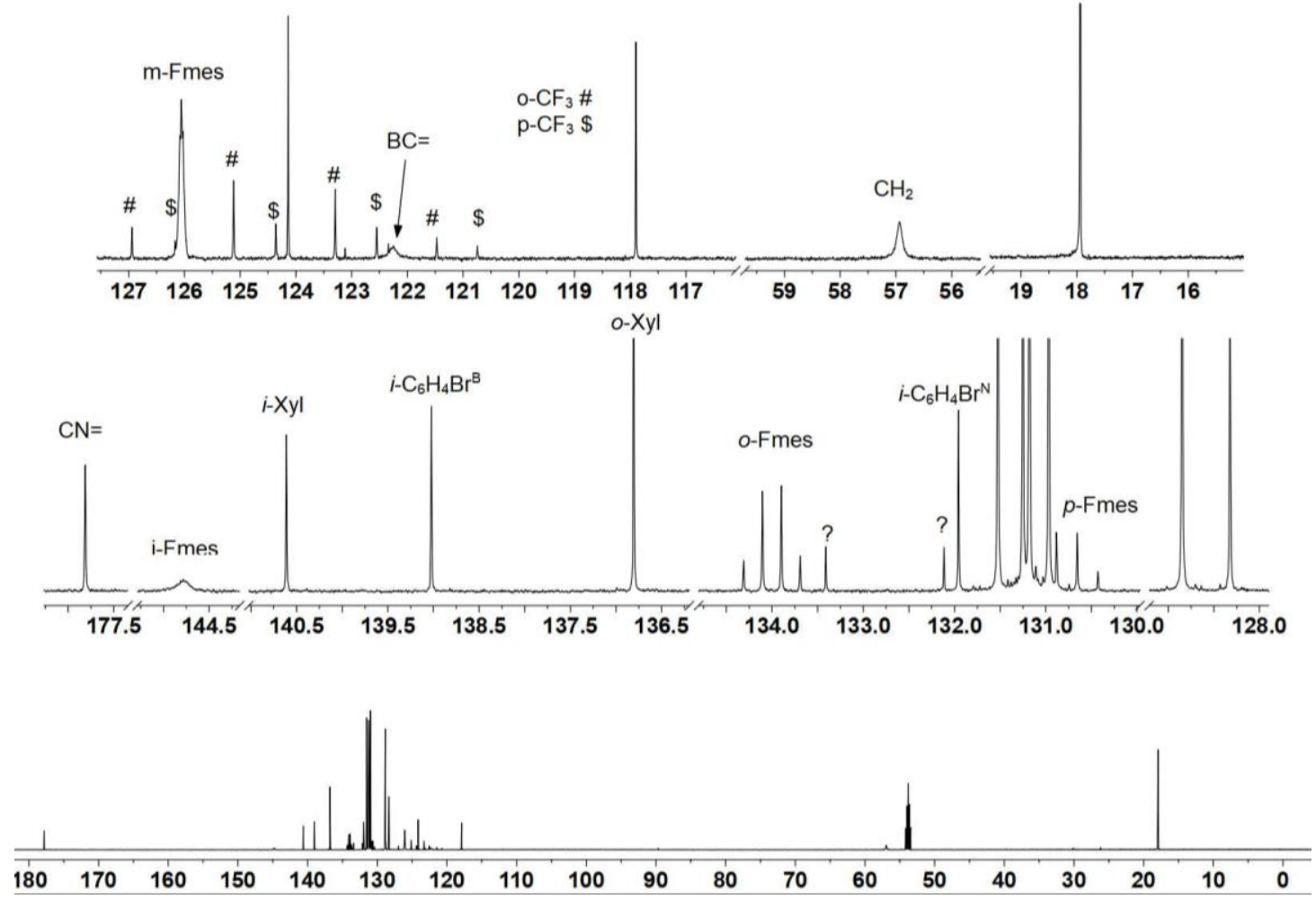

Figure S23. ${ }^{13} \mathrm{C}\left\{{ }^{1} \mathrm{H}\right\}$ NMR (151 MHz, methylene chloride- $d_{2}, 299 \mathrm{~K}$ ) spectrum of compound $\mathbf{1 6 b}$.

The in situ NMR spectra of the hydroboration product 13b (with a small amount of starting material):

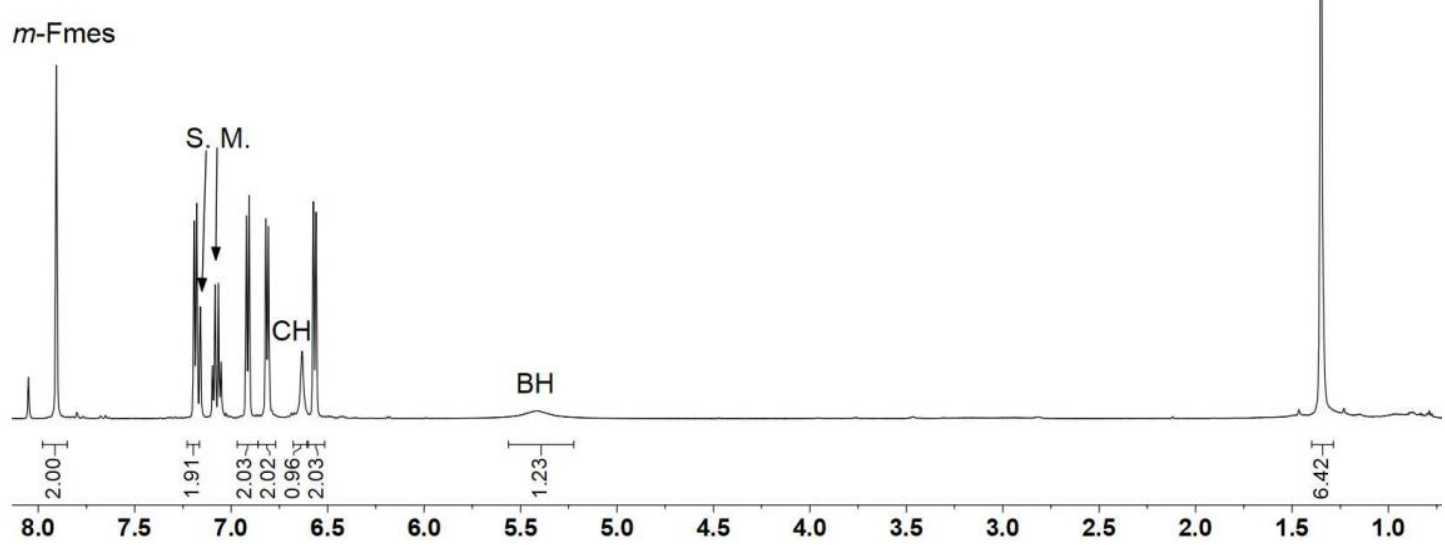

Figure S24. ${ }^{1} \mathrm{H}$ NMR $\left(600 \mathrm{MHz}, \mathrm{C}_{6} \mathrm{D}_{6}, 299 \mathrm{~K}\right)$ spectrum of compound 13b (S.M. = 1,2-bis(4bromophenyl)ethyne). 


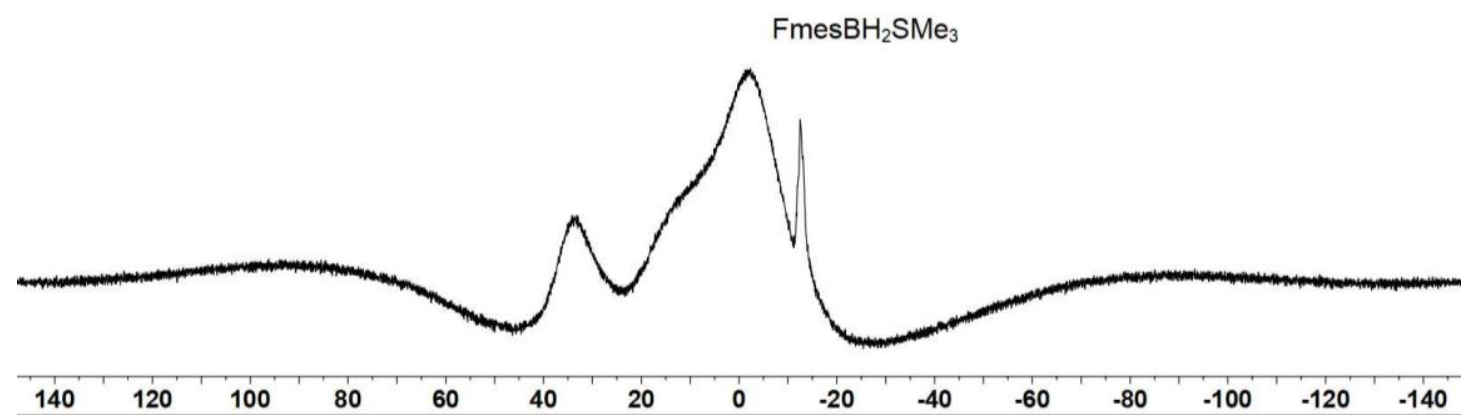

Figure S25. ${ }^{11} B$ NMR (192 MHz, $C_{6} D_{6}, 299 \mathrm{~K}$ ) spectrum of compound 13b.

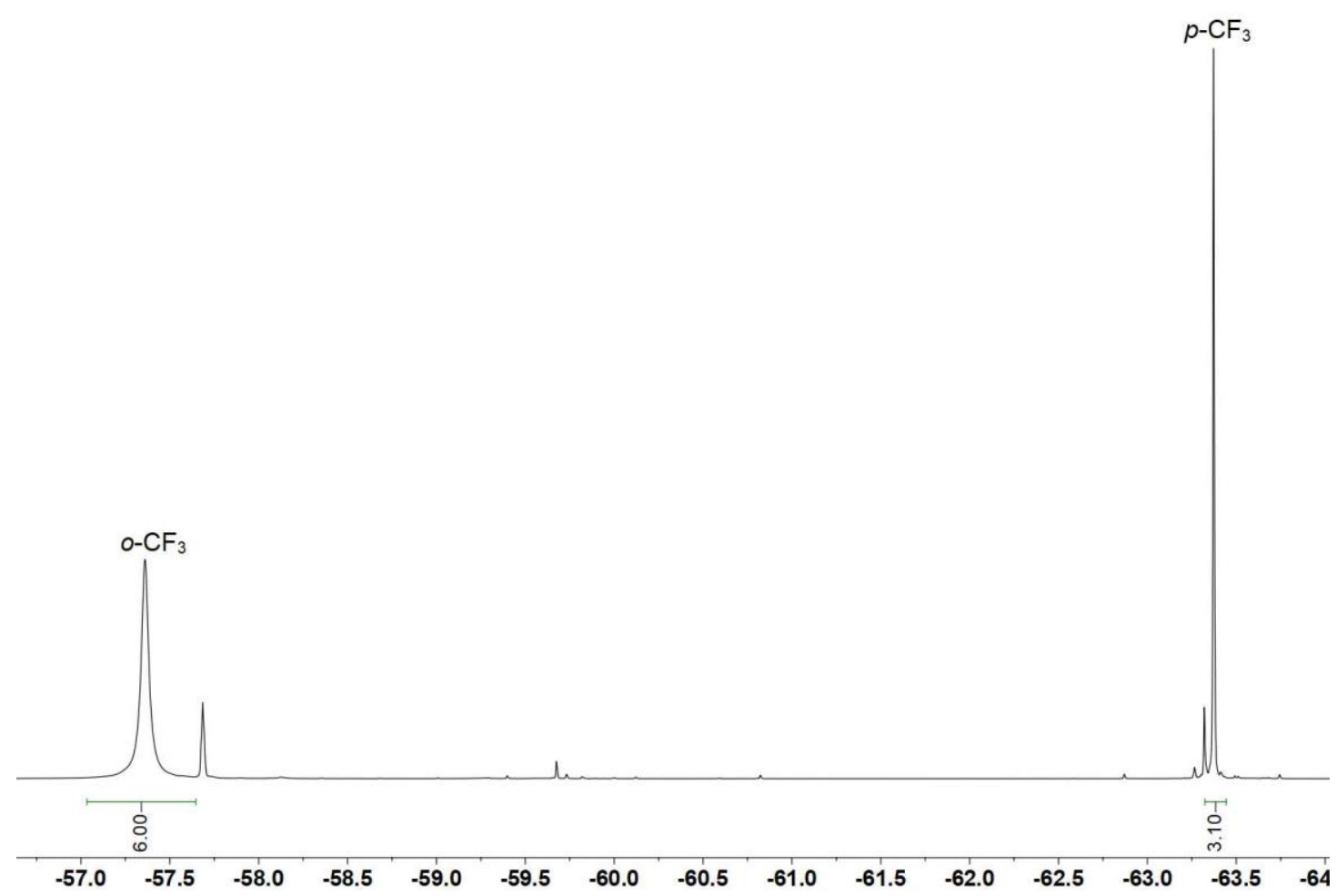

Figure S26. ${ }^{19} \mathrm{~F} N M R\left(564 \mathrm{MHz}, \mathrm{C}_{6} \mathrm{D}_{6}, 299 \mathrm{~K}\right.$ ) spectrum of compound $\mathbf{1 3 b}$.

Crystals suitable for X-ray crystal structure analysis were obtained from a solution of compound $16 \mathrm{~b}$ in cyclopentane at $-35^{\circ} \mathrm{C}$.

X-ray crystal structure analysis of compound 16b (erk9454): A colorless plate-like specimen of $\mathrm{C}_{32} \mathrm{H}_{21} \mathrm{BBr}_{2} \mathrm{~F}_{9} \mathrm{~N}$, approximate dimensions $0.020 \mathrm{~mm} \times 0.050 \mathrm{~mm} \times 0.060 \mathrm{~mm}$, was used for the $\mathrm{X}$-ray crystallographic analysis. The X-ray intensity data were measured. A total of 1456 frames were collected. The total exposure time was 23.86 hours. The frames were integrated with the Bruker SAINT software package using a wide-frame algorithm. The integration of the data using a triclinic unit cell yielded a total of 18923 reflections to a maximum $\theta$ angle of $66.70^{\circ}$ ( $0.84 \AA$ resolution), of which 5217 were independent (average redundancy 3.627 , completeness $=98.8 \%, R_{\text {int }}=8.71 \%, R_{\text {sig }}$ $=8.18 \%)$ and $3539(67.84 \%)$ were greater than $2 \sigma\left(\mathrm{F}^{2}\right)$. The final cell constants of $\underline{a}=10.0146(6) \AA$, $\underline{b}=11.7824(7) \AA, \underline{c}=14.7823(9) \AA, \alpha=66.606(4)^{\circ}, \beta=81.108(4)^{\circ}, \gamma=68.680(4)^{\circ}$, volume = 1491.21(17) $\AA^{3}$, are based upon the refinement of the XYZ-centroids of 2399 reflections above 20 $\sigma(\mathrm{l})$ with $6.515^{\circ}<2 \theta<133.1^{\circ}$. Data were corrected for absorption effects using the multi-scan 
method (SADABS). The ratio of minimum to maximum apparent transmission was 0.804 . The calculated minimum and maximum transmission coefficients (based on crystal size) are 0.7870 and 0.9210. The structure was solved and refined using the Bruker SHELXTL Software Package, using the space group $P-1$, with $Z=2$ for the formula unit, $\mathrm{C}_{32} \mathrm{H}_{21} \mathrm{BBr}_{2} \mathrm{~F}_{9} \mathrm{~N}$. The final anisotropic full-matrix least-squares refinement on $\mathrm{F}^{2}$ with 465 variables converged at $\mathrm{R} 1=6.04 \%$, for the observed data and $\mathrm{WR2}=16.23 \%$ for all data. The goodness-of-fit was 1.090 . The largest peak in the final difference electron density synthesis was $0.623 \mathrm{e}^{-} / \AA^{3}$ and the largest hole was $-0.625 \mathrm{e}^{-} / \AA^{3}$ with an RMS deviation of $0.115 \mathrm{e}^{-} / \AA^{3}$. On the basis of the final model, the calculated density was 1.695 $\mathrm{g} / \mathrm{cm}^{3}$ and $\mathrm{F}(000), 752 \mathrm{e} \cdot \mathrm{CCDC}$ number: 2007635.

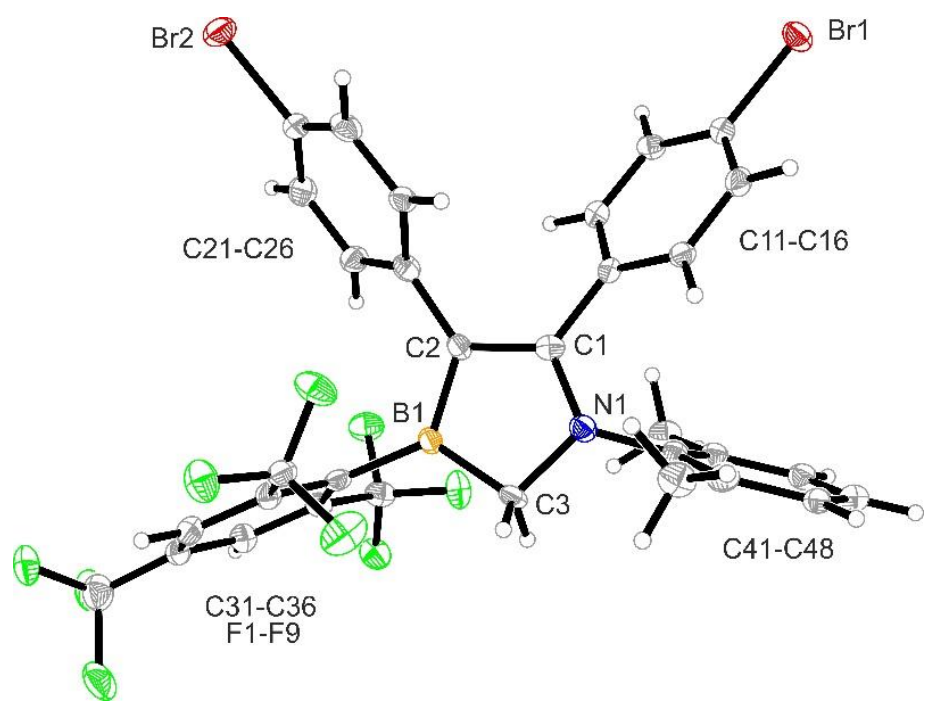

Figure S27. Crystal structure of compound $\mathbf{1 6 b}$ (thermal ellipsoids at 30\% probability).

\section{Preparation of compound 16c}

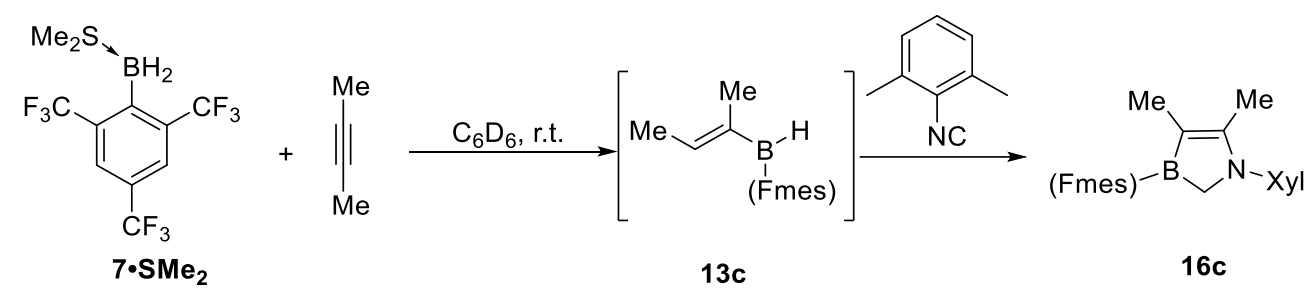

Scheme S7.

At room temperature, borane $7 \mathrm{a} \cdot \mathrm{SMe}_{2}(142.4 \mathrm{mg}, 0.4 \mathrm{mmol}, 1 \mathrm{eq}$.) was added to the solution of 2-butyne (21.6mg, $0.4 \mathrm{mmol}, 1$ eq.) in $\mathrm{C}_{6} \mathrm{D}_{6}(2 \mathrm{~mL})$ under argon atmosphere in a J. Young tube. Then the mixture was stored for $30 \mathrm{~min}$ to give a colorless solution. The formation of the hydroboration product was monitored by in situ NMR experiment. Then 2,6-dimethylphenylisocyanide (52.4 mg, $0.4 \mathrm{mmol}, 1 \mathrm{eq}$.) was added to the mixture in one portion to give a brown solution. The resulting solution was stored at room temperature for 2 days. Then all volatiles were removed in vacuo. Subsequently, the residue was dissolved in pentane $(1 \mathrm{~mL})$ and stored at $-35^{\circ} \mathrm{C}$ to finally give the compound $16 \mathrm{c}$ as a light yellow solid (106 $\mathrm{mg}, 56 \%$ yield).

Element Analysis for $\mathrm{C}_{22} \mathrm{H}_{19} \mathrm{BNF}_{9}$ : calc. C (55.14\%), H (4.00\%), N (2.92 \%); found: C (54.73\%), H 
(4.10\%), N (2.73\%);

HRMS for $\mathrm{C}_{22} \mathrm{H}_{22} \mathrm{BNF}_{9} \mathrm{O}^{+}\left[\mathrm{M}+\mathrm{H}_{3} \mathrm{O}\right]^{+}$: calc. 498.1649; found: 498.1669 .

${ }^{1} \mathrm{H}$ NMR $\left(600 \mathrm{MHz}\right.$, methylene chloride- $\left.d_{2}, 299 \mathrm{~K}\right): \delta=8.12(\mathrm{~s}, 2 \mathrm{H}, m$-Fmes), $7.17(\mathrm{~m}, 1 \mathrm{H}, p$-Xyl), $7.13(\mathrm{~m}, 2 \mathrm{H}, m-\mathrm{Xyl}), 3.43\left(\mathrm{~m}, 2 \mathrm{H}, \mathrm{CH}_{2}\right), 2.10\left(\mathrm{~s}, 6 \mathrm{H}, \mathrm{o}-\mathrm{CH}_{3}{ }^{\mathrm{Xyl}}\right), 1.86\left(\mathrm{t}, J=1.9 \mathrm{~Hz}, 3 \mathrm{H}, \mathrm{CH}_{3}{ }^{\mathrm{N}}\right), 1.67(\mathrm{~s}$, $\left.3 \mathrm{H}, \mathrm{CH}_{3}{ }^{\mathrm{B}}\right)$.

${ }^{13} \mathrm{C}\left\{{ }^{1} \mathrm{H}\right\}$ NMR (151 MHz, methylene chloride- $d_{2}, 299 \mathrm{~K}$ ): $\delta=179.4$ (NC=), 147.5 (br, i-Fmes), 141.1 $(i-\mathrm{Xyl}), 137.8(o-\mathrm{Xyl}), 134.1$ (q, ${ }^{2} \mathrm{~J}_{\mathrm{FC}}=30.8 \mathrm{~Hz}, o$-Fmes), 130 (q, ${ }^{2} \mathrm{~J}_{\mathrm{FC}}=34.0 \mathrm{~Hz}, p$-Fmes), $128.7(m-\mathrm{Xyl})$, 128.1 ( $p$-Xyl), 125.5 (br, $m$-Fmes), 124.3 (q, $\left.{ }^{1} J_{\mathrm{FC}}=274.4 \mathrm{~Hz}, o-\mathrm{CF}_{3}\right), 123.7\left(\mathrm{q},{ }^{1} \mathrm{JFC}_{\mathrm{FC}}=271.7 \mathrm{~Hz}, p-\mathrm{CF}_{3}\right.$ ), $114.8(\mathrm{br}, \mathrm{BC}=), 55.0\left(\mathrm{br}, \mathrm{CH}_{2}\right), 17.3\left(0-\mathrm{CH}_{3}{ }^{\mathrm{Xyl}}\right), 13.7\left(\mathrm{CH}_{3}{ }^{\mathrm{N}}\right), 11.4\left(\mathrm{CH}_{3}^{\mathrm{B}}\right)$.

${ }^{11} \mathrm{~B}\left\{{ }^{1} \mathrm{H}\right\}$ NMR $\left(192 \mathrm{MHz}\right.$, methylene chloride- $\left.d_{2}, 299 \mathrm{~K}\right): \delta=57.5\left(\mathrm{v}_{1 / 2} \approx 400 \mathrm{~Hz}\right)$.

${ }^{19} \mathrm{~F}$ NMR (564 MHz, methylene chloride- $\left.d_{2}, 299 \mathrm{~K}\right): \delta=-59.4\left(\mathrm{~m}, 2 \mathrm{~F}, o-\mathrm{CF}_{3}\right),-63.4\left(\mathrm{~s}, 1 \mathrm{~F}, p-\mathrm{CF}_{3}\right)$.

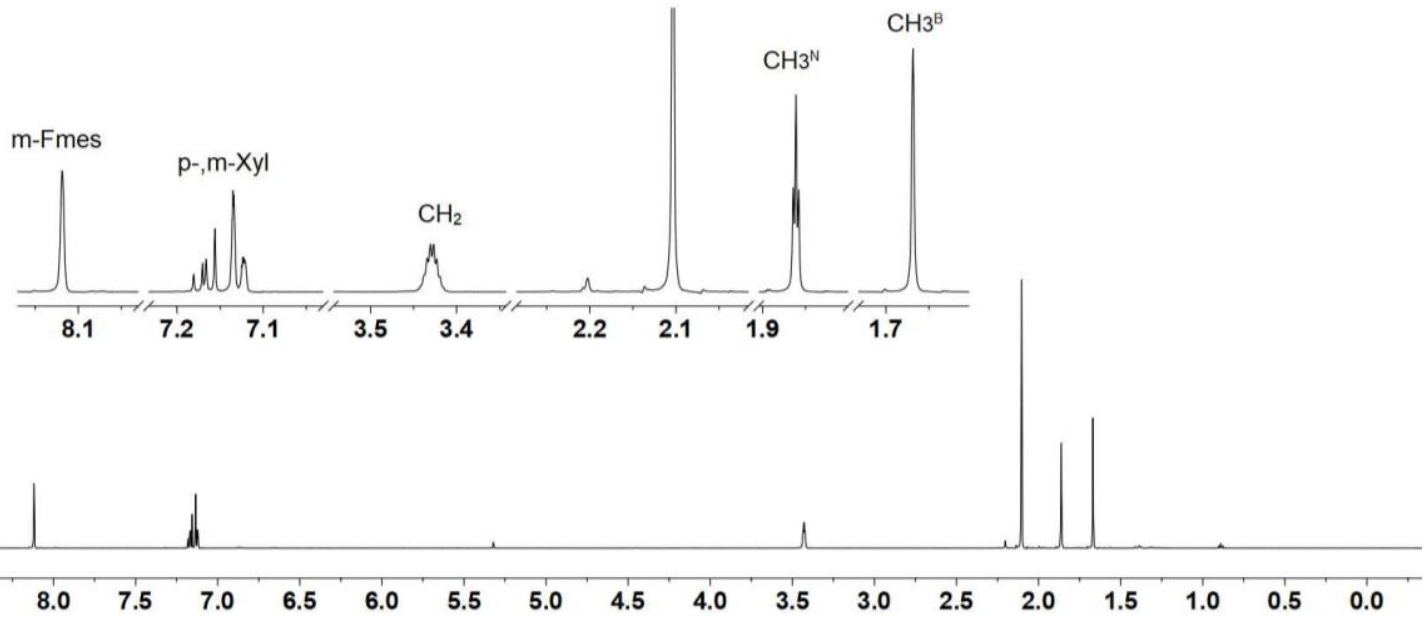

Figure S28. ${ }^{1} \mathrm{H}$ NMR (600 MHz, methylene chloride- $d_{2}, 299 \mathrm{~K}$ ) spectrum of compound $16 \mathrm{c}$.
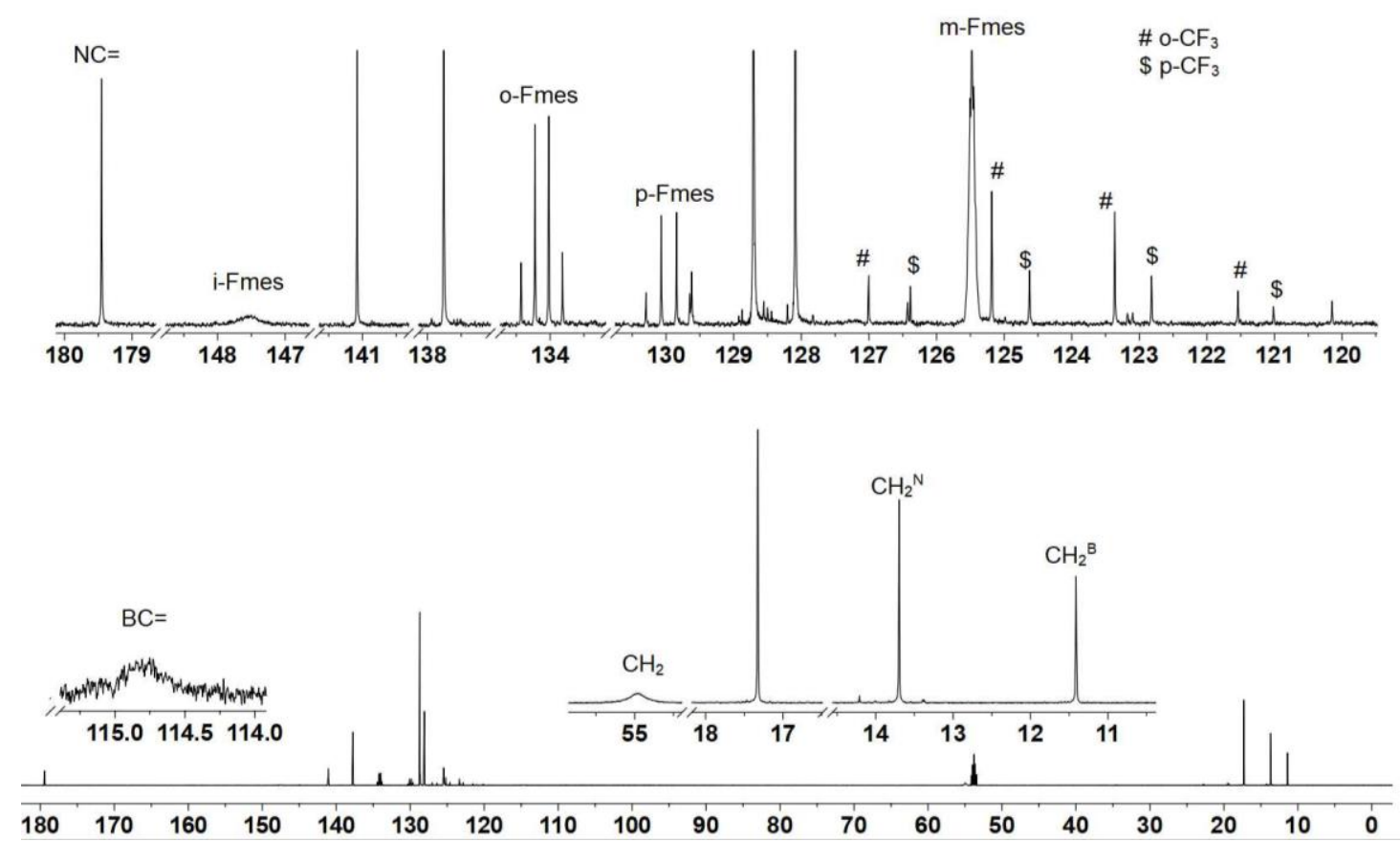

Figure S29. ${ }^{13} \mathrm{C}\left\{{ }^{1} \mathrm{H}\right\}$ NMR (151 MHz, methylene chloride- $d_{2}, 299 \mathrm{~K}$ ) spectrum of compound $\mathbf{1 6 c}$. 


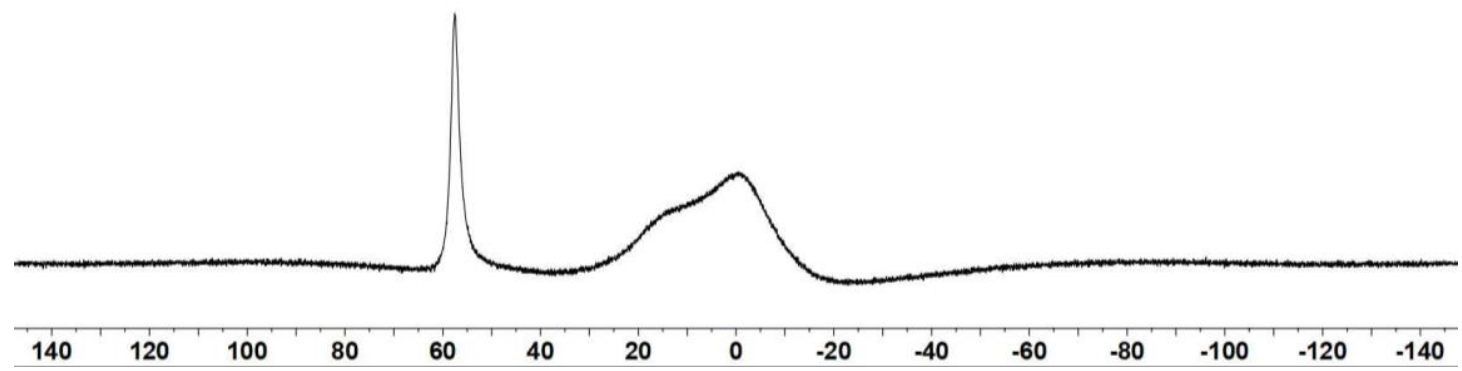

Figure S30. ${ }^{11} \mathrm{~B}\left\{{ }^{1} \mathrm{H}\right\} \mathrm{NMR}\left(192 \mathrm{MHz}\right.$, methylene chloride- $\left.d_{2}, 299 \mathrm{~K}\right)$ spectrum of compound $\mathbf{1 6 c}$.

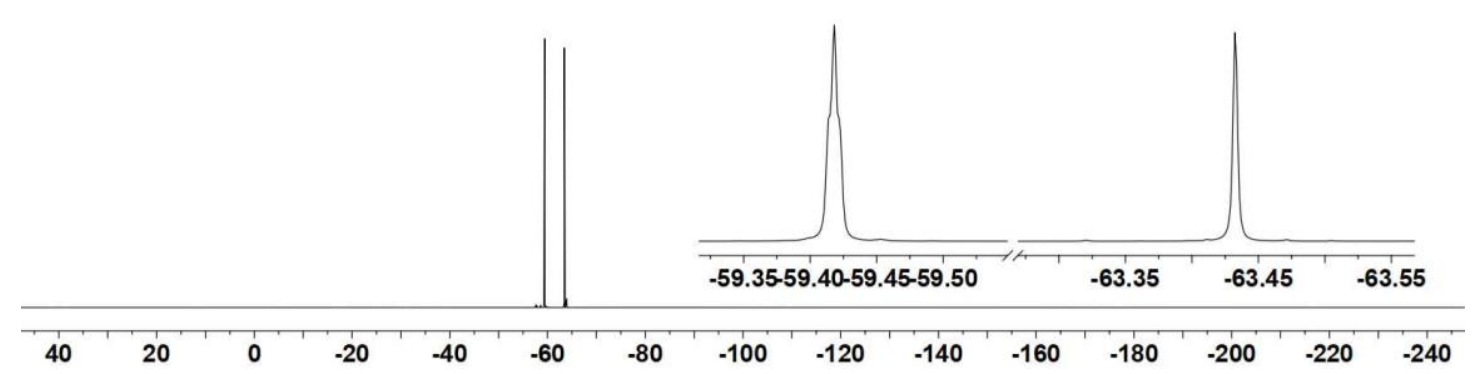

Figure S31. ${ }^{19} \mathrm{~F}$ NMR $\left(564 \mathrm{MHz}\right.$, methylene chloride- $\left.d_{2}, 299 \mathrm{~K}\right)$ spectrum of compound $\mathbf{1 6 c}$.

The in situ NMR spectra of the hydroboration product $13 \mathrm{c}$ (with small amount di-hydroboration products):

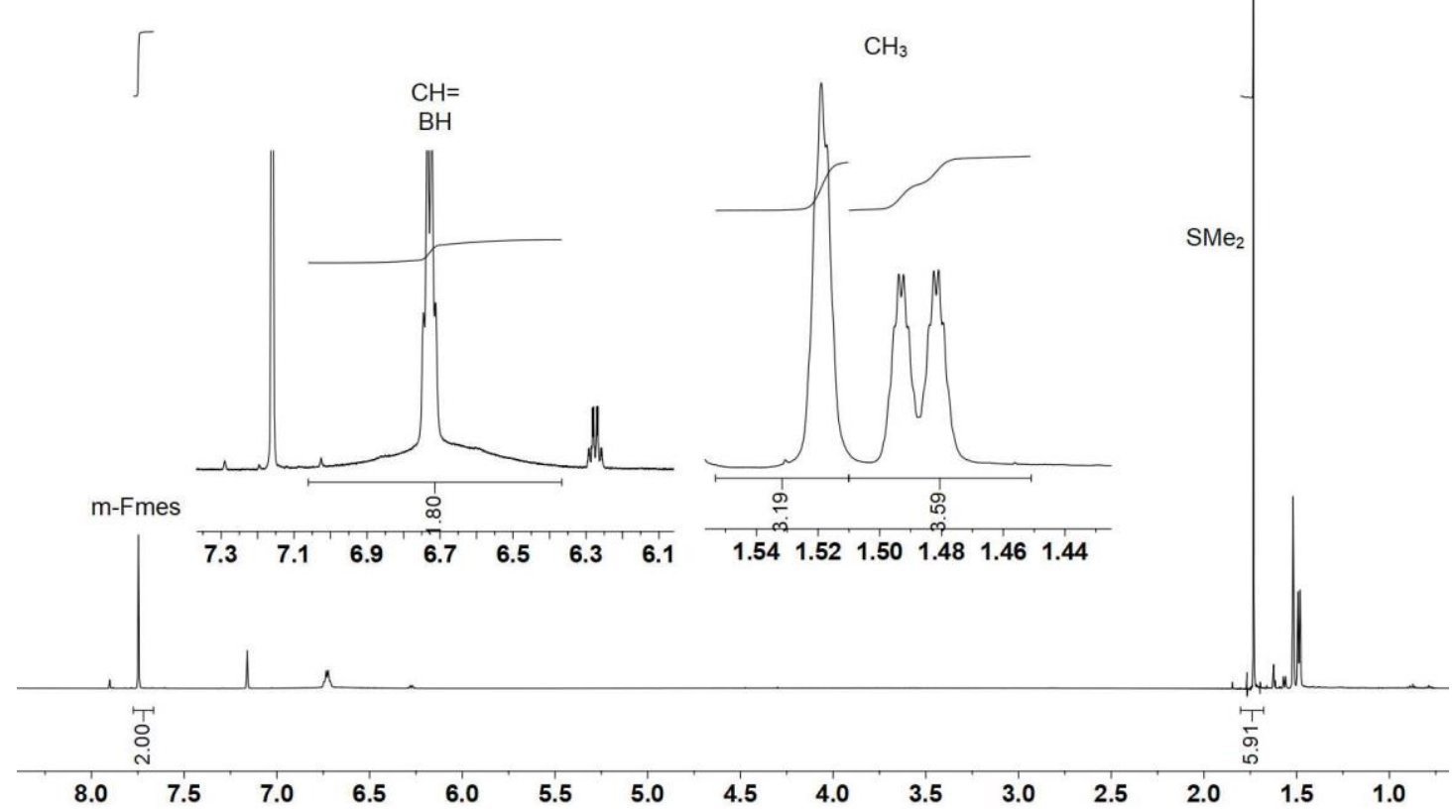

Figure S32. ${ }^{1} \mathrm{H}$ NMR (600 MHz, $\left.\mathrm{C}_{6} \mathrm{D}_{6}, 299 \mathrm{~K}\right)$ spectrum of compound $13 \mathrm{c}$. 


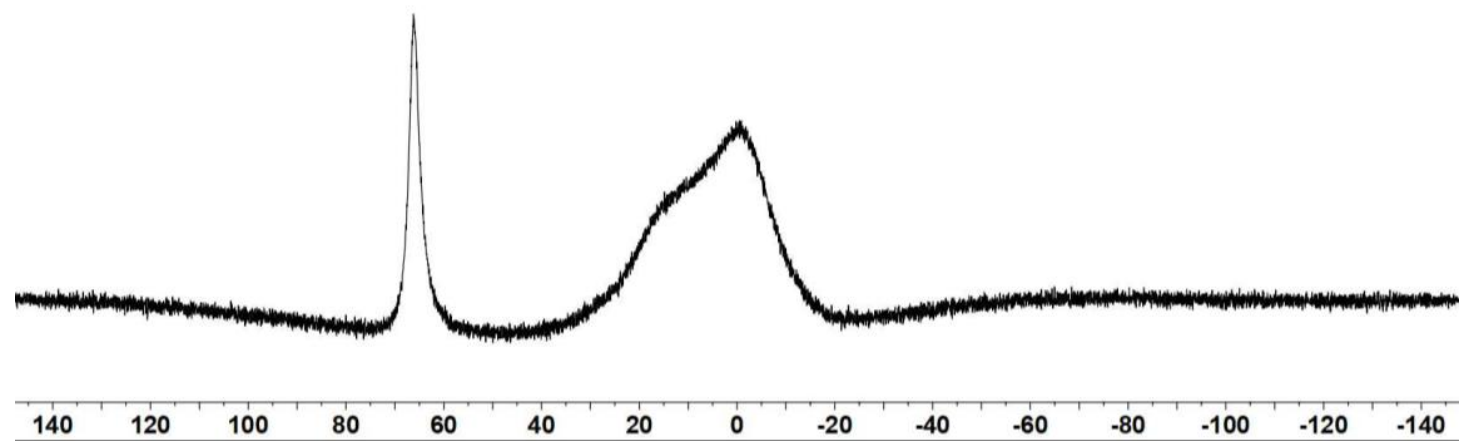

Figure S33. ${ }^{11} \mathrm{~B}$ NMR (192 MHz, $\left.\mathrm{C}_{6} \mathrm{D}_{6}, 299 \mathrm{~K}\right)$ spectrum of compound $13 \mathrm{c}$.

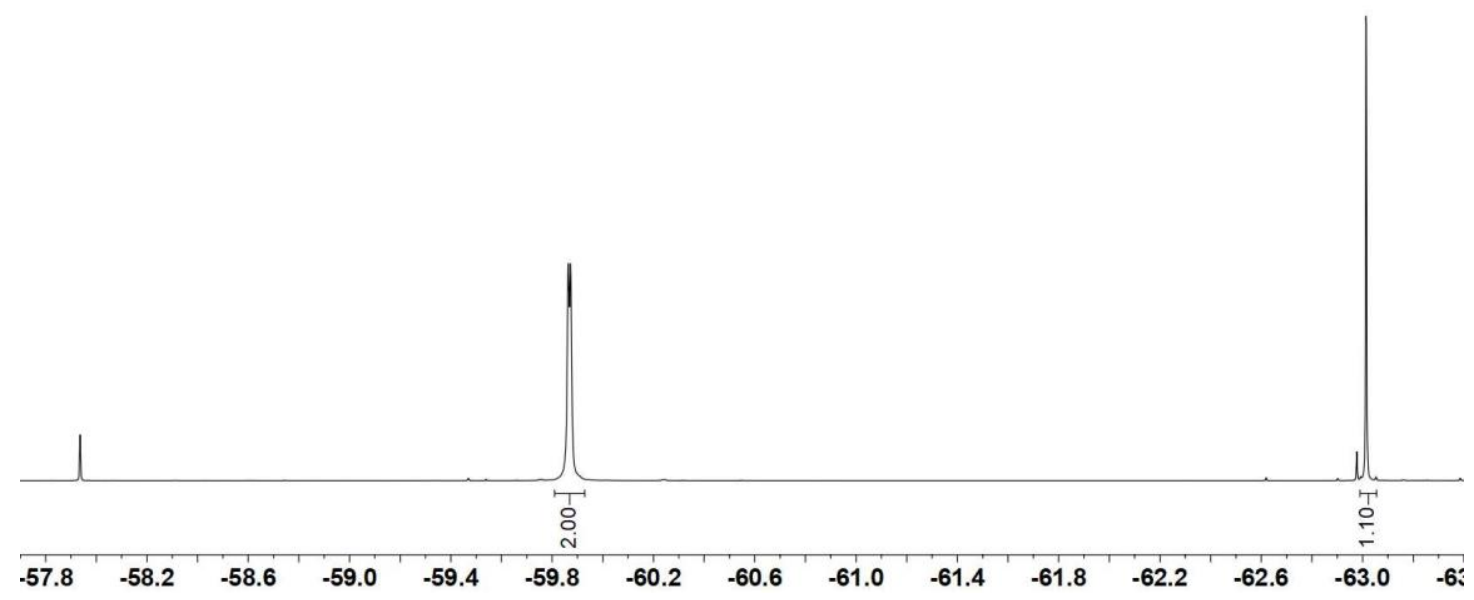

Figure S34. ${ }^{19} \mathrm{~F}$ NMR (564 MHz, $\mathrm{C}_{6} \mathrm{D}_{6}, 299 \mathrm{~K}$ ) spectrum of compound $13 \mathrm{c}$.

Single crystals suitable for the $X$-ray diffraction analysis were obtained from a solution of compound $16 \mathrm{c}$ in pentane at $-35^{\circ} \mathrm{C}$.

X-ray crystal structure analysis of compound 16c (erk9522): A colorless prism-like specimen of $\mathrm{C}_{22} \mathrm{H}_{19} \mathrm{BF} 9 \mathrm{~N}$, approximate dimensions $0.040 \mathrm{~mm} \times 0.080 \mathrm{~mm} \times 0.120 \mathrm{~mm}$, was used for the X-ray crystallographic analysis. The $\mathrm{X}$-ray intensity data were measured. The integration of the data using a monoclinic unit cell yielded a total of 7426 reflections to a maximum $\theta$ angle of $25.00^{\circ}(0.84 \AA$ resolution), of which 3781 were independent (average redundancy 1.964 , completeness $=99.4 \%$, $\left.R_{\text {int }}=4.92 \%, R_{\text {sig }}=4.99 \%\right)$ and $2915(77.10 \%)$ were greater than $2 \sigma\left(F^{2}\right)$. The final cell constants of a $=8.7614(2) \AA, \underline{b}=29.9845(7) \AA, \underline{c}=8.2980(2) \AA, \beta=97.1300(10)^{\circ}$, volume $=2163.08(9) \AA^{3}$, are based upon the refinement of the XYZ-centroids of reflections above $20 \sigma(\mathrm{I})$. Data were corrected 
for absorption effects using the multi-scan method (SADABS). The calculated minimum and maximum transmission coefficients (based on crystal size) are 0.9830 and 0.9940 . The structure was solved and refined using the Bruker SHELXTL Software Package, using the space group $P 2_{1} / c$, with $\mathrm{Z}=4$ for the formula unit, $\mathrm{C}_{22} \mathrm{H}_{19} \mathrm{BF} \mathrm{F}_{9} \mathrm{~N}$. The final anisotropic full-matrix least-squares refinement on $\mathrm{F}^{2}$ with 358 variables converged at $\mathrm{R} 1=7.19 \%$, for the observed data and $\mathrm{WR} 2=$ $20.99 \%$ for all data. The goodness-of-fit was 1.041. The largest peak in the final difference electron density synthesis was $0.335 \mathrm{e}^{-} / \AA^{3}$ and the largest hole was $-0.303 \mathrm{e} / / \AA^{3}$ with an RMS deviation of $0.078 \mathrm{e}^{-} / \AA^{3}$. On the basis of the final model, the calculated density was $1.471 \mathrm{~g} / \mathrm{cm}^{3}$ and $F(000)$, 976 e. CCDC number: 2007636.

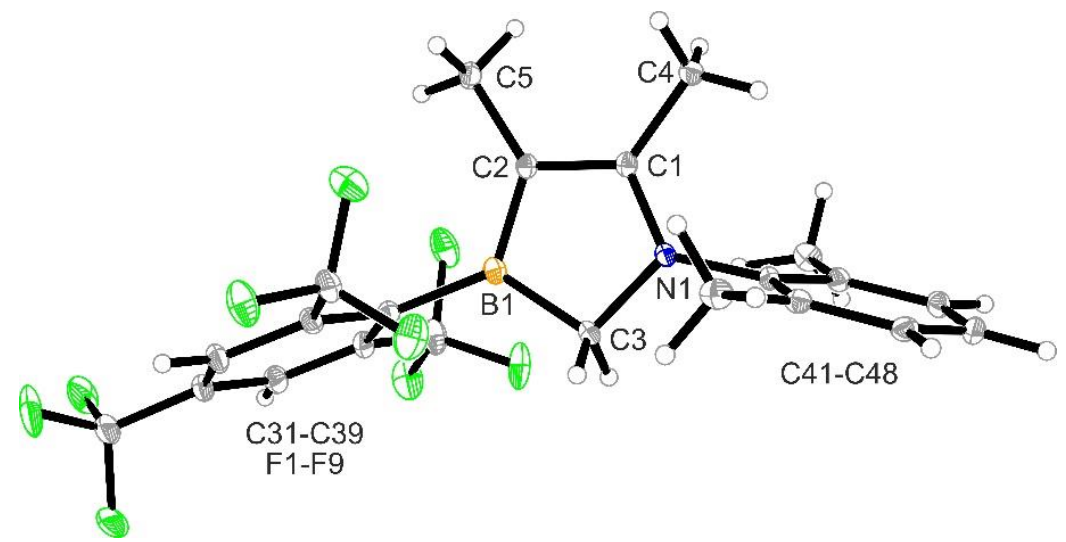

Figure S35. Crystal structure of compound 16c (thermal ellipsoids at 15\% probability).

\section{Preparation of compound 16d}

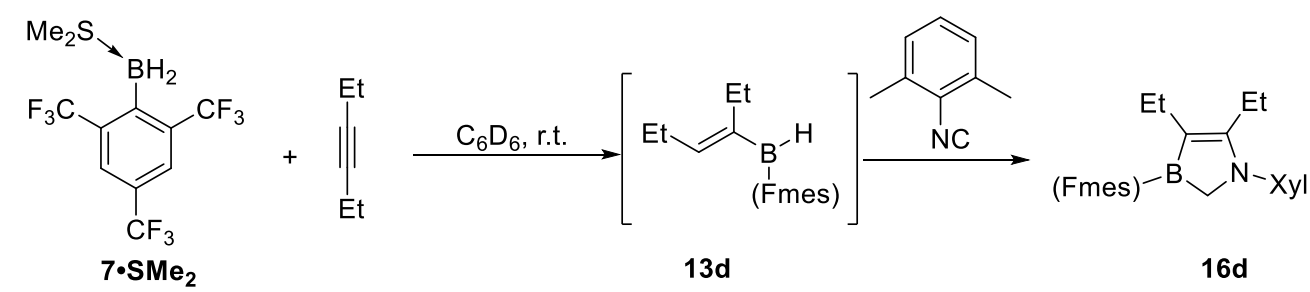

Scheme S8.

At room temperature, borane $7 \mathrm{a} \cdot \mathrm{SMe}_{2}(142.4 \mathrm{mg}, 0.4 \mathrm{mmol}, 1$ eq.) was added to a solution of hex3-yne ( $32.8 \mathrm{mg}, 0.4 \mathrm{mmol}, 1$ eq.) in $\mathrm{C}_{6} \mathrm{D}_{6}(2 \mathrm{~mL})$ under argon atmosphere in a J. Young tube. Then the mixture was stored at room temperature for $30 \mathrm{~min}$ to give a colorless solution. The formation of the hydroboration product was monitored by an in situ NMR experiment. 2,6dimethylphenylisocyanide $(52.4 \mathrm{mg}, 0.4 \mathrm{mmol}, 1 \mathrm{eq}$.) was added to the mixture in one portion to give a brown solution. The resulting solution was stored at room temperature for 2 days. Then all volatiles were removed in vacuo and the residue was purified by column chromatography on silica gel with pentane as the eluents to finally give the compound $16 \mathrm{~d}$ as a light-brown oil (148 $\mathrm{mg}, 73 \%$ yield).

HRMS for $\mathrm{C}_{24} \mathrm{H}_{26} \mathrm{BNF}_{9} \mathrm{O}^{+}\left[\mathrm{M}+\mathrm{H}_{3} \mathrm{O}\right]^{+}$: calc. 526.1963; found: 526.1968.

${ }^{1} \mathrm{H}$ NMR $\left(600 \mathrm{MHz}\right.$, methylene chloride- $\left.d_{2}, 299 \mathrm{~K}\right): \delta=8.11(\mathrm{~s}, 2 \mathrm{H}, m$-Fmes), $7.18(\mathrm{~m}, 1 \mathrm{H}, p-\mathrm{Xyl}), 7.13(\mathrm{~m}$, $\left.2 \mathrm{H}, m-\mathrm{Xyl}), 3.40\left(\mathrm{~m}, 2 \mathrm{H}, \mathrm{CH}_{2}\right), 2.28\left(\mathrm{q},{ }^{3} \mathrm{HHH}_{\mathrm{HH}}=7.6 \mathrm{~Hz}, 2 \mathrm{H}, \mathrm{CH}_{2} \mathrm{~N}\right), 2.22\left(\mathrm{q},{ }^{3}\right)_{\mathrm{HH}}=7.6 \mathrm{~Hz}, 2 \mathrm{H}, \mathrm{CH}_{2}{ }^{\mathrm{B}}\right), 2.14(\mathrm{~s}$, $\left.6 \mathrm{H}, o-\mathrm{CH}_{3}{ }^{\mathrm{XVl}}\right), 1.00\left(\mathrm{t}^{3}{ }^{3} \mathrm{HH}=7.6 \mathrm{~Hz}, 3 \mathrm{H}, \mathrm{CH}_{3} \mathrm{~N}\right), 0.85\left(\mathrm{t},{ }^{3} \mathrm{HH}_{\mathrm{HH}}=7.5 \mathrm{~Hz}, 3 \mathrm{H}, \mathrm{CH}_{3}{ }^{\mathrm{B}}\right)$. 
${ }^{13} \mathrm{C}\left\{{ }^{1} \mathrm{H}\right\}$ NMR (151 MHz, methylene chloride- $\left.d_{2}, 299 \mathrm{~K}\right): \delta=184.2(\mathrm{NC}=), 147.8$ (br, $i$-Fmes), $141.2(i-$ Xyl), 137.7 (o-Xyl), 134.0 (q, $\left.{ }^{2} J_{\mathrm{FC}}=30.7 \mathrm{~Hz}, o-\mathrm{Fmes}\right), 130.1$ (q, ${ }^{2} J_{\mathrm{FC}}=34.1 \mathrm{~Hz}, p$-Fmes), 128.9 ( $m$-Xyl), 128.0 ( $p$-Xyl), 125.7 (br, $m$-Fmes), 124.4 (q, ${ }^{1} J_{\mathrm{FC}}=274.7 \mathrm{~Hz}, o-\mathrm{CF}_{3}{ }^{\mathrm{Fmes}}$ ), $123.8\left(q,{ }^{1} J_{\mathrm{FC}}=272.5 \mathrm{~Hz}, p\right.$ $\left.\mathrm{CF}_{3}{ }^{\mathrm{Fmes}}\right), 121.4(\mathrm{br}, \mathrm{BC}=), 55.4\left(\mathrm{br}, \mathrm{CH}_{2}\right), 21.4\left(\mathrm{CH}_{2}{ }^{\mathrm{N}}\right), 20.4\left(\mathrm{CH}_{2}^{\mathrm{B}}\right), 17.6\left(0-\mathrm{CH}_{3}{ }^{\mathrm{Xyl}}\right), 16.5\left(\mathrm{CH}_{3}{ }^{\mathrm{B}}\right), 12.2$ $\left(\mathrm{CH}_{3}{ }^{\mathrm{N}}\right)$.

${ }^{11} \mathrm{~B}\left\{{ }^{1} \mathrm{H}\right\}$ NMR (192 MHz, methylene chloride- $\left.d_{2}, 299 \mathrm{~K}\right): \delta=58.2\left(\mathrm{v}_{1 / 2} \approx 470 \mathrm{~Hz}\right)$.

${ }^{19} \mathrm{~F} \mathrm{NMR}\left(564 \mathrm{MHz}\right.$, methylene chloride- $\left.d_{2}, 299 \mathrm{~K}\right): \delta=-58.5\left(\mathrm{~s}, 2 \mathrm{~F}, o-\mathrm{CF}_{3}{ }^{\mathrm{Fmes}}\right),-63.5\left(\mathrm{~s}, 1 \mathrm{~F}, p-\mathrm{CF}_{3}{ }^{\mathrm{Fmes}}\right)$.
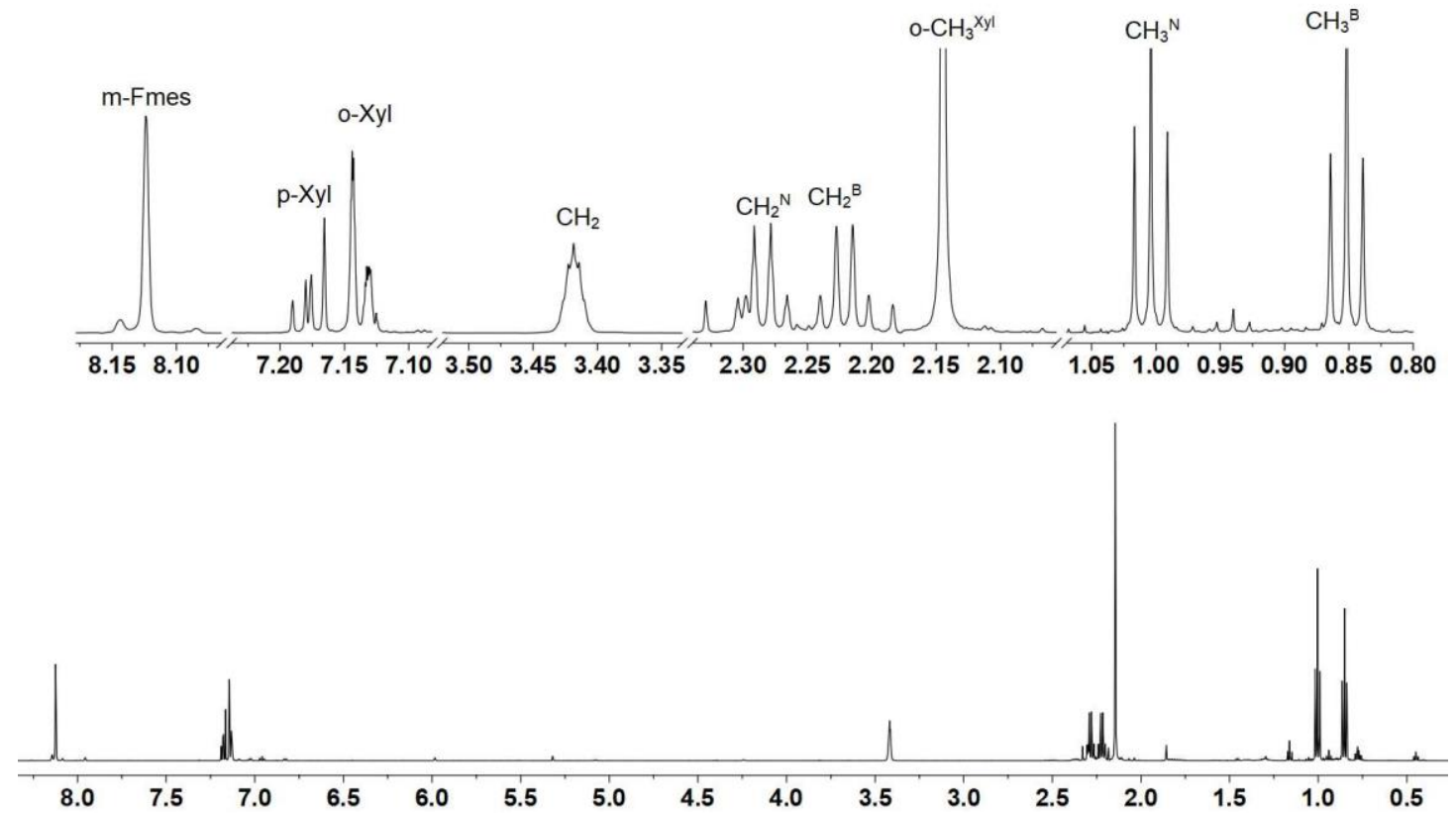

Figure S36. ${ }^{1} \mathrm{H}$ NMR (600 MHz, methylene chloride- $d_{2}, 299 \mathrm{~K}$ ) spectrum of compound $\mathbf{1 6 d .}$

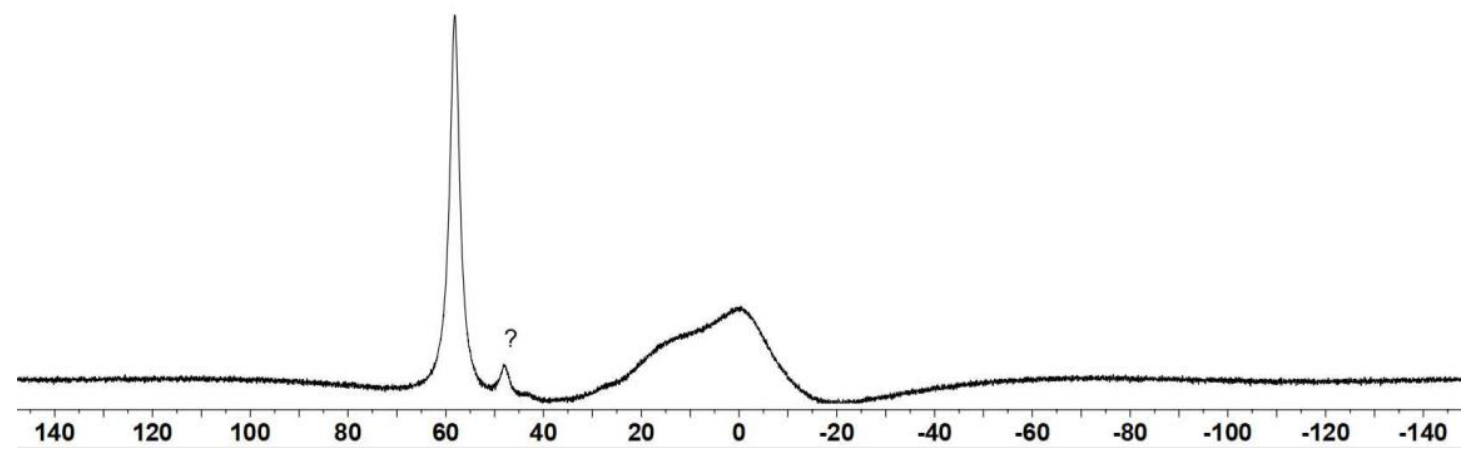

Figure S37. ${ }^{11} \mathrm{~B}\left\{{ }^{1} \mathrm{H}\right\}$ NMR (192 MHz, methylene chloride- $\left.d_{2}, 299 \mathrm{~K}\right)$ spectrum of compound $16 \mathrm{~d}$.

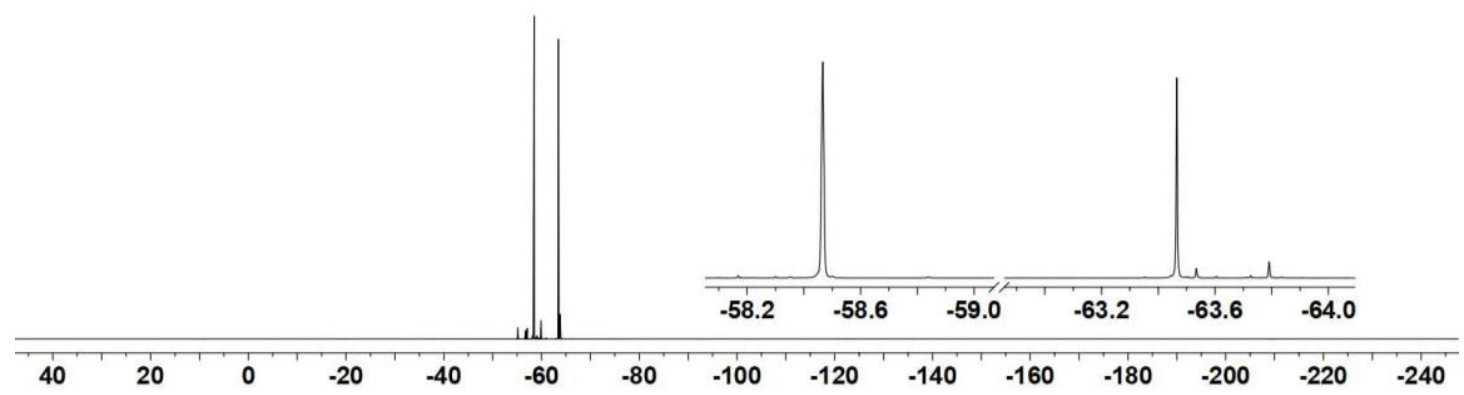

Figure S38. ${ }^{19} \mathrm{~F}$ NMR (564 MHz, methylene chloride- $d_{2}, 299 \mathrm{~K}$ ) spectrum of compound $\mathbf{1 6 d}$. 


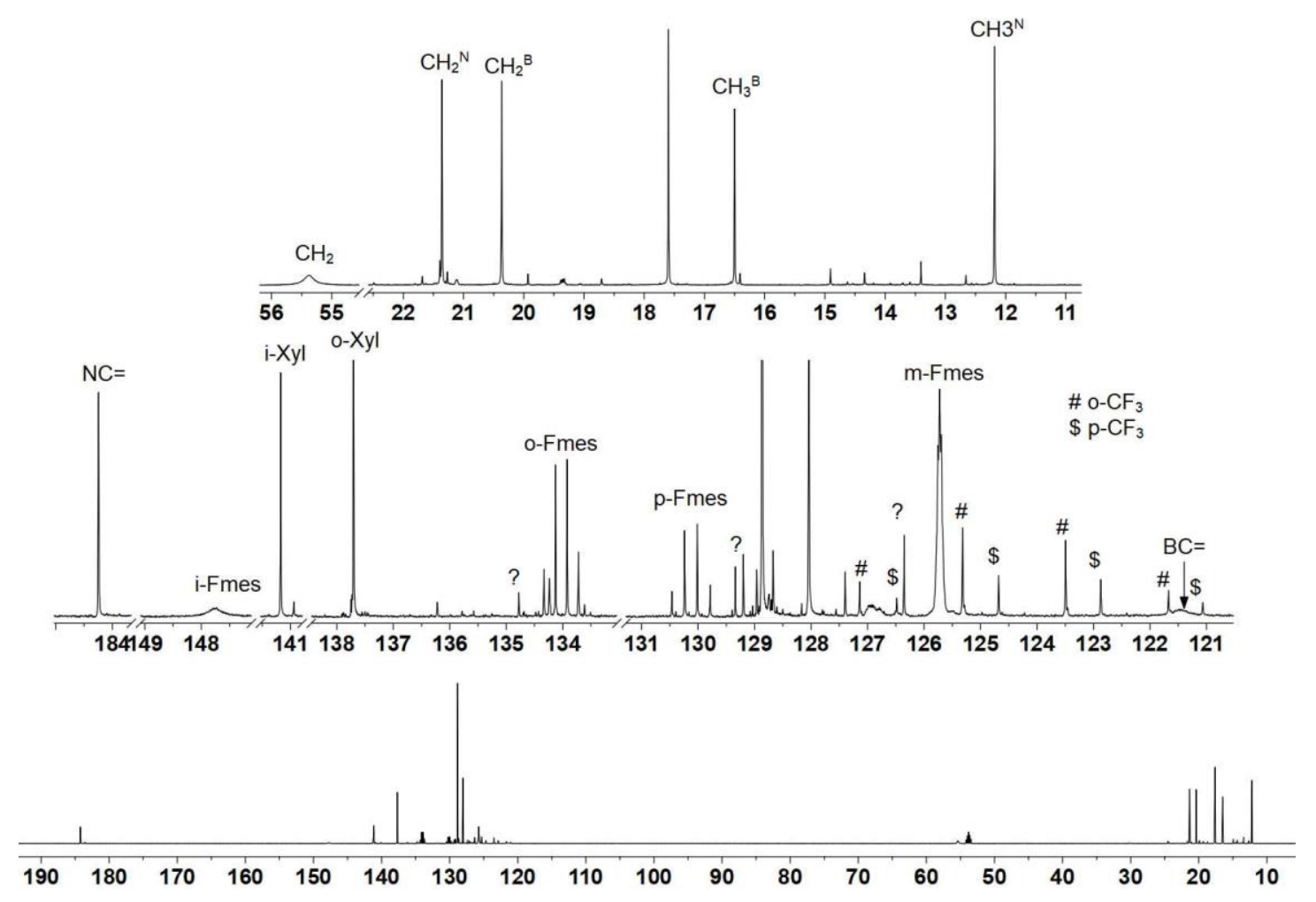

Figure S39. ${ }^{13} \mathrm{C}\left\{{ }^{1} \mathrm{H}\right\} \mathrm{NMR}\left(151 \mathrm{MHz}\right.$, methylene chloride- $\left.d_{2}, 299 \mathrm{~K}\right)$ spectrum of compound $\mathbf{1 6 d}$.

The in situ NMR spectra of the hydroboration product $\mathbf{1 3 d}$ (with a small amount of impurities):

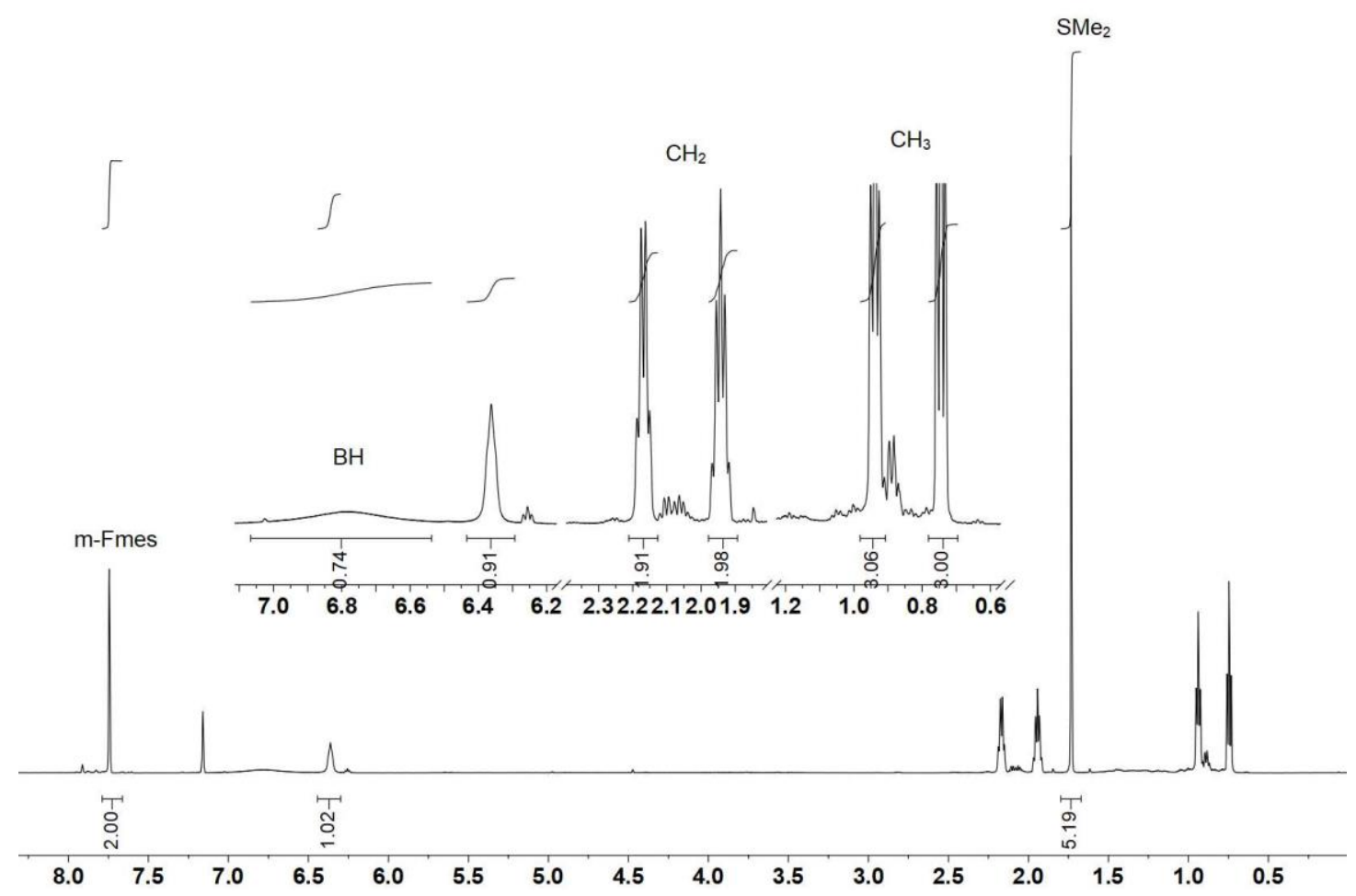

Figure S40. ${ }^{1} \mathrm{H}$ NMR (600 MHz, $\left.\mathrm{C}_{6} \mathrm{D}_{6}, 299 \mathrm{~K}\right)$ spectrum of hydroboration product $13 \mathrm{~d}$. 


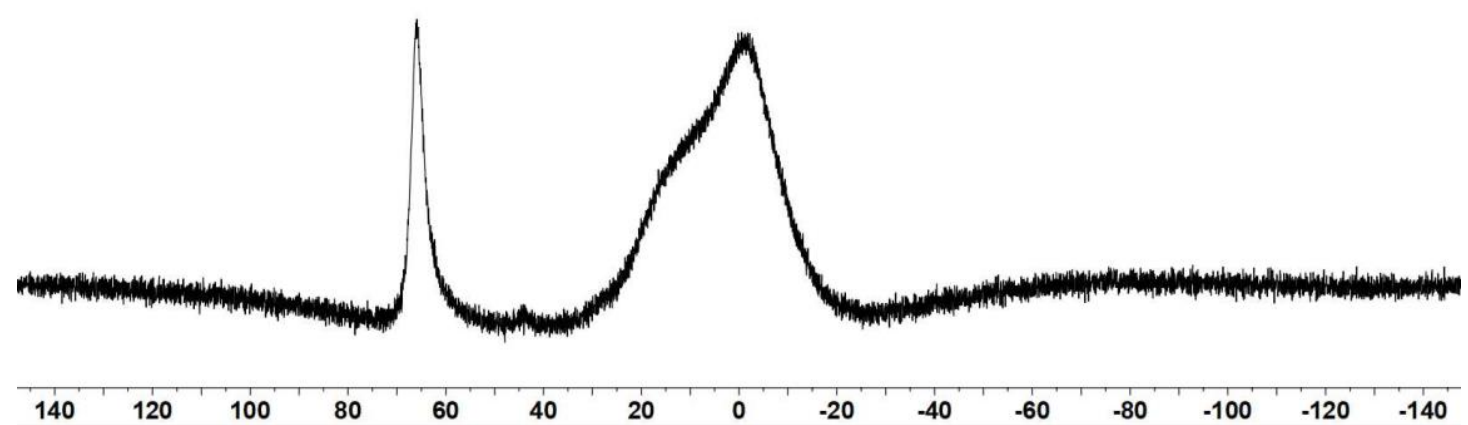

Figure S41. ${ }^{11} \mathrm{~B}$ NMR (192 MHz, $\left.\mathrm{C}_{6} \mathrm{D}_{6}, 299 \mathrm{~K}\right)$ spectrum of hydroboration product $13 \mathrm{~d}$.

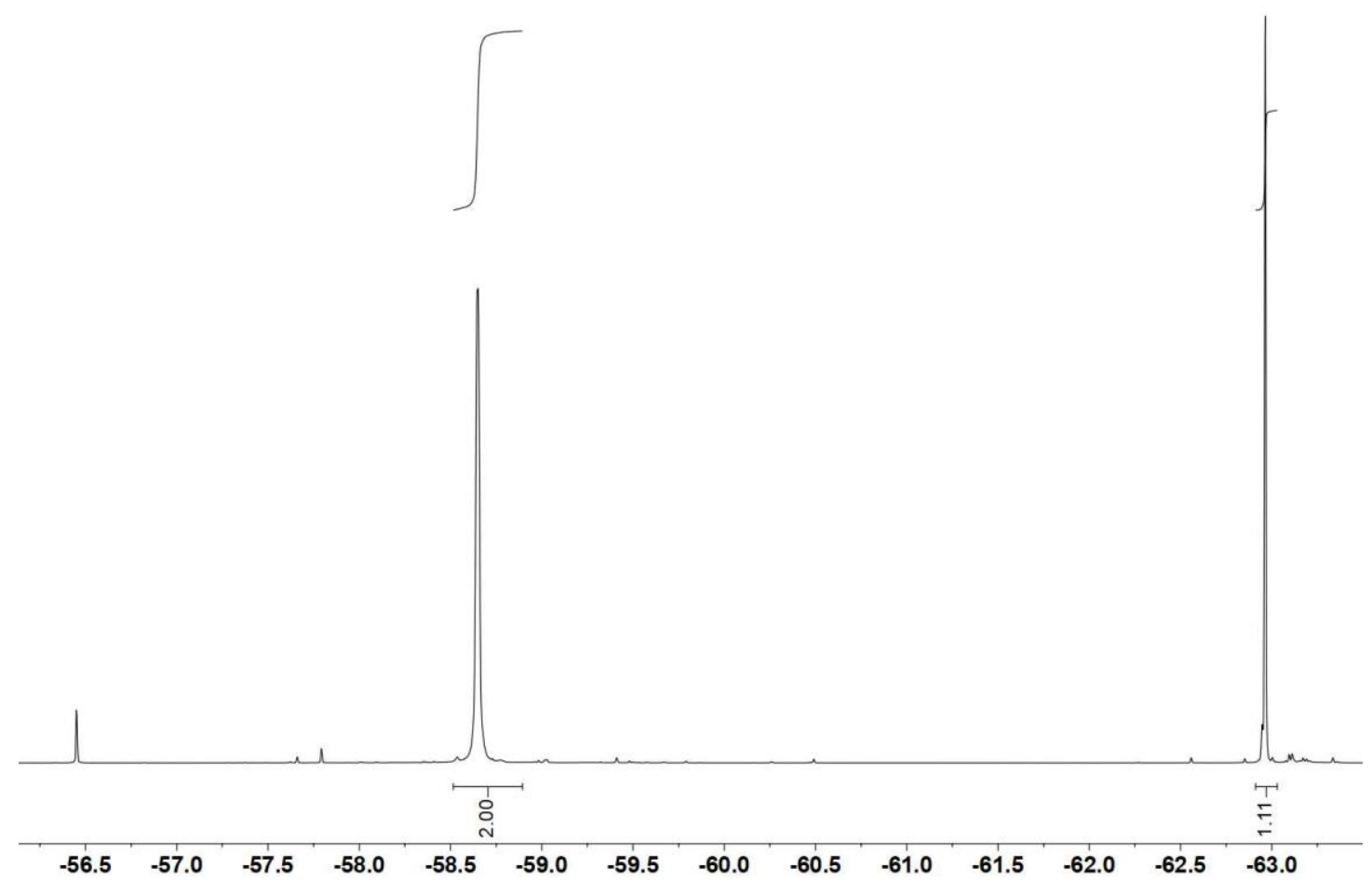

Figure S42. ${ }^{19} \mathrm{~F}$ NMR $\left(564 \mathrm{MHz}, \mathrm{C}_{6} \mathrm{D}_{6}, 299 \mathrm{~K}\right)$ spectrum of hydroboration product $13 \mathrm{~d}$.

Single crystals suitable for $\mathrm{X}$-ray diffraction analysis were obtained from a solution of compound $16 \mathrm{~d}$. in pentane at $-35^{\circ} \mathrm{C}$.

X-ray crystal structure analysis of compound 16d (erk9513): A colorless prism-like specimen of $\mathrm{C}_{24} \mathrm{H}_{23} \mathrm{BF}_{9} \mathrm{~N}$, approximate dimensions $0.120 \mathrm{~mm} \times 0.200 \mathrm{~mm} \times 0.300 \mathrm{~mm}$, was used for the X-ray crystallographic analysis. The $\mathrm{X}$-ray intensity data were measured. The integration of the data using a monoclinic unit cell yielded a total of 9145 reflections to a maximum $\theta$ angle of $25.00^{\circ}(0.84 \AA$ resolution), of which 4711 were independent (average redundancy 1.941 , completeness $=99.1 \%$, $\left.\mathrm{R}_{\text {int }}=4.56 \%, \mathrm{R}_{\mathrm{sig}}=4.54 \%\right)$ and $4088(86.78 \%)$ were greater than $2 \sigma\left(\mathrm{F}^{2}\right)$. The final cell constants of a $=23.0146(5) \AA, \underline{b}=14.3686(3) \AA, \underline{c}=16.8760$ (4) $\AA, \beta=104.4410(10)^{\circ}$, volume $=5404.4(2) \AA^{3}$, are based upon the refinement of the XYZ-centroids of reflections above $20 \sigma(\mathrm{I})$. Data were corrected for absorption effects using the multi-scan method (SADABS). The calculated minimum and 
maximum transmission coefficients (based on crystal size) are 0.9660 and 0.9860 . The structure was solved and refined using the Bruker SHELXTL Software Package, using the space group $C 2 / c$, with $\mathrm{Z}=8$ for the formula unit, $\mathrm{C}_{24} \mathrm{H}_{23} \mathrm{BF}_{9} \mathrm{~N}$. The final anisotropic full-matrix least-squares refinement on $\mathrm{F}^{2}$ with 416 variables converged at $\mathrm{R} 1=8.80 \%$, for the observed data and $\mathrm{wR} 2=$ $24.74 \%$ for all data. The goodness-of-fit was 1.066 . The largest peak in the final difference electron density synthesis was $0.422 \mathrm{e}^{-} / \AA^{3}$ and the largest hole was $-0.438 \mathrm{e}^{-} / \AA^{3}$ with an RMS deviation of $0.097 \mathrm{e}^{-} / \AA^{3}$. On the basis of the final model, the calculated density was $1.247 \mathrm{~g} / \mathrm{cm}^{3}$ and $F(000)$, 2080 e- CCDC: 2007637.

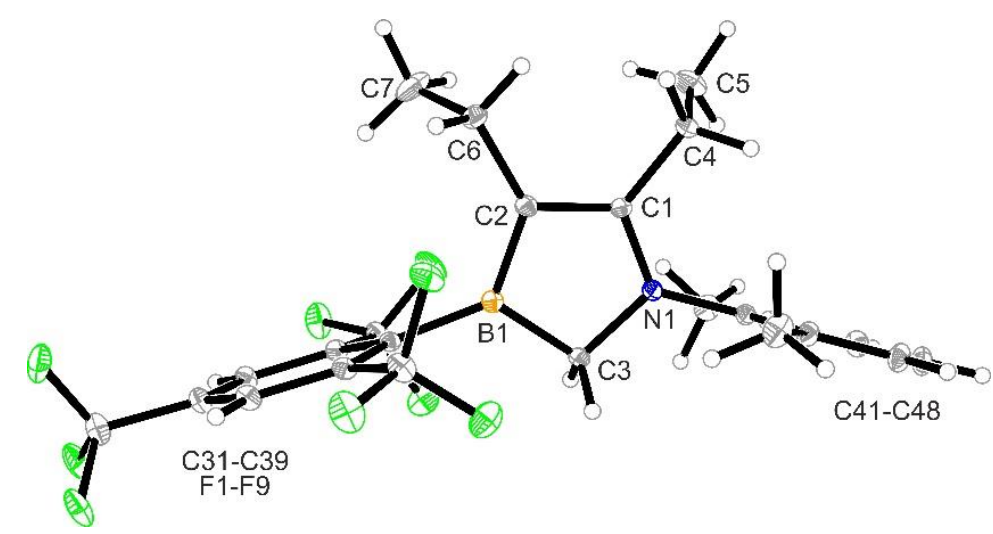

Figure S43. Crystal structure of compound 16d (thermal ellipsoids at 15\% probability).

\section{Preparation of compound 16e.}<smiles>CSc1c(C(F)(F)F)cc(C(F)(F)F)cc1C(F)(F)F</smiles>

$7 \cdot \mathrm{SMe}_{2}$

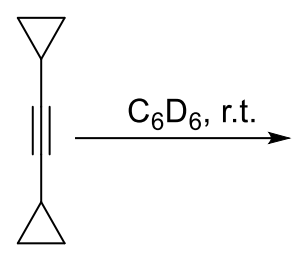<smiles>BC(=CC1CC1)C1CC1</smiles>

$13 e$<smiles>Cc1cccc2cccc(C)c12</smiles>

$(\text { Fmes })^{-B} \vee^{N-X y l}$<smiles>CC(C)[BH2-]B1CN([AlH2])C(C2CC2)=C1C1CC1</smiles>

$16 e$

Scheme 59 .

At room temperature, borane $7 \cdot \mathrm{SMe}_{2}(142.4 \mathrm{mg}, 0.4 \mathrm{mmol}, 1$ eq.) was added to a solution of 1,2dicyclopropylethyne ( $42.4 \mathrm{mg}, 0.4 \mathrm{mmol}, 1$ eq.) in $\mathrm{C}_{6} \mathrm{D}_{6}(2 \mathrm{~mL})$ under argon atmosphere in a J. Young tube. The mixture was stored for 30 min to give a colorless solution. The formation of the hydroboration product $13 \mathrm{e}$ was monitored by an in situ NMR experiment. Then 2.,6dimethylphenyl isocyanide ( $52.4 \mathrm{mg}, 0.4 \mathrm{mmol}, 1 \mathrm{eq}$.) was added to the mixture in one portion to give a brown solution. The resulting solution was stored at room temperature for 2 days. Then all volatiles were removed in vacuo, the residue was dissolved in pentane $(1 \mathrm{~mL})$ and stored at $-35^{\circ} \mathrm{C}$ to finally give the compound $16 \mathrm{e}$ as a light yellow solid (138 $\mathrm{mg}, 65 \%$ yield).

Elemental Analysis for $\mathrm{C}_{26} \mathrm{H}_{23} \mathrm{BNF}$ : calc. C (58.78 \%), H (4.36\%), N (2.64 \%); found: C (57.72\%), H (4.25\%), N (2.50\%);

HRMS for $\mathrm{C}_{26} \mathrm{H}_{26} \mathrm{BNF}_{9} \mathrm{O}^{+}\left[\mathrm{M}+\mathrm{H}_{3} \mathrm{O}\right]^{+}$: calc. 550.1963, found: 550.1967.

${ }^{1} \mathrm{H}$ NMR (600 MHz, methylene chloride- $\left.d_{2}, 299 \mathrm{~K}\right): \delta=8.08(\mathrm{~s}, 2 \mathrm{H}, m$-Fmes), $7.15(\mathrm{~m}, 1 \mathrm{H}, p$-Xyl), $7.11(\mathrm{~m}, 2 \mathrm{H}, m-\mathrm{Xyl}), 3.35\left(\mathrm{~m}, 2 \mathrm{H}, \mathrm{CH}_{2}\right), 2.15\left(\mathrm{~s}, 6 \mathrm{H}, o_{-}-\mathrm{CH}_{3}{ }^{\mathrm{Xyl}}\right), 1.53\left(\mathrm{~m}, 1 \mathrm{H}, \mathrm{CH}^{\mathrm{cpN}}\right), 1.42\left(\mathrm{~m}, 1 \mathrm{H}, \mathrm{CH}^{\mathrm{cpB}}\right)$, 
[1.17, 0.74](each m, each $\left.2 \mathrm{H}, \mathrm{CH}_{2}{ }^{\mathrm{cpN}}\right),[0.38,-0.07]$ (each $\mathrm{m}$, each $2 \mathrm{H}, \mathrm{CH}_{2}{ }^{\mathrm{cPB}}$ ).

${ }^{13} \mathrm{C}\left\{{ }^{1} \mathrm{H}\right\}$ NMR (151 MHz, methylene chloride- $d_{2}, 299 \mathrm{~K}$ ): $\delta=184.2$ (NC=), 148.1 (br, i-Fmes), 141.8 (i-Xyl), 137.4 (o-Xyl), 133.7 (q, $\left.{ }^{2} \mathrm{JFC}_{\mathrm{FC}}=30.6 \mathrm{~Hz}, o-\mathrm{Fmes}\right), 129.9$ (q, ${ }^{2} J_{\mathrm{FC}}=34.0 \mathrm{~Hz}, p$-Fmes), $128.6(\mathrm{~m}$ $\mathrm{Xyl}), 127.9(p-\mathrm{Xyl}), 125.6$ (br, $m$-Fmes), 124.3 (q, $\left.{ }^{1} \mathrm{JFC}_{\mathrm{FC}}=274.8 \mathrm{~Hz}, o-\mathrm{CF}_{3}{ }^{\mathrm{Fmes}}\right), 123.7$ (q, ${ }^{1} \mathrm{JFC}_{\mathrm{FC}}=271.6 \mathrm{~Hz}$, $\left.p-\mathrm{CF}_{3}{ }^{\mathrm{Fmes}}\right), 121.2(\mathrm{br}, \mathrm{BC}=), 55.7\left(\mathrm{br}, \mathrm{CH}_{2}\right), 17.5\left(o-\mathrm{CH}_{3}{ }^{\mathrm{Xyl}}\right), 12.0\left(\mathrm{CH}^{\mathrm{cpN}}\right), 9.1\left(\mathrm{CH}^{\mathrm{cPB}}\right), 7.1\left(\mathrm{CH}_{2}^{\mathrm{cpB}}\right), 6.4$ $\left(\mathrm{CH}_{2}{ }^{\mathrm{cpN}}\right)$.

${ }^{11} \mathrm{~B}\left\{{ }^{1} \mathrm{H}\right\}$ NMR $\left(192 \mathrm{MHz}\right.$, methylene chloride- $\left.d_{2}, 299 \mathrm{~K}\right): \delta=56.6\left(\mathrm{v}_{1 / 2} \approx 380 \mathrm{~Hz}\right)$.

${ }^{19} \mathrm{~F}$ NMR $\left(564 \mathrm{MHz}\right.$, methylene chloride- $\left.d_{2}, 299 \mathrm{~K}\right): \delta=-58.4\left(\mathrm{~s}, 2 \mathrm{~F}, o-\mathrm{CF}_{3}\right),-63.4\left(\mathrm{~s}, 1 \mathrm{~F}, p-\mathrm{CF}_{3}\right)$.

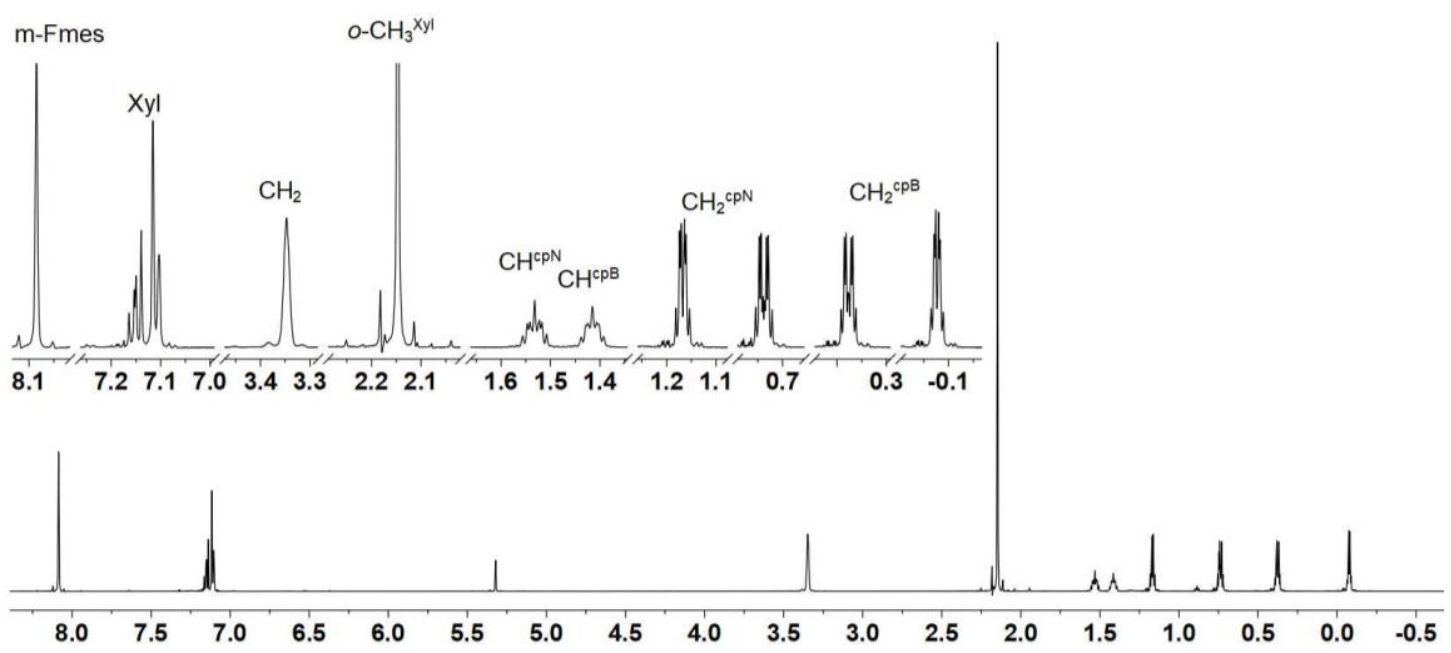

Figure S44. ${ }^{1} \mathrm{H}$ NMR (600 MHz, methylene chloride- $d_{2}, 299 \mathrm{~K}$ ) spectrum of compound 16e.
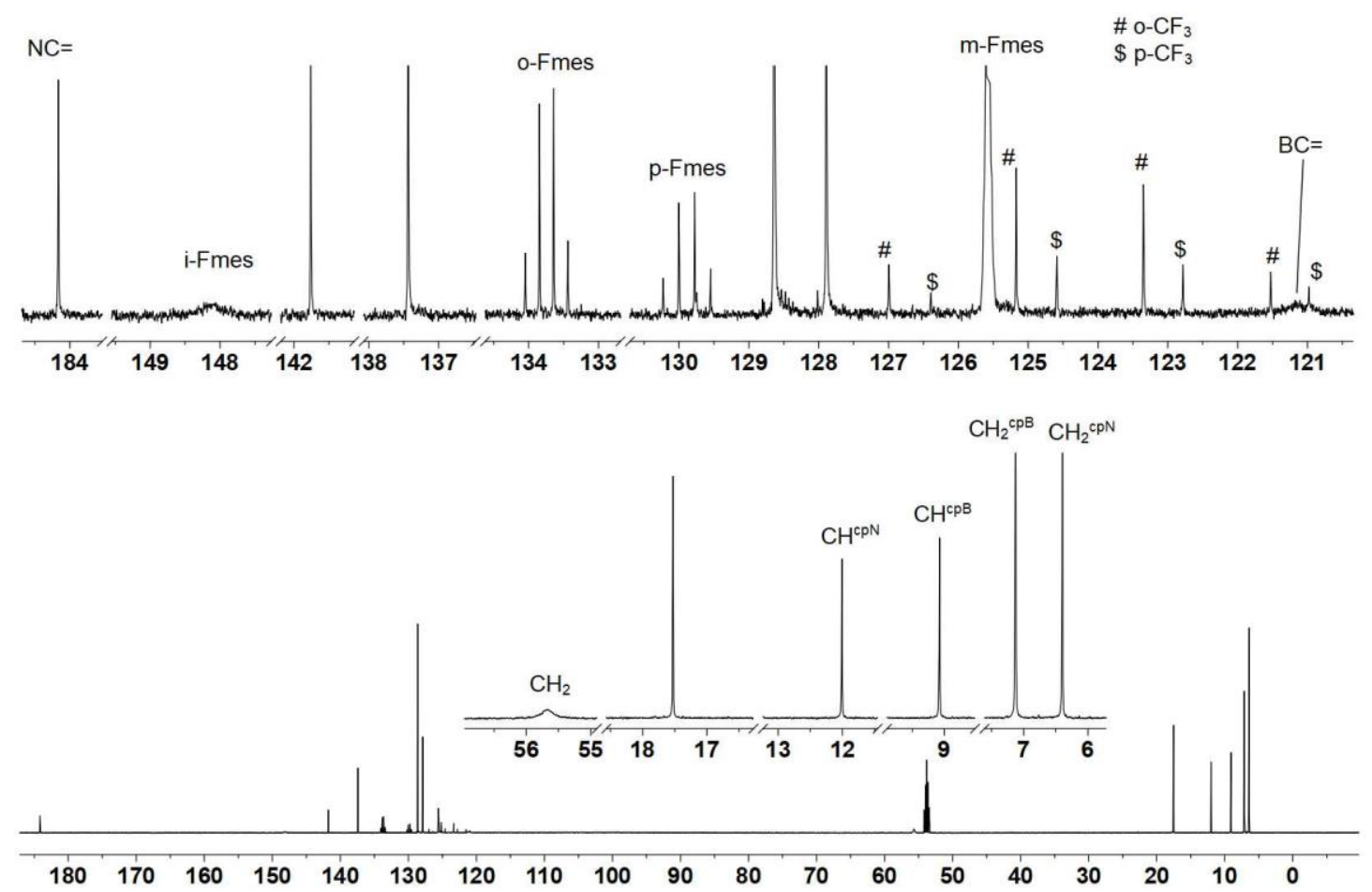

Figure S45. ${ }^{13} \mathrm{C}\left\{{ }^{1} \mathrm{H}\right\} \mathrm{NMR}\left(151 \mathrm{MHz}\right.$, methylene chloride- $\left.d_{2}, 299 \mathrm{~K}\right)$ spectrum of compound $16 \mathrm{e}$. 


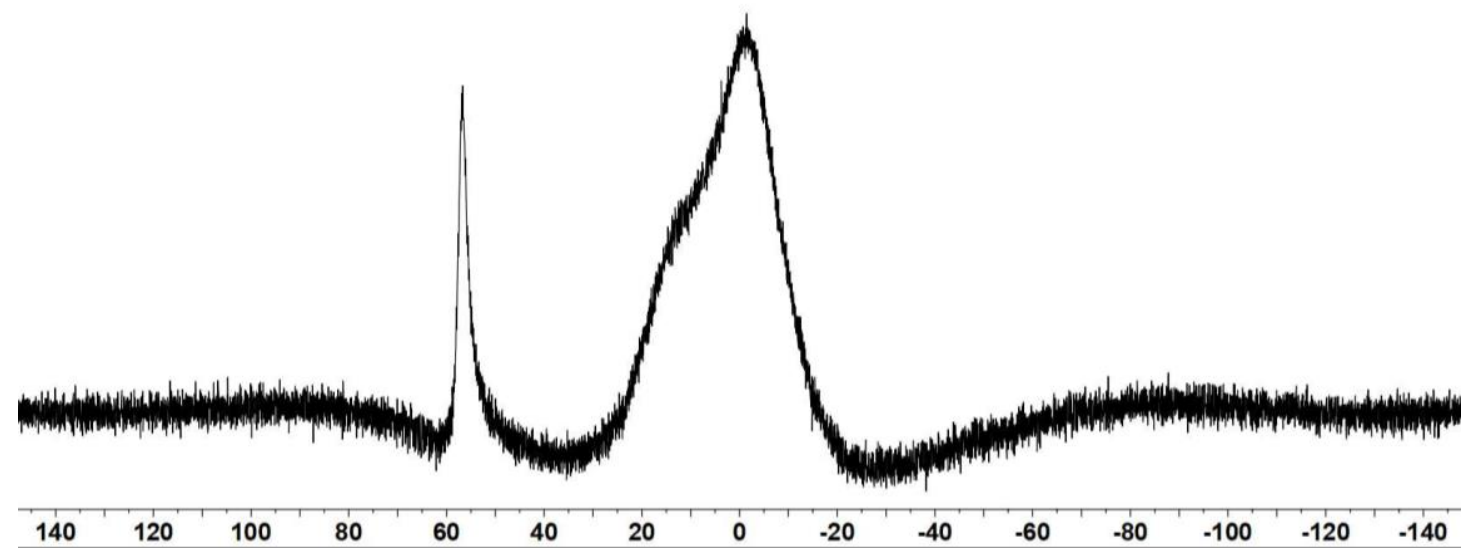

Figure S46. ${ }^{11} \mathrm{~B}\left\{{ }^{1} \mathrm{H}\right\}$ NMR (192 MHz, methylene chloride- $\left.d_{2}, 299 \mathrm{~K}\right)$ spectrum of compound $16 \mathrm{e}$.

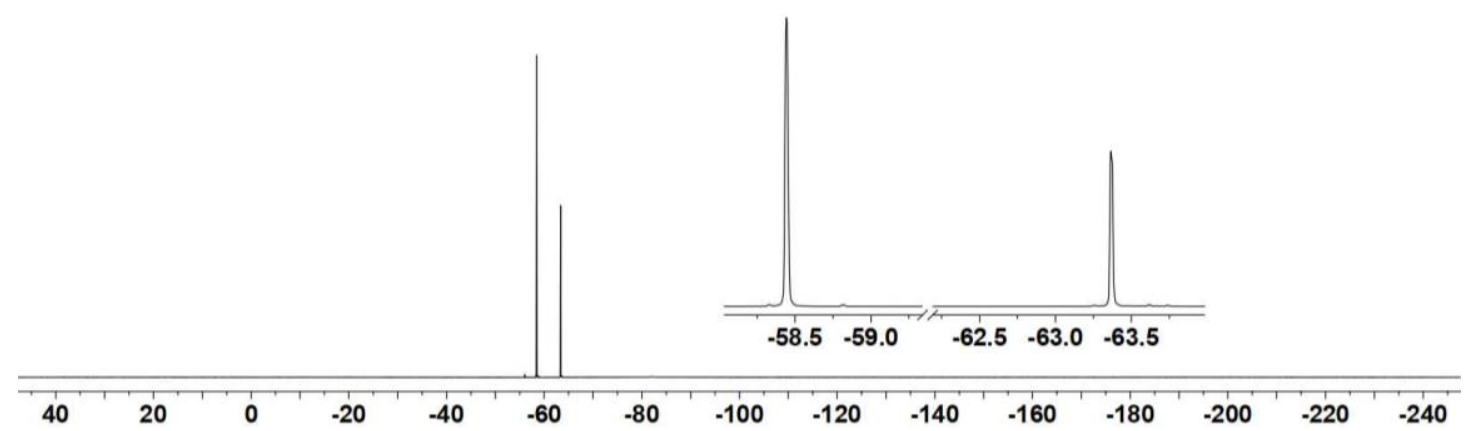

Figure S47. ${ }^{19} \mathrm{~F}$ NMR ( $564 \mathrm{MHz}$, methylene chloride- $d_{2}, 299 \mathrm{~K}$ ) spectrum of compound $16 \mathrm{e}$.

The in situ NMR spectra of the hydroboration product 13e (with small amounts of impurities):

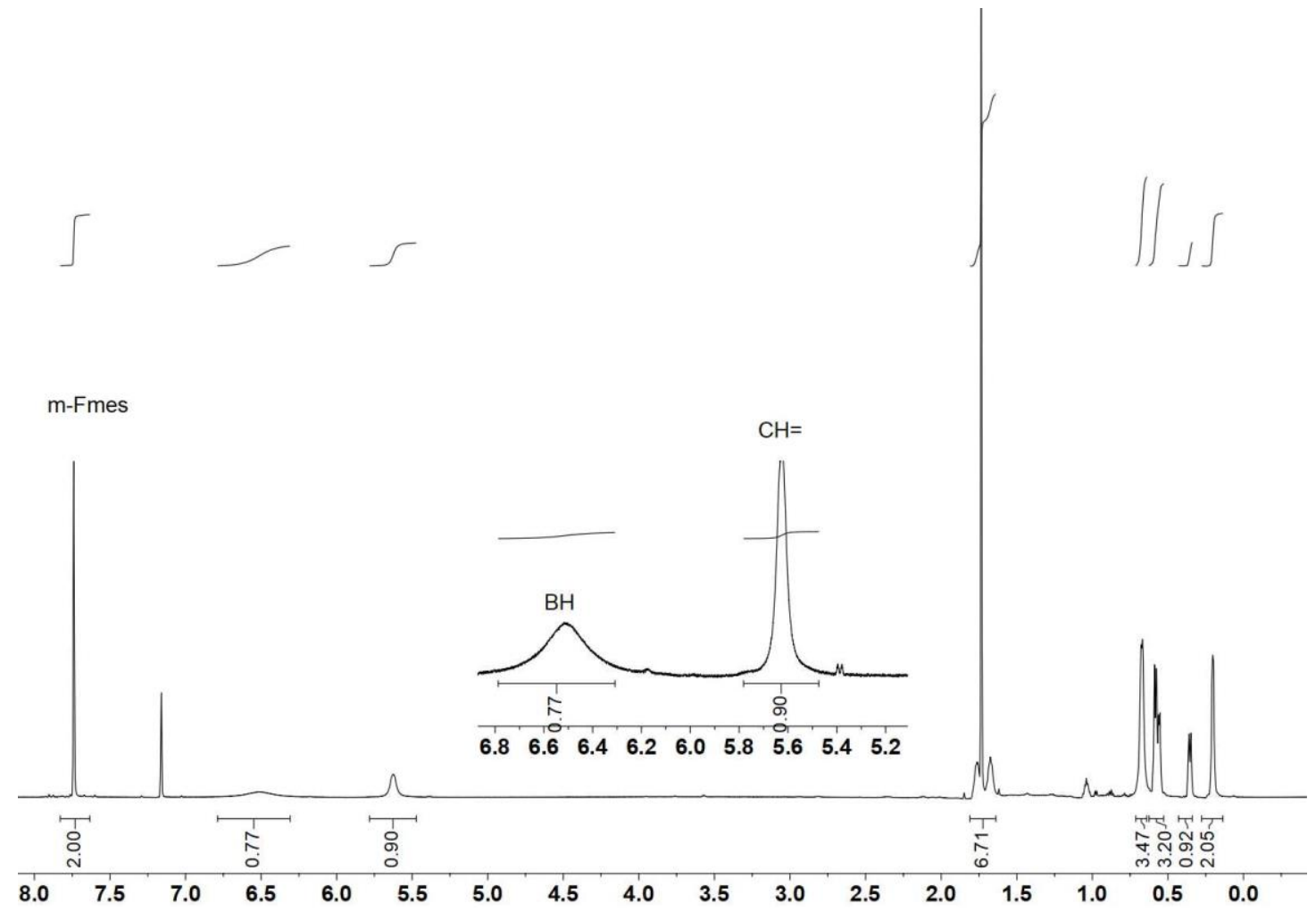

Figure S48. ${ }^{1} \mathrm{H}$ NMR (600 MHz, $\left.\mathrm{C}_{6} \mathrm{D}_{6}, 299 \mathrm{~K}\right)$ spectrum of hydroboration product $13 \mathrm{e}$. 


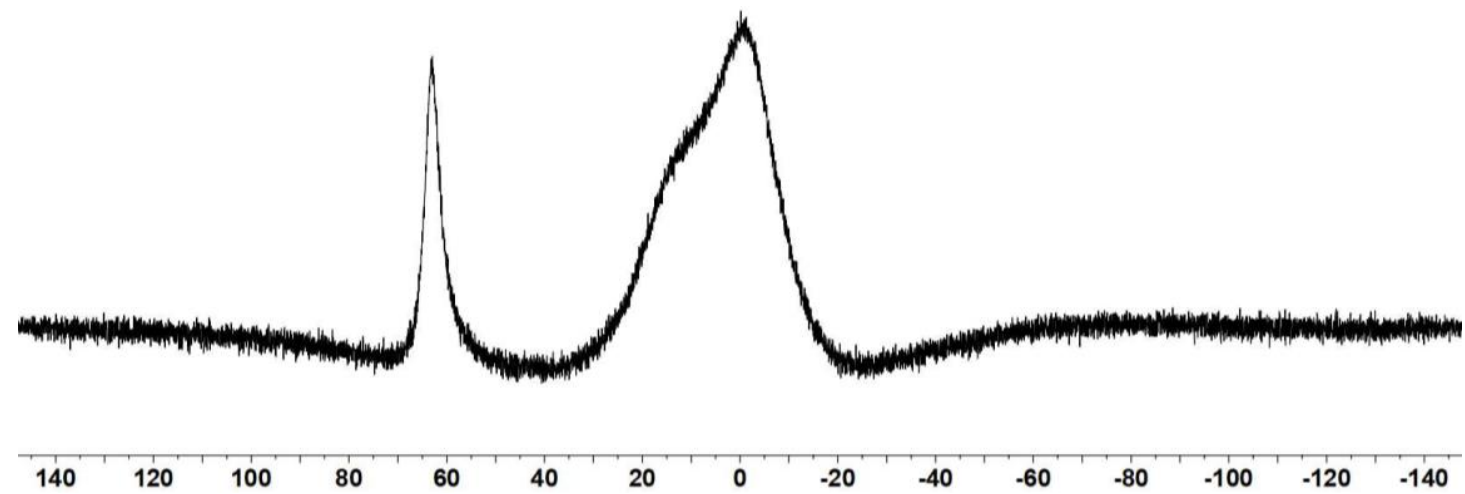

Figure S49. ${ }^{11} \mathrm{~B}$ NMR (192 MHz, $\left.\mathrm{C}_{6} \mathrm{D}_{6}, 299 \mathrm{~K}\right)$ spectrum of hydroboration product $13 \mathrm{e}$.

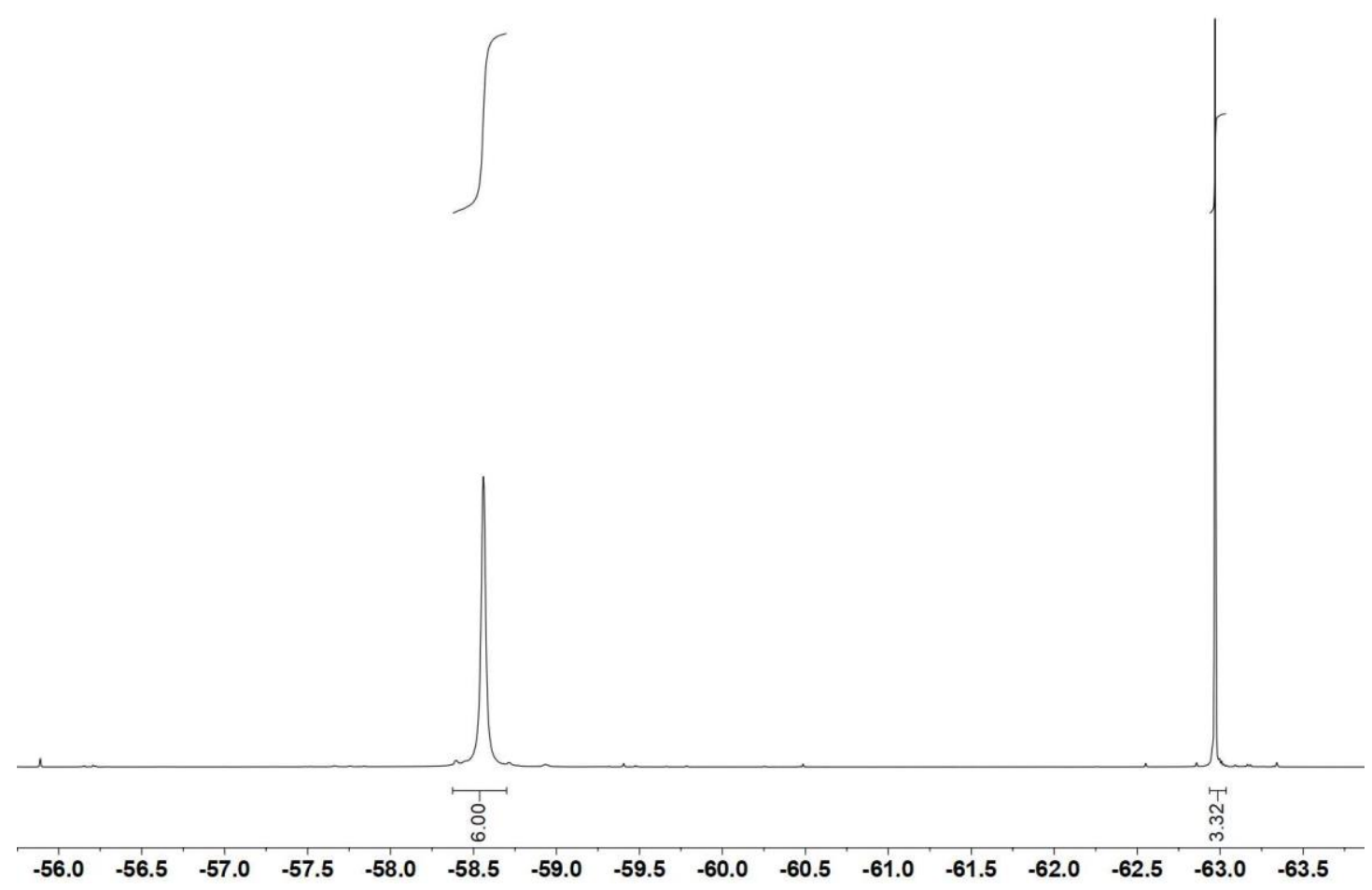

Figure S50. ${ }^{19} \mathrm{~F} \mathrm{NMR} \mathrm{(564} \mathrm{MHz,} \mathrm{C}_{6} \mathrm{D}_{6}, 299 \mathrm{~K}$ ) spectrum of hydroboration product $13 \mathrm{e}$.

Crystals suitable for X-ray diffraction analysis were obtained from a solution of compound $16 \mathrm{e}$ in pentane at $-35^{\circ} \mathrm{C}$.

X-ray crystal structure analysis of compound 16e (erk9560): A colorless prism-like specimen of $\mathrm{C}_{26} \mathrm{H}_{23} \mathrm{BF} \mathrm{F}_{9}$, approximate dimensions $0.160 \mathrm{~mm} \times 0.173 \mathrm{~mm} \times 0.396 \mathrm{~mm}$, was used for the X-ray crystallographic analysis. The X-ray intensity data were measured. A total of 476 frames were collected. The total exposure time was 7.27 hours. The frames were integrated with the Bruker SAINT software package using a narrow-frame algorithm. The integration of the data using a triclinic unit cell yielded a total of 26762 reflections to a maximum $\theta$ angle of $25.03^{\circ}(0.84 \AA$ resolution), of which 26762 were independent (average redundancy 1.000, completeness $=95.7 \%$, $\left.R_{\text {int }}=9.50 \%, R_{\text {sig }}=14.46 \%\right)$ and $13868(51.82 \%)$ were greater than $2 \sigma\left(F^{2}\right)$. The final cell constants of $\underline{a}=12.5513(8) \AA, \underline{b}=19.8452(13) \AA, \underline{c}=21.0373(15) \AA, \alpha=109.234(2)^{\circ}, \beta=94.570(2)^{\circ}, v=$ $93.812(2)^{\circ}$, volume $=4907.8(6) \AA^{3}$, are based upon the refinement of the XYZ-centroids of 9957 reflections above $20 \sigma(\mathrm{I})$ with $4.992^{\circ}<2 \theta<54.22^{\circ}$. Data were corrected for absorption effects using 
the multi-scan method (SADABS). The ratio of minimum to maximum apparent transmission was 0.804 . The calculated minimum and maximum transmission coefficients (based on crystal size) are 0.9500 and 0.9790 . The structure was solved and refined using the Bruker SHELXTL Software Package, using the space group $P-1$, with $Z=8$ for the formula unit, $\mathrm{C}_{26} \mathrm{H}_{23} \mathrm{BF} F_{9} \mathrm{~N}$. The final anisotropic full-matrix least-squares refinement on $\mathrm{F}^{2}$ with 1458 variables converged at $\mathrm{R} 1=8.25 \%$, for the observed data and $\mathrm{WR2}=21.49 \%$ for all data. The goodness-of-fit was 1.005 . The largest peak in the final difference electron density synthesis was $0.387 \mathrm{e}^{-} / \AA^{3}$ and the largest hole was $0.460 \mathrm{e}^{-} / \AA^{3}$ with an RMS deviation of $0.075 \mathrm{e}^{-} / \AA^{3}$. On the basis of the final model, the calculated density was $1.438 \mathrm{~g} / \mathrm{cm}^{3}$ and F(000), $2176 \mathrm{e}$. CCDC number: 2007638.

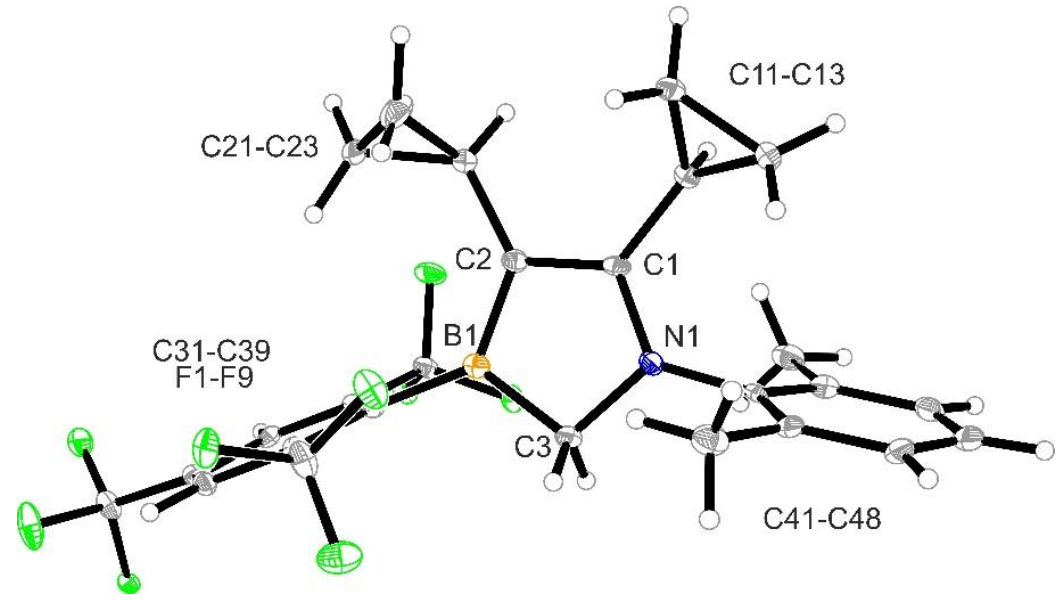

Figure S51. Crystal structure of compound 16e (thermal ellipsoids at 30\% probability).

\section{Preparation of compound $16 f$}

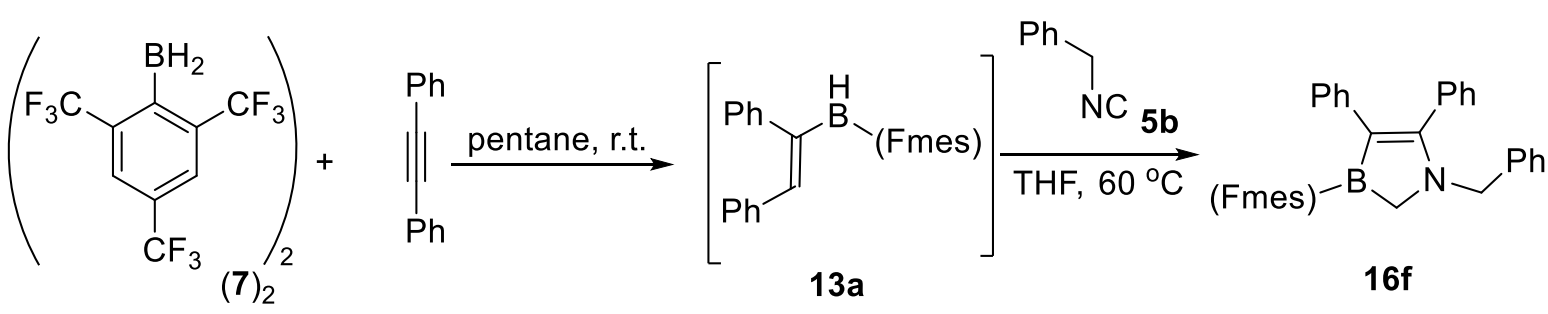

\section{Scheme S10.}

At room temperature, borane (7) $(441 \mathrm{mg}, 1.5 \mathrm{mmol}, 1$ eq.) and diphenylacetylene ( $267 \mathrm{mg}, 1.5$ $\mathrm{mmol}, 1$ eq.) were added subsequently to pentane $(10 \mathrm{~mL})$ under argon atmosphere in a Schlenk tube. The resulting suspension was stirred for $4 \mathrm{~h}$ at room temperature to give a colorless solution. Volatiles were removed in vacuo. The residue was dissolved in THF $(10 \mathrm{~mL})$ and benzyl isocyanide (175.5 mg, $1.5 \mathrm{mmol}, 1$ eq.) was added as one portion to give a yellow solution. The resulting solution was stirred at $60{ }^{\circ} \mathrm{C}$ overnight. Volatiles were removed in vacuo and the residue was purified by column chromatography on silica gel with pentane: dichloromethane (10:1) as eluents to give the compound $\mathbf{1 6 f}$ as white solid (460 $\mathrm{mg}, 52 \%$ yield).

Elemental Analysis for $\mathrm{C}_{31} \mathrm{H}_{21} \mathrm{BNF}_{9}$ : calc. C (63.18\%), $\mathrm{H}(3.59 \%), \mathrm{N}(2.38 \%)$; found: $\mathrm{C}(63.13 \%), \mathrm{H}$ (3.59\%), N (2.22\%);

${ }^{1} \mathrm{H}$ NMR $\left(600 \mathrm{MHz}\right.$, methylene chloride- $\left.d_{2}, 299 \mathrm{~K}\right): \delta=8.07\left(\mathrm{~s}, 2 \mathrm{H}, m\right.$-Fmes), $7.36\left(\mathrm{~m}, 7 \mathrm{H}, o-\mathrm{Ph}^{\mathrm{N}}, m\right.$ $\left.\mathrm{Ph}^{N}, p-\mathrm{Ph}^{N}, m-\mathrm{Ph}^{B \mathrm{Bn}}\right), 7.29\left(\mathrm{~m}, 1 \mathrm{H}, p-\mathrm{Ph}^{\mathrm{Bn}}\right), 7.13\left(\mathrm{~m}, 2 \mathrm{H}, o-\mathrm{Ph}^{\mathrm{Bn}}\right), 6.88\left(\mathrm{~m}, 2 \mathrm{H}, m-\mathrm{Ph}^{\mathrm{B}}\right), 6.83(\mathrm{~m}, 1 \mathrm{H}, p-$ 
$\left.\mathrm{Ph}^{\mathrm{B}}\right), 6.68\left(\mathrm{~m}, 2 \mathrm{H}, \mathrm{o}-\mathrm{Ph}^{\mathrm{B}}\right), 4.67\left(\mathrm{~s}, 2 \mathrm{H}, \mathrm{CH}_{2}{ }^{\mathrm{Bn}}\right), 3.55$ (sept., $\mathrm{J}_{\mathrm{FH}}=2.5 \mathrm{~Hz}, 2 \mathrm{H}, \mathrm{CH}_{2}$ ).

${ }^{13} \mathrm{C}\left\{{ }^{1} \mathrm{H}\right\}$ NMR (151 MHz, methylenechloride- $\left.d_{2}, 299 \mathrm{~K}\right): \delta=180.4$ (NC=), 145.9 (br, $i$-Fmes), $140.2(i-$ $\left.\mathrm{Ph}^{\mathrm{B}}\right), 138.6\left(i-\mathrm{Ph}^{\mathrm{Bn}}\right), 134.02\left(\mathrm{q},{ }^{2} J_{\mathrm{FC}}=31.1 \mathrm{~Hz}, o-F m e s\right), 133.99\left(i-\mathrm{Ph}^{\mathrm{N}}\right), 130.4\left(\mathrm{q},{ }^{2} \mathrm{~J}_{\mathrm{FC}}=34.2 \mathrm{~Hz}, o-\right.$ Fmes), $129.6\left(p-\mathrm{Ph}^{\mathrm{N}}\right), 129.34\left(o-\mathrm{Ph}^{\mathrm{N}}\right), 129.32\left(o-\mathrm{Ph}^{\mathrm{B}}\right), 129.1\left(m-\mathrm{Ph}^{\mathrm{Bn}}\right), 128.9\left(m-\mathrm{Ph}^{\mathrm{N}}\right), 127.7\left(p-\mathrm{Ph}^{\mathrm{Bn}}\right)$, $127.6\left(m-\mathrm{Ph}^{\mathrm{B}}\right), 127.0\left(o-\mathrm{Ph}^{\mathrm{Bn}}\right), 125.9$ (br, $m$-Fmes), $124.2\left(\mathrm{q},{ }^{1} \mathrm{JFC}_{\mathrm{FC}}=275.2 \mathrm{~Hz}, o-\mathrm{CF}_{3}{ }^{\mathrm{Fmes}}\right), 123.9\left(p-\mathrm{Ph}^{\mathrm{B}}\right)$ $123.8(\mathrm{br}, \mathrm{BC}=), 123.5\left(\mathrm{q},{ }^{1} \mathrm{JFC}_{\mathrm{FC}}=272.2 \mathrm{~Hz}, p-\mathrm{CF}_{3}{ }^{\mathrm{Fmes}}\right), 54.3\left(\mathrm{br}, \mathrm{CH}_{2}\right), 53.3\left(\mathrm{CH}_{2}{ }^{\mathrm{Bn}}\right)$.

${ }^{11} \mathrm{~B}\left\{{ }^{1} \mathrm{H}\right\}$ NMR $\left(192 \mathrm{MHz}\right.$, methylene chloride- $\left.d_{2}, 299 \mathrm{~K}\right): \delta=58.8\left(\mathrm{v}_{1 / 2} \approx 720 \mathrm{~Hz}\right)$.

${ }^{19} \mathrm{~F}$ NMR $\left(564 \mathrm{MHz}\right.$, methylene chloride- $\left.d_{2}, 299 \mathrm{~K}\right): \delta=-58.4\left(\mathrm{t}, \mathrm{J}_{\mathrm{HF}}=2.5 \mathrm{~Hz}, 2 \mathrm{~F}, o-\mathrm{CF}_{3}\right),-63.5(\mathrm{~s}, 1 \mathrm{~F}$, $\left.p-\mathrm{CF}_{3}\right)$.
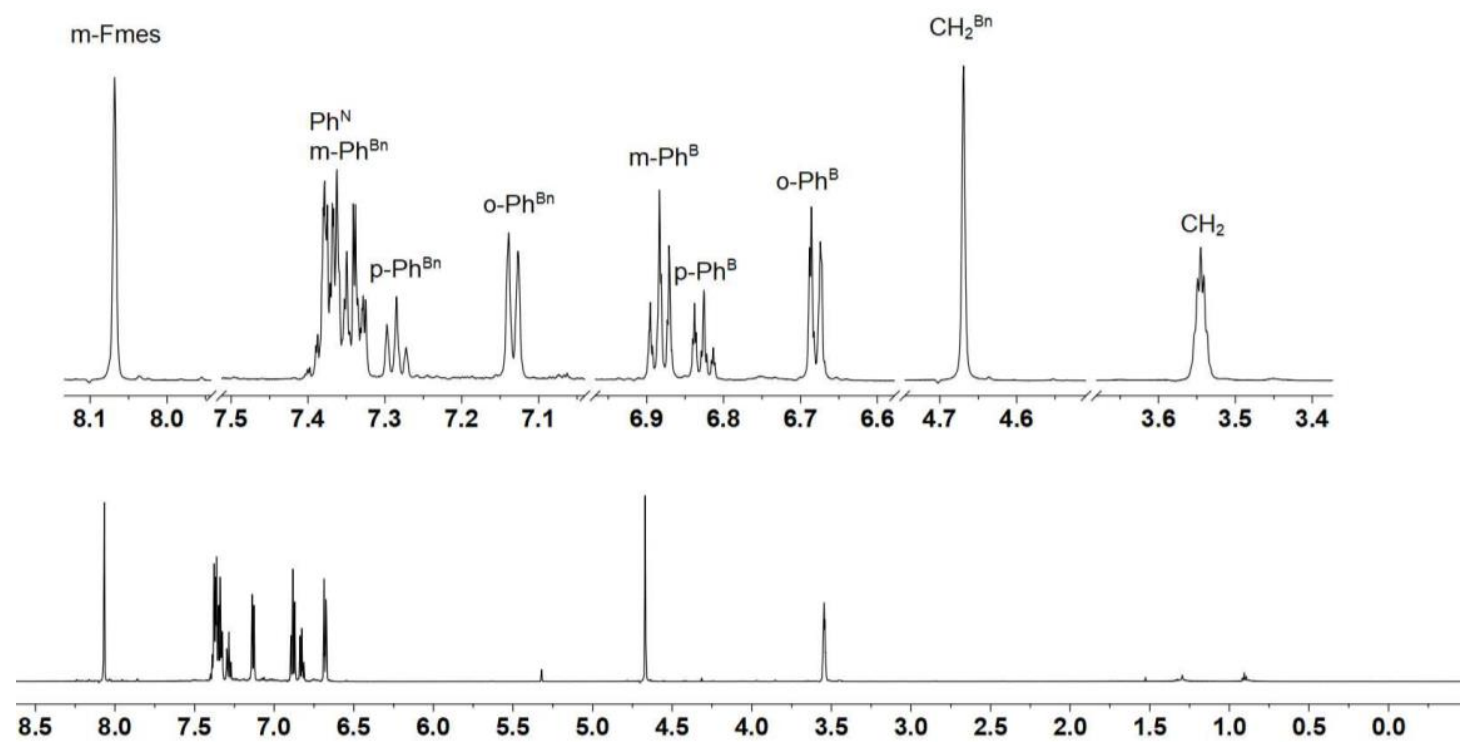

Figure S52. ${ }^{1} \mathrm{H}$ NMR (600 MHz, methylene chloride- $d_{2}, 299 \mathrm{~K}$ ) spectrum of compound $\mathbf{1 6 f .}$

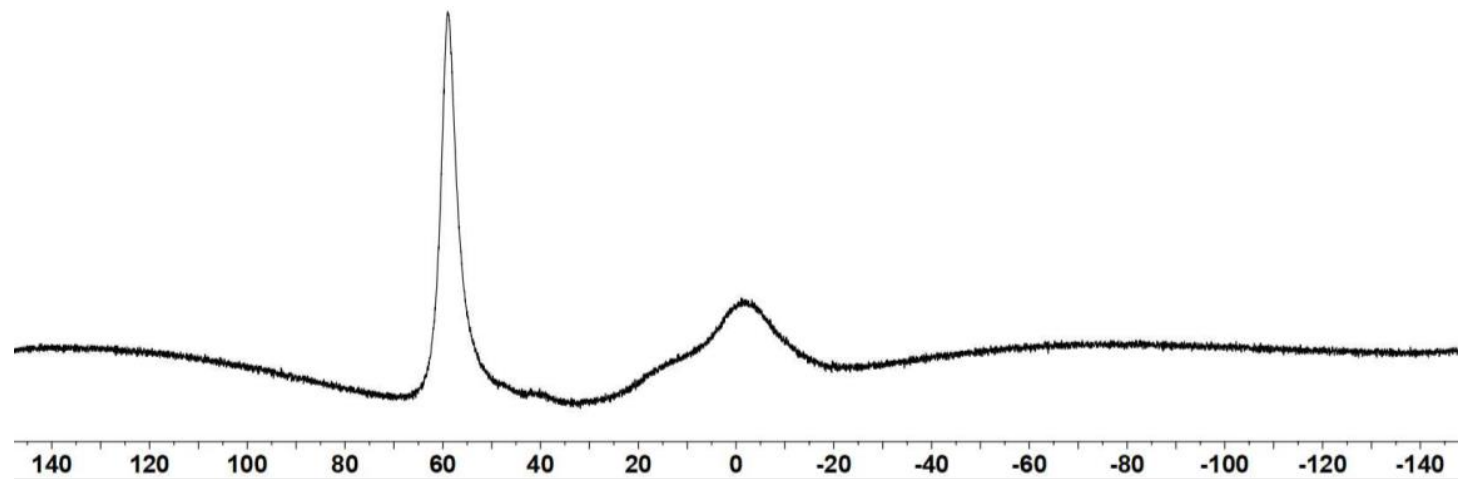

Figure S53. ${ }^{11} \mathrm{~B}\left\{{ }^{1} \mathrm{H}\right\}$ NMR (192 MHz, methylene chloride- $d_{2}, 299 \mathrm{~K}$ ) spectrum of compound $\mathbf{1 6 f .}$

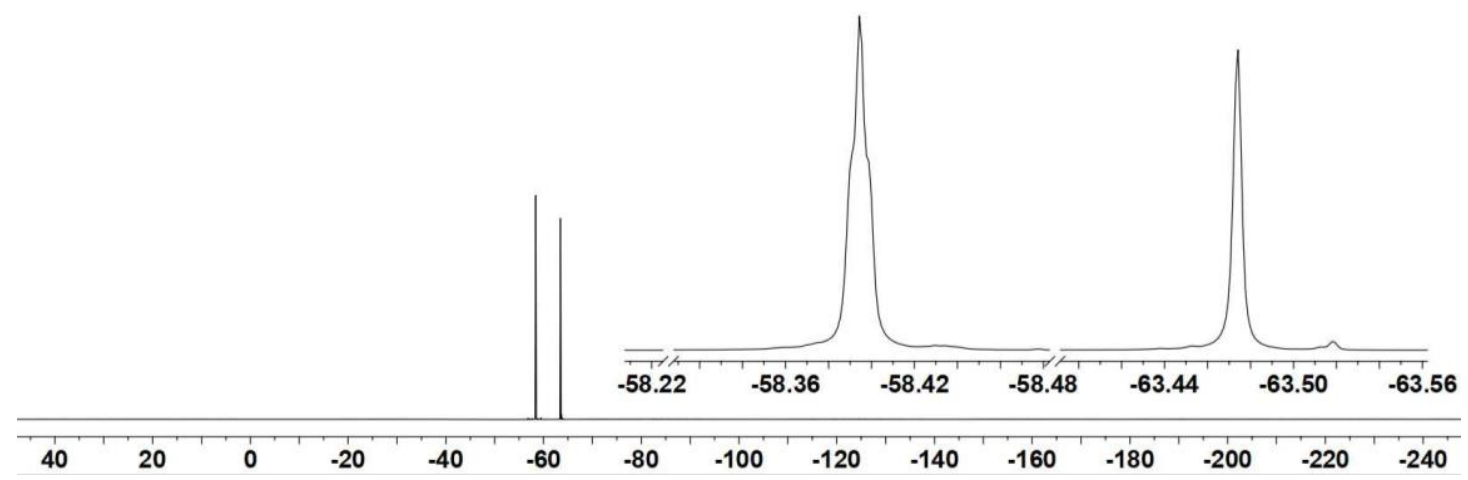

Figure S54. ${ }^{19} \mathrm{~F}$ NMR (564 MHz, methylene chloride- $d_{2}, 299 \mathrm{~K}$ ) spectrum of compound $\mathbf{1 6 f}$. 


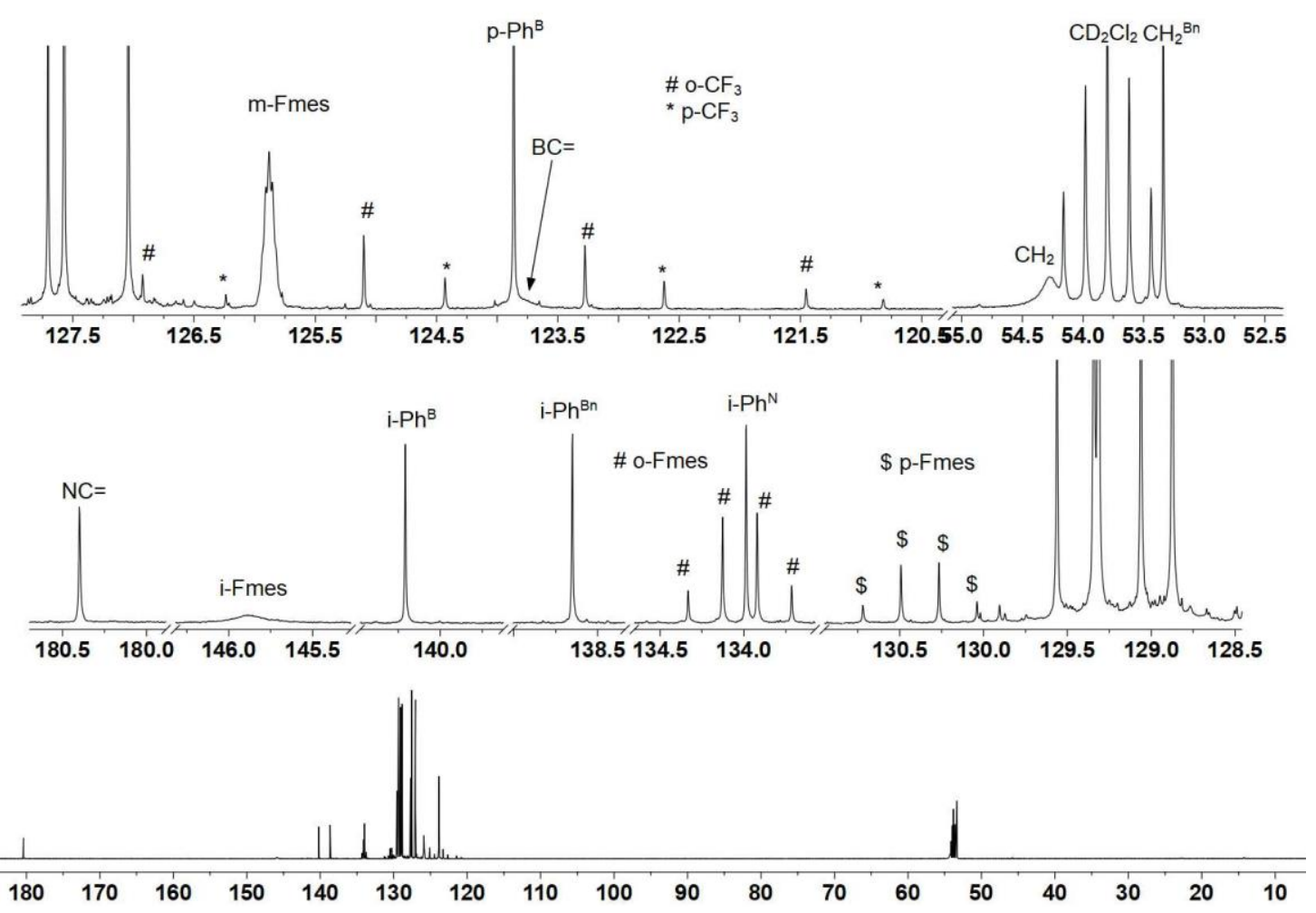

Figure S55. ${ }^{13} \mathrm{C}\left\{{ }^{1} \mathrm{H}\right\}$ NMR (151 MHz, methylene chloride- $d_{2}, 299 \mathrm{~K}$ ) spectrum of compound $\mathbf{1 6 f}$.

Crystals suitable for the X-ray diffraction analysis were obtained from a solution of compound $\mathbf{1 6 f}$ in pentane at $-35^{\circ} \mathrm{C}$.

X-ray crystal structure analysis of compound 16f (erk9729): A colorless prism-like specimen of $\mathrm{C}_{31} \mathrm{H}_{21} \mathrm{BF} 9 \mathrm{~N}$, approximate dimensions $0.092 \mathrm{~mm} \times 0.140 \mathrm{~mm} \times 0.148 \mathrm{~mm}$, was used for the X-ray crystallographic analysis. The X-ray intensity data were measured. A total of 468 frames were collected. The total exposure time was 3.25 hours. The frames were integrated with the Bruker SAINT software package using a narrow-frame algorithm. The integration of the data using a monoclinic unit cell yielded a total of 52881 reflections to a maximum $\theta$ angle of $27.58^{\circ}(0.77 \AA$ resolution), of which 6117 were independent (average redundancy 8.645, completeness $=99.4 \%$, $\left.\mathrm{R}_{\text {int }}=5.50 \%, \mathrm{R}_{\text {sig }}=2.65 \%\right)$ and $5196(84.94 \%)$ were greater than $2 \sigma\left(\mathrm{F}^{2}\right)$. The final cell constants of $\underline{a}$ $=8.0098(2) \AA, \underline{b}=15.6527(4) \AA, \underline{c}=21.2837(5) \AA, \beta=96.4280(10)^{\circ}$, volume $=2651.67(11) \AA^{3}$, are based upon the refinement of the XYZ-centroids of 9908 reflections above $20 \sigma(I)$ with $4.648^{\circ}<2 \theta$ $<55.14^{\circ}$. Data were corrected for absorption effects using the multi-scan method (SADABS). The ratio of minimum to maximum apparent transmission was 0.953 . The calculated minimum and maximum transmission coefficients (based on crystal size) are 0.9810 and 0.9880 . The structure was solved and refined using the Bruker SHELXTL Software Package, using the space group $P 2_{1} / c$, with $Z=4$ for the formula unit, $\mathrm{C}_{31} \mathrm{H}_{21} \mathrm{BF} \mathrm{F}_{9} \mathrm{~N}$. The final anisotropic full-matrix least-squares refinement on $\mathrm{F}^{2}$ with 379 variables converged at $\mathrm{R} 1=4.71 \%$, for the observed data and $\mathrm{wR} 2=$ $11.16 \%$ for all data. The goodness-of-fit was 1.057 . The largest peak in the final difference electron density synthesis was $0.558 \mathrm{e}^{-} / \AA^{3}$ and the largest hole was $-0.423 \mathrm{e} / / \AA^{3}$ with an RMS deviation of $0.052 \mathrm{e}^{-} / \AA^{3}$. On the basis of the final model, the calculated density was $1.476 \mathrm{~g} / \mathrm{cm}^{3}$ and $F(000)$, $1200 \mathrm{e}^{-}$. CCDC number: 2007639. 


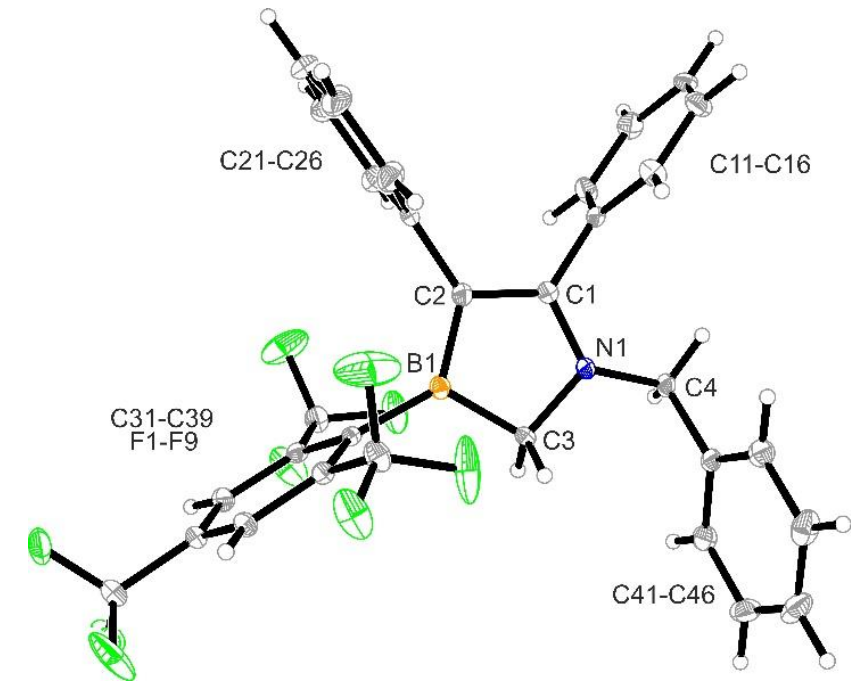

Figure S56. Crystal structure of compound $\mathbf{1 6 f}$ (thermal ellipsoids at 50\% probability).

\section{Preparation of compound 15g.}<smiles>CSc1c(C(F)(F)F)cc(C(F)(F)F)cc1C(F)(F)F</smiles>

$7 \cdot \mathrm{SMe}_{2}$

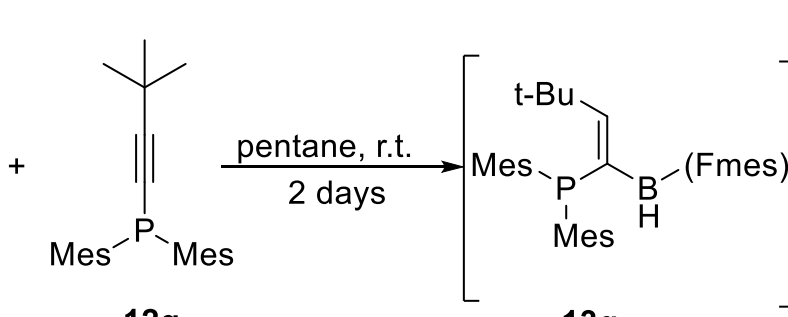

$13 \mathrm{~g}$

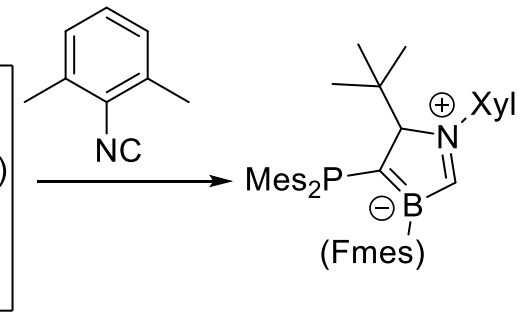

$15 \mathrm{~g}$

Scheme S11.

At room temperature, borane $\mathbf{7} \cdot \mathrm{SMe}_{2}(71.2 \mathrm{mg}, 2 \mathrm{mmol}, 1$ eq.) was added to a solution of phosphane $12 \mathrm{~g}$ (70 mg, $2 \mathrm{mmol}, 1$ eq.) in pentane ( $5 \mathrm{~mL}$ ) under argon atmosphere. The mixture was stirred for 2 days to give a yellow solution. The 2,6-dimethylphenyl isocyanide ( $26.2 \mathrm{mg}, 2$ $\mathrm{mmol}, 1$ eq.) was added to the mixture in one portion to give a dark violet solution. The resulting solution was stored at $-35^{\circ} \mathrm{C}$ to finally give the compound $15 \mathrm{~g}$ as a violet crystalline solid ( $89 \mathrm{mg}$, $57 \%$ yield).

Elemental Analysis for $\mathrm{C}_{42} \mathrm{H}_{44} \mathrm{BNF} 9 \mathrm{P}$ : calc. C (65.04 \%), $\mathrm{H}(5.72 \%), \mathrm{N}(1.81 \%)$; found: $\mathrm{C}(65.43 \%)$, $\mathrm{H}(5.92 \%), \mathrm{N}(2.05 \%)$

${ }^{1} \mathrm{H}$ NMR $\left(600 \mathrm{MHz}\right.$, benzene- $\left.d_{6}, 299 \mathrm{~K}\right): \delta=7.83\left(\mathrm{~s}, 1 \mathrm{H}, m\right.$-Fmes), $7.73(\mathrm{~s}, 1 \mathrm{H}, \mathrm{CH}=), 7.61\left(\mathrm{~s}, 1 \mathrm{H}, m^{\prime}-\right.$ Fmes), $6.86\left(\mathrm{~s}, 1 \mathrm{H}, m-\mathrm{Mes}^{\mathrm{a}}\right), 6.84\left(\mathrm{t},{ }^{3} J_{\mathrm{HH}}=7.4 \mathrm{~Hz}, 1 \mathrm{H}, p\right.$-Xyl), $6.73\left(\mathrm{~d},{ }^{3} \mathrm{~J}_{\mathrm{HH}}=8.6 \mathrm{~Hz}, 1 \mathrm{H}, m-\mathrm{Xyl}\right), 6.72$ $\left(\mathrm{d},{ }^{3} \mathrm{~J}_{\mathrm{HH}}=8.3 \mathrm{~Hz}, 1 \mathrm{H}, m^{\prime}-\mathrm{Xyl}\right), 6.60\left(\mathrm{~d}, J=5.7 \mathrm{~Hz}, 2 \mathrm{H}, m^{\prime}-\mathrm{Mes}^{\mathrm{a}}, m-\mathrm{Mes}^{\mathrm{b}}\right), 5.96\left(\mathrm{~s}, 1 \mathrm{H}, m^{\prime}-\mathrm{Mes}^{\mathrm{b}}\right), 5.28$ $\left(\mathrm{s}, 1 \mathrm{H}, \mathrm{CH}^{\mathrm{t}-\mathrm{Bu}}\right), 2.94\left(\mathrm{~s}, 3 \mathrm{H}, o-\mathrm{CH}_{3}{ }^{\text {Mesb }}\right), 2.88\left(\mathrm{~s}, 3 \mathrm{H}, o-\mathrm{CH}_{3}{ }^{\text {Mesa }}\right), 2.24\left(\mathrm{~s}, 3 \mathrm{H}, o^{\prime}-\mathrm{CH}_{3}{ }^{\text {Mesa }}\right), 2.10(\mathrm{~s}, 6 \mathrm{H}, p-$ $\left.\mathrm{CH}_{3}{ }^{\text {Mesa }}, o^{\prime}-\mathrm{CH}_{3}{ }^{\mathrm{Xyl}}\right), 2.09\left(\mathrm{~s}, 3 \mathrm{H}, o^{\prime}-\mathrm{CH}_{3}{ }^{\mathrm{Xyl}}\right), 1.96\left(\mathrm{~s}, 3 \mathrm{H}, p-\mathrm{CH}_{3}{ }^{\text {Mesb }}\right), 1.95\left(\mathrm{~s}, 3 \mathrm{H}, o^{\prime}-\mathrm{CH}_{3}{ }^{\text {Mesb }}\right), 1.12(\mathrm{~s}, 9 \mathrm{H}$, $\left.\mathrm{CH}_{3}^{\mathrm{t}-\mathrm{Bu}}\right)$.

${ }^{13} \mathrm{C}\left\{{ }^{1} \mathrm{H}\right\}$ NMR (151 MHz, benzene- $\left.d_{6}, 299 \mathrm{~K}\right)[$ selected resonances]: $\delta=189.1(\mathrm{br}, \mathrm{CH}=), 151.0(\mathrm{br}$, $\mathrm{PC}=), 146.6$ (br, i-Fmes), $145.4(i-\mathrm{Xyl}), 145.3\left(\mathrm{~d},{ }^{2} J_{\mathrm{PC}}=38.8 \mathrm{~Hz}, o-\mathrm{Mes}^{\mathrm{b}}\right), 144.2\left(\mathrm{~d},{ }^{2} J_{\mathrm{PC}}=5.0 \mathrm{~Hz}, o^{\prime}-\right.$ $\left.M^{2}{ }^{b}\right),\left[141.8\left(d,{ }^{2} J_{P C}=15.3 \mathrm{~Hz}\right), 141.6\left(\mathrm{~d},{ }^{2} J_{P C}=16.2 \mathrm{~Hz}\right)\right]\left(o-\mathrm{Mes}^{\mathrm{a}}, o^{\prime}-\mathrm{Mes}^{\mathrm{a}}\right), 138.8\left(\mathrm{~d},{ }^{4} J_{P C}=1.7 \mathrm{~Hz}\right.$, $p$-Mes $\left.{ }^{b}\right), 136.5\left(p-\right.$ Mes $\left.^{\mathrm{a}}\right), 136.2\left(\mathrm{~d},{ }^{1} \mathrm{~J}_{\mathrm{PC}}=28.7 \mathrm{~Hz}, i-\mathrm{Mes}^{\mathrm{a}}\right), 133.2$ (d, $\left.J=2.4 \mathrm{~Hz}, o-X y l\right), 132.9$ (d, $J=$ 
3.4 Hz, o'-Xyl), 130.4 (d, $\left.{ }^{1} J_{\mathrm{PC}}=6.1 \mathrm{~Hz}, i-\mathrm{Mes}^{\mathrm{b}}\right), 130.1\left(m-\mathrm{Mes}^{\mathrm{a}}\right), 130.0\left(\mathrm{~d},{ }^{3} J_{\mathrm{PC}}=7.0 \mathrm{~Hz}, m^{\prime}-\mathrm{Mes}^{\mathrm{a}}\right)$, $129.7(m-X y l), 129.5\left(m^{\prime}-M^{-} s^{b}\right), 129.4\left(m^{\prime}-X y l\right), 129.1$ (d, $\left.{ }^{3} J_{P C}=9.8 \mathrm{~Hz}, m-M^{2} s^{b}\right), 124.7$ (br, $m$-Fmes), 124.0 (br, $m^{\prime}$-Fmes), $91.5\left(\mathrm{~d},{ }^{2} \mathrm{JPC}_{\mathrm{PC}}=33.0 \mathrm{~Hz}, \mathrm{CH}^{\mathrm{t}-\mathrm{Bu}}\right), 38.0\left(\mathrm{C}^{\mathrm{t}-\mathrm{Bu}}\right), 28.2\left(\mathrm{br}, \mathrm{CH}_{3}^{\mathrm{t}-\mathrm{Bu}}\right), 25.0\left(o_{-}-\mathrm{CH}_{3}{ }^{\text {Mesa }}\right)$, $23.8\left(\mathrm{~d},{ }^{3} \mathrm{JPC}_{\mathrm{PC}}=2.8 \mathrm{~Hz}, \mathrm{o}^{\prime}-\mathrm{CH}_{3}{ }^{\mathrm{Mesb}}\right), 23.7\left(\mathrm{dq},{ }^{2} J_{\mathrm{PC}}=30.9 \mathrm{~Hz}, \mathrm{~J}_{\mathrm{FC}}=3.8 \mathrm{~Hz}, 0-\mathrm{CH}_{3}{ }^{\text {Mesb }}\right), 23.0$ (d, ${ }^{2} J_{\mathrm{PC}}=27.1$

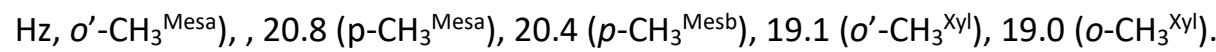

${ }^{11} \mathrm{~B}\left\{{ }^{1} \mathrm{H}\right\}$ NMR $\left(192 \mathrm{MHz}\right.$, benzene- $\left.d_{6}, 299 \mathrm{~K}\right): \delta=30.3\left(\mathrm{v}_{1 / 2} \approx 430 \mathrm{~Hz}\right)$.

${ }^{31} \mathrm{P}\left\{{ }^{1} \mathrm{H}\right\}$ NMR $\left(243 \mathrm{MHz}\right.$, benzene- $\left.d_{6}, 299 \mathrm{~K}\right): \delta=-17.7\left(\mathrm{q}, J_{\mathrm{FP}}=8.7 \mathrm{~Hz}\right)$.

${ }^{19} \mathrm{~F}$ NMR $\left(564 \mathrm{MHz}\right.$, benzene- $\left.d_{6}, 299 \mathrm{~K}\right): \delta=-55.4\left(\mathrm{~d}, J_{\mathrm{PF}}=7.9 \mathrm{~Hz}, 1 \mathrm{~F}, o-\mathrm{CF}_{3}{ }^{\mathrm{Fmes}}\right),-55.8\left(\mathrm{~s}, 1 \mathrm{~F}, o^{\prime}-\right.$ $\left.\mathrm{CF}_{3}{ }^{\mathrm{Fmes}}\right),-62.4\left(\mathrm{~s}, 1 \mathrm{~F}, p-\mathrm{CF}_{3}{ }^{\mathrm{Fmes}}\right)$.
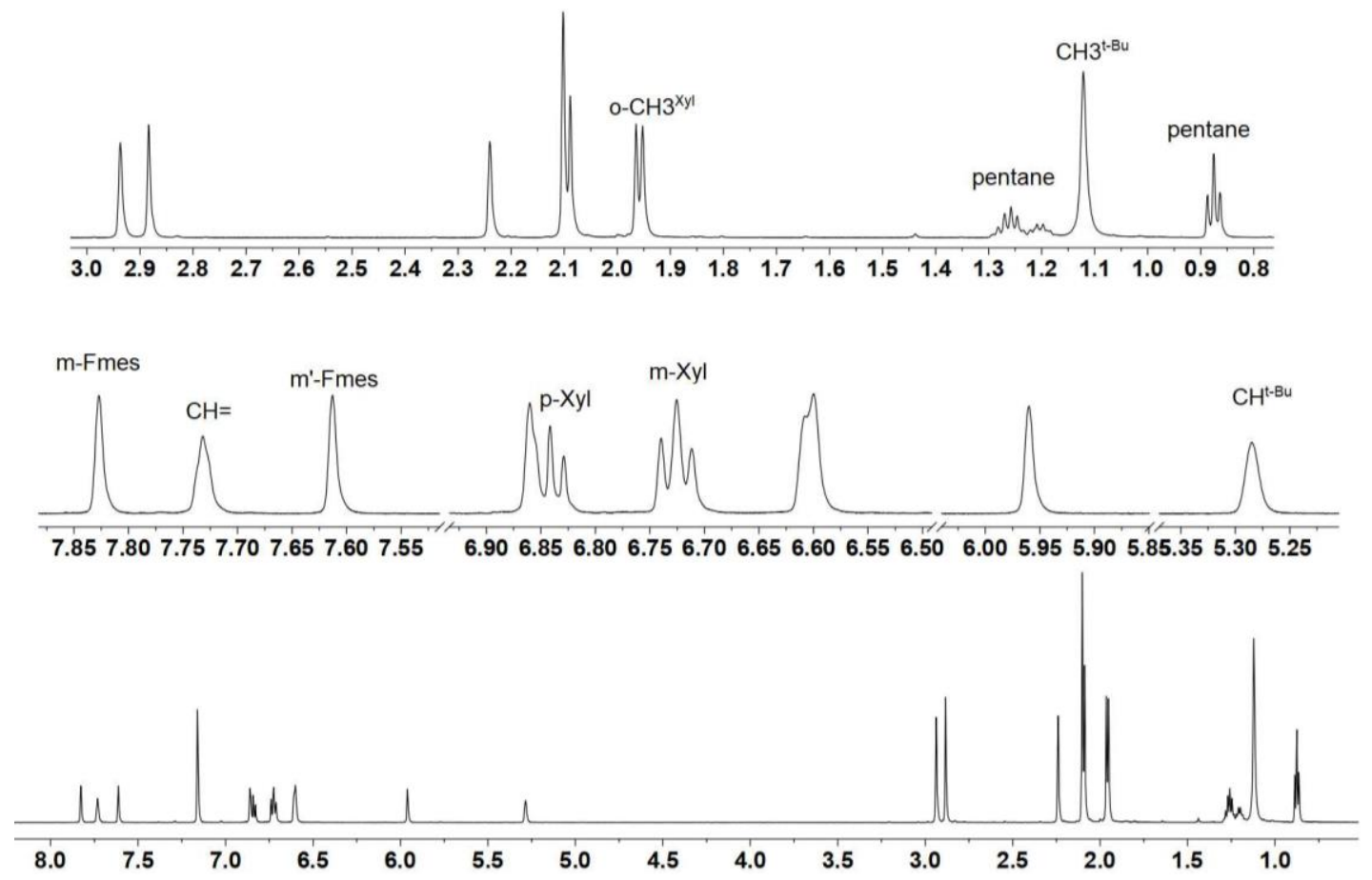

Figure S57. ${ }^{1} \mathrm{H}$ NMR (600 MHz, benzene- $d_{6}, 299 \mathrm{~K}$ ) spectrum of compound $15 \mathrm{~g}$.

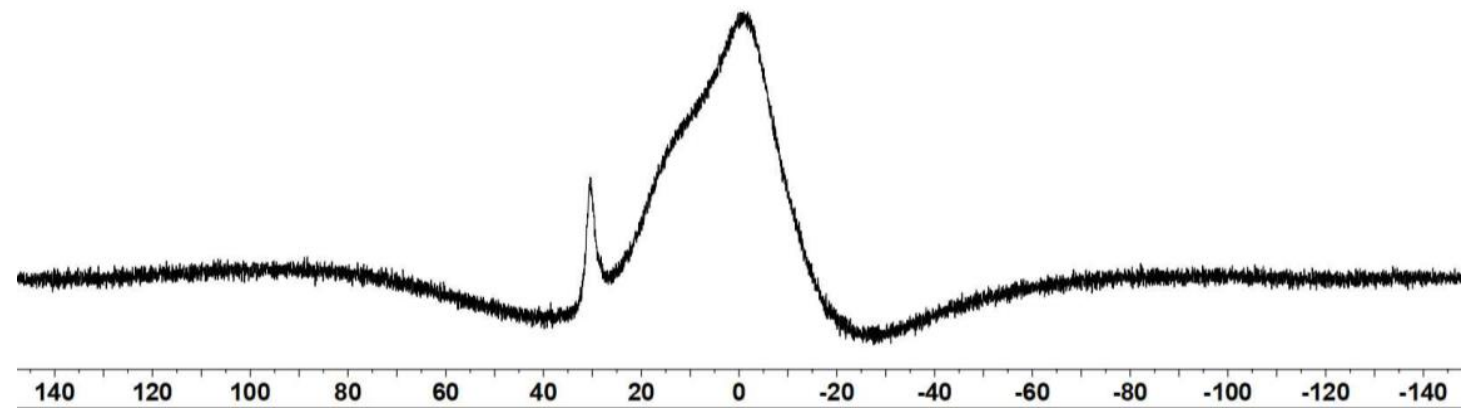

Figure S58. ${ }^{11} \mathrm{~B}\left\{{ }^{1} \mathrm{H}\right\}$ NMR (192 MHz, benzene- $\left.d_{6}, 299 \mathrm{~K}, 299 \mathrm{~K}\right)$ spectrum of compound 15g.

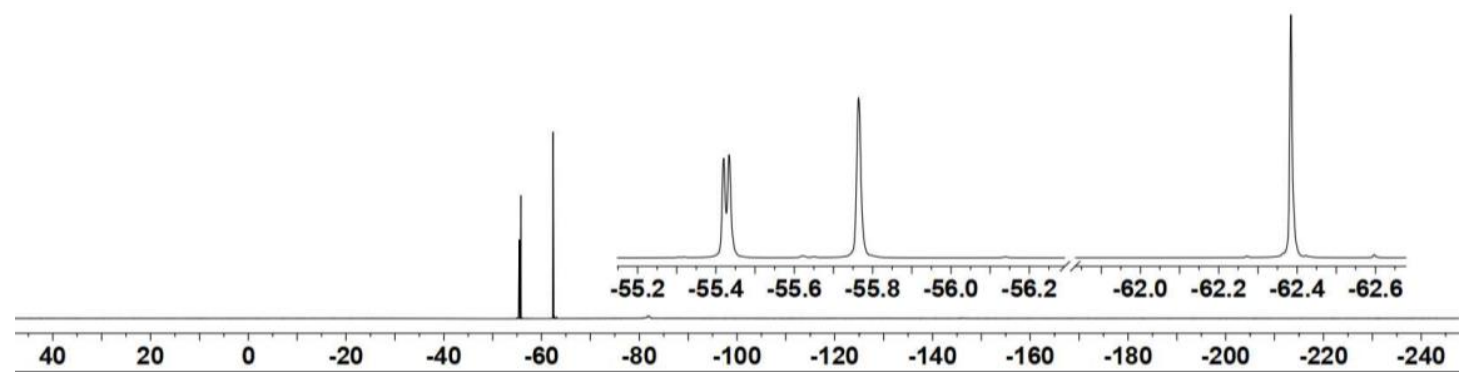

Figure S59. ${ }^{19} \mathrm{~F}$ NMR (564 MHz, benzene- $d_{6}, 299 \mathrm{~K}$ ) spectrum of compound $15 \mathrm{~g}$. 

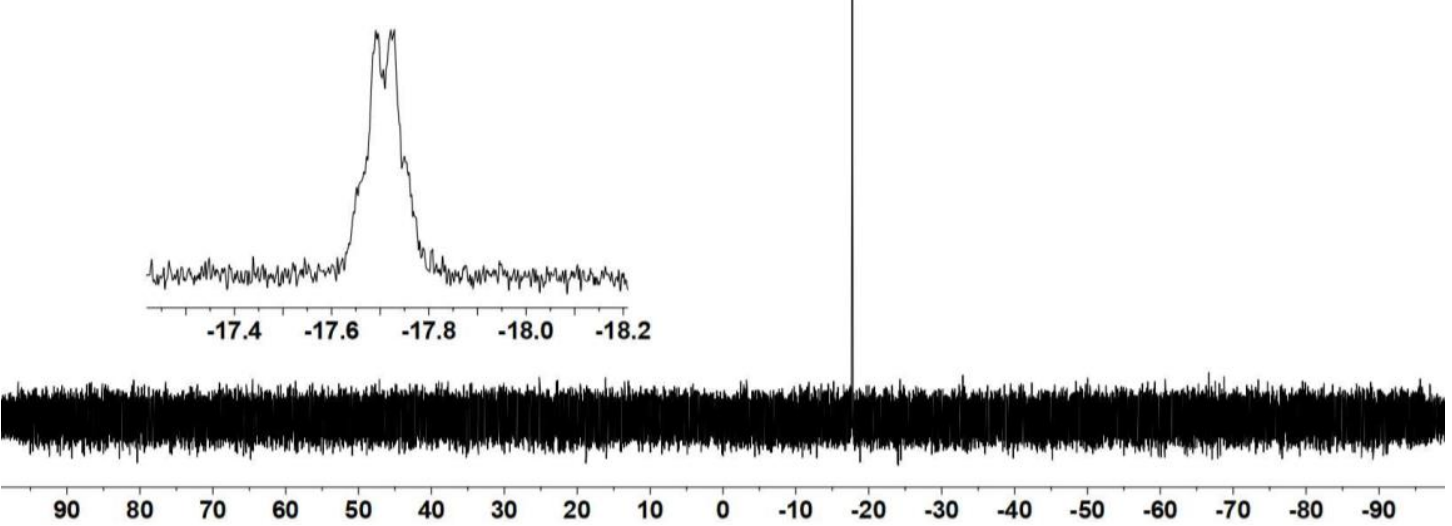

Figure S60. ${ }^{31} \mathrm{P}\left\{{ }^{1} \mathrm{H}\right\}$ NMR (192 MHz, benzene- $d_{6}, 299 \mathrm{~K}$ ) spectrum of compound $15 \mathrm{~g}$.
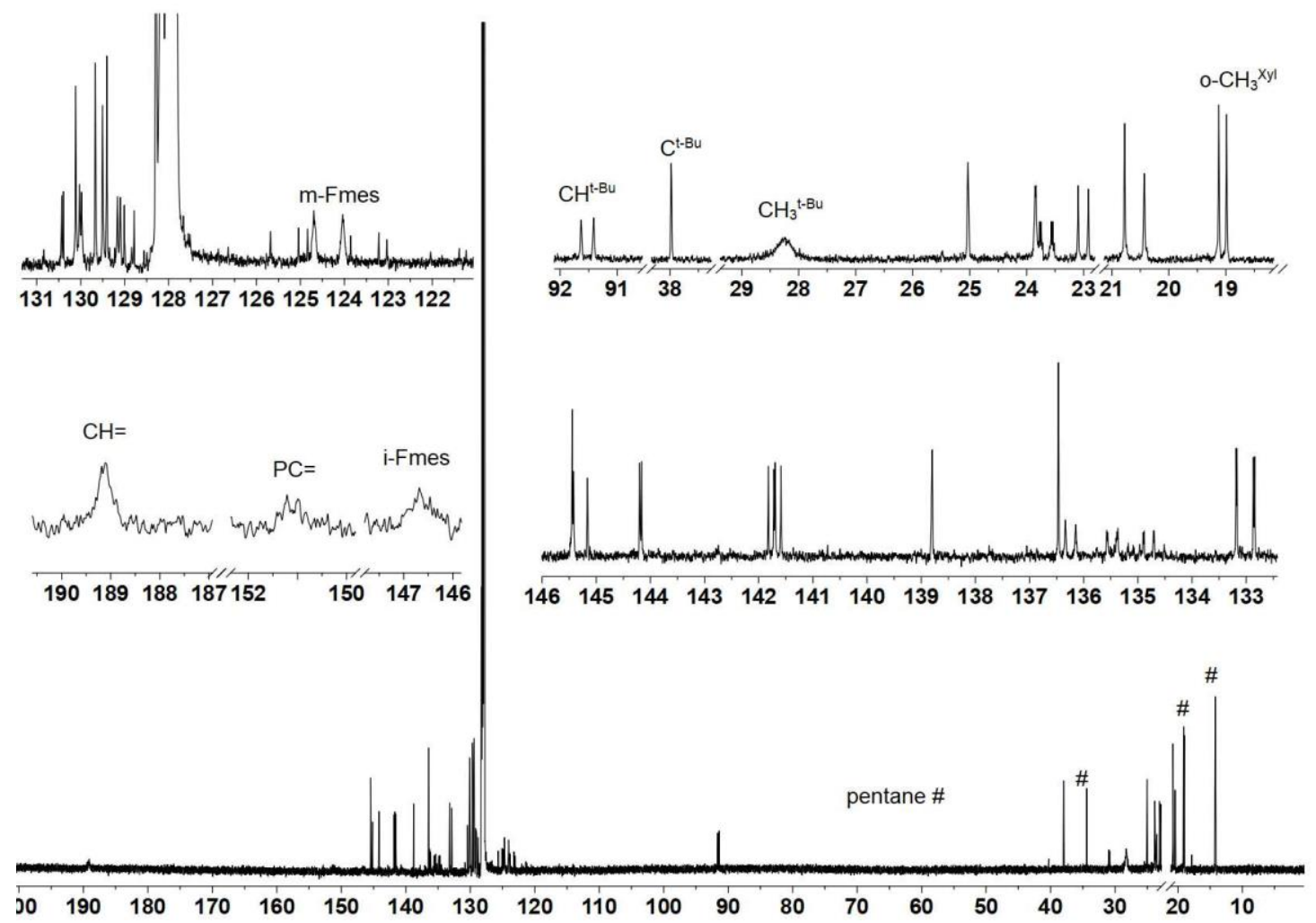

Figure S61. ${ }^{13} \mathrm{C}\left\{{ }^{1} \mathrm{H}\right\} \mathrm{NMR}\left(151 \mathrm{MHz}\right.$, benzene- $\left.d_{6}, 299 \mathrm{~K}\right)$ spectrum of compound $15 \mathrm{~g}$.

The formation of the FLP intermediate 13g was probed by NMR experiments (two days, $0.2 \mathrm{mmol}$ scale in $\left.\mathrm{C}_{6} \mathrm{D}_{6}(1 \mathrm{~mL})\right)$; the sample contains some starting material. 


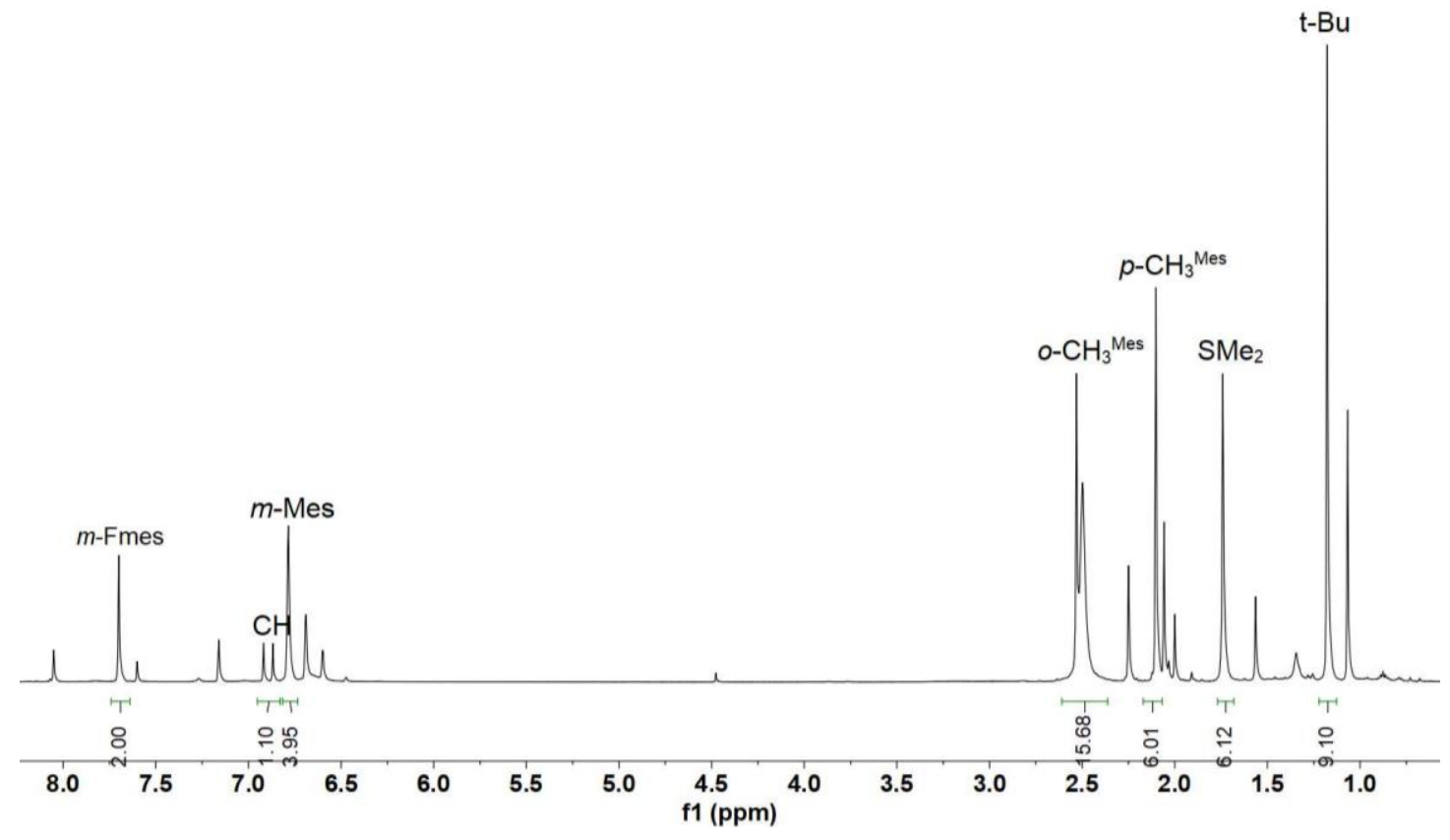

Figure S62. ${ }^{1} \mathrm{H}$ NMR (600 MHz, benzene- $\left.d_{6}, 299 \mathrm{~K}\right)$ spectrum of FLP intermediate $13 \mathrm{~g}$.

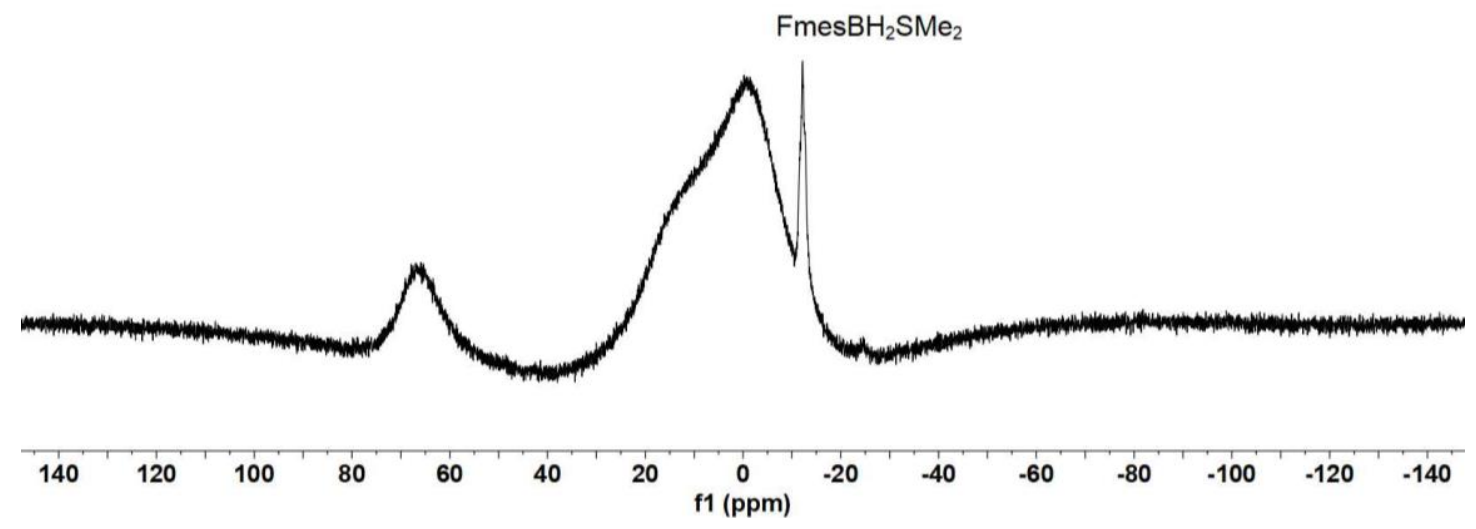

Figure S63. ${ }^{11} \mathrm{~B}$ NMR $\left(192 \mathrm{MHz}\right.$, benzene- $\left.d_{6}, 299 \mathrm{~K}, 299 \mathrm{~K}\right)$ spectrum of FLP intermediate 13g.

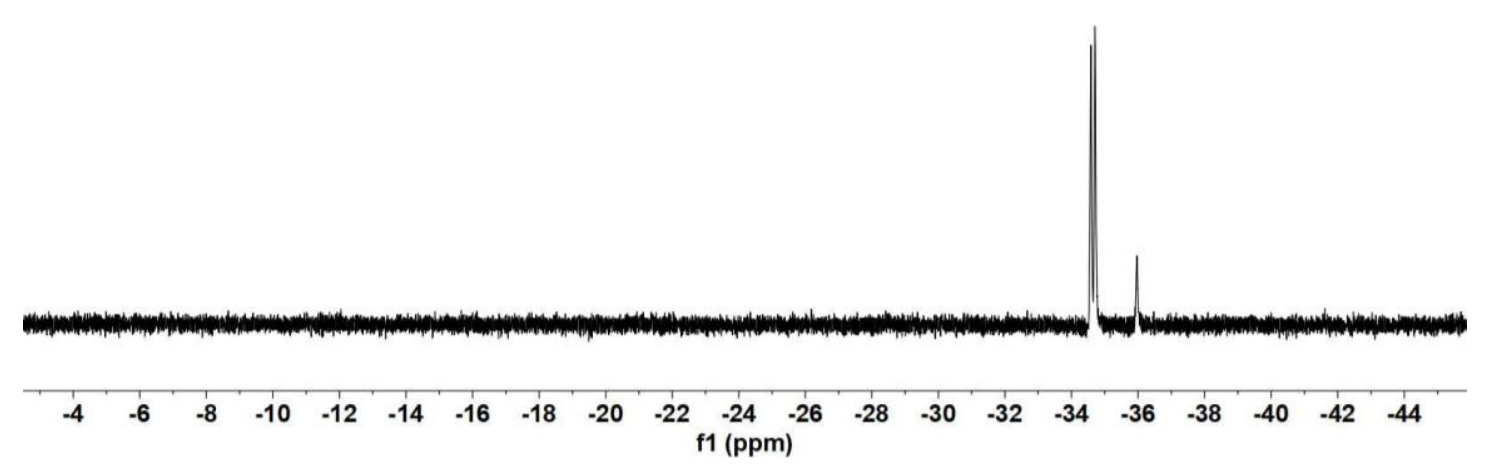

Figure S64. ${ }^{31} \mathrm{P}$ NMR $\left(192 \mathrm{MHz}\right.$, benzene- $\left.d_{6}, 299 \mathrm{~K}\right)$ spectrum of FLP intermediate $13 \mathrm{~g}$. 


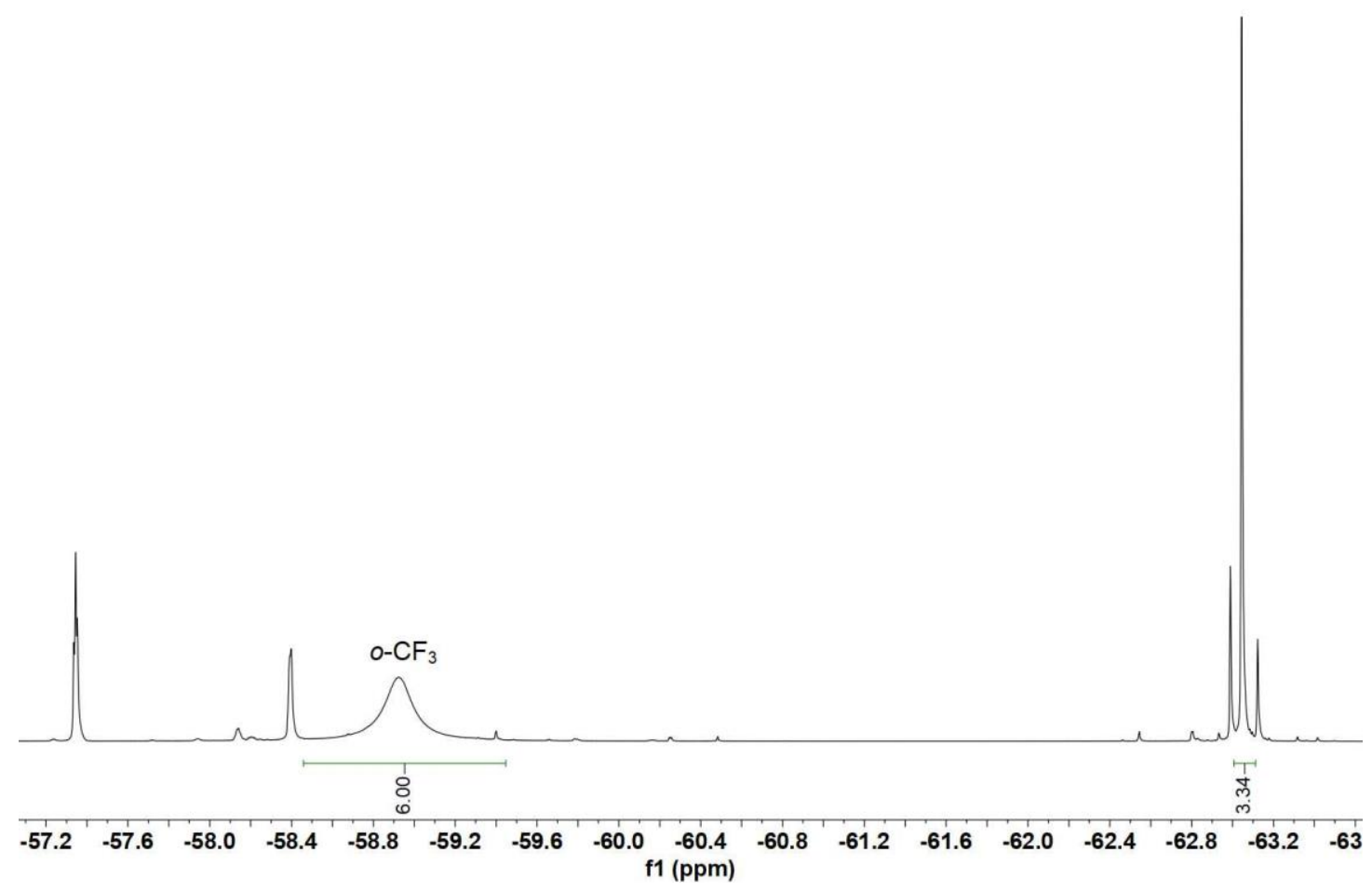

Figure S65. ${ }^{19} \mathrm{~F}$ NMR (564 MHz, benzene- $d_{6}, 299 \mathrm{~K}$ ) spectrum of FLP intermediate 13g.

Crystals suitable for X-ray crystal structure analysis were obtained from a solution of compound $15 \mathrm{~g}$ in pentane at $-35^{\circ} \mathrm{C}$.

X-ray crystal structure analysis of compound 15g (erk9300): A pale red prism-like specimen of $\mathrm{C}_{47} \mathrm{H}_{56} \mathrm{BF} 9 \mathrm{NP}$, approximate dimensions $0.180 \mathrm{~mm} \times 0.180 \mathrm{~mm} \times 0.240 \mathrm{~mm}$, was used for the $X$-ray crystallographic analysis. The X-ray intensity data were measured. A total of 1986 frames were collected. The total exposure time was 19.54 hours. The frames were integrated with the Bruker SAINT software package using a wide-frame algorithm. The integration of the data using a monoclinic unit cell yielded a total of 64524 reflections to a maximum $\theta$ angle of $66.90^{\circ}(0.84 \AA$ resolution), of which 7680 were independent (average redundancy 8.402, completeness $=99.6 \%$, $\left.\mathrm{R}_{\text {int }}=7.88 \%, \mathrm{R}_{\text {sig }}=4.27 \%\right)$ and $6002(78.15 \%)$ were greater than $2 \sigma\left(\mathrm{F}^{2}\right)$. The final cell constants of a $=12.9016(11) \AA, \underline{b}=12.5211(11) \AA ̊ . \underline{c}=27.465(2) \AA, \beta=102.563(5)^{\circ}$, volume $=4330.5(6) \AA^{3}$, are based upon the refinement of the XYZ-centroids of 9686 reflections above $20 \sigma(I)$ with $7.793^{\circ}<2 \theta$ $<131.2^{\circ}$. Data were corrected for absorption effects using the multi-scan method (SADABS). The ratio of minimum to maximum apparent transmission was 0.798 . The calculated minimum and maximum transmission coefficients (based on crystal size) are 0.7640 and 0.8150 . The structure was solved and refined using the Bruker SHELXTL Software Package, using the space group $P 2_{1} / c$, with $\mathrm{Z}=4$ for the formula unit, $\mathrm{C}_{47} \mathrm{H}_{56} \mathrm{BF} 9 \mathrm{NP}$. The final anisotropic full-matrix least-squares refinement on $\mathrm{F}^{2}$ with 817 variables converged at $\mathrm{R} 1=8.51 \%$, for the observed data and $\mathrm{WR} 2=$ $17.76 \%$ for all data. The goodness-of-fit was 1.123 . The largest peak in the final difference electron density synthesis was $0.363 \mathrm{e}^{-/} / \AA^{3}$ and the largest hole was $-0.311 \mathrm{e} / / \AA^{3}$ with an RMS deviation of $0.064 \mathrm{e}^{-} / \AA^{3}$. On the basis of the final model, the calculated density was $1.300 \mathrm{~g} / \mathrm{cm}^{3}$ and $F(000)$, $1784 \mathrm{e}^{-}$. CCDC number: 2007634. 


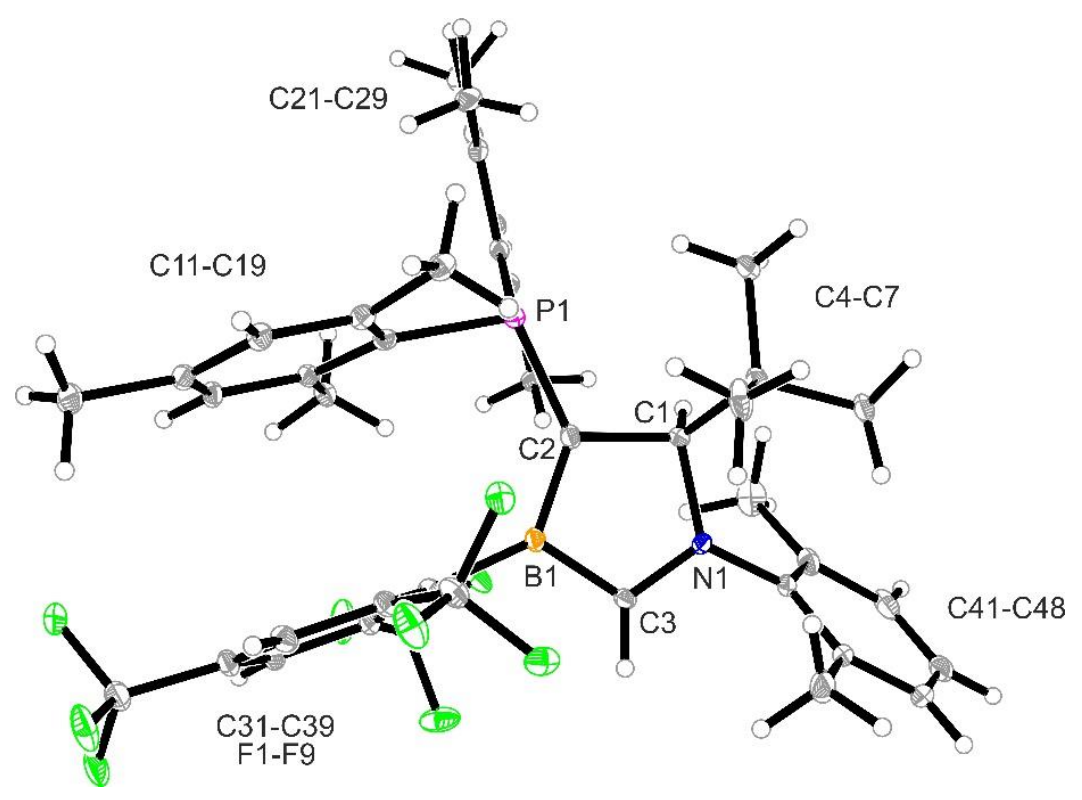

Figure S66. Crystal structure of compound $\mathbf{1 5 g}$ (thermal ellipsoids at 15\% probability).

\section{Preparation of the compound $16 \mathrm{~g}$}

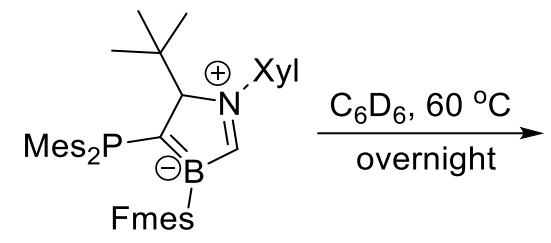

$15 \mathrm{~g}$<smiles>C[Pb]PC1=C(C(C)(C)C)N([Al])CN1P</smiles>

$16 \mathrm{~g}$

Scheme S12.

In a J. Young tube, compound $15 \mathrm{~g}(77.5 \mathrm{mg}, 1 \mathrm{mmol})$ in $\mathrm{C}_{6} \mathrm{D}_{6}(1 \mathrm{~mL})$ was heated at $60^{\circ} \mathrm{C}$ overnight to give a brown solution. NMR monitoring shows all starting material was transformed to the product. Volatiles were removed in vacuo. The residue was dissolved in heptane $(1 \mathrm{~mL})$ and stored at $-35^{\circ} \mathrm{C}$ to finally give the compound $16 \mathrm{~g}$ as a brown crystalline solid (52 $\mathrm{mg}, 67 \%$ yield).

Elemental Analysis for $\mathrm{C}_{42} \mathrm{H}_{44} \mathrm{BNF} 9 \mathrm{P}$ : calc. C (65.04 \%), H (5.72\%), N (1.81 \%); found: C (65.61 \%), $H(5.69 \%), N(1.87 \%)$.

HRMS for $\mathrm{C}_{42} \mathrm{H}_{45} \mathrm{BNF}_{9} \mathrm{P}^{+}[\mathrm{M}+\mathrm{H}]^{+}$: calc. 776.3241; found: 776.3249 .

${ }^{1} \mathrm{H}$ NMR $\left(600 \mathrm{MHz}\right.$, benzene- $\left.d_{6}, 299 \mathrm{~K}\right): \delta=7.74\left(\mathrm{~s}, 1 \mathrm{H}, m\right.$-Fmes), $7.38\left(\mathrm{~s}, 1 \mathrm{H}, m^{\prime}\right.$-Fmes), $6.89\left(\mathrm{t},{ }^{3} \mathrm{HH}_{\mathrm{H}}\right.$ $=7.5 \mathrm{~Hz}, 1 \mathrm{H}, p-\mathrm{Xyl}), 6.83\left(\mathrm{~s}, 1 \mathrm{H}, m-\mathrm{Mes}^{\mathrm{a}}\right), 6.79\left(\mathrm{~d},{ }^{3} \mathrm{~J}_{\mathrm{HH}}=7.8 \mathrm{~Hz}, 1 \mathrm{H}, m-\mathrm{Xyl}\right), 6.77\left(\mathrm{~d},{ }^{3} J_{\mathrm{HH}}=7.8 \mathrm{~Hz}\right.$, $\left.1 \mathrm{H}, m^{\prime}-\mathrm{Xyl}\right), 6.72\left(\mathrm{~d},{ }^{4} \mathrm{~J}_{\mathrm{PH}}=5.5 \mathrm{~Hz}, 1 \mathrm{H}, m-\mathrm{Mes}^{\mathrm{b}}\right), 6.58\left(\mathrm{~d},{ }^{4} J_{\mathrm{PH}}=4.0 \mathrm{~Hz}, 1 \mathrm{H}, m^{\prime}-\mathrm{Mes}^{\mathrm{a}}\right), 5.77\left(\mathrm{~d},{ }^{4} \mathrm{~J}_{\mathrm{PH}}=\right.$ $\left.1.9 \mathrm{~Hz}, 1 \mathrm{H}, m^{\prime}-\mathrm{Mes}^{\mathrm{b}}\right), 3.21\left(\mathrm{~s}, 2 \mathrm{H}, \mathrm{CH}_{2}\right), 2.93\left(\mathrm{~s}, 3 \mathrm{H}, o-\mathrm{CH}_{3}{ }^{\text {Mesa }}\right), 2.83\left(\mathrm{~d},{ }^{4} \mathrm{JHH}_{\mathrm{PH}}=2.5 \mathrm{~Hz}, 3 \mathrm{H}, o-\mathrm{CH}_{3}{ }^{\text {Mesb }}\right.$ ), $2.10\left(\mathrm{~s}, 3 \mathrm{H}, p-\mathrm{CH}_{3}{ }^{\text {Mesa }}\right), 2.084\left(\mathrm{~s}, 6 \mathrm{H}, o-\mathrm{CH}_{3}{ }^{\mathrm{Xyl}}, o^{\prime}-\mathrm{CH}_{3}{ }^{\text {Mesa }}\right), 2.076\left(\mathrm{~s}, 3 \mathrm{H}, o^{\prime}-\mathrm{CH}_{3}{ }^{\mathrm{Xy}}\right), 1.98(\mathrm{~s}, 3 \mathrm{H}, p-$ $\mathrm{CH}_{3}{ }^{\mathrm{Mesb}}$ ), 1.64 (s, 3H, $\left.o^{\prime}-\mathrm{CH}_{3}{ }^{\text {Mesb }}\right), 1.44\left(\mathrm{~d},{ }^{5} \mathrm{PHH}_{\mathrm{PH}}=1.3 \mathrm{~Hz}, 9 \mathrm{H}, \mathrm{CH}_{3}{ }^{\mathrm{t}-\mathrm{Bu}}\right)$.

${ }^{13} \mathrm{C}\left\{{ }^{1} \mathrm{H}\right\}$ NMR (151 MHz, benzene- $\left.d_{6}, 299 \mathrm{~K}\right)$ [selected resonances]: $\delta=193.9\left(\mathrm{~d},{ }^{2} \mathrm{JPC}_{\mathrm{PC}}=39.1 \mathrm{~Hz}, \mathrm{NC}=\right)$, 145.5 (i-Xyl), 144.5 (br, i-Fmes), 144.1 (d, $\left.{ }^{2} J_{\mathrm{PC}}=38.5 \mathrm{~Hz}, o-\mathrm{Mes}^{\mathrm{b}}\right), 142.8\left(\mathrm{~d},{ }^{2} J_{\mathrm{PC}}=4.4 \mathrm{~Hz}, o^{\prime}-\mathrm{Mes}^{\mathrm{b}}\right)$, $141.4\left(\mathrm{~d},{ }^{2} J_{\mathrm{PC}}=1.8 \mathrm{~Hz}, o-\mathrm{Mes}^{\mathrm{a}}\right), 140.6\left(\mathrm{~d},{ }^{2} \mathrm{~J}_{\mathrm{PC}}=34.0 \mathrm{~Hz}, o^{\prime}-\mathrm{Mes}^{\mathrm{a}}\right), 137.7\left(p-\mathrm{Mes}^{\mathrm{b}}\right), 137.0\left(\mathrm{~d},{ }^{1} \mathrm{~J}_{\mathrm{PC}}=\right.$ 
28.5 Hz, i-Mes $\left.{ }^{\mathrm{a}}\right), 135.43\left(p-\mathrm{Mes}^{\mathrm{a}}\right), 135.40(o-\mathrm{Xyl}), 135.0\left(o^{\prime}-\mathrm{Xyl}\right), 133.1$ (d, $\left.{ }^{1} \mathrm{~J}_{\mathrm{PC}}=7.8 \mathrm{~Hz}, i-\mathrm{Mes}^{\mathrm{b}}\right)$, $132.6(\mathrm{br}, \mathrm{BC}=), 130.8\left(m-\mathrm{Mes}^{\mathrm{a}}\right), 130.0\left(\mathrm{~d},{ }^{3} J_{\mathrm{PC}}=5.0 \mathrm{~Hz}, m^{\prime}-\mathrm{Mes}^{\mathrm{a}}\right), 129.8\left(\mathrm{~d},{ }^{3} J_{\mathrm{PC}}=9.2 \mathrm{~Hz}, m-\mathrm{Mes}^{\mathrm{b}}\right)$, $129.4\left(m^{\prime}-\right.$ Mes $\left.^{\mathrm{b}}\right), 128.8\left(m\right.$-Xyl), 128.5 ( $m^{\prime}$-Xyl), 127.7 (p-Xyl), 125.0 (br, $m$-Fmes), 124.6 (br, $m^{\prime}$ Fmes), $59.2\left(\mathrm{br}, \mathrm{CH}_{2}\right), 40.3\left(\mathrm{C}^{\mathrm{C}-\mathrm{Bu}}\right), 30.9\left(\mathrm{~d},{ }^{4} J_{\mathrm{PC}}=15.0 \mathrm{~Hz}, \mathrm{CH}_{3}^{\mathrm{t}-\mathrm{Bu}}\right), 25.5\left(o^{\prime}-\mathrm{CH}_{3}{ }^{\text {Mesb }}\right), 24.2\left(\mathrm{~d},{ }^{3} \int_{\mathrm{PC}}=\right.$ $\left.31.5 \mathrm{~Hz}, o-\mathrm{CH}_{3}{ }^{\text {Mesb }}\right), 22.8\left(\mathrm{~d},{ }^{3} J_{\mathrm{PC}}=2.8 \mathrm{~Hz}, o-\mathrm{CH}_{3}{ }^{\text {Mesa }}\right), 22.3$ (d, ${ }^{3} J_{\mathrm{PC}}=28.4 \mathrm{~Hz}, o^{\prime}-\mathrm{CH}_{3}{ }^{\text {Mesa }}$ ), 20.7 ( $p$ $\left.\mathrm{CH}_{3}{ }^{\text {Mesa }}\right), 20.4\left(p-\mathrm{CH}_{3}{ }^{\text {Mesb }}\right), 17.9$ (d, J = 2.1 Hz, o- $\left.\mathrm{CH}_{3}{ }^{\mathrm{Xyl}}, o^{\prime}-\mathrm{CH}_{3}{ }^{\mathrm{Xy}}\right)$.

${ }^{11} \mathrm{~B}\left\{{ }^{1} \mathrm{H}\right\}$ NMR $\left(192 \mathrm{MHz}\right.$, benzene- $\left.d_{6}, 299 \mathrm{~K}\right): \delta=59.3\left(\mathrm{v}_{1 / 2} \approx 1270 \mathrm{~Hz}\right)$.

${ }^{31} \mathrm{P}\left\{{ }^{1} \mathrm{H}\right\}$ NMR $\left(243 \mathrm{MHz}\right.$, benzene- $\left.d_{6}, 299 \mathrm{~K}\right): \delta=-35.0\left(\mathrm{v}_{1 / 2} \approx 6 \mathrm{~Hz}\right)$.

${ }^{19} \mathrm{~F}$ NMR $\left(564 \mathrm{MHz}\right.$, benzene- $\left.d_{6}\right): \delta=-55.0,-55.6$ (each s, each $\left.1 \mathrm{~F}, o-\mathrm{CF}_{3}{ }^{\mathrm{Fmes}}\right),-62.6\left(\mathrm{~s}, 1 \mathrm{~F}, p-\mathrm{CF}_{3}{ }^{\mathrm{Fmes}}\right.$ ).
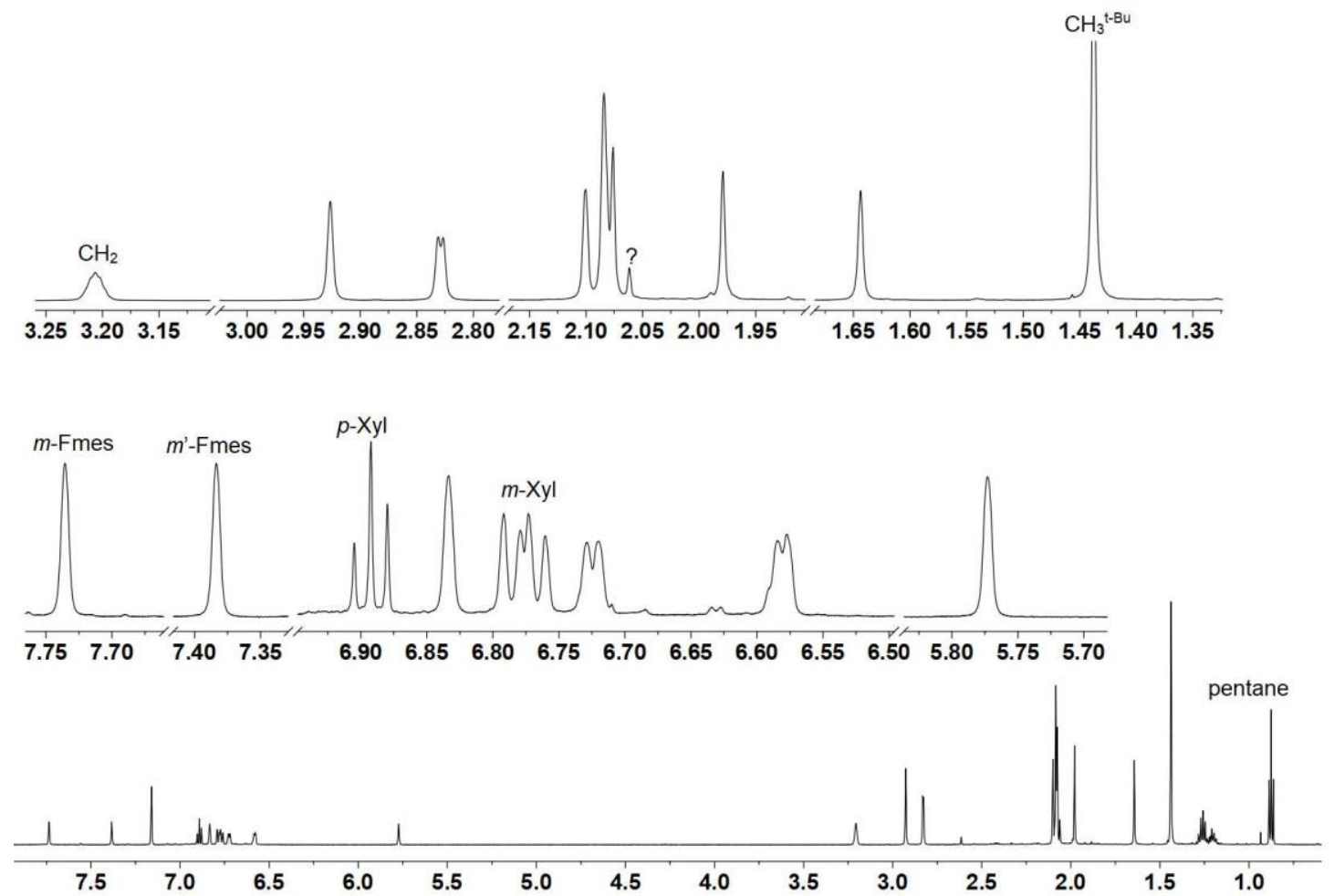

Figure S67. ${ }^{1} \mathrm{H}$ NMR (600 MHz, benzene- $\left.d_{6}, 299 \mathrm{~K}\right)$ spectrum of compound $16 \mathrm{~g}$.

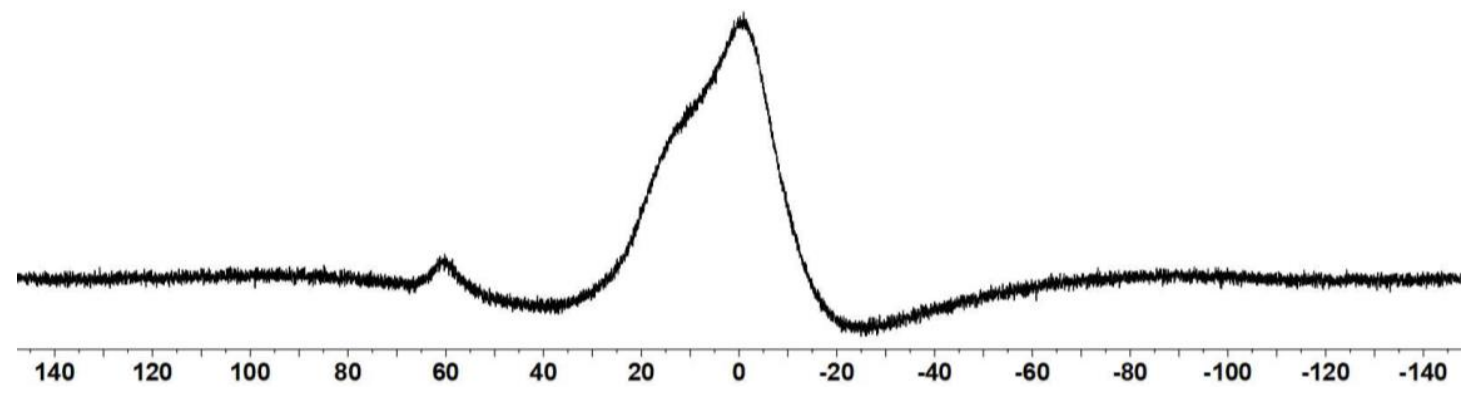

Figure S68. ${ }^{11} \mathrm{~B}\left\{{ }^{1} \mathrm{H}\right\}$ NMR $\left(192 \mathrm{MHz}\right.$, benzene- $\left.d_{6}, 299 \mathrm{~K}\right)$ spectrum of compound $16 \mathrm{~g}$. 


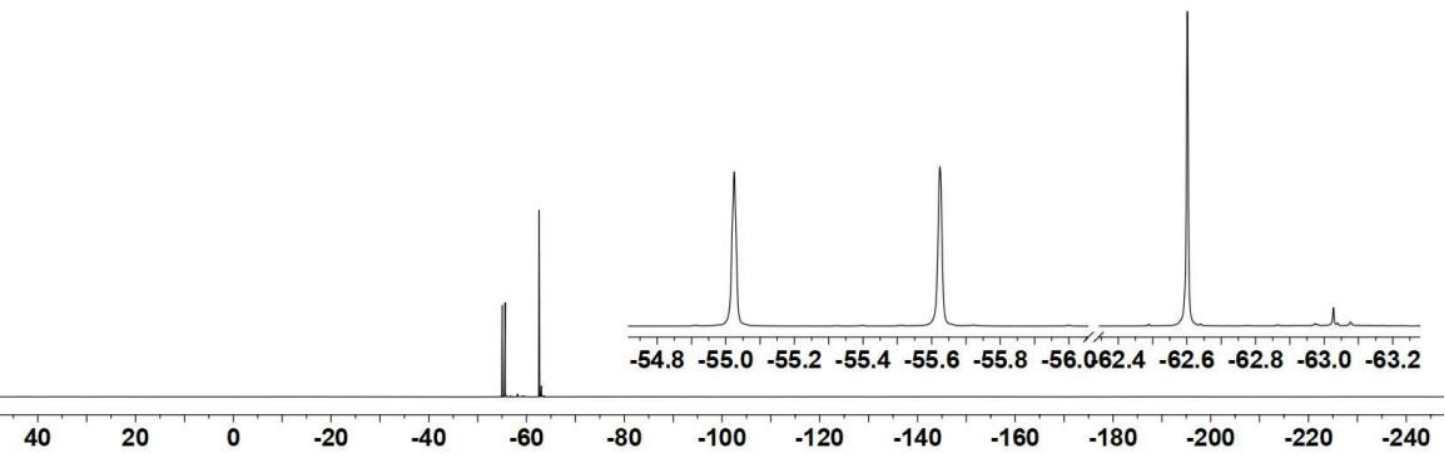

Figure S69. ${ }^{19} \mathrm{~F}$ NMR $\left(564 \mathrm{MHz}\right.$, benzene- $\left.d_{6}, 299 \mathrm{~K}\right)$ spectrum of compound $16 \mathrm{~g}$.

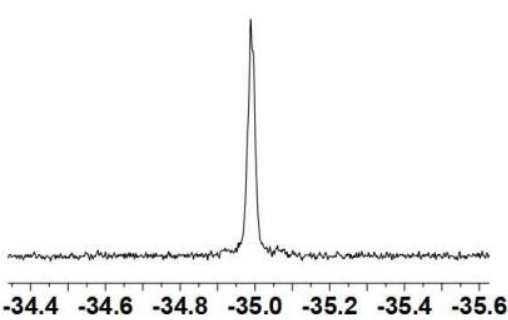

$\begin{array}{llllllllllllllllllll}90 & 80 & 70 & 60 & 50 & 40 & 30 & 20 & 10 & 0 & -10 & -20 & -30 & -40 & -50 & -60 & -70 & -80 & -90\end{array}$

Figure S70. ${ }^{31} \mathrm{P}\left\{{ }^{1} \mathrm{H}\right\} \mathrm{NMR}\left(192 \mathrm{MHz}\right.$, benzene- $\left.d_{6}, 299 \mathrm{~K}\right)$ spectrum of compound $16 \mathrm{~g}$.

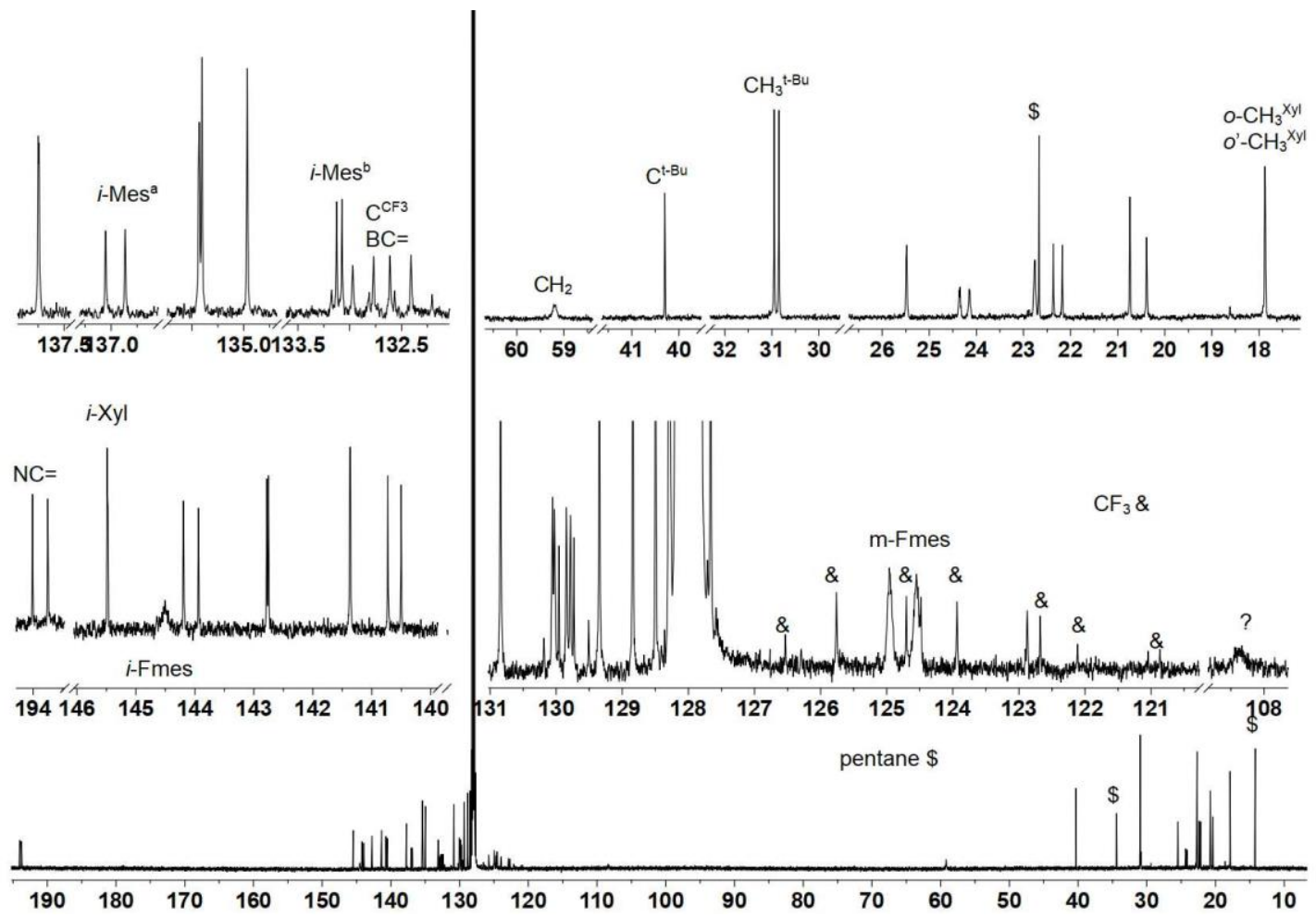

Figure S71. ${ }^{13} \mathrm{C}\left\{{ }^{1} \mathrm{H}\right\}$ NMR $\left(151 \mathrm{MHz}\right.$, benzene- $\left.d_{6}, 299 \mathrm{~K}\right)$ spectrum of compound $\mathbf{1 6 g}$. 
Crystals suitable for X-ray crystal structure analysis were obtained from a solution of $16 \mathrm{~g}$ in pentane at $-35^{\circ} \mathrm{C}$.

X-ray crystal structure analysis of compound 16g (erk9226): A red prism-like specimen of $\mathrm{C}_{47} \mathrm{H}_{56} \mathrm{BF} 9 \mathrm{NP}$, approximate dimensions $0.071 \mathrm{~mm} \times 0.160 \mathrm{~mm} \times 0.204 \mathrm{~mm}$, was used for the X-ray crystallographic analysis. The X-ray intensity data were measured. A total of 1862 frames were collected. The total exposure time was 22.24 hours. The frames were integrated with the Bruker SAINT software package using a narrow-frame algorithm. The integration of the data using a monoclinic unit cell yielded a total of 89324 reflections to a maximum $\theta$ angle of $26.73^{\circ}(0.79 \AA$ resolution), of which 9311 were independent (average redundancy 9.593, completeness $=99.9 \%$, $\left.R_{\text {int }}=6.00 \%, R_{\text {sig }}=3.52 \%\right)$ and $7230(77.65 \%)$ were greater than $2 \sigma\left(F^{2}\right)$. The final cell constants of a $=13.2994(6) \AA, \underline{b}=12.6152(6) \AA, \underline{c}=26.6795(11) \AA, \beta=101.2410(10)^{\circ}$, volume $=4390.3(3) \AA^{3}$, are based upon the refinement of the XYZ-centroids of 9883 reflections above $20 \sigma(I)$ with $4.491^{\circ}<2 \theta$ $<54.99^{\circ}$. Data were corrected for absorption effects using the multi-scan method (SADABS). The ratio of minimum to maximum apparent transmission was 0.947 . The calculated minimum and maximum transmission coefficients (based on crystal size) are 0.9730 and 0.9910 . The structure was solved and refined using the Bruker SHELXTL Software Package, using the space group $P 2_{1} / c$, with $\mathrm{Z}=4$ for the formula unit, $\mathrm{C}_{47} \mathrm{H}_{56} \mathrm{BF} 9 \mathrm{NP}$. The final anisotropic full-matrix least-squares refinement on $\mathrm{F}^{2}$ with 545 variables converged at $\mathrm{R} 1=5.36 \%$, for the observed data and $\mathrm{WR} 2=$ $12.61 \%$ for all data. The goodness-of-fit was 1.044 . The largest peak in the final difference electron density synthesis was $0.469 \mathrm{e}^{-} / \AA^{3}$ and the largest hole was $-0.392 \mathrm{e}^{-} / \AA^{3}$ with an RMS deviation of $0.057 \mathrm{e}^{-} / \AA^{3}$. On the basis of the final model, the calculated density was $1.283 \mathrm{~g} / \mathrm{cm}^{3}$ and $F(000)$, 1784 e. CCDC number: 2007640.

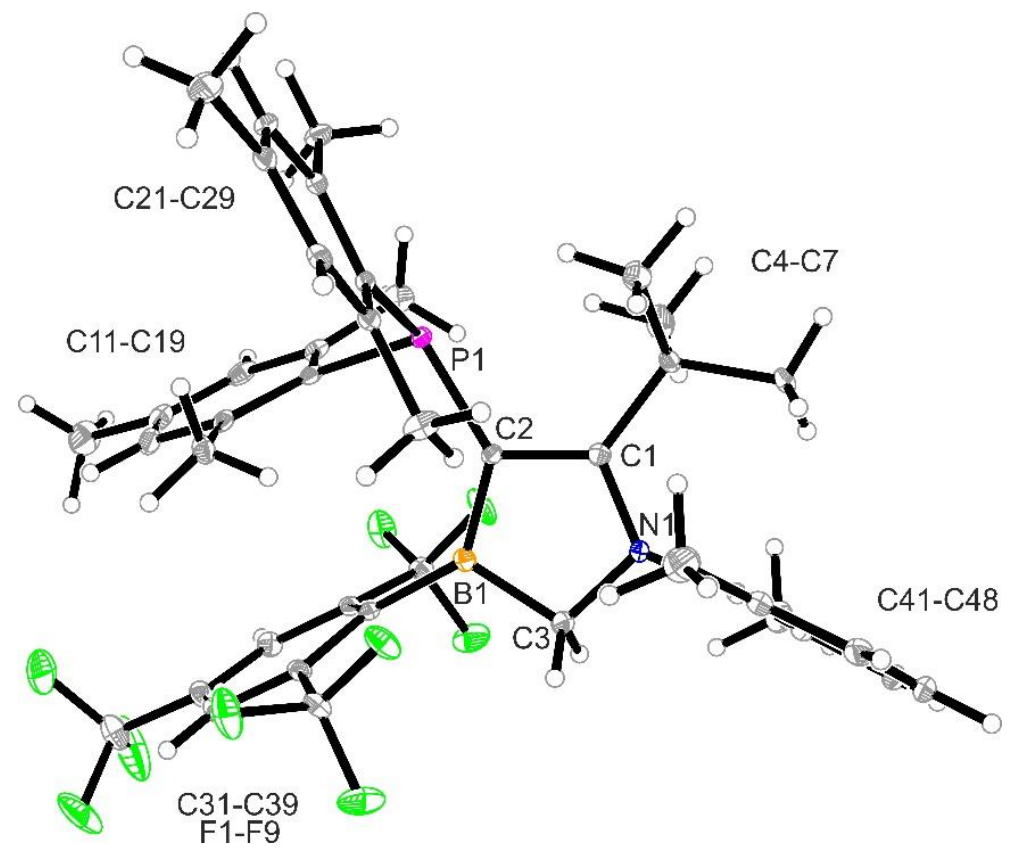

Figure S72. Crystal structure of compound $\mathbf{1 6 g}$ (thermal ellipsoids at 30\% probability). 


\section{Preparation of azaborolyl potassium 17 (in situ reaction)}

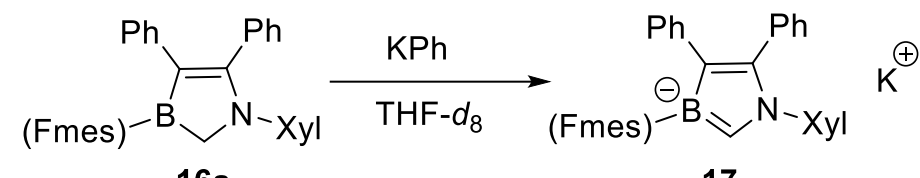

$16 a$

17

Scheme S13.

In a J. Young tube, $\mathrm{KPh}(23.2 \mathrm{mg}, 2 \mathrm{mmol}, 2$ equiv.) was added to a solution of azaborole $16 \mathrm{a}(60.3$ $\mathrm{mg}, 1 \mathrm{mmol}, 1$ equiv.) in THF- $d_{8}$ to give a deep brown solution. The resulting solution was stored at room temperature for $30 \mathrm{~min}$., then it was used for NMR experiments.

[Comments: The deprotonation of compound 16a works well with LiNMe $2, \mathrm{KTMP}$ and KPh, but when LiTMP was employed as a base, the process progressed slowly concomitant with decomposition. t-BuLi (6 equiv.) furnished the product however, decomposition was observed.]

${ }^{1}{ }_{H}$ NMR $\left(600 \mathrm{MHz}\right.$, THF- $\left.d_{8}, 299 \mathrm{~K}\right): \delta=7.95\left(\mathrm{~s}, 2 \mathrm{H}, m\right.$-Fmes), $6.84\left(\mathrm{~m}, 2 \mathrm{H}, o-\mathrm{Ph}^{\mathrm{N}}\right), 6.82(\mathrm{~m}, 1 \mathrm{H}, p-$ $\mathrm{Xyl}), 6.80\left(\mathrm{~m}, 2 \mathrm{H}, o-\mathrm{Ph}^{\mathrm{B}}\right), 6.79(\mathrm{~m}, 2 \mathrm{H}, m-\mathrm{Xyl}), 6.77\left(\mathrm{~m}, 2 \mathrm{H}, m-\mathrm{Ph}^{\mathrm{N}}\right), 6.74\left(\mathrm{~m}, 2 \mathrm{H}, m-\mathrm{Ph}^{\mathrm{B}}\right), 6.67(\mathrm{~m}$, $\left.1 \mathrm{H}, p-\mathrm{Ph}^{\mathrm{N}}\right), 6.57\left(\mathrm{~m}, 1 \mathrm{H}, p-\mathrm{Ph}^{\mathrm{B}}\right), 5.58(\mathrm{~s}, 1 \mathrm{H}, \mathrm{CH}), 2.06\left(\mathrm{~s}, 6 \mathrm{H}, o-\mathrm{CH}_{3}{ }^{\mathrm{Xxl}}\right)$.

${ }^{13} \mathrm{C}\left\{{ }^{1} \mathrm{H}\right\}$ NMR (151 MHz, THF-d $\left.d_{8}, 299 \mathrm{~K}\right): \delta=160.1$ (br, i-Fmes), $147.8\left(i-\mathrm{Ph}^{\mathrm{B}}\right), 146.8(i-\mathrm{Xyl}), 138.1(i-$ $\left.\mathrm{Ph}^{\mathrm{N}}\right), 137.0$ (o-Xyl), 133.3 (NC=), $130.4\left(o-\mathrm{Ph}^{\mathrm{N}}\right), 129.9\left(o-\mathrm{Ph}^{\mathrm{B}}\right), 127.8(m-\mathrm{Xyl}), 127.2\left(m-\mathrm{Ph}^{\mathrm{B}}\right), 126.9$ $\left(m-\mathrm{Ph}^{\mathrm{N}}\right), 126.3(\mathrm{br}, \mathrm{BC}=), 125.5(p-\mathrm{Xyl}), 124.2(\mathrm{br}, m-\mathrm{Fmes}), 123.0\left(p-\mathrm{Ph}^{\mathrm{N}}\right), 120.8\left(\mathrm{CH}, p-\mathrm{Ph}^{\mathrm{B}}\right), 18.3(o-$ $\left.\mathrm{CH}_{3}{ }^{\mathrm{XY}}\right)$.

${ }^{11} B\left\{{ }^{1} H\right\}$ NMR $\left(192 \mathrm{MHz}\right.$, THF- $\left.\left.d_{8}, 299 \mathrm{~K}\right)\right): \delta=23.2\left(\mathrm{v}_{1 / 2} \approx 380 \mathrm{~Hz}\right)$.

${ }^{19} \mathrm{~F}$ NMR $\left.\left(564 \mathrm{MHz}, \mathrm{THF}-d_{8}, 299 \mathrm{~K}\right)\right): \delta=-57.9\left(\mathrm{~s}, 2 \mathrm{~F}, o-\mathrm{CF}_{3}{ }^{\mathrm{Fmes}}\right),-63.2\left(\mathrm{~s}, 1 \mathrm{~F}, p-\mathrm{CF}_{3}{ }^{\mathrm{Fmes}}\right)$

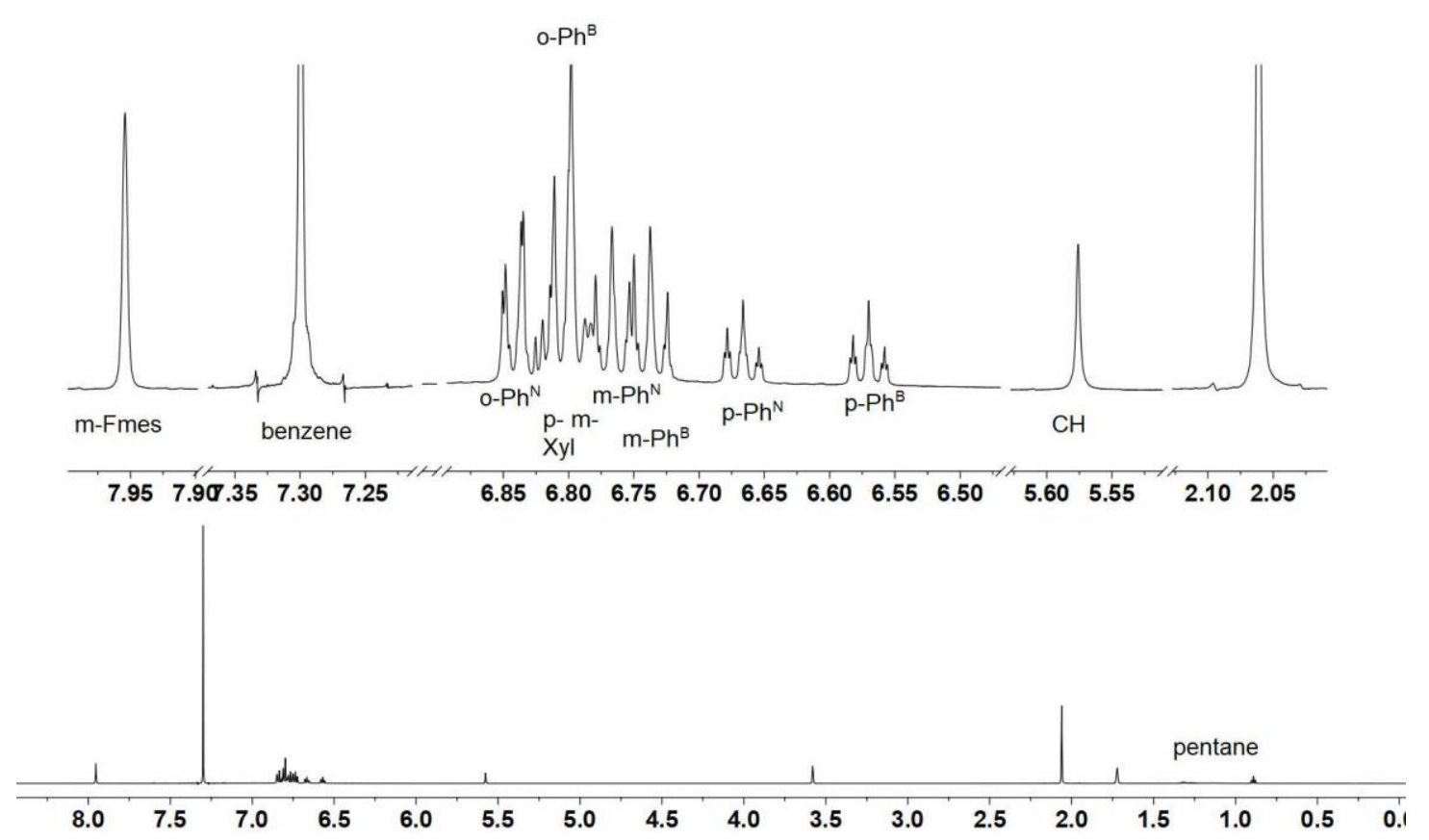

Figure S73. ${ }^{1} \mathrm{H}$ NMR $\left(600 \mathrm{MHz}, \mathrm{THF}-d_{8}, 299 \mathrm{~K}\right)$ spectrum of compound 17. 

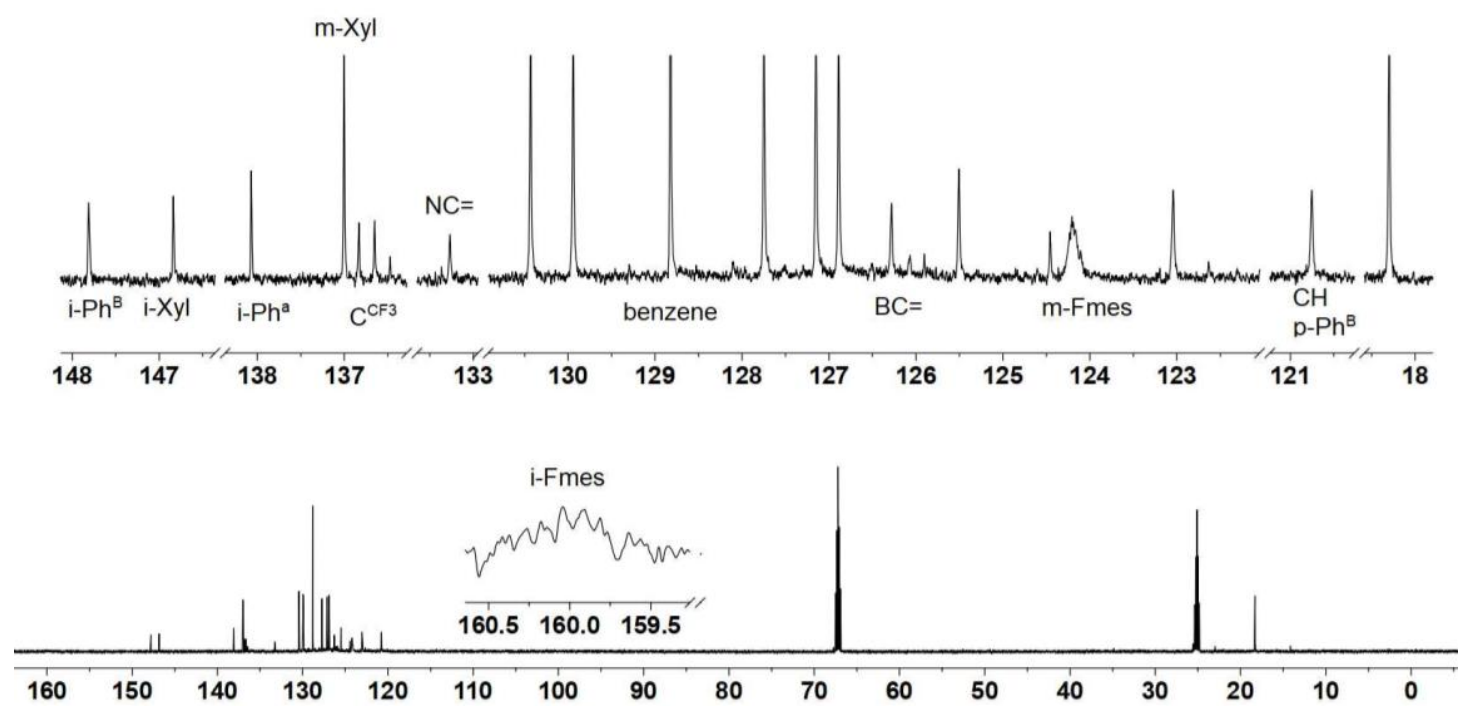

Figure S74. ${ }^{13} \mathrm{C}\left\{{ }^{1} \mathrm{H}\right\} \mathrm{NMR}\left(151 \mathrm{MHz}\right.$, benzene- $\left.d_{6}, 299 \mathrm{~K}\right)$ spectrum of compound 17.

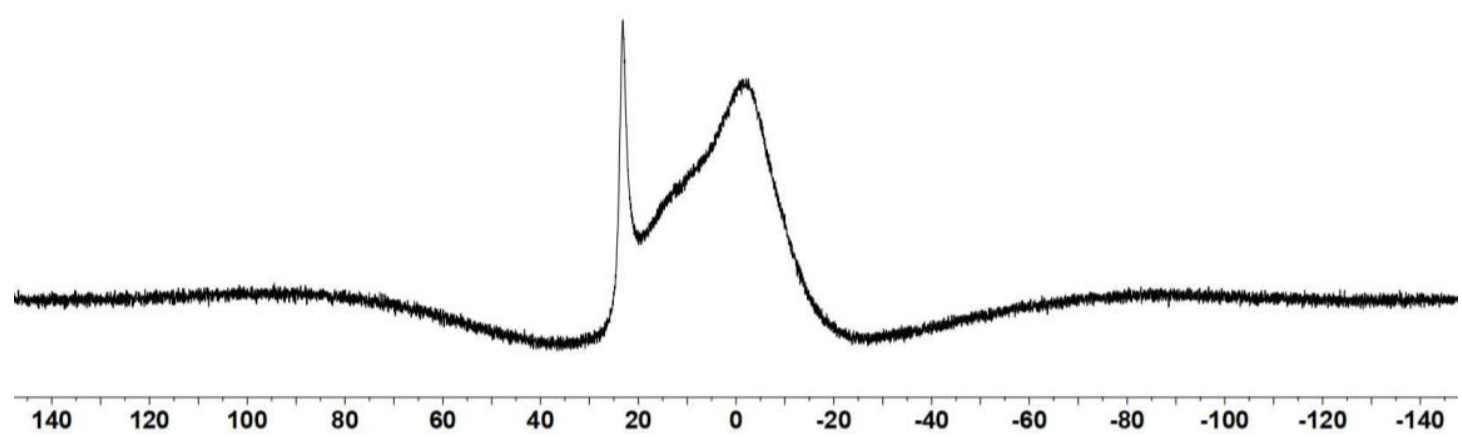

Figure S75. ${ }^{11} \mathrm{~B}\left\{{ }^{1} \mathrm{H}\right\} \mathrm{NMR}\left(192 \mathrm{MHz}, \mathrm{THF}-d_{8}, 299 \mathrm{~K}\right)$ spectrum of compound 17.

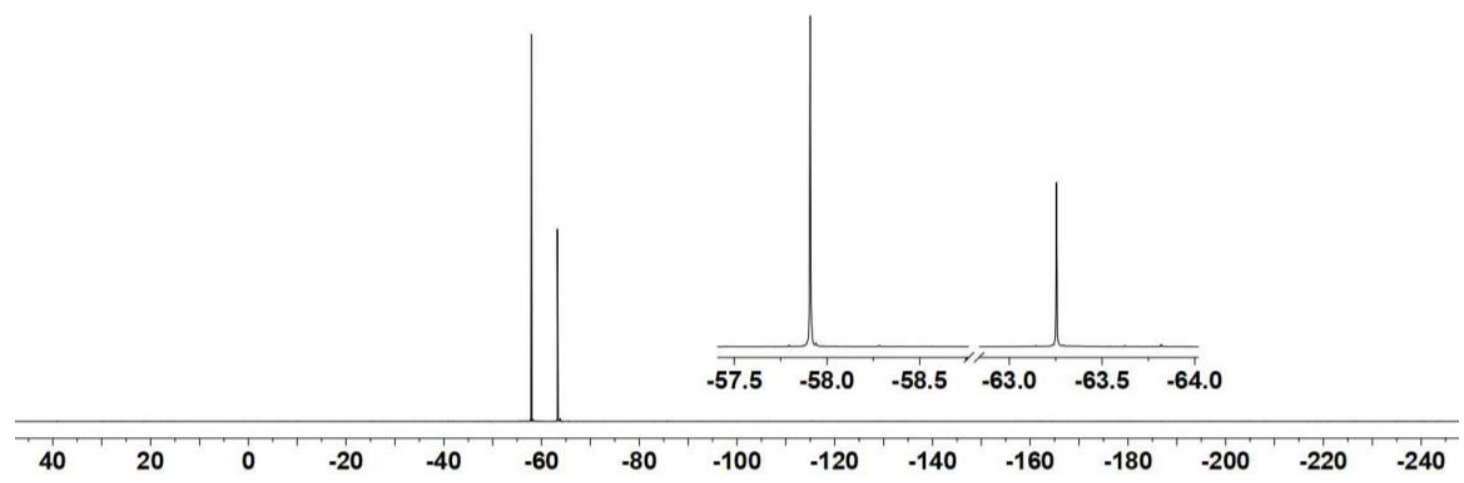

Figure S76. ${ }^{19} \mathrm{~F}$ NMR $\left(564 \mathrm{MHz}\right.$, THF- $d_{8}, 299 \mathrm{~K}$ ) spectrum of compound 17. 


\section{Preparation of compound 18a}

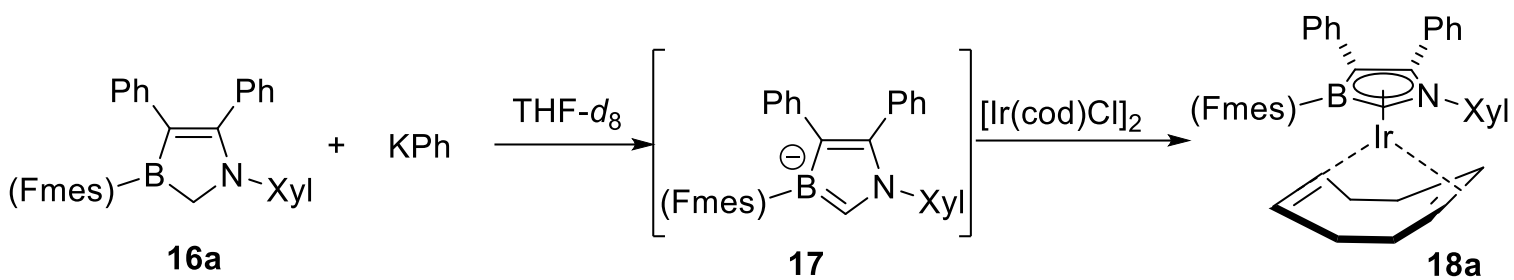

\section{Scheme S14.}

In a J. Young tube, KPh ( $23.2 \mathrm{mg}, 2 \mathrm{mmol}, 2$ equiv.) was added to a solution of azaborole $16 \mathrm{a}(60.3$ $\mathrm{mg}, 1 \mathrm{mmol}, 1$ equiv.) in THF- $d_{8}$ to give a deep brown solution at room temperature. The resulting solution was stored at room temperature for $30 \mathrm{~min}$. Then $[\mathrm{Ir}(\operatorname{cod}) \mathrm{Cl}]_{2}(33.6 \mathrm{mg}, 0.5 \mathrm{mmol}, 1$ equiv.) was added and the resulting mixture was stored for overnight. All the volatiles were removed in vacuo. The residue was dispersed in pentane $(20 \mathrm{~mL})$ and the solid was filtered off. The solution was concentrated to ca. $1 \mathrm{~mL}$ and stored in $-35^{\circ} \mathrm{C}$ to finally give the compound 18a as light-yellow crystalline solid ( $33 \mathrm{mg}, 36 \%$ yield).

[Comments: As we show in the formation of compound 17, the deprotonation works well with $\mathrm{LiNMe}_{2}$ or KTMP. However, when the metal salt was added, compound 16a was observed as the major component.]

Elemental Analysis for $\mathrm{C}_{41} \mathrm{H}_{36} \mathrm{BNF}_{9} \mathrm{IrCl} 2\left[\mathrm{M}+\mathrm{CH}_{2} \mathrm{Cl}_{2}\right]$ : calc. $\mathrm{C}(49.86 \%), \mathrm{H}(3.67 \%), \mathrm{N}(1.42 \%)$; found: C (50.12 \%), H (3.58 \%), N (1.20\%).

${ }^{1} \mathrm{H}$ NMR (600 MHz, methylene chloride- $\left.d_{2}, 268 \mathrm{~K}\right): \delta=8.21$ (s, $1 \mathrm{H}, m$-Fmes), 8.04 (s, $1 \mathrm{H}, m^{\prime}$-Fmes), $7.13(\mathrm{~m}, 1 \mathrm{H}, m-\mathrm{Xyl}), 7.08\left(\mathrm{~m}, 6 \mathrm{H}, o-\mathrm{Ph}^{\mathrm{N}}, p-\mathrm{Ph}^{\mathrm{N}}, m-\mathrm{Ph}^{\mathrm{B}}, p-\mathrm{Ph}^{\mathrm{B}}\right), 7.04(\mathrm{~m}, 1 \mathrm{H}, p-\mathrm{Xyl}), 6.98(\mathrm{~m}, 2 \mathrm{H}, m-$ $\left.\mathrm{Ph}^{\mathrm{N}}\right), 6.87\left(\mathrm{~m}, 2 \mathrm{H}, o-\mathrm{Ph}^{\mathrm{B}}\right), 6.72\left(\mathrm{~d}, 3^{3} \mathrm{HH}=7.6,1 \mathrm{H}, \mathrm{m}^{\prime}-\mathrm{Xyl}\right), 4.71(\mathrm{~s}, 1 \mathrm{H}, \mathrm{CH}),[4.19,4.03,3.87$, 3.73] (each $\mathrm{m}$, each $\left.1 \mathrm{H}, \mathrm{CH}={ }^{\mathrm{cod}}\right), 3.20\left(\mathrm{~s}, 3 \mathrm{H}, \mathrm{o}_{-}-\mathrm{CH}_{3}{ }^{\mathrm{Xy}}\right),[2.33(\mathrm{~m}, 2 \mathrm{H}), 2.04(\mathrm{~m}, 2 \mathrm{H}), 1.84(\mathrm{~m}, 2 \mathrm{H}), 1.69$ $(\mathrm{m}, 1 \mathrm{H}), 1.52(\mathrm{~m}, 1 \mathrm{H})]\left(\mathrm{CH}_{2}{ }^{\mathrm{cod}}\right), 1.77\left(\mathrm{~s}, 3 \mathrm{H}, \mathrm{o}^{\prime}-\mathrm{CH}_{3}{ }^{\mathrm{Xy}}\right)$.

${ }^{13} \mathrm{C}\left\{{ }^{1} \mathrm{H}\right\}$ NMR (151 MHz, methylene chloride- $d_{2}, 268 \mathrm{~K}$ ) [selected resonances]: $\delta=141.9$ (br, $\left.i-\mathrm{Fmes}\right)$, $139.2\left(i-\mathrm{Ph}^{\mathrm{B}}\right) 136.9\left(o^{\prime}-\mathrm{Xyl}\right), 134.5$ (p-Xyl), $133.7(o-\mathrm{Xyl}), 132.0\left(o-\mathrm{Ph}^{\mathrm{N}}\right), 129.9\left(i-\mathrm{Ph}^{\mathrm{N}}\right), 129.4\left(o-\mathrm{Ph}^{\mathrm{B}}\right)$, $129.0(m-\mathrm{Xyl}), 128.9\left(m^{\prime}-\mathrm{Xyl}\right), 128.6\left(p-\mathrm{Ph}^{\mathrm{N}}\right), 128.2(p-\mathrm{Xyl}), 127.8\left(m-\mathrm{Ph}^{\mathrm{B}}, m^{\prime}-\mathrm{Fmes}\right), 127.1\left(m-\mathrm{Ph}^{\mathrm{N}}\right)$, 126.2 (br, m-Fmes), $125.4\left(p-\mathrm{Ph}^{\mathrm{B}}\right), 115.9$ (NC=), 112.0 (br, BC=), 90.3 (br, $\left.\mathrm{CH}\right),[69.1,65.4$, 55.4, 53.6] $\left(\mathrm{CH}={ }^{\mathrm{cod}}\right),[34.0,33.6,32.1,30.2]\left(\mathrm{CH}_{2}{ }^{\mathrm{cod}}\right), 19.4\left(0-\mathrm{CH}_{3}{ }^{\mathrm{Xyl}}\right), 18.4\left(o^{\prime}-\mathrm{CH}_{3}{ }^{\mathrm{Xy}}\right)$.

${ }^{11}$ B NMR (192 MHz, methylene chloride- $\left.d_{2}, 299 \mathrm{~K}\right): \delta=16.5\left(\mathrm{v}_{1 / 2} \approx 350 \mathrm{~Hz}\right)$.

${ }^{19} \mathrm{~F}$ NMR $\left(564 \mathrm{MHz}\right.$, methylene chloride- $\left.d_{2}, 299 \mathrm{~K}\right): \delta=[-52.7,-52.8]\left(\right.$ each $\mathrm{s}$, each $\left.1 \mathrm{~F}, o-\mathrm{CF}_{3}\right),-63.4$ $\left(s, 1 \mathrm{~F}, p-\mathrm{CF}_{3}\right)$. 


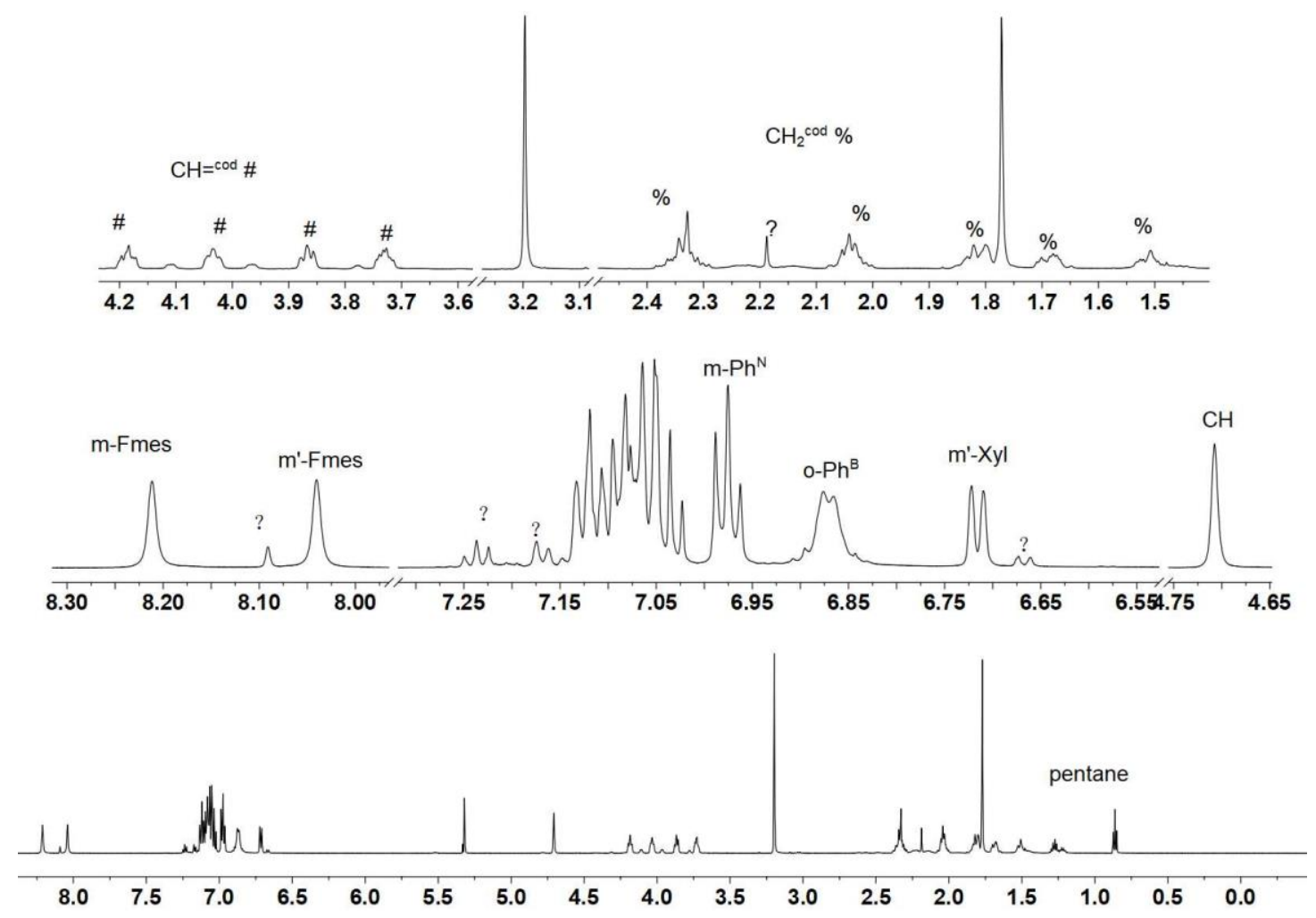

Figure 77. ${ }^{1} \mathrm{H}$ NMR (600 MHz, methylene chloride- $d_{2}, 268 \mathrm{~K}$ ) spectrum of compound 18a.

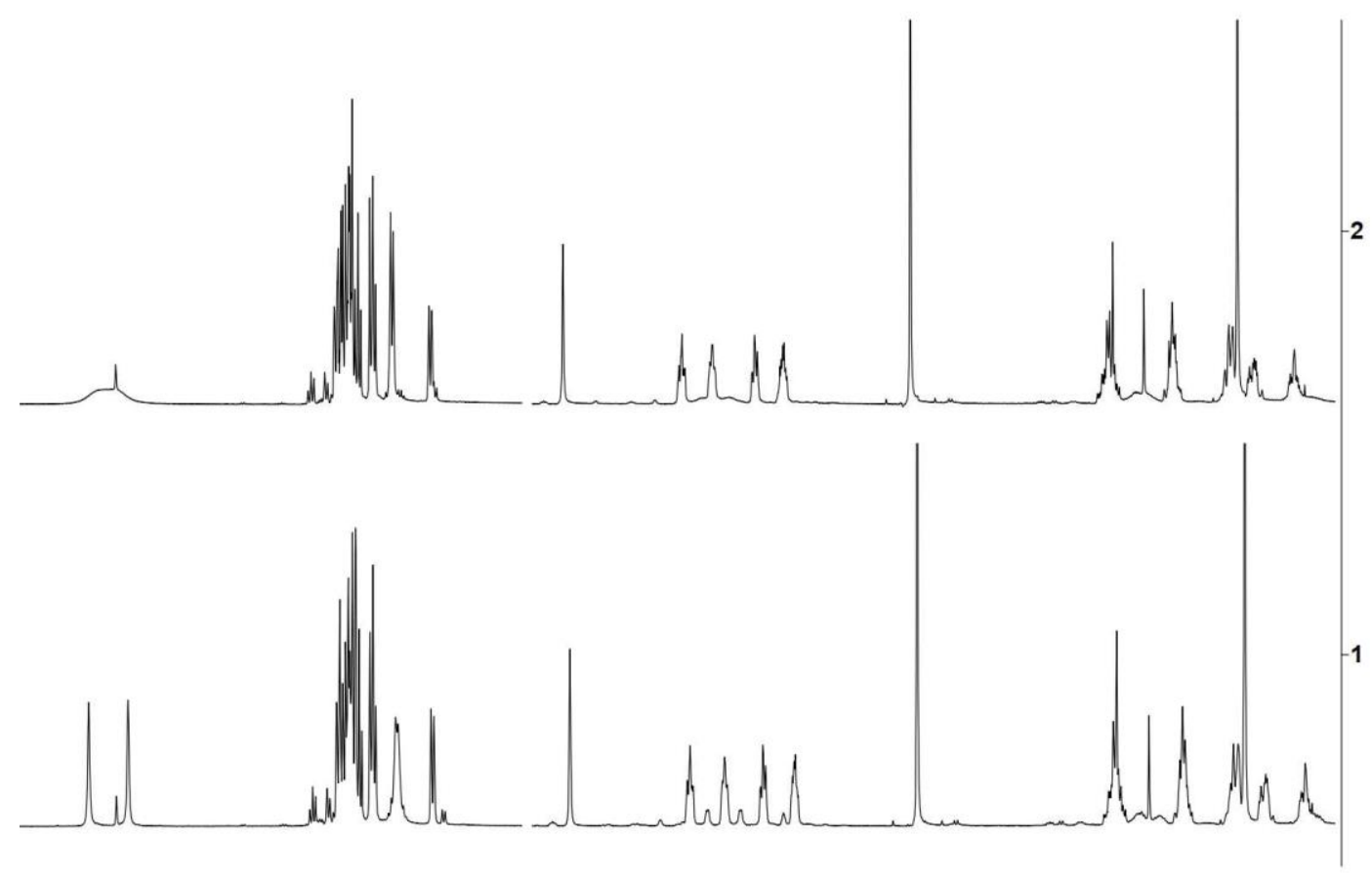

$\begin{array}{llllllllllllllllllllllllllllllllllllll}8.4 & 8.2 & 8.0 & 7.8 & 7.6 & 7.4 & 7.2 & 7.0 & 6.8 & 6.6 & 6.4 & 4.8 & 4.6 & 4.4 & 4.2 & 4.0 & 3.8 & 3.6 & 3.4 & 3.2 & 3.0 & 2.8 & 2.6 & 2.4 & 2.2 & 2.0 & 1.8 & 1.6 & 1.4\end{array}$

Figure 78. ${ }^{1} \mathrm{H}$ NMR (600 MHz, methylene chloride- $d_{2}$ ) spectra of compound $18 \mathrm{a}(1)$ at $268 \mathrm{~K},(2)$ at $299 \mathrm{~K}$. 

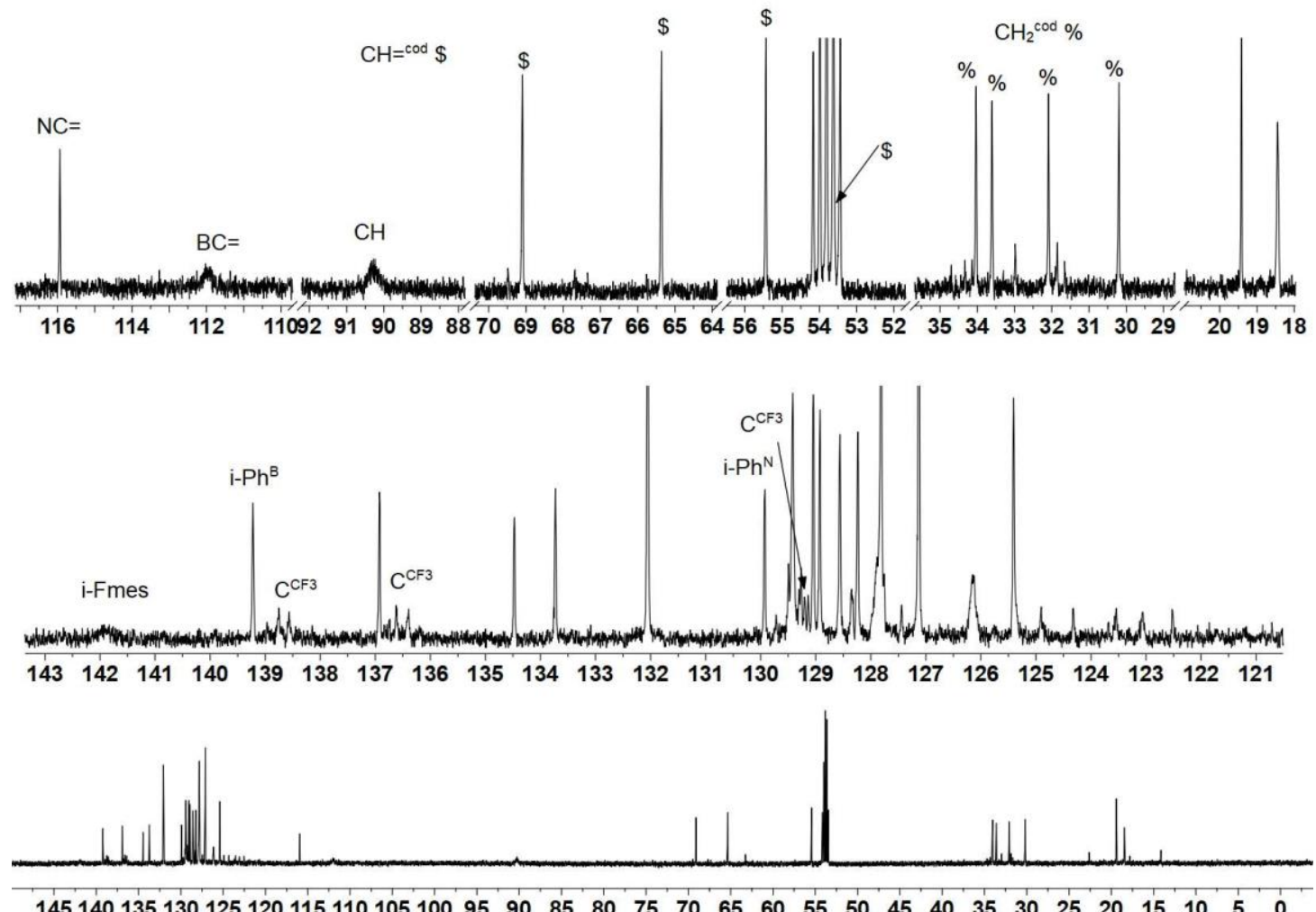

Figure 79. ${ }^{13} \mathrm{C}\left\{{ }^{1} \mathrm{H}\right\} \mathrm{NMR}\left(151 \mathrm{MHz}\right.$, methylene chloride- $\left.d_{2}, 268 \mathrm{~K}\right)$ spectrum of compound $18 \mathrm{a}$.

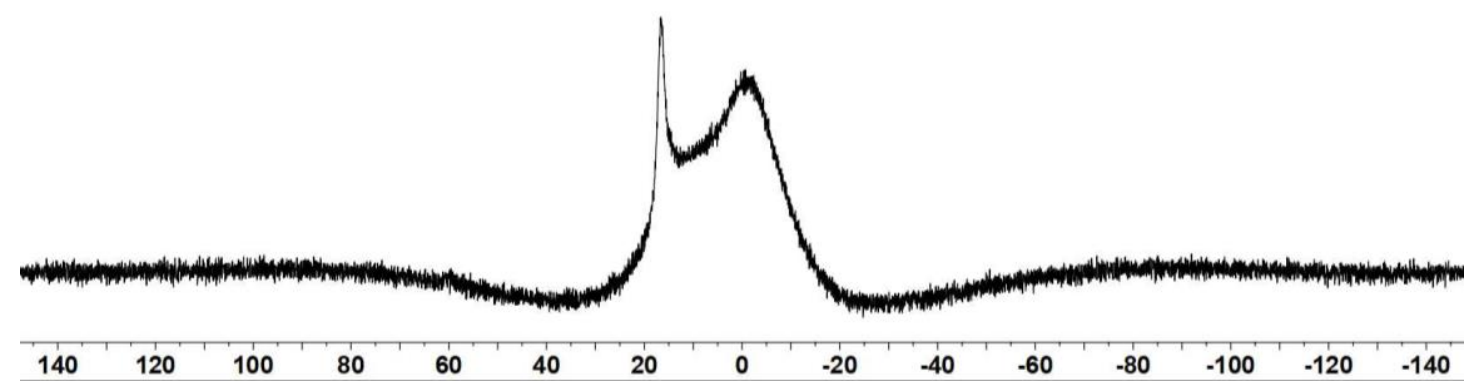

Figure 80. ${ }^{11} \mathrm{~B}\left\{{ }^{1} \mathrm{H}\right\} \mathrm{NMR}\left(192 \mathrm{MHz}\right.$, methylene chloride- $\left.\mathrm{d}_{2}, 299 \mathrm{~K}\right)$ spectrum of compound $\mathbf{1 8 a}$.

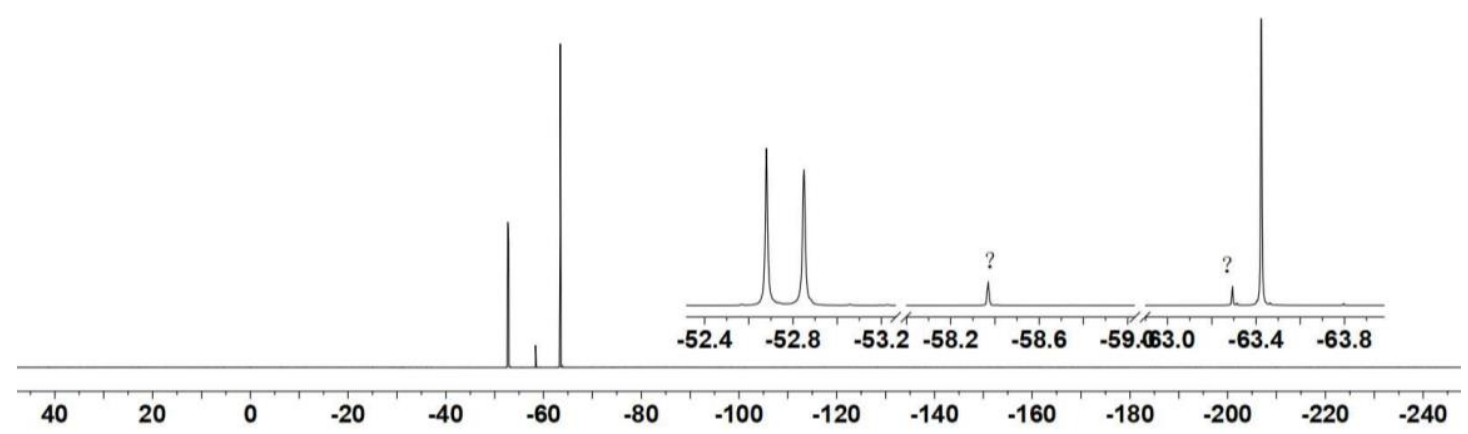

Figure 81. ${ }^{19} \mathrm{~F} \mathrm{NMR}\left(564 \mathrm{MHz}\right.$, methylene chloride- $\left.d_{2}, 268 \mathrm{~K}\right)$ spectrum of compound 18a. 


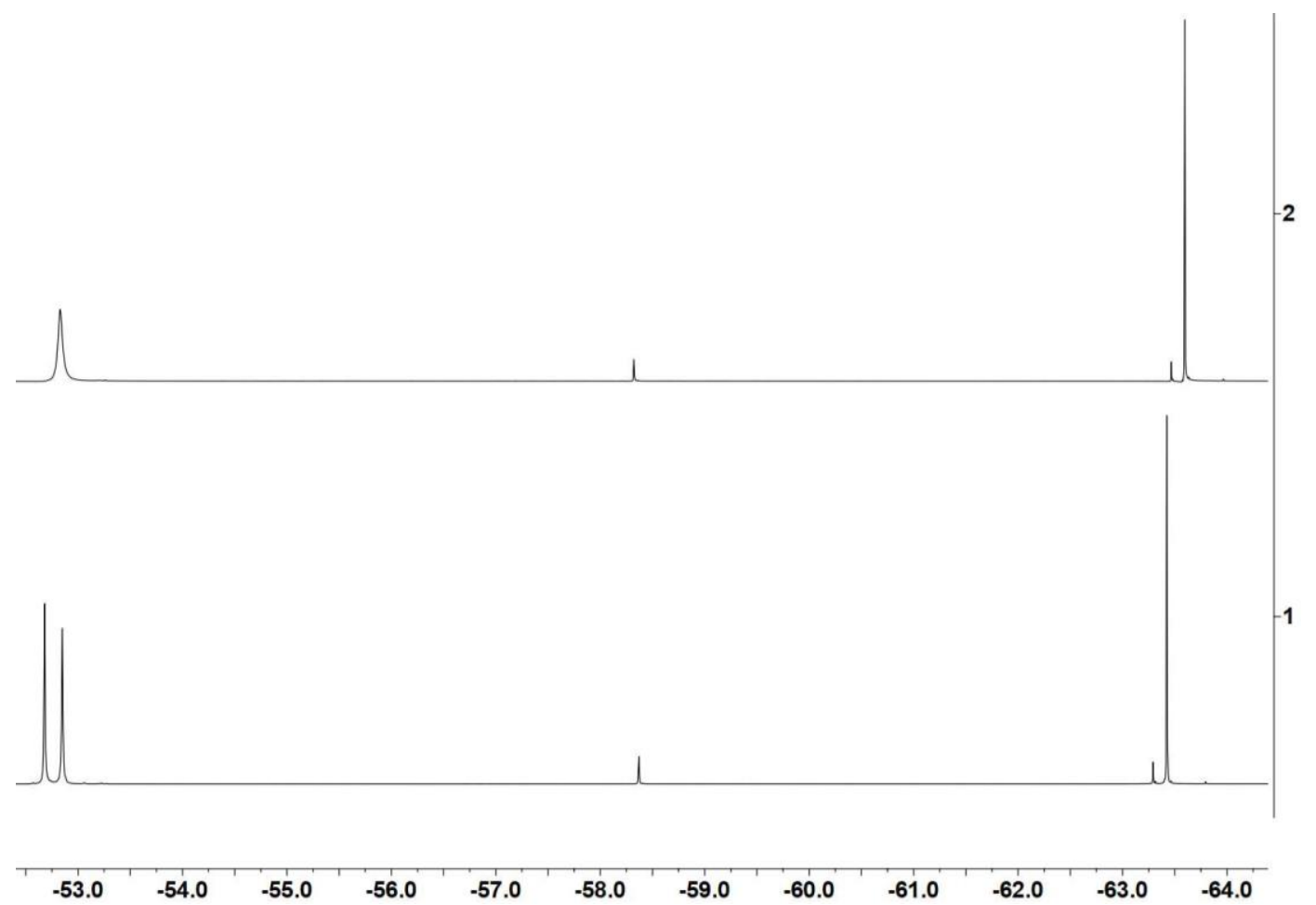

Figure 82. ${ }^{19} \mathrm{~F}$ NMR (564 MHz, methylene chloride- $d_{2}$ ) spectra of compound $18 \mathrm{a},(1)$ at $268 \mathrm{~K},(2)$ at 299 K.

Crystals suitable for the X-ray crystal structure analysis were obtained from a solution of 18a in pentane at room temperature.

X-ray crystal structure analysis of compound 18a (erk9646): A yellow plate-like specimen of $\mathrm{C}_{40} \mathrm{H}_{34} \mathrm{BF}$ IrN, approximate dimensions $0.030 \mathrm{~mm} \times 0.120 \mathrm{~mm} \times 0.140 \mathrm{~mm}$, was used for the X-ray crystallographic analysis. The X-ray intensity data were measured. A total of 1514 frames were collected. The total exposure time was 19.86 hours. The frames were integrated with the Bruker SAINT software package using a wide-frame algorithm. The integration of the data using a triclinic unit cell yielded a total of 25272 reflections to a maximum $\theta$ angle of $66.65^{\circ}$ ( $0.84 \AA$ resolution), of which 5721 were independent (average redundancy 4.417 , completeness $=99.2 \%, R_{\text {int }}=6.97 \%, R_{\text {sig }}$ $=5.60 \%)$ and $5056(88.38 \%)$ were greater than $2 \sigma\left(F^{2}\right)$. The final cell constants of $\underline{a}=8.6983(2) \AA, \underline{b}$ $=10.4210(2) \AA, \underline{c}=19.0291(4) \AA, \alpha=77.0000(10)^{\circ}, \beta=76.9460(10)^{\circ}, \gamma=82.3110(10)^{\circ}$, volume $=$ $1630.98(6) \AA^{3}$, are based upon the refinement of the XYZ-centroids of 9941 reflections above 20 $\sigma(\mathrm{I})$ with $9.109^{\circ}<2 \theta<133.2^{\circ}$. Data were corrected for absorption effects using the multi-scan method (SADABS). The ratio of minimum to maximum apparent transmission was 0.614 . The calculated minimum and maximum transmission coefficients (based on crystal size) are 0.3770 and 0.7810. The structure was solved and refined using the Bruker SHELXTL Software Package, using the space group $P-1$, with $\mathrm{Z}=2$ for the formula unit, $\mathrm{C}_{40} \mathrm{H}_{34} \mathrm{BF}_{9} \mid r N$. The final anisotropic full-matrix least-squares refinement on $\mathrm{F}^{2}$ with 471 variables converged at $\mathrm{R} 1=3.83 \%$, for the observed data and $w R 2=9.36 \%$ for all data. The goodness-of-fit was 1.115. The largest peak in the final difference electron density synthesis was $0.955 \mathrm{e}^{-} / \AA^{3}$ and the largest hole was $-1.351 \mathrm{e}^{-} / \AA^{3}$ with an RMS deviation of $0.160 \mathrm{e}^{-} / \AA^{3}$. On the basis of the final model, the calculated density was $1.838 \mathrm{~g} / \mathrm{cm}^{3}$ and F(000), $888 \mathrm{e}^{-}$. CCDC number: 2007641. 


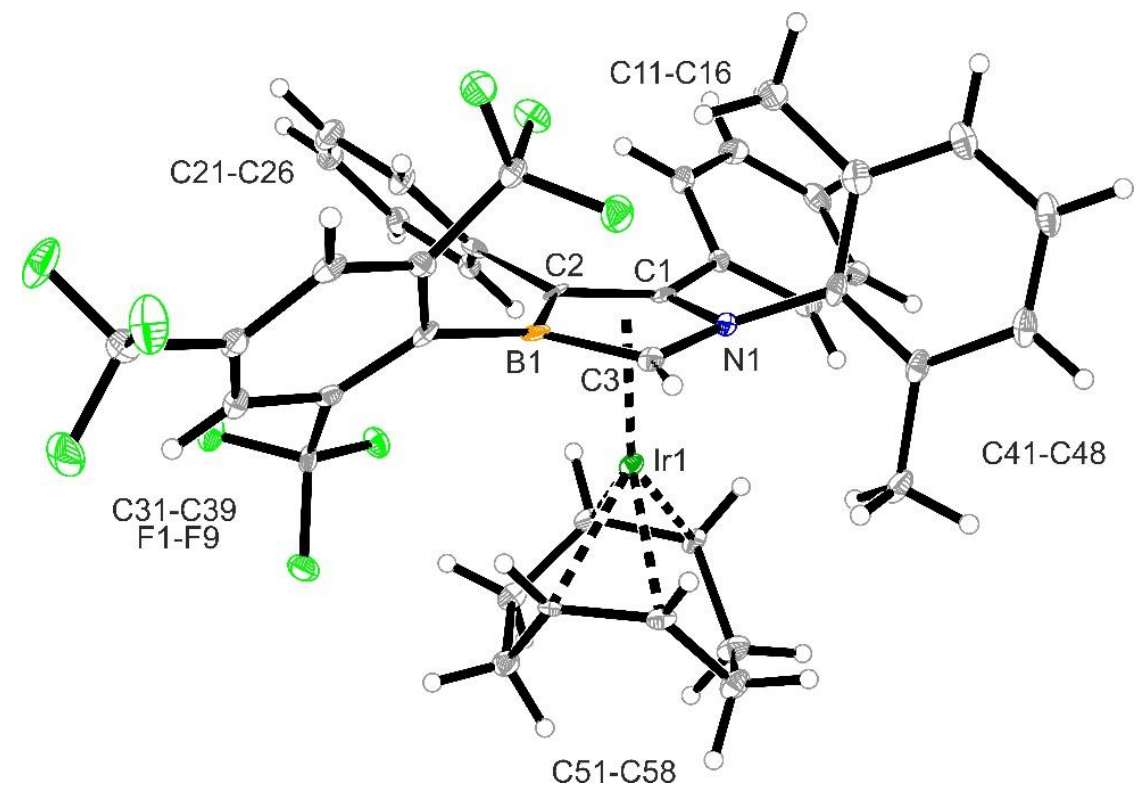

Figure S83. Crystal structure of compound 18a (thermal ellipsoids at 30\% probability).

\section{Preparation of compound $18 \mathrm{~b}$}

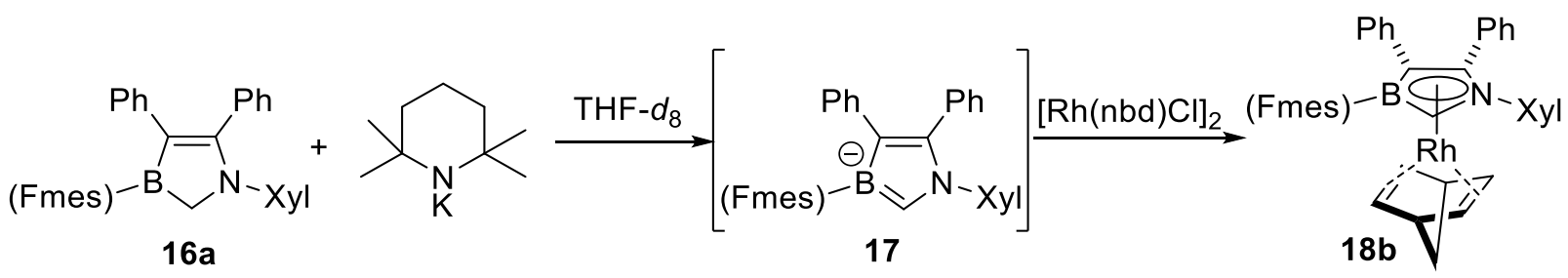

Scheme S15.

In a J. Young tube, KTMP ( $35.9 \mathrm{mg}, 2 \mathrm{mmol}, 2$ equiv.) was added to a solution of azaborole 16a (60.3 mg, $1 \mathrm{mmol}, 1$ equiv.) in THF- $d_{8}$ to give a deep brown solution. The resulting solution was stored at room temperature for $30 \mathrm{~min}$. Then $[\mathrm{Rh}(\mathrm{nbd}) \mathrm{Cl}]_{2}(23.0 \mathrm{mg}, 0.5 \mathrm{mmol}, 1$ equiv.) was added and the resulting mixture was stored overnight. All the volatiles were removed in vacuo, the residue was dispersed in pentane $(15 \mathrm{~mL})$ and the solid was filtered off. The solution was concentrated to ca. $1 \mathrm{~mL}$ and stored in $-35^{\circ} \mathrm{C}$ to finally give compound $18 \mathrm{~b}$ as yellow crystalline solid (34 mg, $42 \%$ yield).

Elemental Analysis for $\mathrm{C}_{39} \mathrm{H}_{30} \mathrm{BNF}_{9} \mathrm{Rh}$ : calc. C (58.75\%), H (3.79\%), N (1.76 \%); found: C (58.58 \%), H (4.09\%), N (1.99\%)

${ }^{1} \mathrm{H}$ NMR $\left(600 \mathrm{MHz}\right.$, methylene chloride- $\left.d_{2}, 183 \mathrm{~K}\right): \delta=8.16\left(\mathrm{~s}, 1 \mathrm{H}, m\right.$-Fmes), $8.04\left(\mathrm{~s}, 1 \mathrm{H}, m^{\prime}\right.$-Fmes), $7.43\left(\mathrm{~m}, 1 \mathrm{H}, o-\mathrm{Ph}^{\mathrm{N}}\right), 7.14\left(\mathrm{~d},{ }^{3}{ }_{\mathrm{HH}}=7.8 \mathrm{~Hz}, 1 \mathrm{H}, o-\mathrm{Xyl}\right),[7.05(\mathrm{~m}, 6 \mathrm{H}), 6.92(\mathrm{~m}, 3 \mathrm{H})]\left(p-\mathrm{Xyl}, o^{\prime}-\mathrm{Ph}^{\mathrm{N}}, m-\right.$ $\left.\mathrm{Ph}^{\mathrm{N}}, m^{\prime}-\mathrm{Ph}^{\mathrm{N}}, p-\mathrm{Ph}^{\mathrm{N}}, o-\mathrm{Ph}^{\mathrm{B}}, m-\mathrm{Ph}^{\mathrm{B}}, m^{\prime}-\mathrm{Ph}^{\mathrm{B}}, p-\mathrm{Ph}^{\mathrm{B}}\right), 6.70\left(\mathrm{~d},{ }^{3} \mathrm{JHH}_{\mathrm{HH}}=7.6 \mathrm{~Hz}, 1 \mathrm{H}, m^{\prime}-\mathrm{Xyl}\right), 6.25\left(\mathrm{~m}, 1 \mathrm{H}, o^{\prime}-\right.$ $\left.\mathrm{Ph}^{\mathrm{B}}\right), 4.28(\mathrm{~s}, 1 \mathrm{H}, \mathrm{CH}),[3.93,3.33,3.30,3.17]\left(\right.$ each $\mathrm{s}$, each $\left.1 \mathrm{H}, \mathrm{CH}={ }^{\mathrm{nbd}}\right),[3.72,3.42]($ each $\mathrm{s}$, each 1 $\left.\mathrm{H}, \mathrm{CH}^{\mathrm{nbd}}\right), 3.47\left(\mathrm{~s}, 3 \mathrm{H}, o-\mathrm{CH}_{3}{ }^{\mathrm{Xyl}}\right), 1.60\left(\mathrm{~s}, 3 \mathrm{H}, \mathrm{o}^{\prime}-\mathrm{CH}_{3} \mathrm{Xy}\right),\left[1.07\left(\mathrm{AB},{ }^{2} \mathrm{~J}_{\mathrm{HH}}=8.3 \mathrm{~Hz}, 1 \mathrm{H}\right), 1.00\left(\mathrm{AB},{ }^{2} \mathrm{JHH}_{\mathrm{HH}}=\right.\right.$ $8.1 \mathrm{~Hz}, 1 \mathrm{H})]\left(\mathrm{CH}_{2}{ }^{\mathrm{nbd}}\right)$.

${ }^{13} \mathrm{C}\left\{{ }^{1} \mathrm{H}\right\}$ NMR $\left(151 \mathrm{MHz}\right.$, methylene chloride- $\left.d_{2}, 183 \mathrm{~K}\right)$ [selected resonances]: $\delta=143.2$ (br, i-Fmes), [139.6, 130.15](i- $\left.\mathrm{Ph}^{\mathrm{N}}, i-\mathrm{Ph}^{\mathrm{B}}\right), 136.9$ (o'-Xyl), 134.6 (o-Xyl), 133.2 (i-Xyl), [132.1, 129.0, 127.47, 
$127.35,126.5,126.32,126.25,123.8]\left(p-\mathrm{Xyl}^{\prime}, o^{\prime}-\mathrm{Ph}^{\mathrm{N}}, m-\mathrm{Ph}^{\mathrm{N}}, m^{\prime}-\mathrm{Ph}^{\mathrm{N}}, p-\mathrm{Ph}^{\mathrm{N}}, o-\mathrm{Ph}^{\mathrm{B}}, m-\mathrm{Ph}^{\mathrm{B}}, m^{\prime}-\mathrm{Ph}^{\mathrm{B}}, p-\right.$ $\left.\mathrm{Ph}^{\mathrm{B}}\right) 130.05\left(o-\mathrm{Ph}^{\mathrm{N}}\right), 128.22\left(m^{\prime}-\mathrm{Xyl}\right), 128.16\left(m-\mathrm{Xyl}, o^{\prime}-\mathrm{Ph}^{\mathrm{B}}\right), 127.41$ (br, $m$-Fmes), $125.2\left(\mathrm{br}, m^{\prime}-\right.$ Fmes), , 117.7 ( $\mathrm{NC}=), 111.6(\mathrm{br}, \mathrm{BC}=), 92.7(\mathrm{br}, \mathrm{CH}), 57.8\left(\mathrm{CH}_{2}^{\mathrm{nbd}}\right),[57.0,51.2,44.8,38.9]\left(\mathrm{CH}={ }^{\mathrm{nbd}}\right)$, $[49.0,48.2]\left(\mathrm{CH}^{\mathrm{nbd}}\right), 18.6\left(0-\mathrm{CH}_{3}{ }^{\mathrm{Xy}}\right), 17.0\left(o^{\prime}-\mathrm{CH}_{3}{ }^{\mathrm{Xy}}\right)$.

${ }^{11} \mathrm{~B}\left\{{ }^{1} \mathrm{H}\right\}$ NMR $\left(192 \mathrm{MHz}\right.$, methylene chloride- $\left.d_{2}, 299 \mathrm{~K}\right): \delta=17.2\left(\mathrm{v}_{1 / 2} \approx 240 \mathrm{~Hz}\right)$.

${ }^{19} \mathrm{~F}$ NMR $\left(564 \mathrm{MHz}\right.$, methylene chloride- $\left.d_{2}, 263 \mathrm{~K}\right): \delta=[-52.2,-53.6]$ (each s, each $\left.1 \mathrm{~F}, o-\mathrm{CF}_{3}\right),-63.3(\mathrm{~s}$, $\left.1 \mathrm{~F}, p-\mathrm{CF}_{3}\right)$.
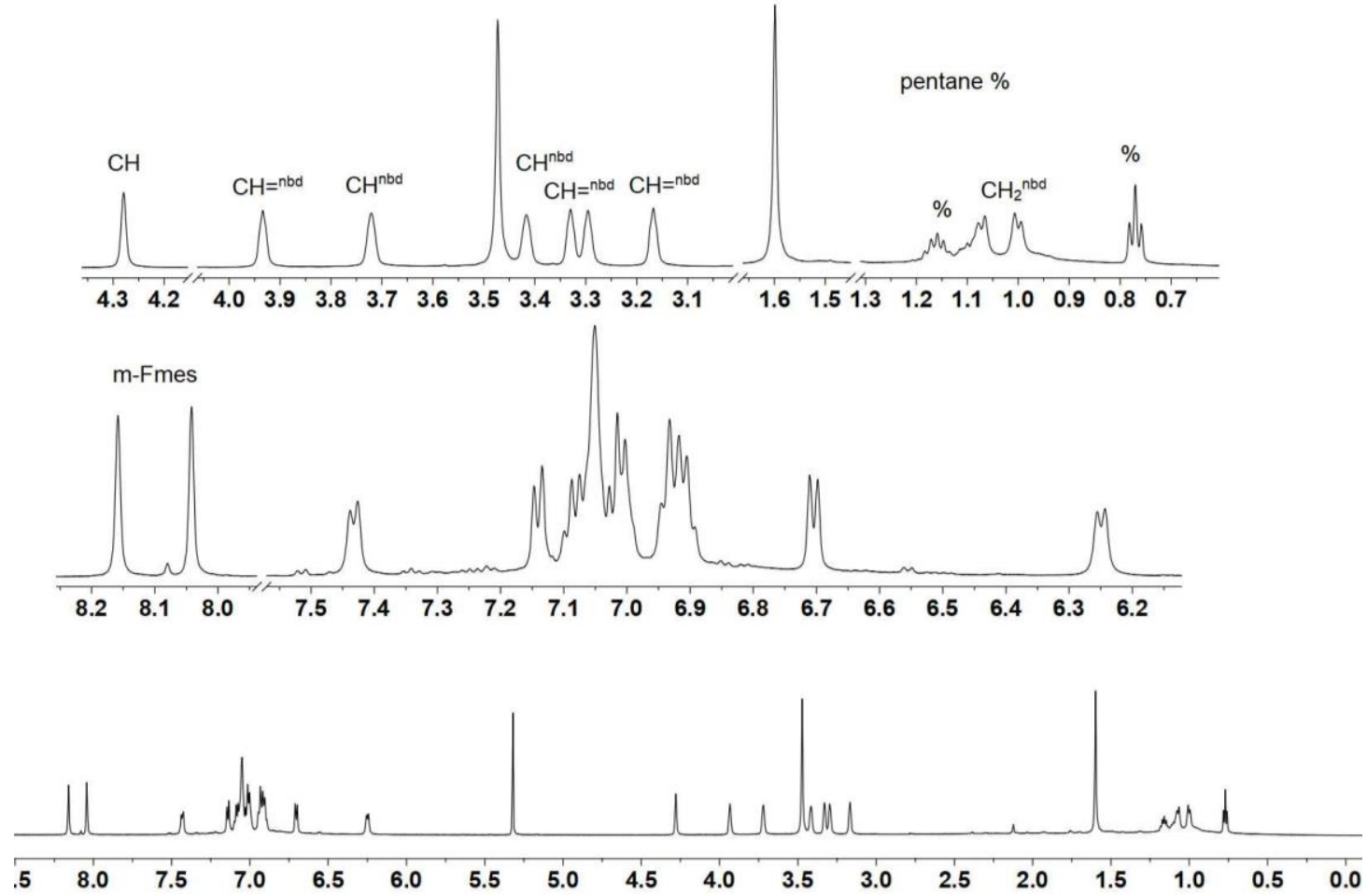

Figure S84. ${ }^{1} \mathrm{H}$ NMR (600 MHz, methylene chloride- $d_{2}, 183 \mathrm{~K}$ ) spectrum of compound $\mathbf{1 8 b}$.

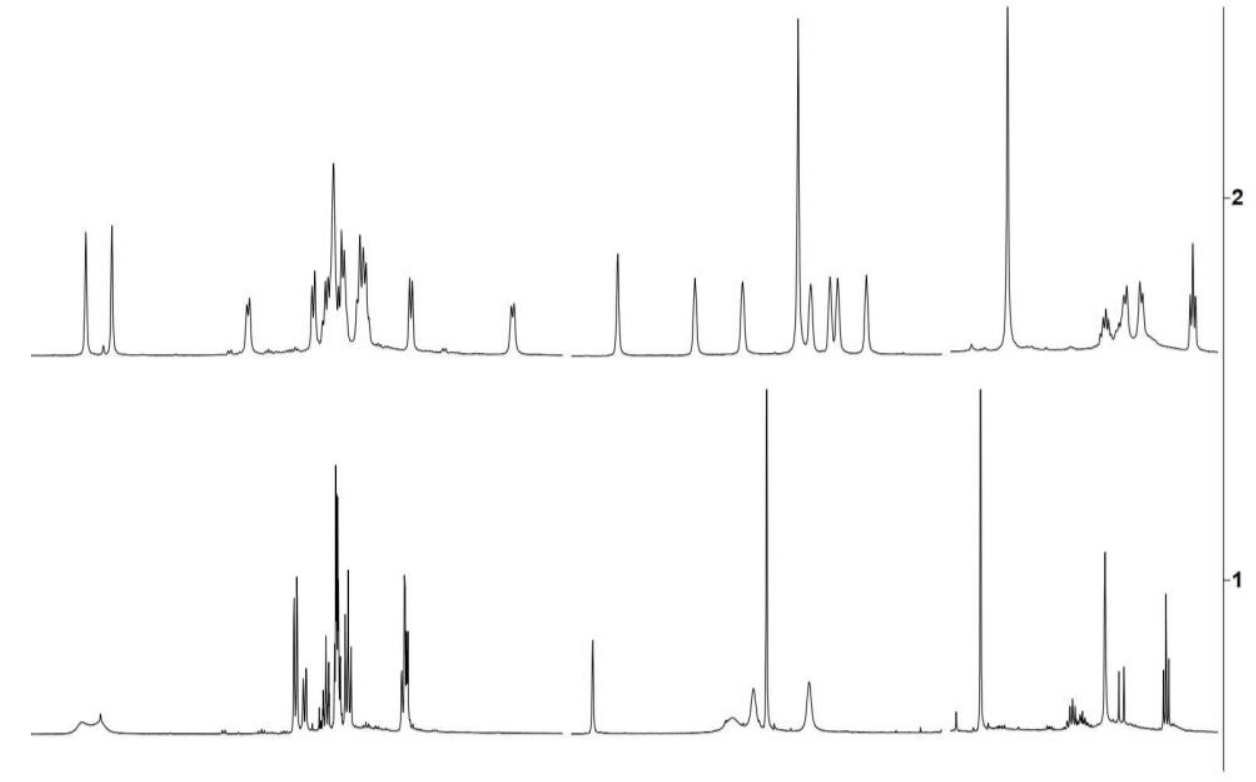

\begin{tabular}{lllllllllllllllllllllllllllllllll}
\hline 4 & 8.2 & 8.0 & 7.8 & 7.6 & 7.4 & 7.2 & 7.0 & 6.8 & 6.6 & 6.4 & 6.2 & 4.4 & 4.2 & 4.0 & 3.8 & 3.6 & 3.4 & 3.2 & 3.0 & 1.8 & 1.6 & 1.4 & 1.2 & 1.0 & 0.8
\end{tabular}

Figure S85. ${ }^{1} \mathrm{H}$ NMR (600 MHz, methylene chloride- $d_{2}$ ) spectra of compound $18 \mathrm{~b}$ : (1) at $299 \mathrm{~K},(2)$ at $183 \mathrm{~K}$. 


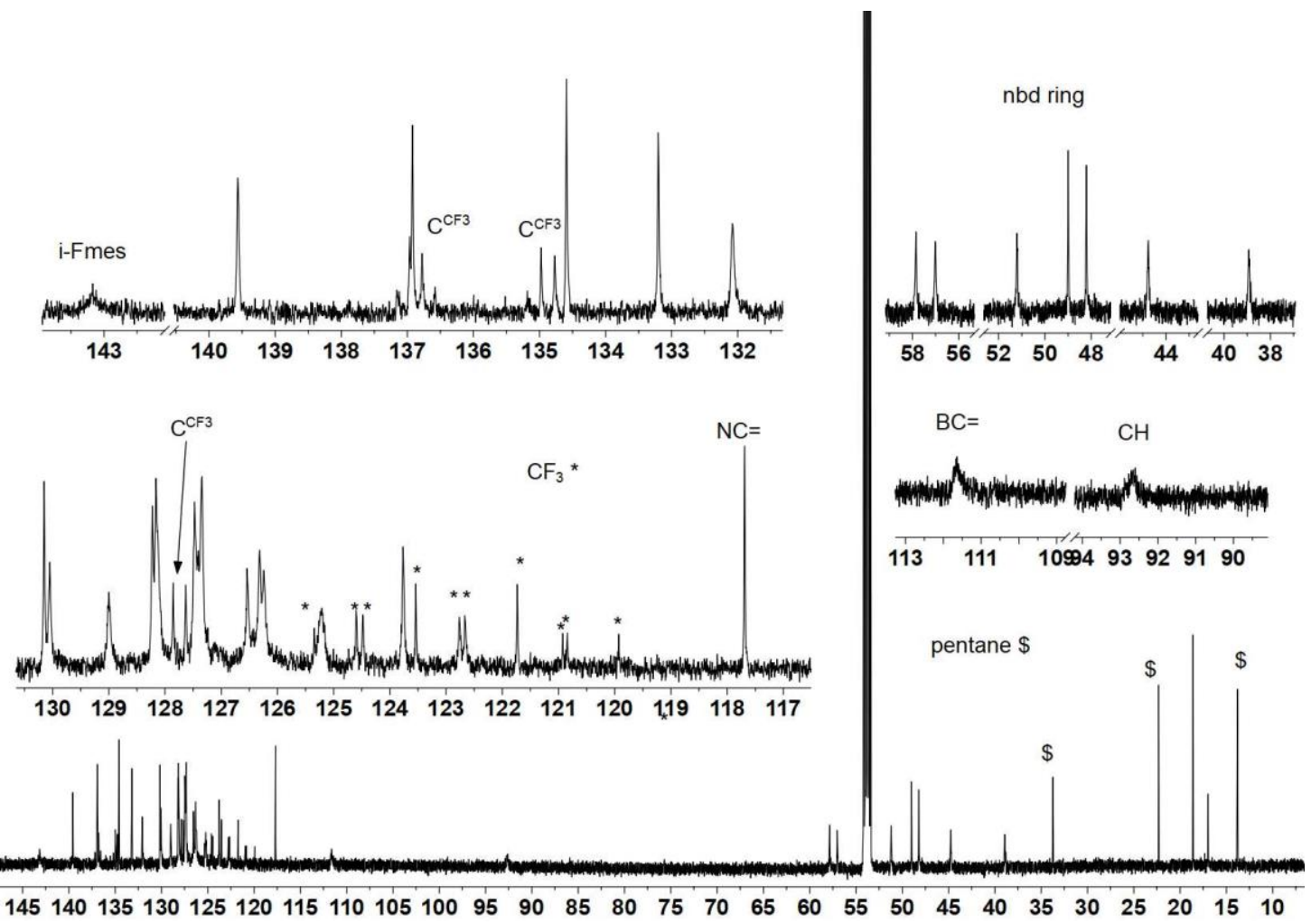

Figure S86. $\mathrm{C}^{13}\left\{{ }^{1} \mathrm{H}\right\} \mathrm{NMR}\left(151 \mathrm{MHz}\right.$, methylene chloride- $\left.d_{2}, 183 \mathrm{~K}\right)$ spectrum of compound $\mathbf{1 8 \mathbf { b }}$.

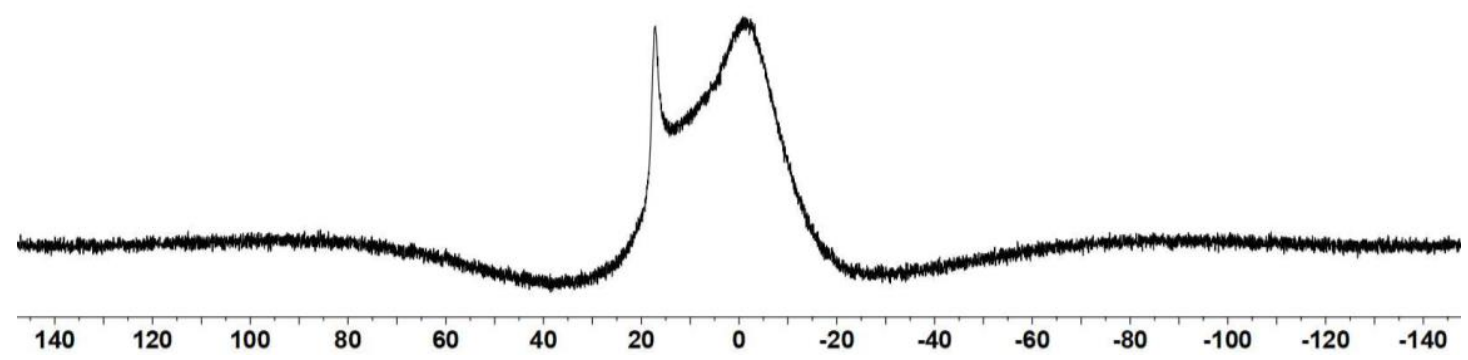

Figure S87. ${ }^{11} \mathrm{~B}\left\{{ }^{1} \mathrm{H}\right\}$ NMR (192 MHz, methylene chloride- $\left.d_{2}, 299 \mathrm{~K}\right)$ spectrum of compound $\mathbf{1 8 b}$.

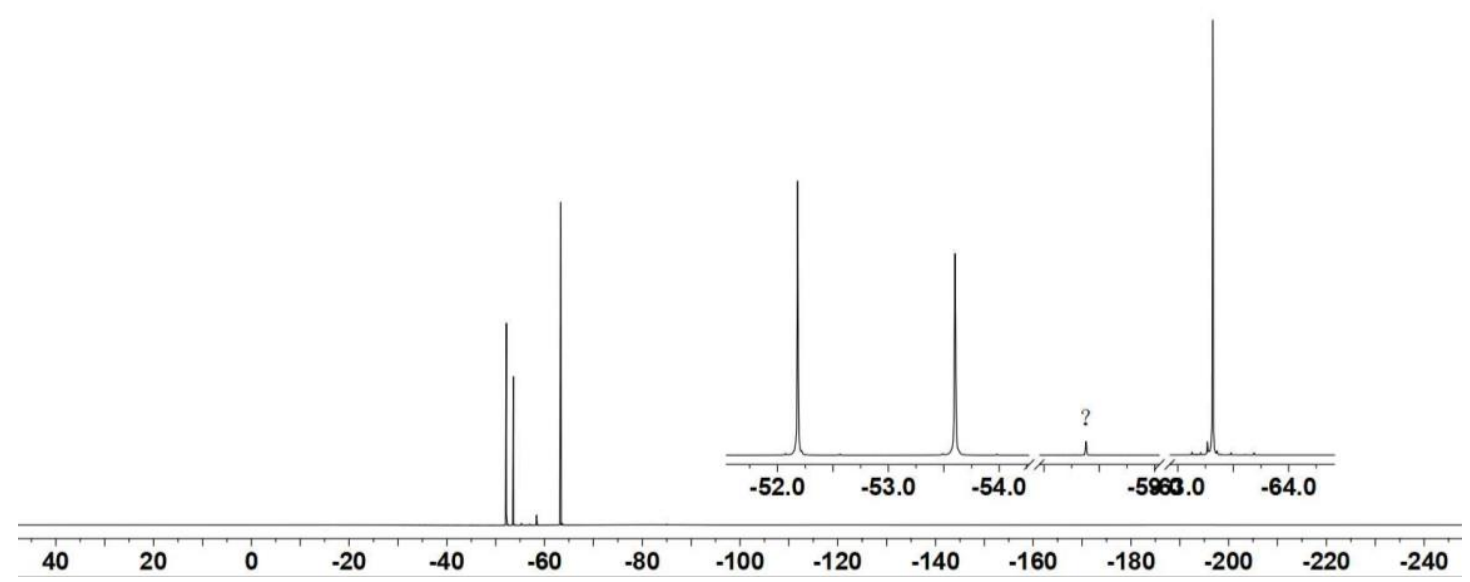

Figure S88. ${ }^{19} \mathrm{~F}$ NMR (564 MHz, methylene chloride- $d_{2}, 263 \mathrm{~K}$ ) spectrum of compound 18b. 


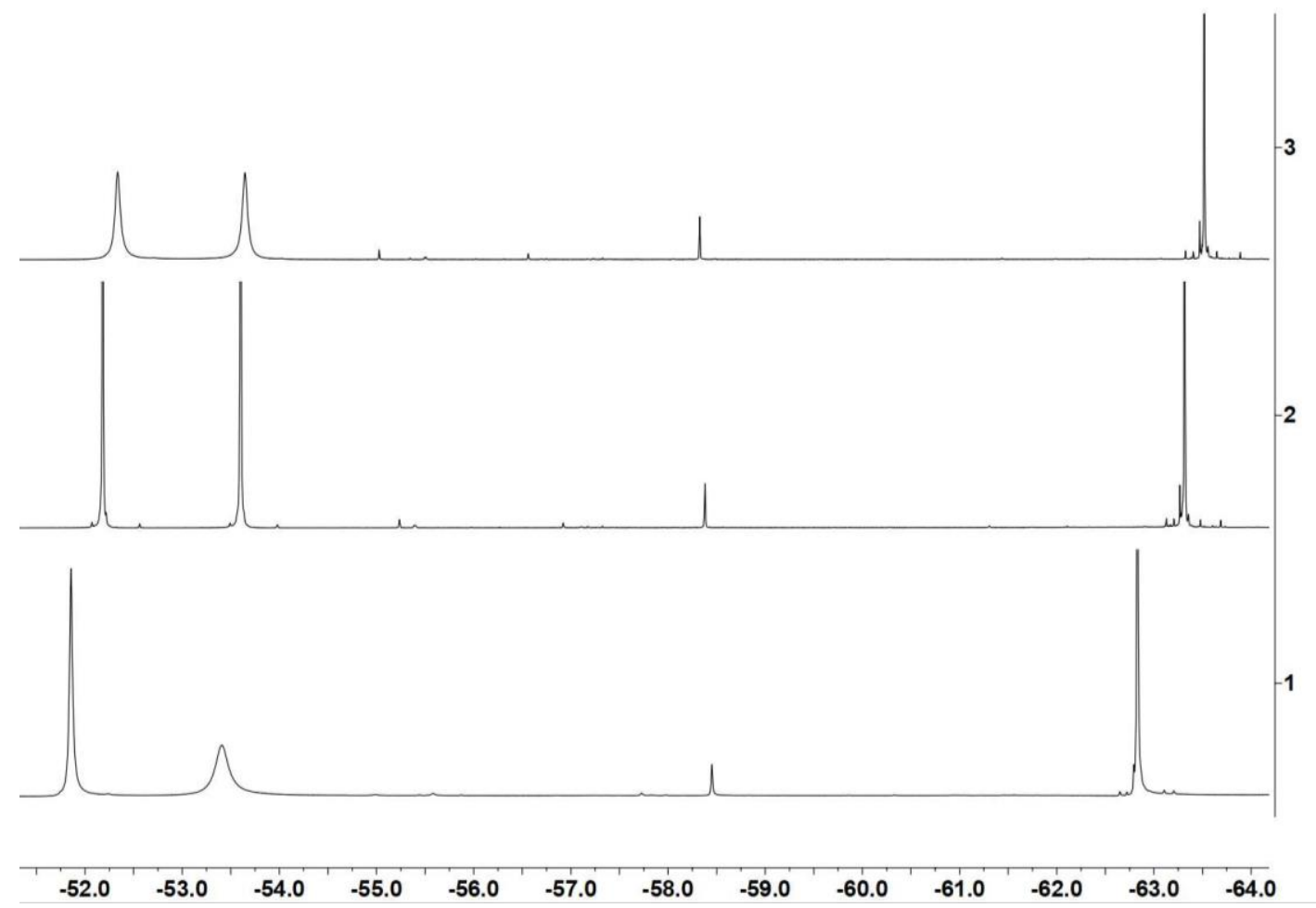

Figure S89. ${ }^{19} \mathrm{~F}$ NMR (564 MHz, methylene chloride- $d_{2}$ ) spectra of compound $18 \mathrm{~b}(1)$ at $183 \mathrm{~K},(2)$ at $263 \mathrm{~K}, 3)$ at $299 \mathrm{~K}$.

Crystals suitable for the X-ray crystal structure analysis were obtained from a solution of $\mathbf{1 8 b}$ in pentane at room temperature.

X-ray crystal structure analysis of compound 18b (erk9633): A yellow needle-like specimen of $\mathrm{C}_{39} \mathrm{H}_{30} \mathrm{BF}{ }_{9} \mathrm{NRh}$, approximate dimensions $0.043 \mathrm{~mm} \times 0.084 \mathrm{~mm} \times 0.261 \mathrm{~mm}$, was used for the X-ray crystallographic analysis. The X-ray intensity data were measured. A total of 622 frames were collected. The total exposure time was 3.97 hours. The frames were integrated with the Bruker SAINT software package using a narrow-frame algorithm. The integration of the data using a monoclinic unit cell yielded a total of 133048 reflections to a maximum $\theta$ angle of $25.35^{\circ}(0.83 \AA$ resolution), of which 12094 were independent (average redundancy 11.001 , completeness $=99.9 \%$, $\left.R_{\text {int }}=13.33 \%, R_{\text {sig }}=5.20 \%\right)$ and $9726(80.42 \%)$ were greater than $2 \sigma\left(F^{2}\right)$. The final cell constants of $\underline{a}=25.8026(13) \AA, \underline{b}=10.3993(5) \AA, \underline{c}=26.3164(13) \AA, \beta=110.600(2)^{\circ}$, volume $=6609.9(6) \AA^{3}$, are based upon the refinement of the $X Y Z$-centroids of 9916 reflections above $20 \sigma(\mathrm{I})$ with $4.737^{\circ}<2 \theta$ $<52.83^{\circ}$. Data were corrected for absorption effects using the multi-scan method (SADABS). The ratio of minimum to maximum apparent transmission was 0.939 . The calculated minimum and maximum transmission coefficients (based on crystal size) are 0.8590 and 0.9750 . The structure was solved and refined using the Bruker SHELXTL Software Package, using the space group $P 2_{1} / n$, with $\mathrm{Z}=8$ for the formula unit, $\mathrm{C}_{39} \mathrm{H}_{30} \mathrm{BF}_{9} \mathrm{NRh}$. The final anisotropic full-matrix least-squares refinement on $\mathrm{F}^{2}$ with 923 variables converged at $\mathrm{R} 1=4.32 \%$, for the observed data and $\mathrm{WR} 2=$ $8.82 \%$ for all data. The goodness-of-fit was 1.047 . The largest peak in the final difference electron density synthesis was $0.670 \mathrm{e}^{-} / \AA^{3}$ and the largest hole was $-0.683 \mathrm{e}^{-} / \AA^{3}$ with an RMS deviation of $0.092 \mathrm{e}^{-} / \AA^{3}$. On the basis of the final model, the calculated density was $1.602 \mathrm{~g} / \mathrm{cm}^{3}$ and $F(000)$, $3216 \mathrm{e}^{-}$. CCDC number: 2007642. 


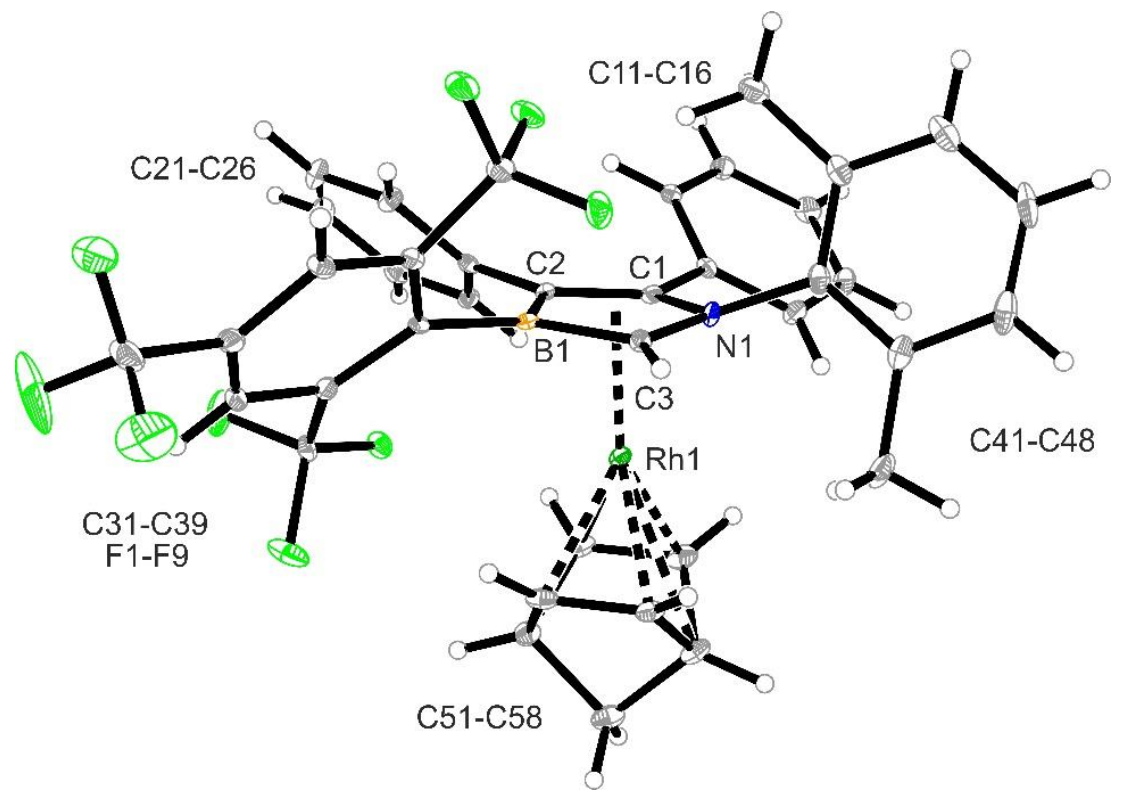

Figure S90. Crystal structure of compound $\mathbf{1 8 b}$ (thermal ellipsoids at $30 \%$ probability).

\section{Catalytic hydrogenation of alkenes and alkynes using complexes $18 \mathrm{a}, \mathrm{b}$}

\section{General procedure:}

In a glovebox with an argon atmosphere, complex $18 \mathrm{a}$ or $\mathbf{1 8 b}(0.005 \mathrm{mmol}, 1 \mathrm{~mol} \%)$ and the respective unsaturated substrate $(0.5 \mathrm{mmol})$, were mixed in C6D6 $(1 \mathrm{~mL})$. Then the reaction Schlenk tube was degassed and $\mathrm{H}_{2}$ (1.0 bar, r.t.) was introduced and stirred overnight at room temperature. Subsequently, Ferrocene $(18.6 \mathrm{mg}, 0.1 \mathrm{mmol}, 0.2$ equiv.) was added as internal standard and the resulting mixture was transferred to an NMR tube and monitored by ${ }^{1} \mathrm{H}$ NMR. The conversion was determined by integration of a suitable ${ }^{1} \mathrm{H}$ NMR resonance relative to ferrocene.

$$
\mathrm{Ph}=\mathrm{Ph}
$$

$76 \%$ Stilbene 4\% 1,2-diphenylethane<smiles>C=Cc1ccccc1</smiles>

$94 \%$ yield

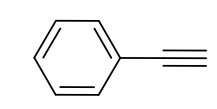

$37 \%$ styrene $3 \%$ ethyl benzene<smiles>C1=CCCCC1</smiles>

$117 \%$ yield (overlapping with $\mathrm{C}_{6} \mathrm{D}_{6} \mathrm{H}_{6}$ )

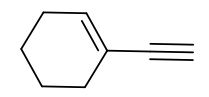

$22 \%$ diene product<smiles>O=C(/C=C/c1ccccc1)c1ccccc1</smiles>

$90 \%$ yield

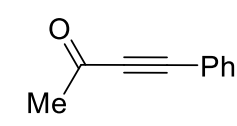

$35 \%$ double bond product $14 \%$ single bond product

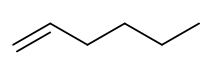

$22 \%$ yield

Scheme S16. Overview of catalytic hydrogenation of various substrates with complex 18a. 


$$
\mathrm{Ph}=\mathrm{Ph}
$$

$26 \%$ Stilbene

$8 \%$ 1,2-diphenylethane<smiles>C=Cc1ccccc1</smiles>

$100 \%$

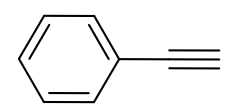

No product<smiles>C1=CCCCC1</smiles>

$106 \%$ (overlapping with $\mathrm{C}_{6} \mathrm{D}_{6} \mathrm{H}_{6}$ )

Scheme S17. Overview of catalytic hydrogenation of various substrates with complex $\mathbf{1 8 b}$.

Experiment 1: Hydrogenation of 1,2-diphenylacetylene in the presence of the Ir complex 18a.

$$
\mathrm{Ph}=\mathrm{Ph} \underset{\mathrm{C}_{6} \mathrm{D}_{6}, \text { r.t., overnight }}{\stackrel{18 \mathrm{a}(1 \mathrm{~mol} \%), \mathrm{H}_{2}(1.0 \mathrm{bar})}{\longrightarrow}} \underset{\mathrm{Ph}}{\longrightarrow} \overbrace{\mathrm{Ph}}+\mathrm{Ph}_{\mathrm{Ph}}
$$

\section{Scheme S18.}

Following the general procedure, the conversion to stilbene and 1,2-diphenylethane were 76\% and $4 \%$ based on ${ }^{1} \mathrm{H}$ NMR relative to ferrocene, respectively.

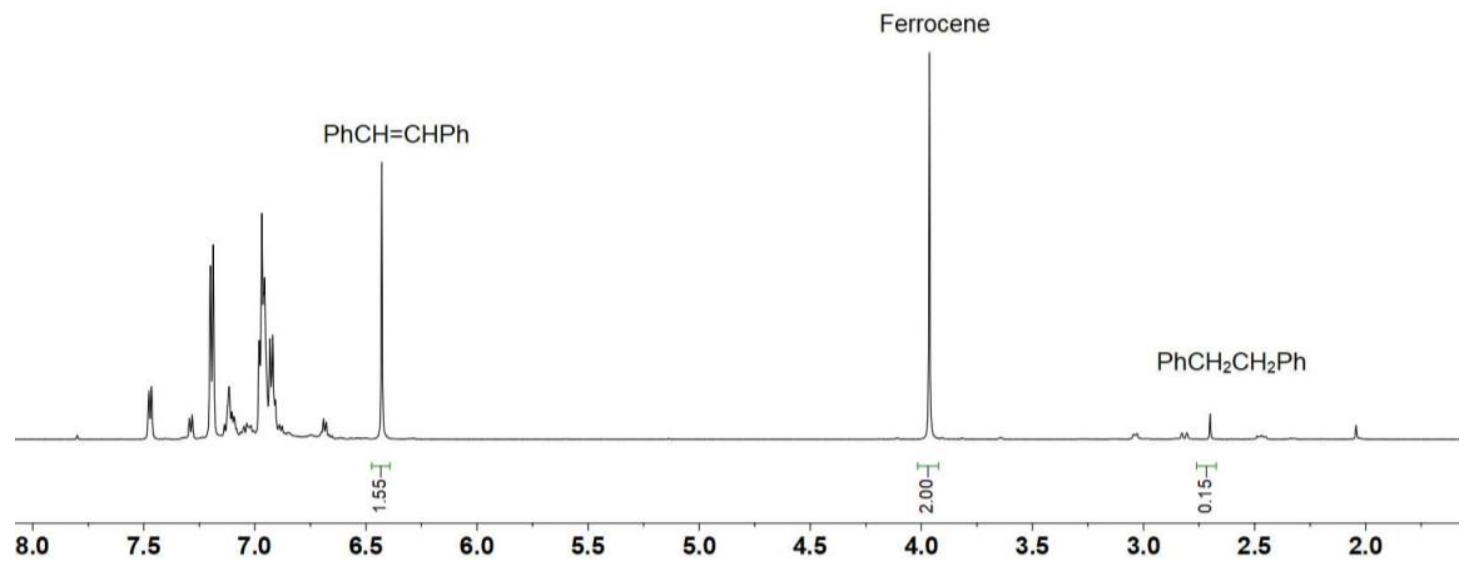

Figure S91. ${ }^{1} \mathrm{H}$ NMR (600 MHz, $\left.\mathrm{C}_{6} \mathrm{D}_{6}, 299 \mathrm{~K}\right)$ spectra of the obtained reaction mixture.

Experiment 2: Hydrogenation of phenylacetylene in the presence of the Ir complex 18a.

$$
\mathrm{Ph} \rightleftharpoons \underset{\mathrm{C}_{6} \mathrm{D}_{6}, \text { r.t., overnight }}{\stackrel{18 \mathrm{a}(1 \mathrm{~mol} \%), \mathrm{H}_{2}(1.0 \text { bar })}{\longrightarrow}}
$$

\section{Scheme S19.}

Following the general procedure, the conversion to styrene and ethylbenzene were $35 \%$ and $3 \%$ based on ${ }^{1} \mathrm{H}$ NMR relative to ferrocene, respectively. 


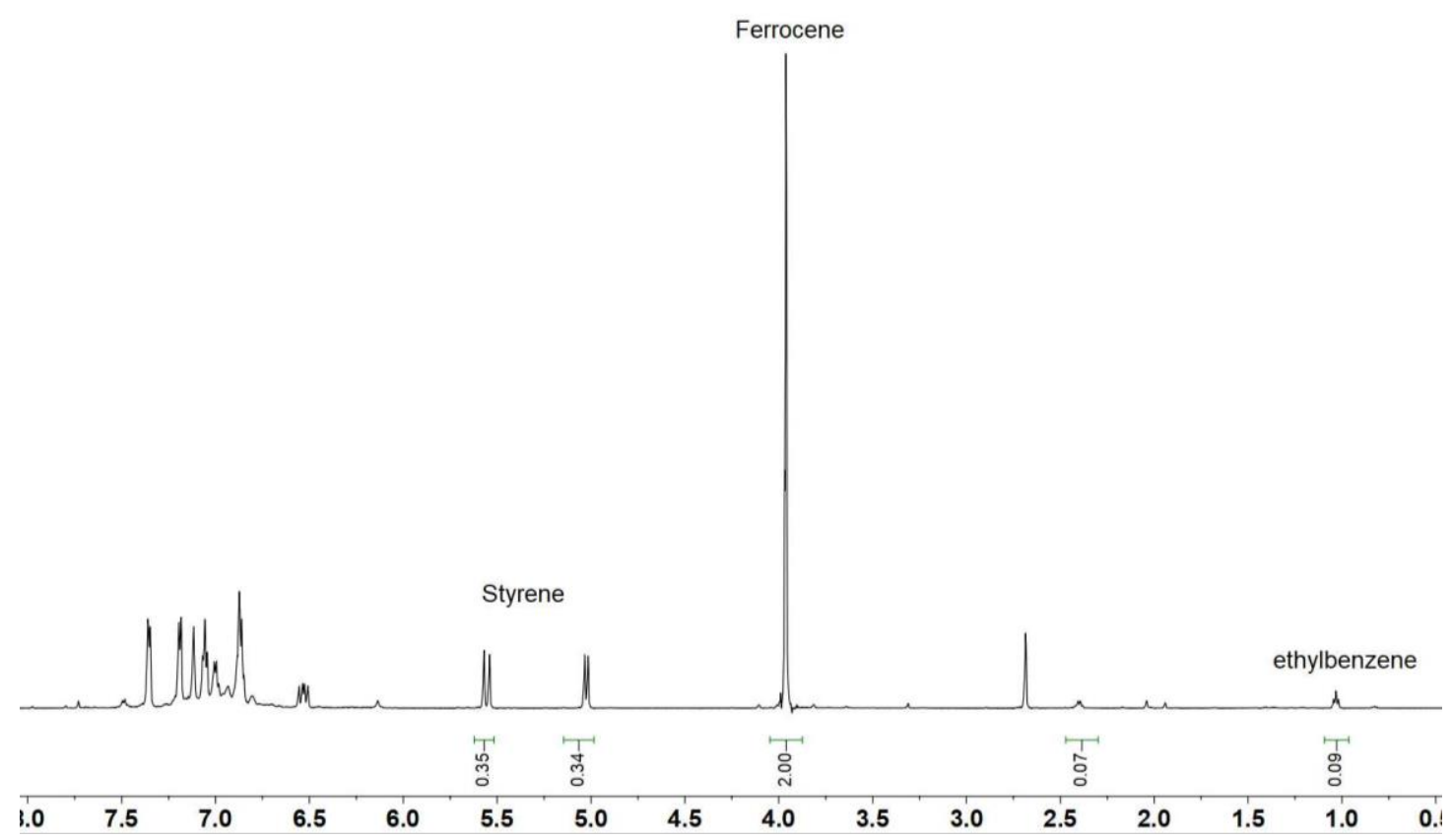

Figure S92. ${ }^{1} \mathrm{H}$ NMR (600 MHz, $\left.\mathrm{C}_{6} \mathrm{D}_{6}, 299 \mathrm{~K}\right)$ spectra of the obtained reaction mixture.

Experiment 3: Hydrogenation of 1-ethynylcyclohex-1-ene in the presence of the Ir complex $\mathbf{1 8 a .}$

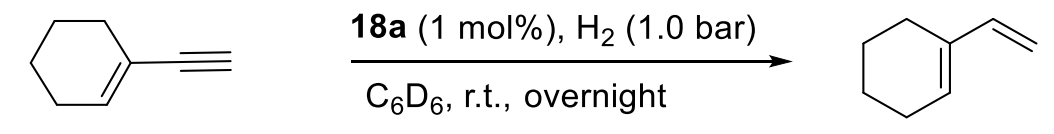

Scheme S20.

Following the general procedure, the conversion to 1 -vinylcyclohex-1-ene was $22 \%$ based on ${ }^{1} \mathrm{H}$ NMR relative to ferrocene.

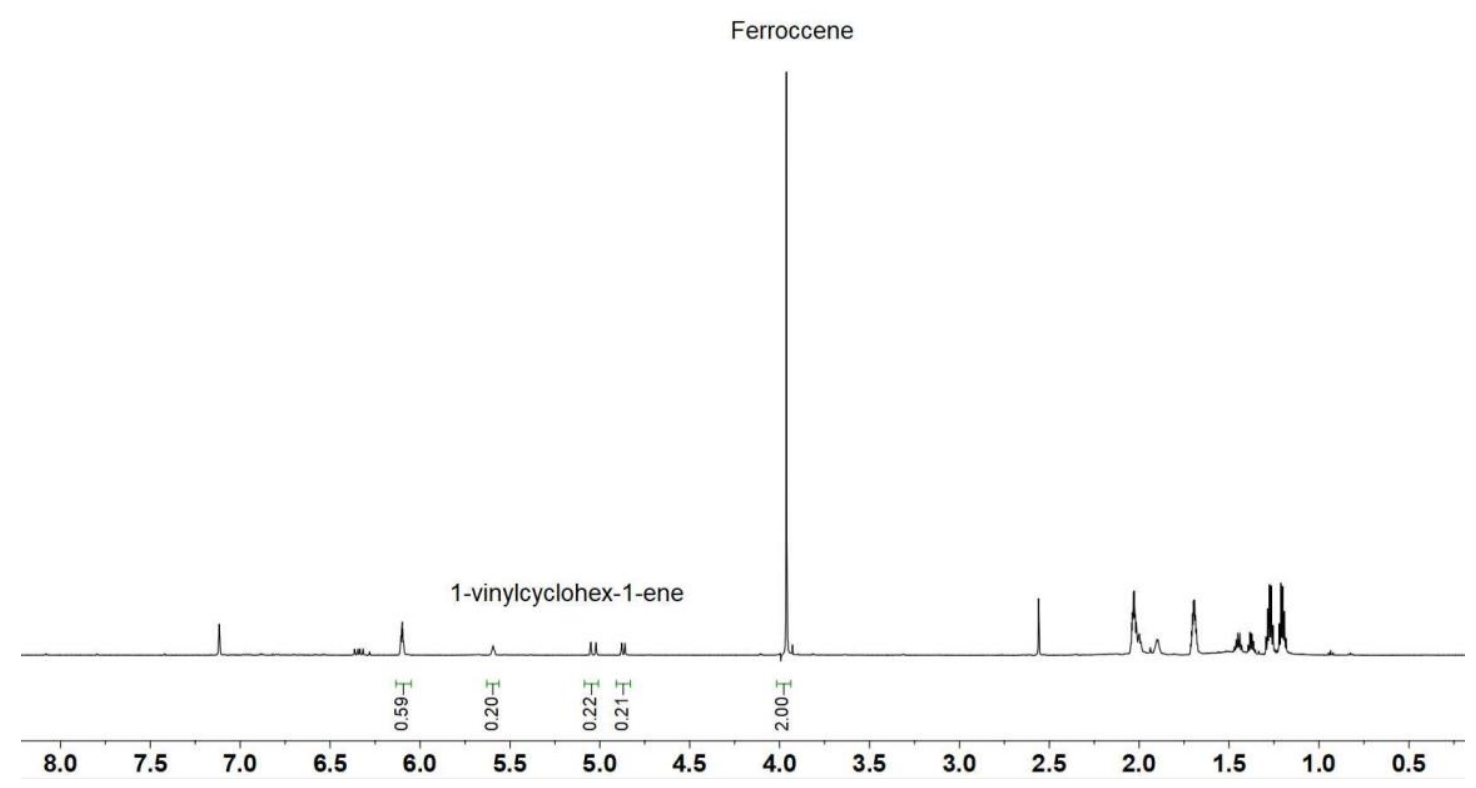

Figure S93. ${ }^{1} \mathrm{H}$ NMR (600 MHz, $\left.\mathrm{C}_{6} \mathrm{D}_{6}, 299 \mathrm{~K}\right)$ spectra of the obtained reaction mixture. 
Experiment 4: Hydrogenation of 4-phenylbut-3-yn-2-one in the presence of the Ir complex 18a.

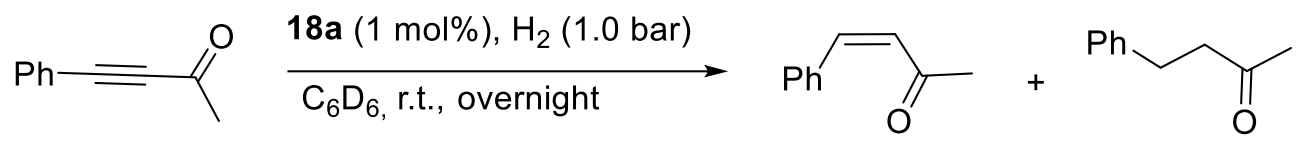

\section{Scheme S21.}

Following the general procedure, the conversion to cis-4-phenylbut-3-yn-2-one $\left(-\mathrm{CH}=\mathrm{CH}-{ }^{3} \mathrm{~J}_{\mathrm{HH}}=\right.$ $12.75 \mathrm{~Hz}$ ) and 4-phenylbutan-2-one were $35 \%$ and $14 \%$ based on ${ }^{1} \mathrm{H}$ NMR relative to ferrocene, respectively.

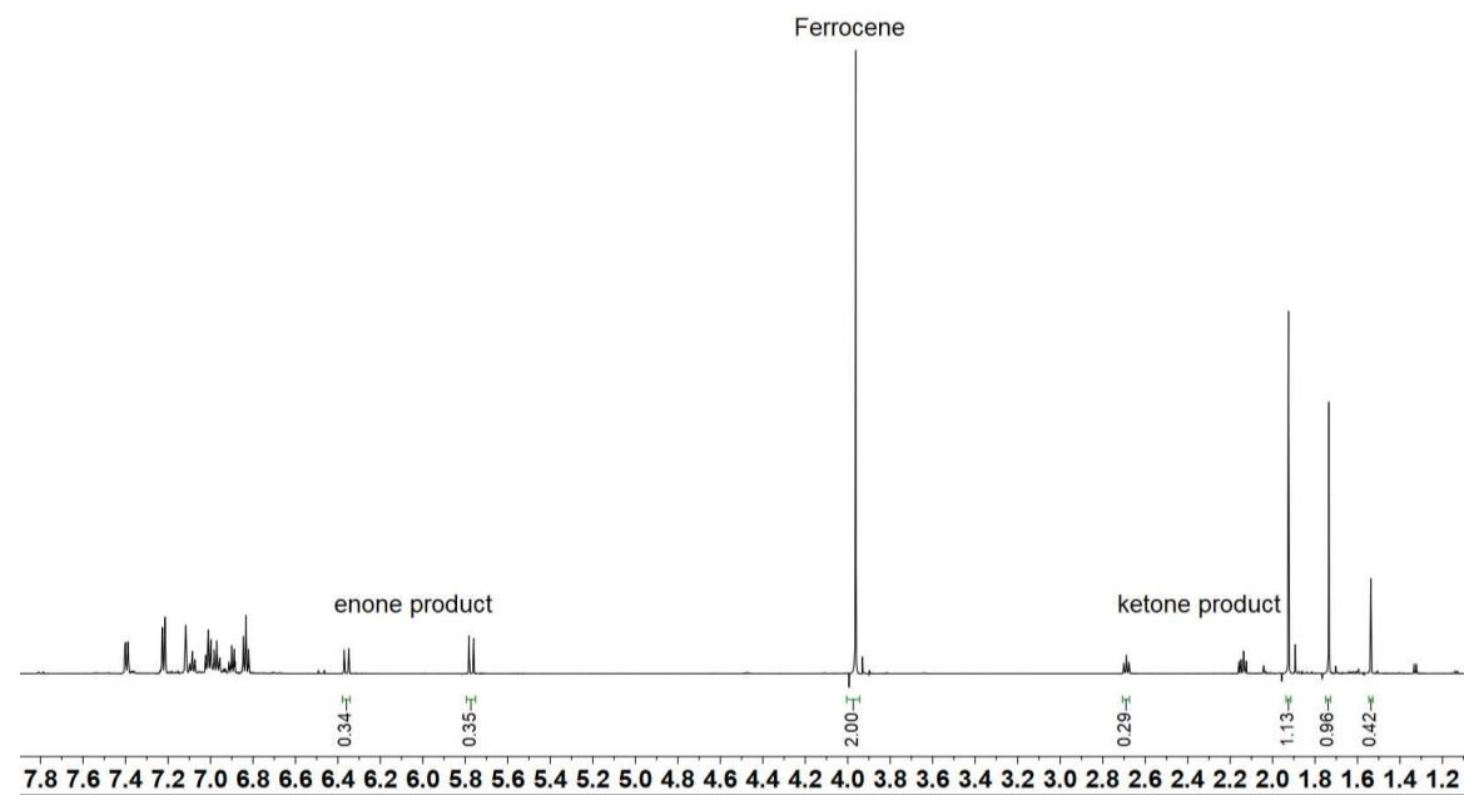

Figure S94. ${ }^{1} \mathrm{H}$ NMR (600 MHz, $\left.\mathrm{C}_{6} \mathrm{D}_{6}, 299 \mathrm{~K}\right)$ spectra of the obtained reaction mixture.

Experiment 5: Hydrogenation of styrene in the presence of the Ir complex 18a.

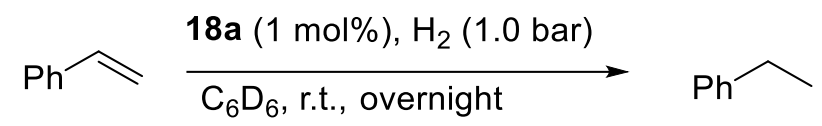

Scheme S22.

Following the general procedure, the conversion to ethylbenzene was $93 \%$ based on ${ }^{1} \mathrm{H}$ NMR relative to ferrocene.

[Comment: After the reaction, metal precipitate was observed.] 


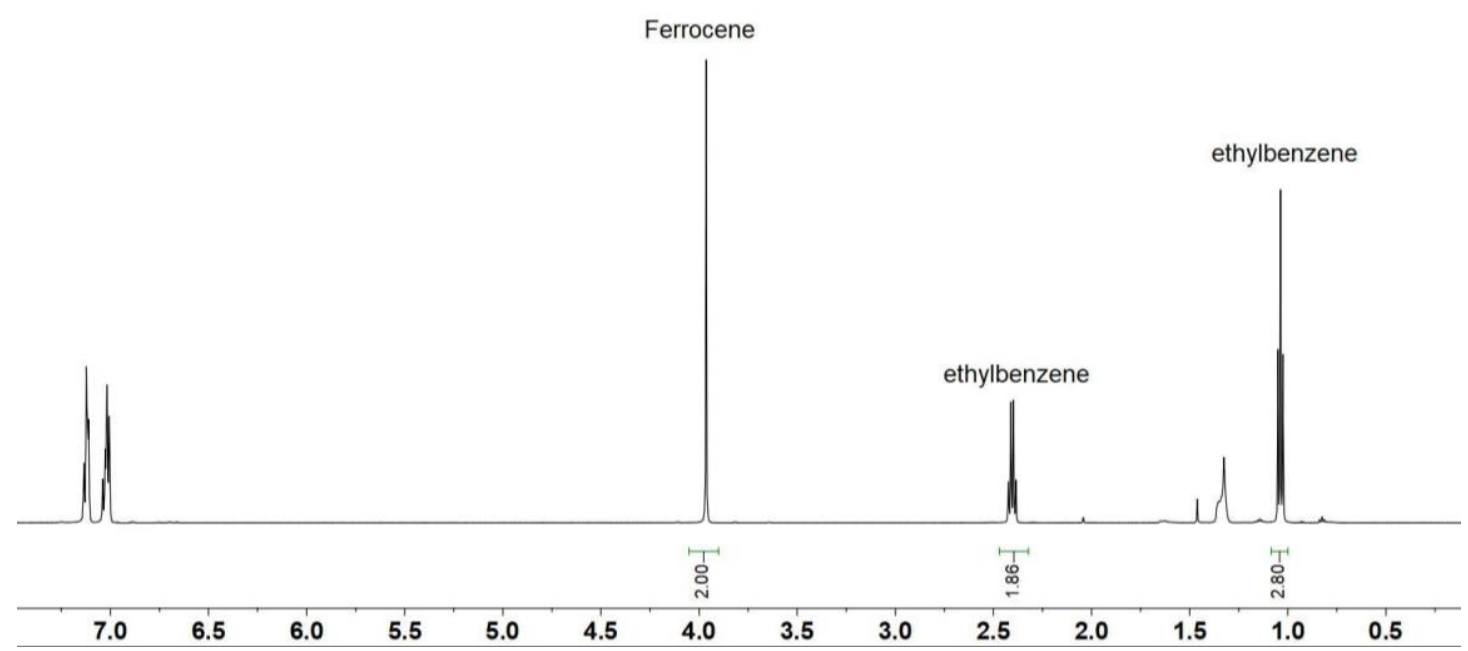

Figure S95. ${ }^{1} \mathrm{H}$ NMR (600 MHz, $\left.\mathrm{C}_{6} \mathrm{D}_{6}, 299 \mathrm{~K}\right)$ spectra of the obtained reaction mixture.

Experiment 6: Hydrogenation of cyclohexene in the presence of the Ir complex 18a.

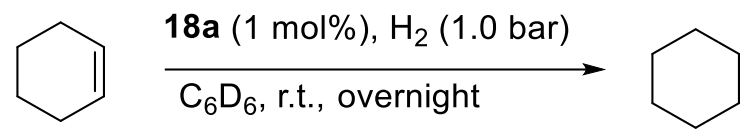

Scheme S23.

Following the general procedure, the conversion to cyclohexane was $117 \%$ (overlapping with $\left.\mathrm{C}_{6} \mathrm{H}_{6} \mathrm{D}_{6}\right)$ based on ${ }^{1} \mathrm{H}$ NMR relative to ferrocene.

[Comment: After the reaction, metal precipitate was observed.]

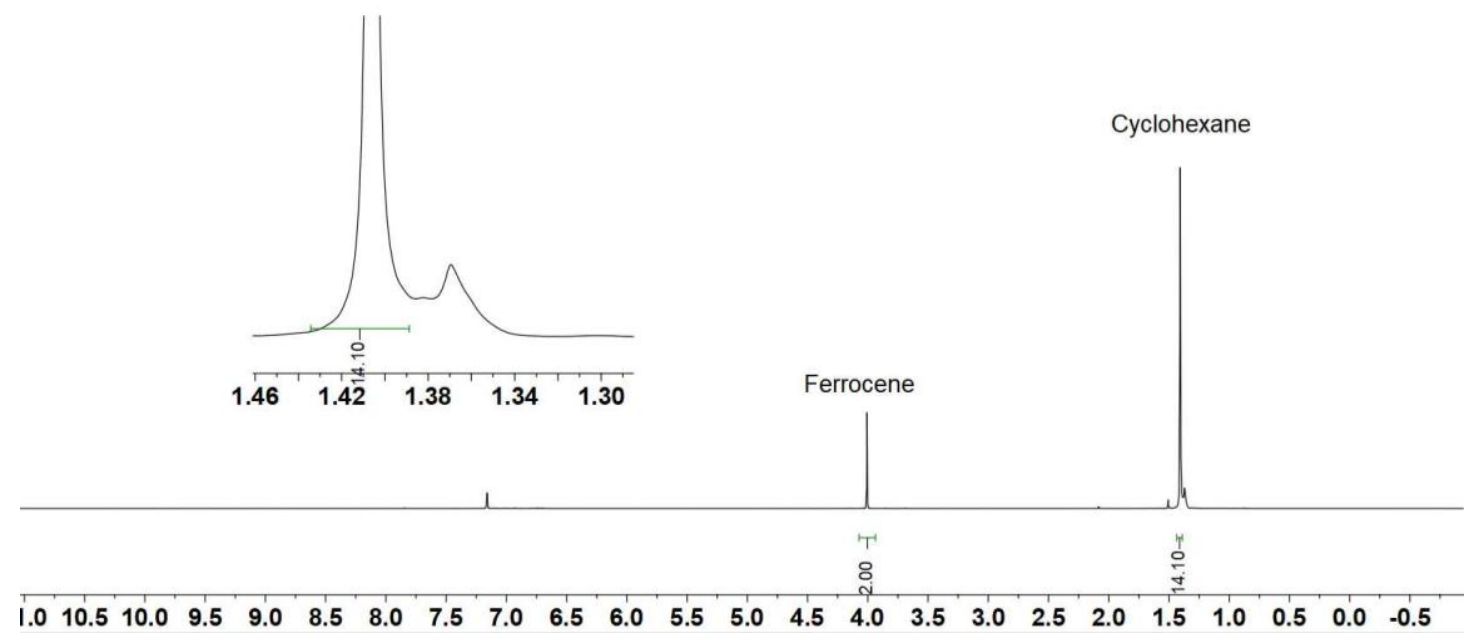

Figure S96. ${ }^{1} \mathrm{H}$ NMR (600 MHz, $\left.\mathrm{C}_{6} \mathrm{D}_{6}, 299 \mathrm{~K}\right)$ spectra of the obtained reaction mixture.

Experiment 7: Hydrogenation of chalcone in the presence of the Ir complex 18a.

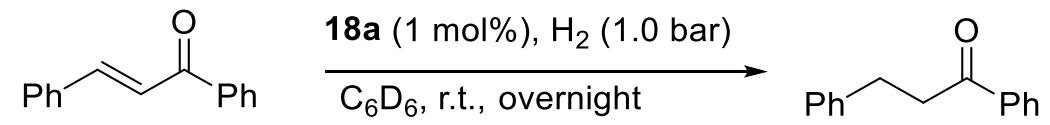

Scheme S24. 
Following the general procedure, the conversion to 1,3-diphenylpropan-1-one was $90 \%$ based on ${ }^{1} \mathrm{H}$ NMR relative to ferrocene.

[Comment: After the reaction, metal precipitate was observed.]

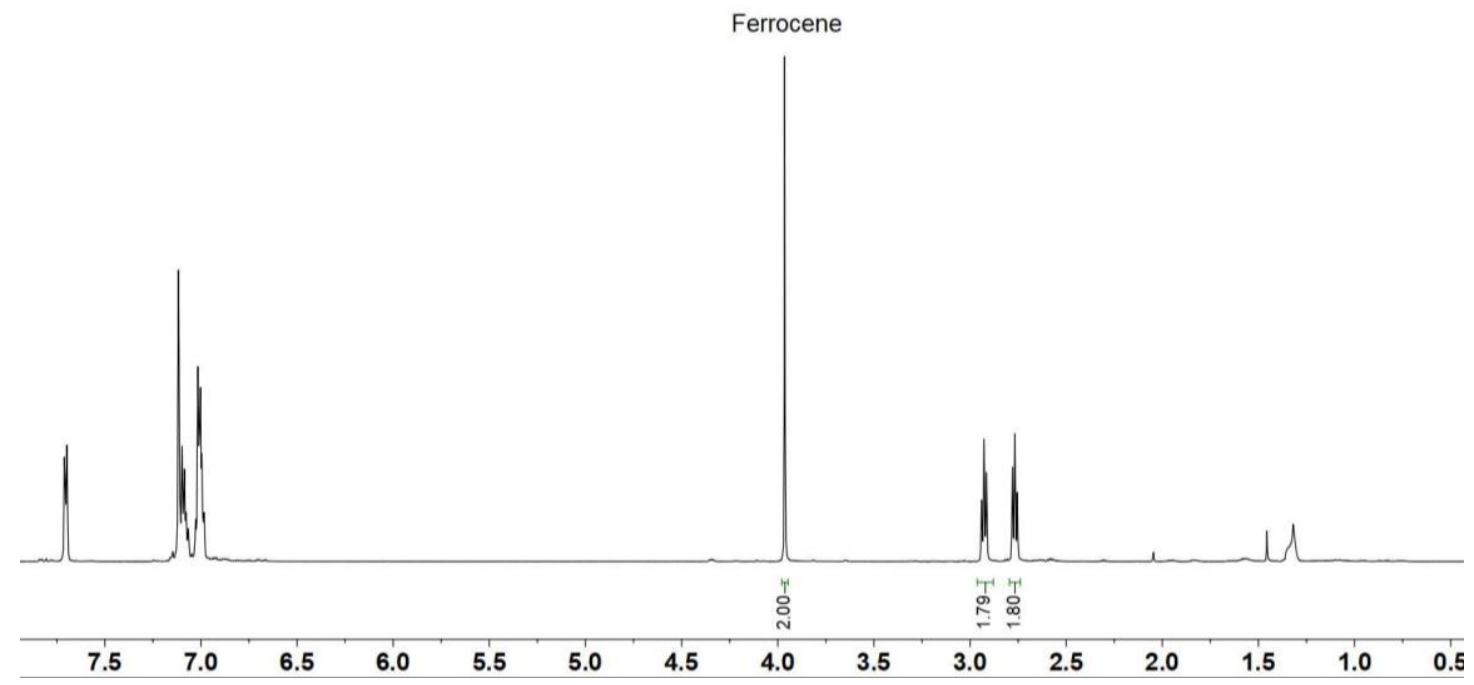

Figure S97. ${ }^{1} \mathrm{H}$ NMR $\left(600 \mathrm{MHz}, \mathrm{C}_{6} \mathrm{D}_{6}, 299 \mathrm{~K}\right)$ spectra of the obtained reaction mixture.

Experiment 8: Hydrogenation of 1-hexene in the presence of the Ir complex 18a.

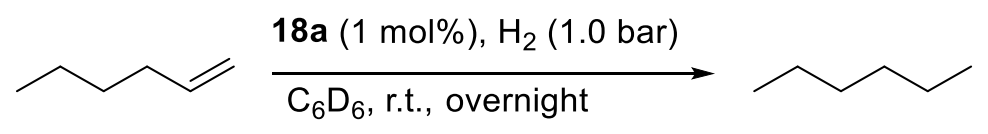

\section{Scheme S25.}

Following the general procedure, the conversion to $n$-hexane was $22 \%$ based on ${ }^{1} \mathrm{H}$ NMR relative to ferrocene.

[Comment: After the reaction, metal precipitate was observed.]

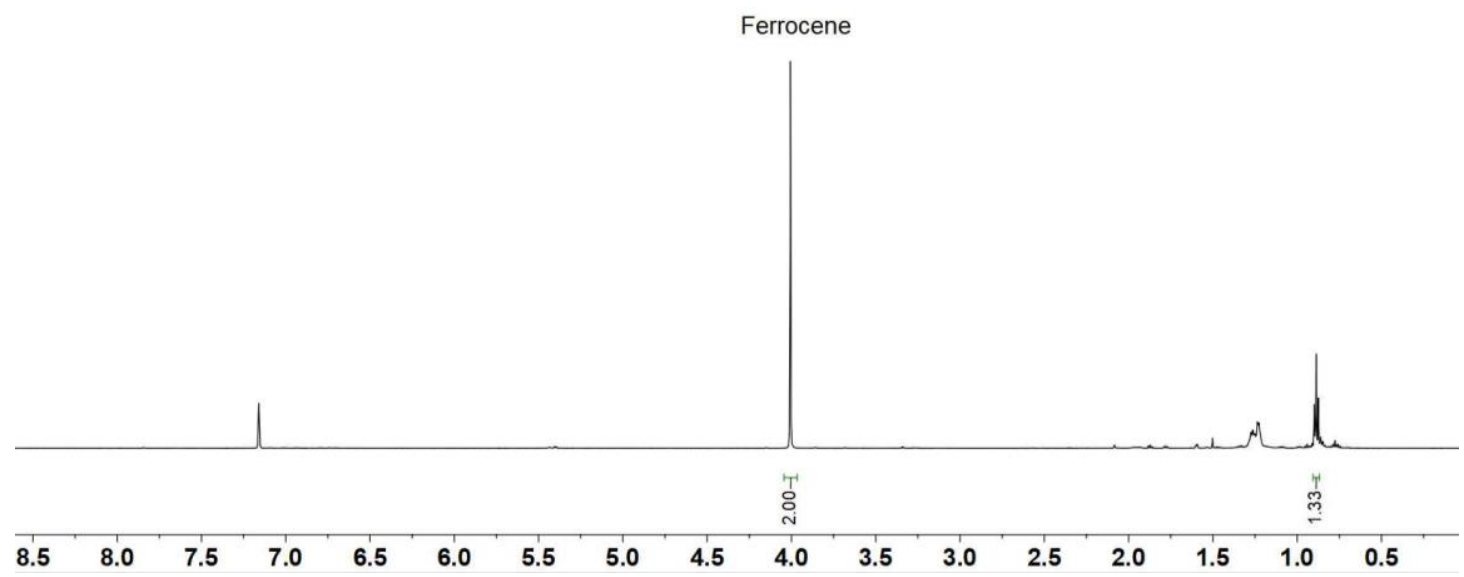

Figure S98. ${ }^{1} \mathrm{H}$ NMR (600 MHz, $\left.\mathrm{C}_{6} \mathrm{D}_{6}, 299 \mathrm{~K}\right)$ spectra of the obtained reaction mixture. 
Experiment 9: Hydrogenation of 1,2-diphenylactylene in the presence of the Rh complex 18b.

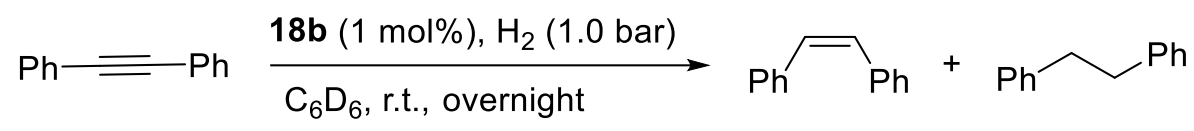

\section{Scheme S26.}

Following the general procedure, the conversion to stilbene and 1,2-diphenylethane were $27 \%$ and $8 \%$ based on ${ }^{1} \mathrm{H}$ NMR relative to ferrocene, respectively.

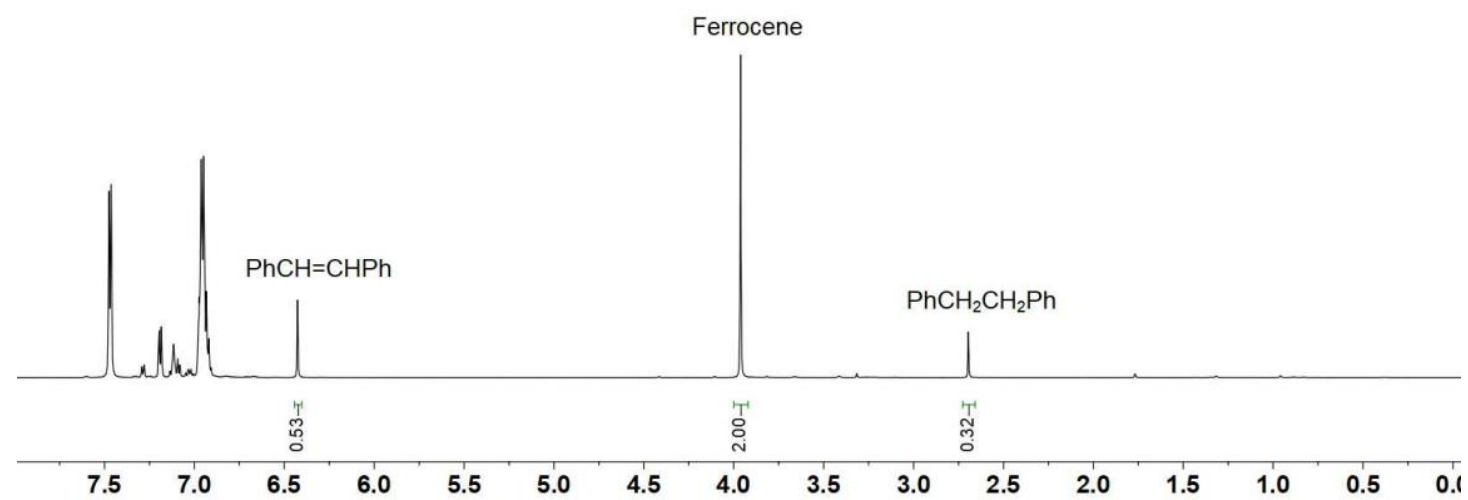

Figure S99. ${ }^{1} \mathrm{H}$ NMR (600 MHz, $\mathrm{C}_{6} \mathrm{D}_{6}, 299 \mathrm{~K}$ ) spectra of the obtained reaction mixture.

Experiment 10: Hydrogenation of styrene in the presence of the Rh complex 18b.

$$
\frac{\mathbf{1 8 b}(1 \mathrm{~mol} \%), \mathrm{H}_{2}(1.0 \mathrm{bar})}{\mathrm{C}_{6} \mathrm{D}_{6}, \text { r.t., overnight }}
$$

Scheme S27.

Following the general procedure, the conversion to ethylbenzene was quantitative based on ${ }^{1} \mathrm{H}$ NMR relative to ferrocene.

[Comment: After the reaction, a metal precipitate was observed.]

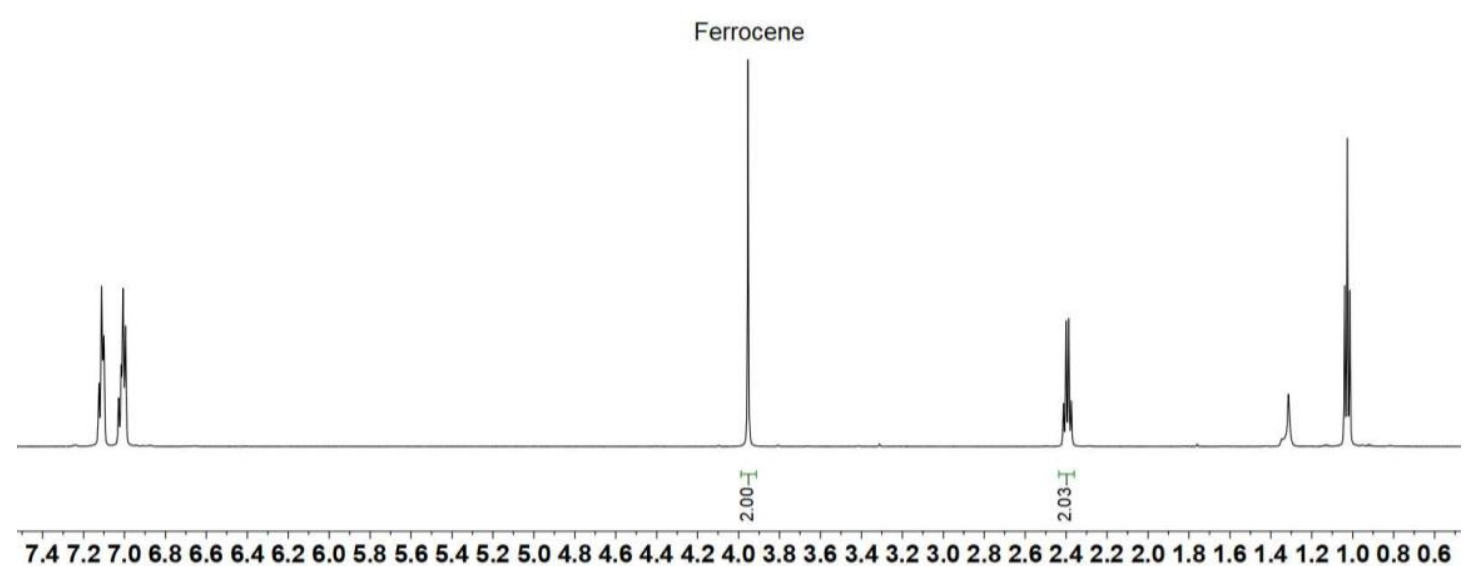

Figure S100. ${ }^{1} \mathrm{H}$ NMR $\left(600 \mathrm{MHz}, \mathrm{C}_{6} \mathrm{D}_{6}, 299 \mathrm{~K}\right)$ spectra of the obtained reaction mixture. 
Experiment 11: Hydrogenation of cyclohexene in the presence of the Rh complex 18b.

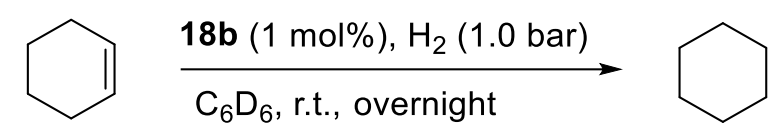

\section{Scheme S28.}

Following the general procedure, the conversion to cyclohexane was quantitative based on ${ }^{1} \mathrm{H}$ NMR relative to ferrocene.

[Comment: After the reaction, metal precipitate was observed.]

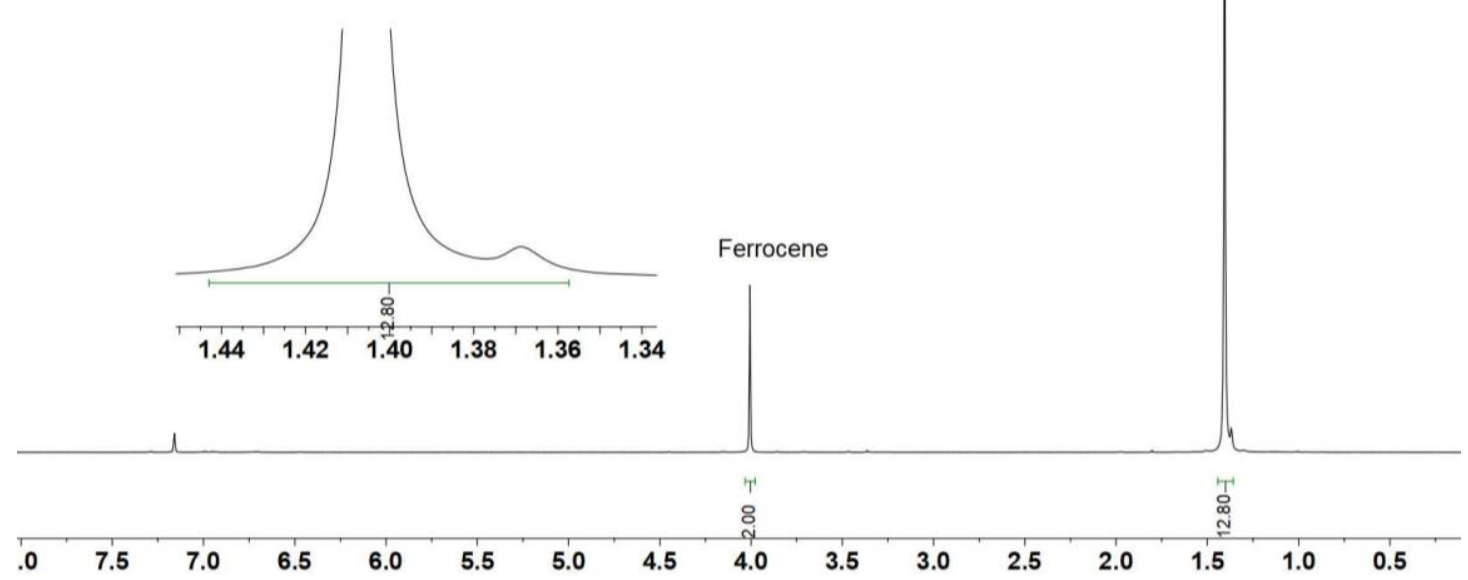

Figure S101. ${ }^{1} \mathrm{H}$ NMR $\left(600 \mathrm{MHz}, \mathrm{C}_{6} \mathrm{D}_{6}, 299 \mathrm{~K}\right)$ spectra of the obtained reaction mixture.

Comparative experiment 1: Hydrogenation of cyclohexene in the presence of the Cplr(cod).

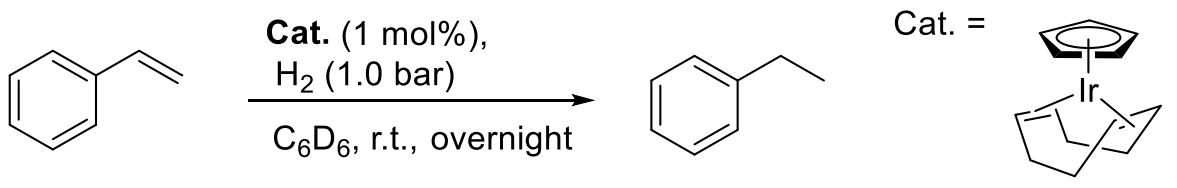

Scheme S29.

Following the general procedure, $\mathrm{Cplr}(\operatorname{cod})$ was used as the catalyst instead. No conversion was observed. 


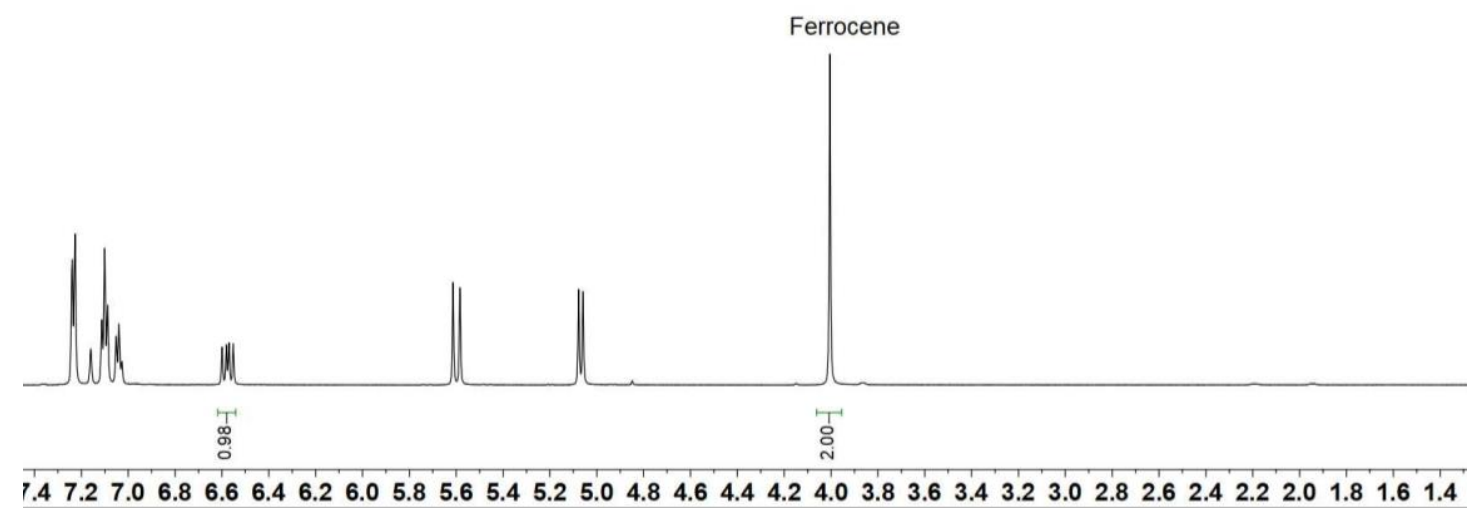

Figure S102. ${ }^{1} \mathrm{H}$ NMR ( $\left.600 \mathrm{MHz}, \mathrm{C}_{6} \mathrm{D}_{6}, 299 \mathrm{~K}\right)$ spectra of the obtained reaction mixture.

Comparative experiment 2: Hydrogenation of cyclohexene in the presence of the $\mathrm{CpRh}(\mathrm{nbd})$.<smiles>C=Cc1ccccc1</smiles>

Cat. (1 mol\%),

$$
\underset{\mathrm{C}_{6} \mathrm{D}_{6} \text {, r.t., overnight }}{\stackrel{\mathrm{H}_{2}(1.0 \text { bar })}{\longrightarrow}}
$$<smiles>CCc1ccccc1</smiles>

Cat. $=$

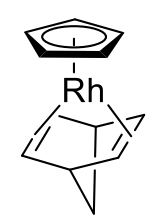

Scheme S30.

Following the general procedure, $\mathrm{CpRh}(\mathrm{nbd})$ was used as the catalyst instead. No conversion was observed.

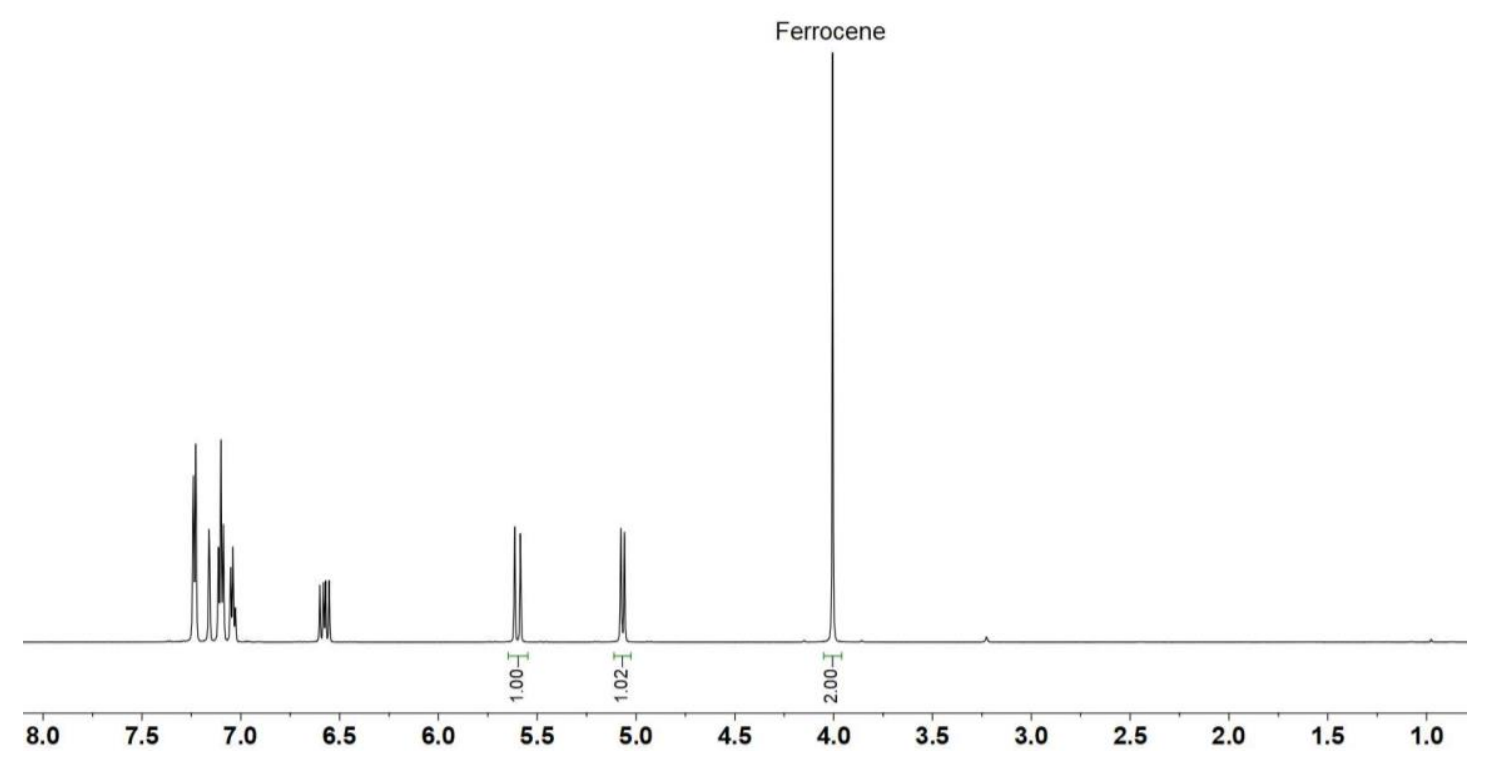

Figure S103. ${ }^{1} \mathrm{H}$ NMR (600 MHz, $\left.\mathrm{C}_{6} \mathrm{D}_{6}, 299 \mathrm{~K}\right)$ spectra of the obtained reaction mixture. 
Mercury test with compound 18a

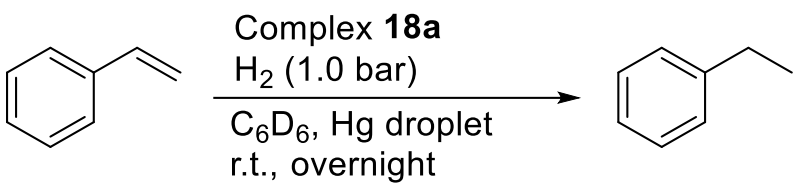

Scheme S31.

In a glovebox with an argon atmosphere, a mixture of compound $18 \mathrm{a}(4.5 \mathrm{mg}, 0.005 \mathrm{mmol}, 1 \mathrm{~mol} \%)$ and styrene $(52 \mathrm{mg}, 0.5 \mathrm{mmol})$ was dissolved in $\mathrm{C}_{6} \mathrm{D}_{6}(1.0 \mathrm{~mL})$. Then the obtained solution was transferred to a Schlenk tube. Then drops of $\mathrm{Hg}$ were added to the resulting mixture which was stirred vigorously for $30 \mathrm{~min}$ under argon atmosphere. After the mixture was degassed, it was stirred overnight at room temperature in a $\mathrm{H}_{2}$ atmosphere ( 1.0 bar). A black metal precipitation was observed on the inside wall of the tube. Ferrocene ( $18.6 \mathrm{mg}, 0.1 \mathrm{mmol}, 0.2$ equiv.) was added as internal standard. The obtained reaction mixture was characterized by ${ }^{1} \mathrm{H}$ NMR experiments: styrene was fully consumed and the conversion to ethylbenzene is determined by the integration relative to ferrocene (94\%).

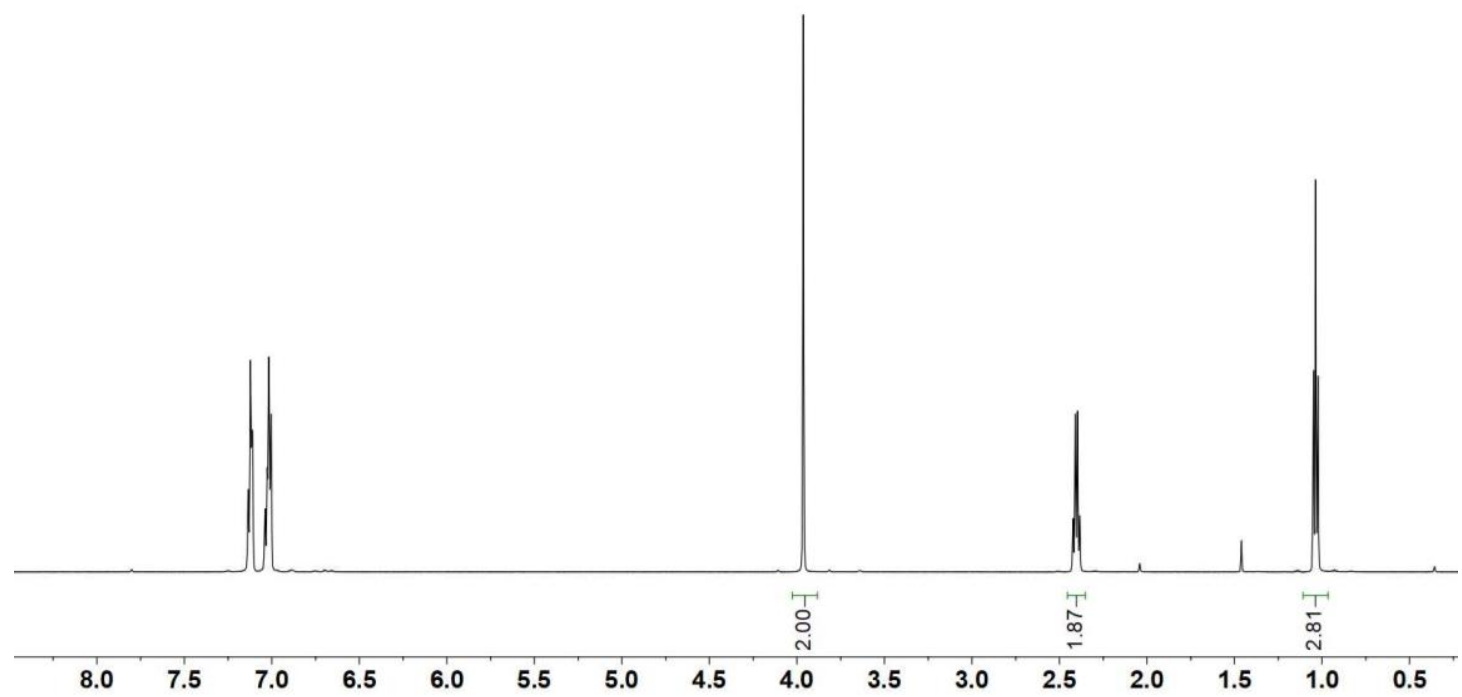

Figure S104. ${ }^{1} \mathrm{H}$ NMR (600 MHz, $\left.\mathrm{C}_{6} \mathrm{D}_{6}, 299 \mathrm{~K}\right)$ spectrum of the obtained mixture. 


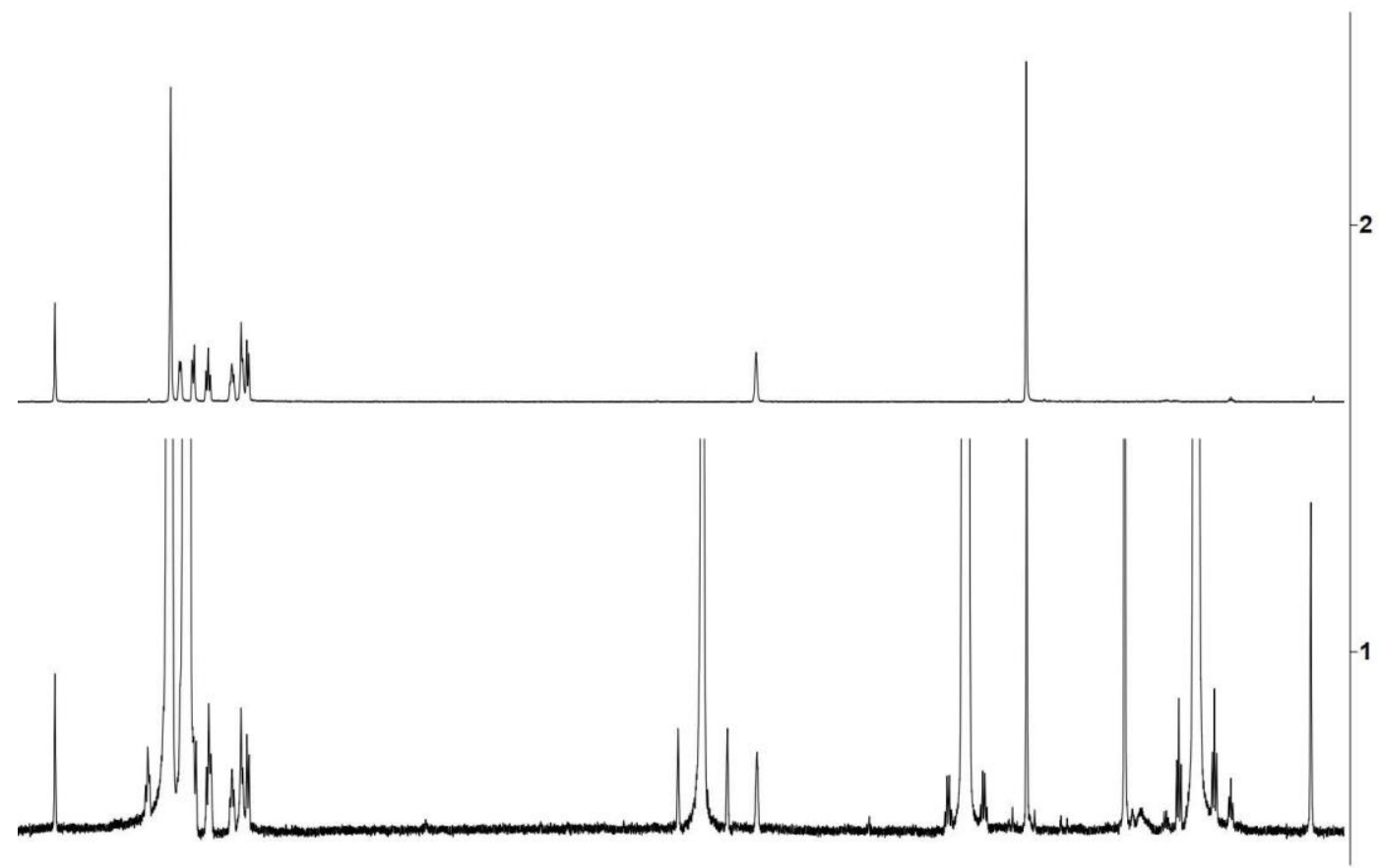

\begin{tabular}{lllllllllllllllll}
\hline .0 & 7.5 & 7.0 & 6.5 & 6.0 & 5.5 & 5.0 & 4.5 & 4.0 & 3.5 & 3.0 & 2.5 & 2.0 & 1.5 & 1.0 & 0.5
\end{tabular}

Figure S105. ${ }^{1} \mathrm{H}$ NMR (600 MHz, $\mathrm{C}_{6} \mathrm{D}_{6}, 299 \mathrm{~K}$ ) spectra of (1) the obtained mixture; (2) compound $16 a$.

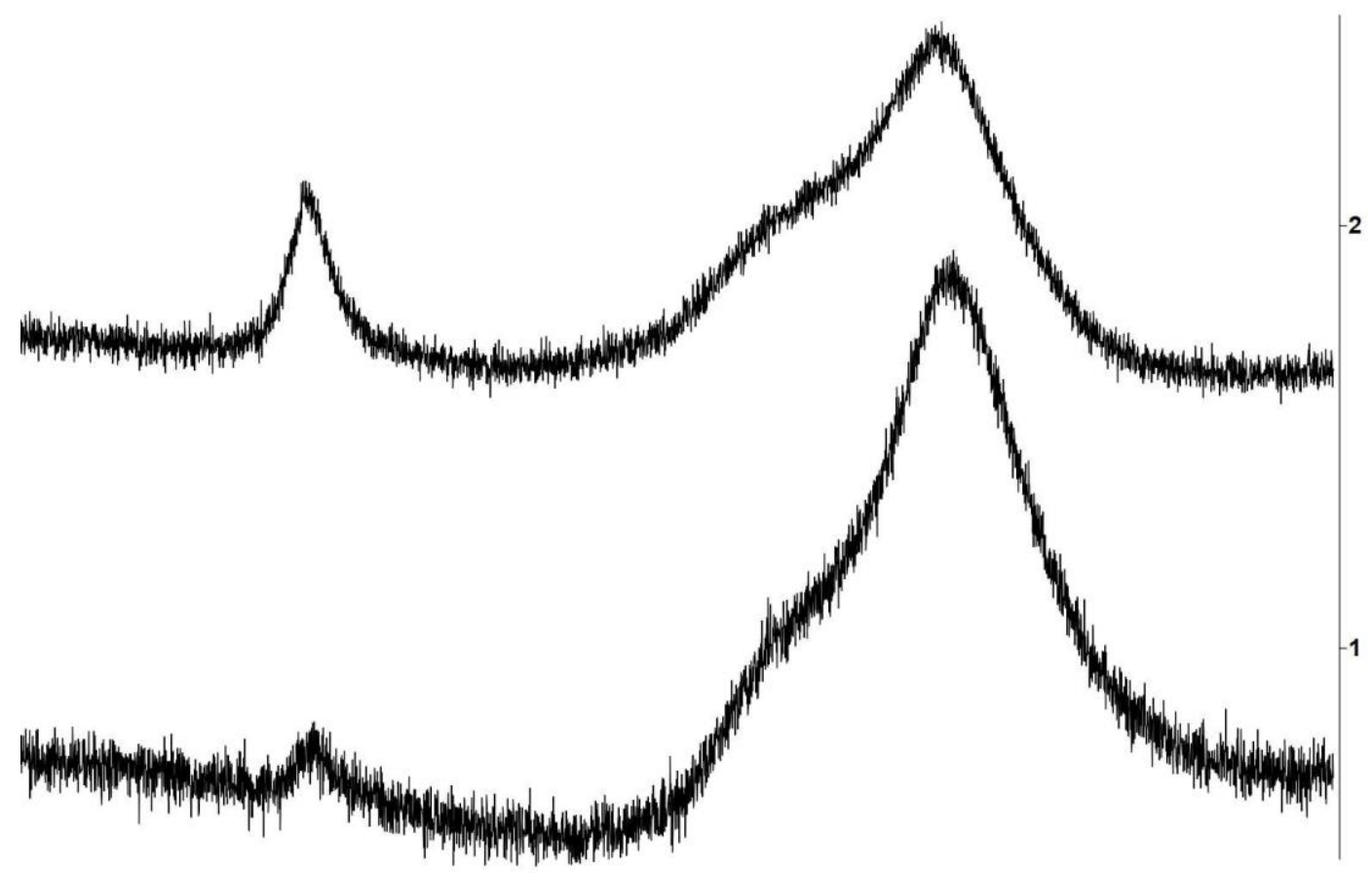

$\begin{array}{lllllllllllllllllllllllllllllllllllllllllll}85 & 80 & 75 & 70 & 65 & 60 & 55 & 50 & 45 & 40 & 35 & 30 & 25 & 20 & 15 & 10 & 5 & 0 & -5 & -10 & -15 & -20 & -25 & -30 & -35 & -40\end{array}$

Figure S106. ${ }^{11} \mathrm{~B}\left\{{ }^{1} \mathrm{H}\right\} \mathrm{NMR}\left(192 \mathrm{MHz}, \mathrm{C}_{6} \mathrm{D}_{6}, 299 \mathrm{~K}\right)$ spectra of (1) the obtained mixture;(2) compound $16 \mathrm{a}$ 


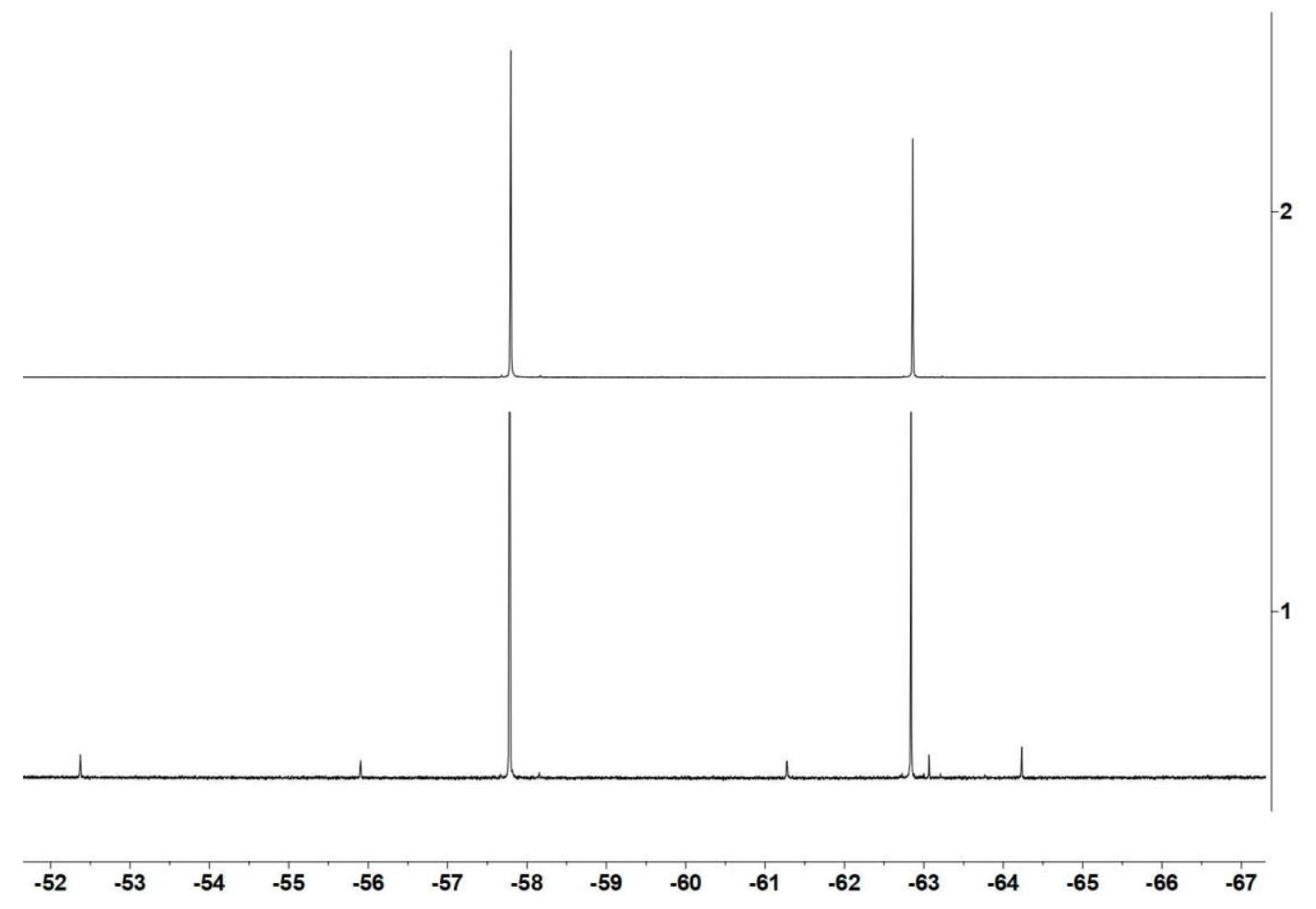

Figure S107. ${ }^{19} \mathrm{~F}$ NMR (564 MHz, $\mathrm{C}_{6} \mathrm{D}_{6}, 299 \mathrm{~K}$ ) spectra of (1) the obtained mixture; (2) compound $16 a$.

\section{Mercury test with compound 18b}

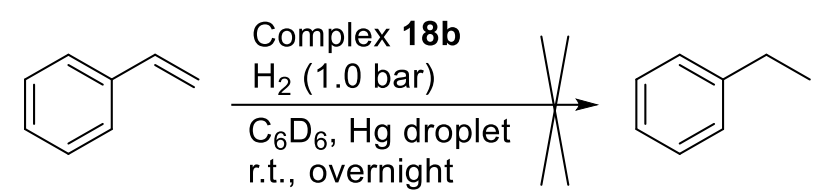

Scheme S32.

In a glovebox with an argon atmosphere, a mixture of compound $\mathbf{1 8 b}(4.0 \mathrm{mg}, 0.005 \mathrm{mmol}, 1 \mathrm{~mol} \%)$ and styrene $(52 \mathrm{mg}, 0.5 \mathrm{mmol})$ was dissolved in $\mathrm{C}_{6} \mathrm{D}_{6}(1.0 \mathrm{~mL})$. Then the obtained solution was transferred to a Schlenk tube. Then drops of $\mathrm{Hg}$ were added to the resulting mixture which was stirred vigorously for $30 \mathrm{~min}$ under argon atmosphere. After the mixture was degassed, it was stirred overnight at room temperature in a $\mathrm{H}_{2}$ atmosphere ( $1.0 \mathrm{bar}$ ). Ferrocene $(18.6 \mathrm{mg}, 0.1 \mathrm{mmol}$, 0.2 equiv.) was added as internal standard. The obtained reaction mixture was characterized by ${ }^{1} \mathrm{H}$ NMR experiments: The sample contained unreacted styrene (92\%) and trace amount (ca. $0.5 \%$ ) of ethylbenzene. 


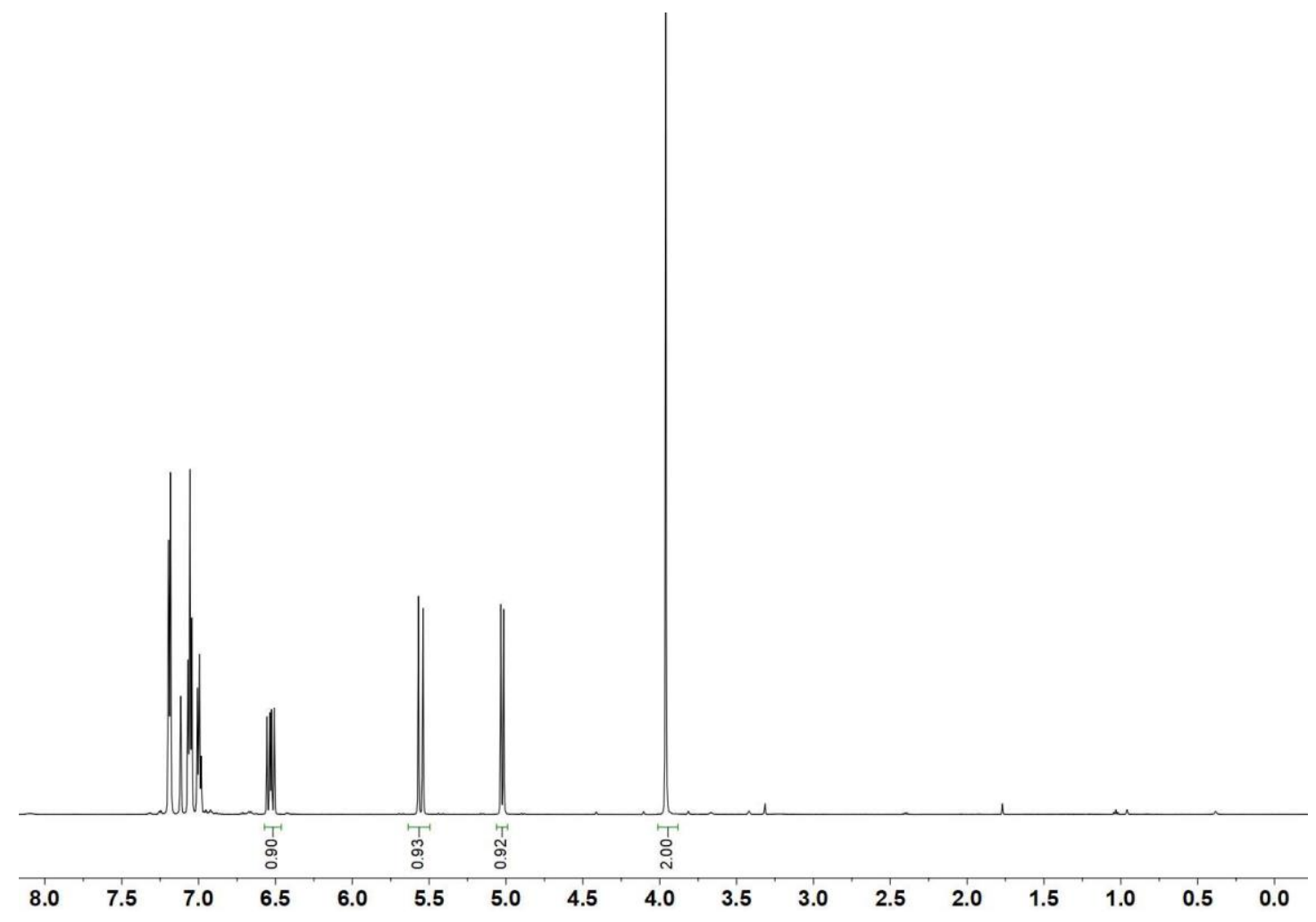

Figure S108. ${ }^{1} \mathrm{H}$ NMR $\left(600 \mathrm{MHz}, \mathrm{C}_{6} \mathrm{D}_{6}, 299 \mathrm{~K}\right)$ spectrum of the obtained mixture.

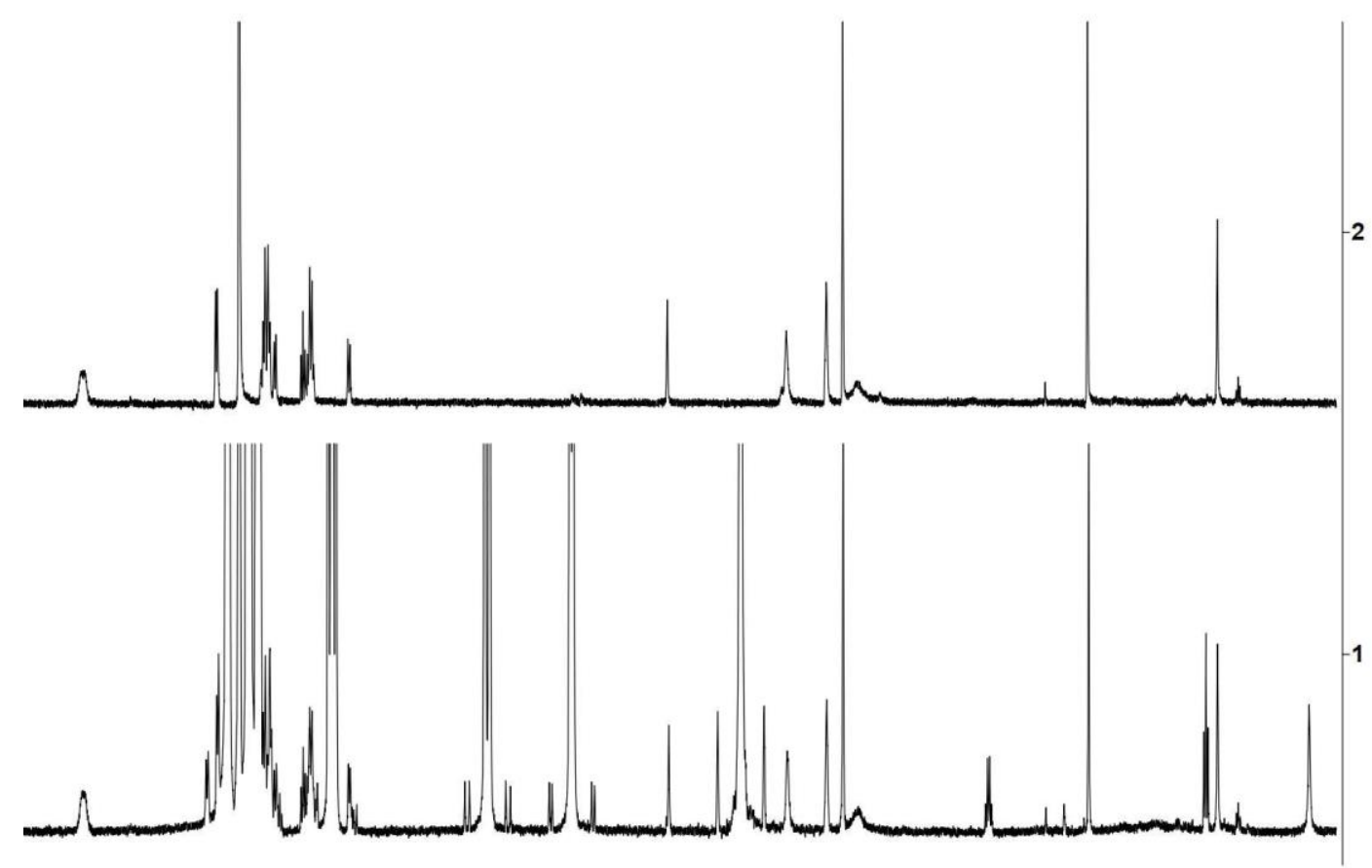

$\begin{array}{llllllllllllllll}8.0 & 7.5 & 7.0 & 6.5 & 6.0 & 5.5 & 5.0 & 4.5 & 4.0 & 3.5 & 3.0 & 2.5 & 2.0 & 1.5 & 1.0 & 0.5\end{array}$

Figure S109. ${ }^{1} \mathrm{H}$ NMR (600 MHz, $\mathrm{C}_{6} \mathrm{D}_{6}, 299 \mathrm{~K}$ ) spectra of (1) the obtained mixture; (2) compound $18 b$. 


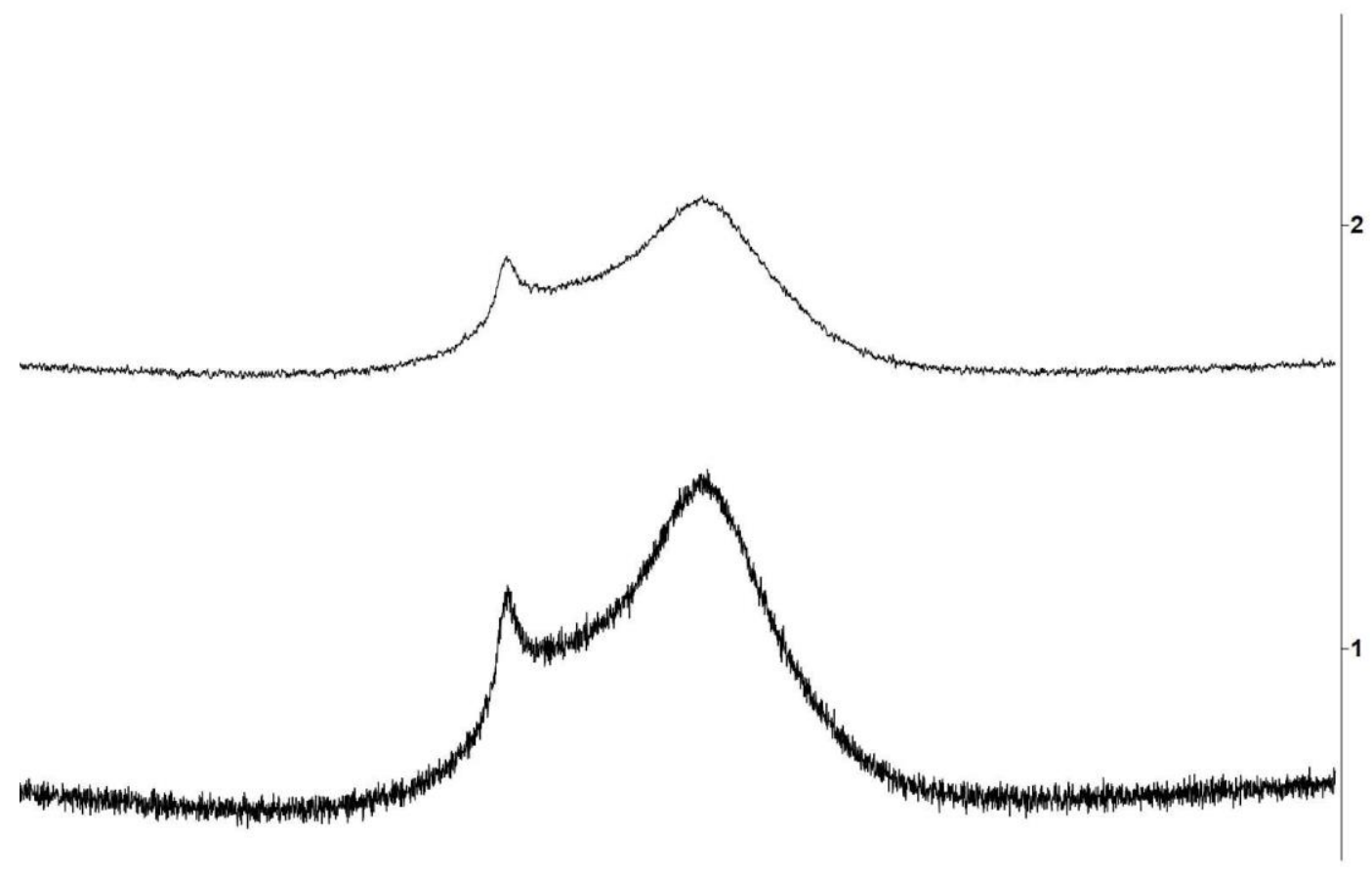

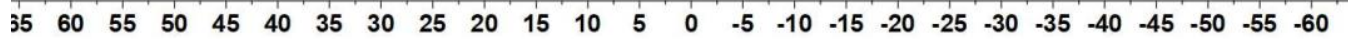

Figure S110. ${ }^{11} \mathrm{~B}\left\{{ }^{1} \mathrm{H}\right\}$ NMR (192 MHz, $\left.\mathrm{C}_{6} \mathrm{D}_{6}, 299 \mathrm{~K}\right)$ spectra of (1) the obtained mixture; (2) compound $\mathbf{1 8 b}$.

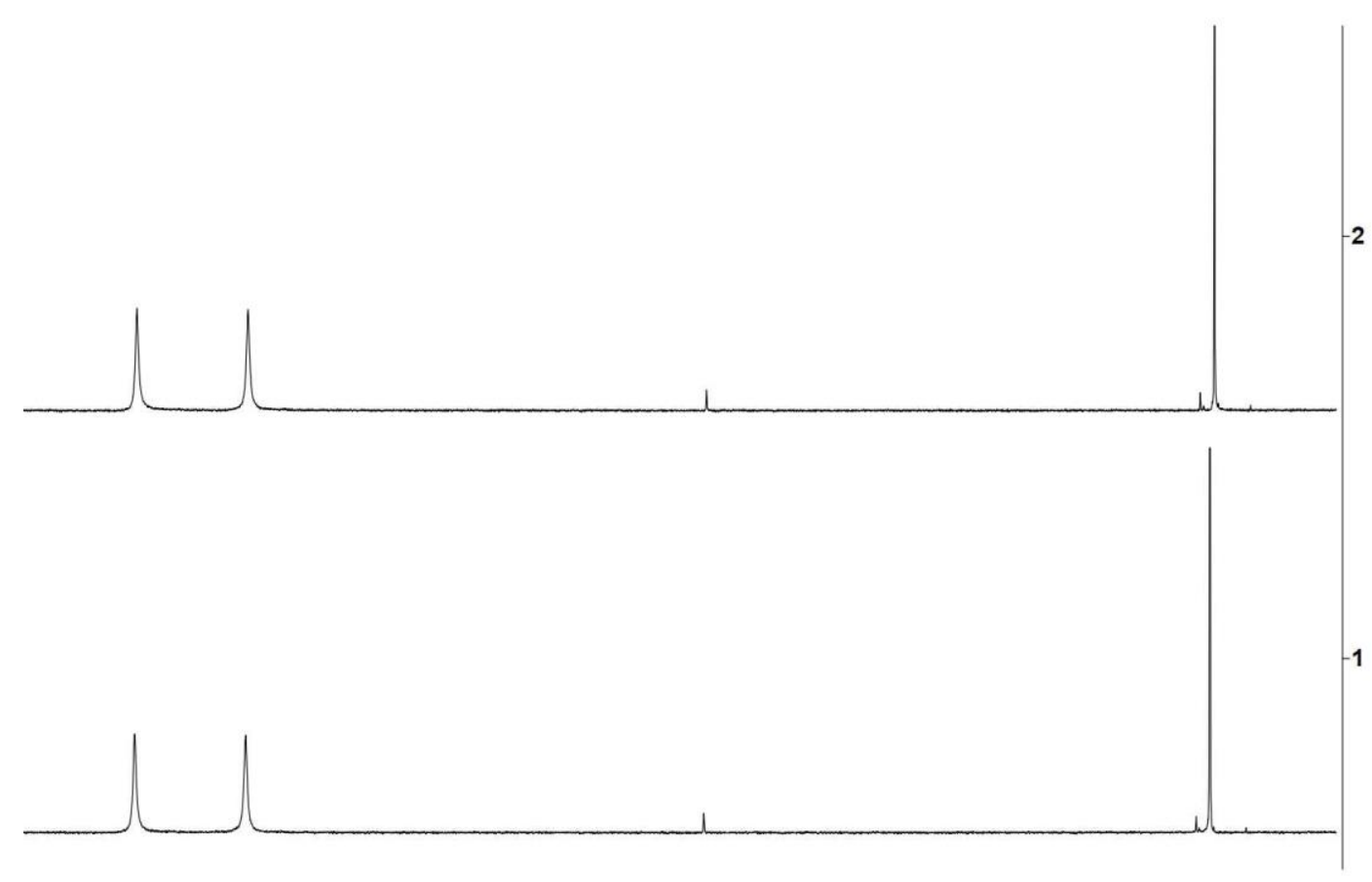

\begin{tabular}{lllllllllllllll}
\hline 51.0 & -52.0 & -53.0 & -54.0 & -55.0 & -56.0 & -57.0 & -58.0 & -59.0 & -60.0 & -61.0 & -62.0 & -63.0 & -64.0
\end{tabular}

Figure S111. ${ }^{19} \mathrm{~F}$ NMR (564 MHz, $\mathrm{C}_{6} \mathrm{D}_{6}, 299 \mathrm{~K}$ ) spectra of (1) the obtained mixture; (2) compound $18 \mathrm{~b}$. 


\section{Preparation of the azaborinine derivative 24a}

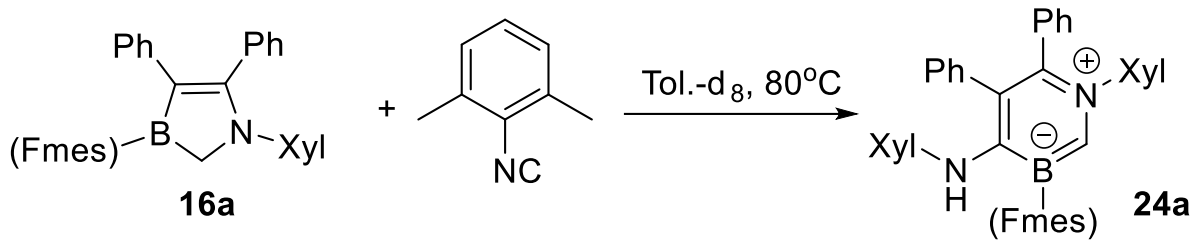

\section{Scheme S33.}

At room temperature, the azaborole $16 \mathrm{a}(60.3 \mathrm{mg}, 0.1 \mathrm{mmol}, 1 \mathrm{eq}$.) was added to a solution of 2,6dimethylphenyl isocyanide $\left(13.1 \mathrm{mg}, 0.1 \mathrm{mmol}, 1\right.$ eq.) in $\mathrm{d}_{8}$-toluene $(1 \mathrm{~mL})$ under an argon atmosphere in a J. Young tube. The resulting solution was stored at $80^{\circ} \mathrm{C}$ for 14 days. Then all volatiles were removed in vacuo and the residue was dissolved in pentane $(1 \mathrm{~mL})$ and stored at $35^{\circ} \mathrm{C}$ finally to give the compound $24 \mathrm{a}$ as a yellow solid ( $57 \mathrm{mg}, 78 \%$ yield).

HRMS for $\mathrm{C}_{41} \mathrm{H}_{32} \mathrm{BN}_{2} \mathrm{~F}_{9}{ }^{+}[\mathrm{M}]^{+}$: calc. 734.2516; found: 734.2536 .

${ }^{1} \mathrm{H}$ NMR $\left(600 \mathrm{MHz}\right.$, methylene chloride- $\left.d_{2}, 299 \mathrm{~K}\right): \delta=7.87\left(\mathrm{~s}, 2 \mathrm{H}, m\right.$-Fmes), $7.08\left(\mathrm{~m}, 2 \mathrm{H}, o-\mathrm{Ph}^{(5)}\right)$, $7.01\left(\mathrm{~m}, 2 \mathrm{H}, m-\mathrm{Ph}^{(5)}\right), 6.97\left(\mathrm{~m}, 3 \mathrm{H}, o-\mathrm{Ph}^{(6)}, p-\mathrm{Xyl}{ }^{(1)}\right), 6.93\left(\mathrm{t},{ }^{3} \mathrm{JHH}_{\mathrm{H}}=7.8 \mathrm{~Hz}, 1 \mathrm{H}, p-\mathrm{Ph}^{(5)}\right), 6.90(\mathrm{~m}, 3 \mathrm{H}$, $p$ - $\left.\mathrm{Ph}^{(6)}, m-\mathrm{Xy}^{(1)}\right), 6.87\left(\mathrm{~m}, 2 \mathrm{H}, m-\mathrm{Ph}^{(6)}\right), 6.68(\mathrm{~s}, 1 \mathrm{H}, \mathrm{C}(2) \mathrm{H}), 6.61\left(\mathrm{t},{ }^{3} \mathrm{JHH}_{\mathrm{HH}}=7.3 \mathrm{~Hz}, 1 \mathrm{H}, p-\mathrm{Xy}^{(4)}\right), 6.54$ $\left(\mathrm{d},{ }^{3} \mathrm{~J}_{\mathrm{HH}}=7.3 \mathrm{~Hz}, 2 \mathrm{H}, m-\left.\mathrm{Xy}\right|^{(4)}\right), 5.38(\mathrm{~s}, 1 \mathrm{H}, \mathrm{NH}), 2.15\left(\mathrm{~s}, 6 \mathrm{H}, \mathrm{o}-\mathrm{CH}_{3}{ }^{\mathrm{Xy}(1)}\right), 2.02\left(\mathrm{~s}, 6 \mathrm{H}, \mathrm{o}-\mathrm{CH}_{3}{ }^{\mathrm{Xy}((4))}\right)$.

${ }^{13} \mathrm{C}\left\{{ }^{1} \mathrm{H}\right\}$ NMR (151 MHz, methylene chloride- $d_{2}, 299 \mathrm{~K}$ ): $\delta=162.9$ (br, C(4)), 149.0 (br, i-Fmes), 146.2 $\left(i-\mathrm{Xyl}^{(1)}\right), 140.2\left(i-\mathrm{Xyl}^{(4)}\right), 138.6(\mathrm{C}(6)), 138.3\left(i-\mathrm{Ph}^{(5)}\right), 138.1(\mathrm{br}, \mathrm{C}(2) \mathrm{H}), 136.6\left(i-\mathrm{Ph}^{(6)}, \mathrm{o}-\left.\mathrm{Xy}\right|^{(4)}\right), 135.6$ $\left(q,{ }^{2} \mathrm{JFC}_{\mathrm{FC}}=29.1 \mathrm{~Hz}, o-\mathrm{Fmes}\right), 134.2\left(o-\left.\mathrm{Xy}\right|^{(1)}\right), 131.8\left(o-\mathrm{Ph}^{(5)}\right), 130.4\left(o-\mathrm{Ph}^{(6)}\right), 129.1\left(q,{ }^{2} \mathrm{JFC}_{\mathrm{FC}}=33.6 \mathrm{~Hz}, p-\right.$ Fmes), $128.2\left(m-\mathrm{Ph}^{(5)}\right), 128.1\left(m-\mathrm{Xy}^{(1)}\right), 128.0\left(p-\mathrm{Xy}^{(1)}\right), 127.9\left(m-\mathrm{Xy}^{(4)}\right), 127.4\left(p-\mathrm{Ph}^{(6)}\right), 127.03(\mathrm{br}$, $C(5)), 126.95\left(m-\mathrm{Ph}^{(6)}\right), 126.7\left(p-\mathrm{Ph}^{(5)}\right), 126.0\left(p-\mathrm{Xy}^{(4)}\right), 124.9\left(m\right.$-Fmes), $124.4\left(\mathrm{q}^{(1}{ }^{1} \mathrm{FC}=275.4 \mathrm{~Hz}, 0\right.$ $\left.\mathrm{CF}_{3}\right), 124.4\left(\mathrm{q},{ }^{1} \mathrm{JFC}_{\mathrm{FC}}=275.4 \mathrm{~Hz}, o-\mathrm{CF}_{3}\right), 123.9\left(\mathrm{q},{ }^{1} \mathrm{~J}_{\mathrm{FC}}=271.7 \mathrm{~Hz}, p-\mathrm{CF}_{3}\right), 18.8\left(\mathrm{q}, \mathrm{J}=2.8 \mathrm{~Hz}, o-\mathrm{CH}_{3} \mathrm{Xy}(4)\right.$ ), $17.8\left(0-\mathrm{CH}_{3}{ }^{\mathrm{XY}(1)}\right)$.

${ }^{11} \mathrm{~B}\left\{{ }^{1} \mathrm{H}\right\}$ NMR $\left(192 \mathrm{MHz}\right.$, methylene chloride- $\left.d_{2}, 299 \mathrm{~K}\right): \delta=26.2\left(\mathrm{v}_{1 / 2} \approx 350 \mathrm{~Hz}\right)$.

${ }^{19} \mathrm{~F}$ NMR $\left(564 \mathrm{MHz}\right.$, methylene chloride- $\left.d_{2}, 299 \mathrm{~K}\right): \delta=-57.1\left(\mathrm{br}, 2 \mathrm{~F}, o-\mathrm{CF}_{3}\right),-63.5\left(\mathrm{~s}, 1 \mathrm{~F}, p-\mathrm{CF}_{3}\right)$.

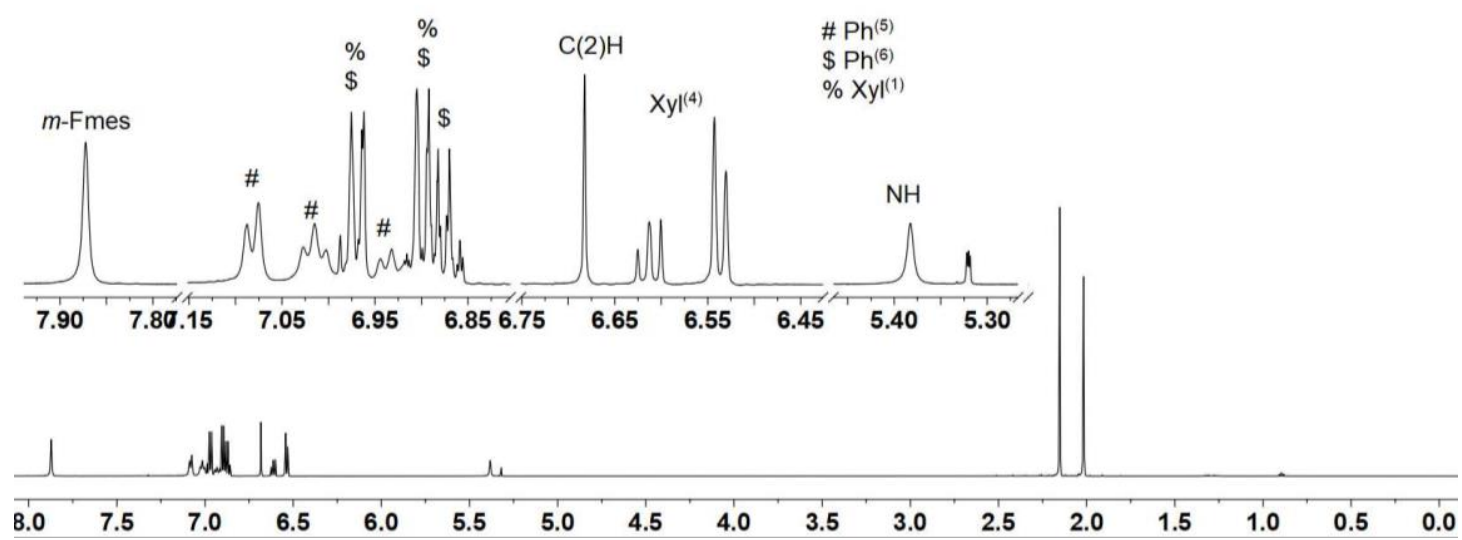

Figure S112. ${ }^{1} \mathrm{H}$ NMR $\left(600 \mathrm{MHz}\right.$, methylene chloride- $\left.d_{2}, 299 \mathrm{~K}\right)$ spectrum of compound $24 \mathrm{a}$. 

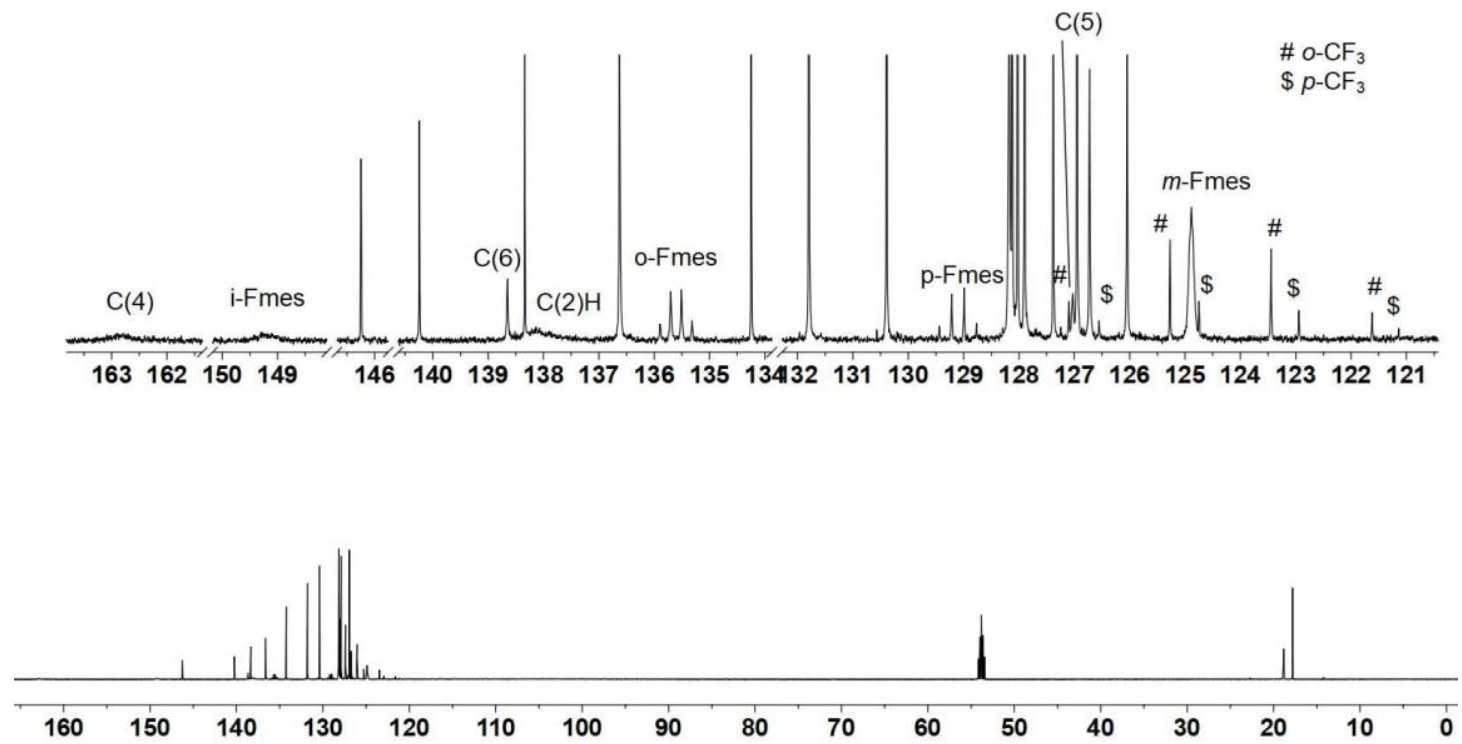

Figure S113. ${ }^{13} \mathrm{C}\left\{{ }^{1} \mathrm{H}\right\} \mathrm{NMR}\left(151 \mathrm{MHz}\right.$, methylene chloride- $\mathrm{d}_{2}, 299 \mathrm{~K}$ ) spectrum of compound 24a.

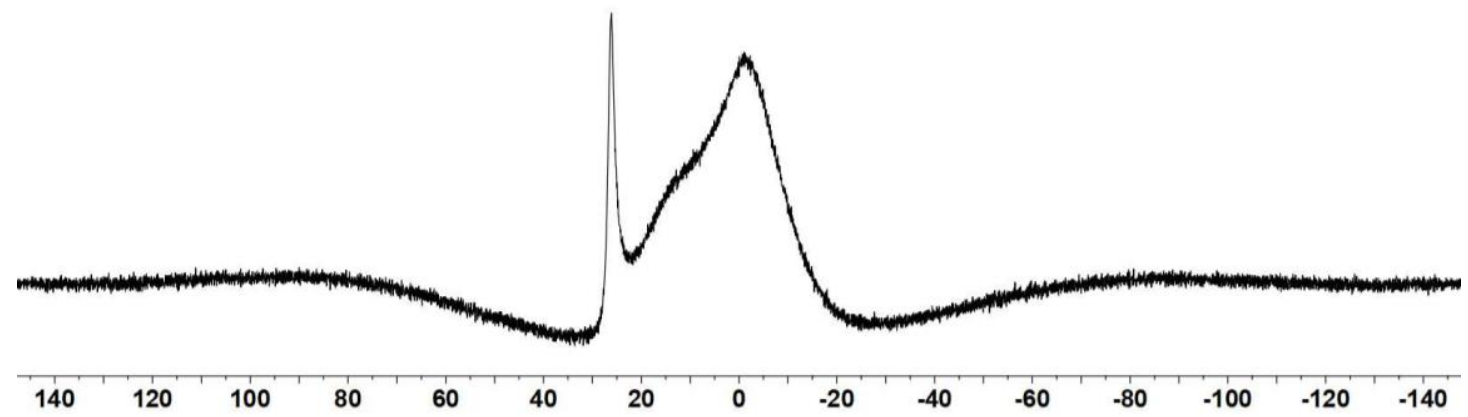

Figure S114. ${ }^{11} \mathrm{~B}\left\{{ }^{1} \mathrm{H}\right\} \mathrm{NMR}\left(192 \mathrm{MHz}\right.$, methylene chloride- $\left.d_{2}, 299 \mathrm{~K}\right)$ spectrum of compound 24a.

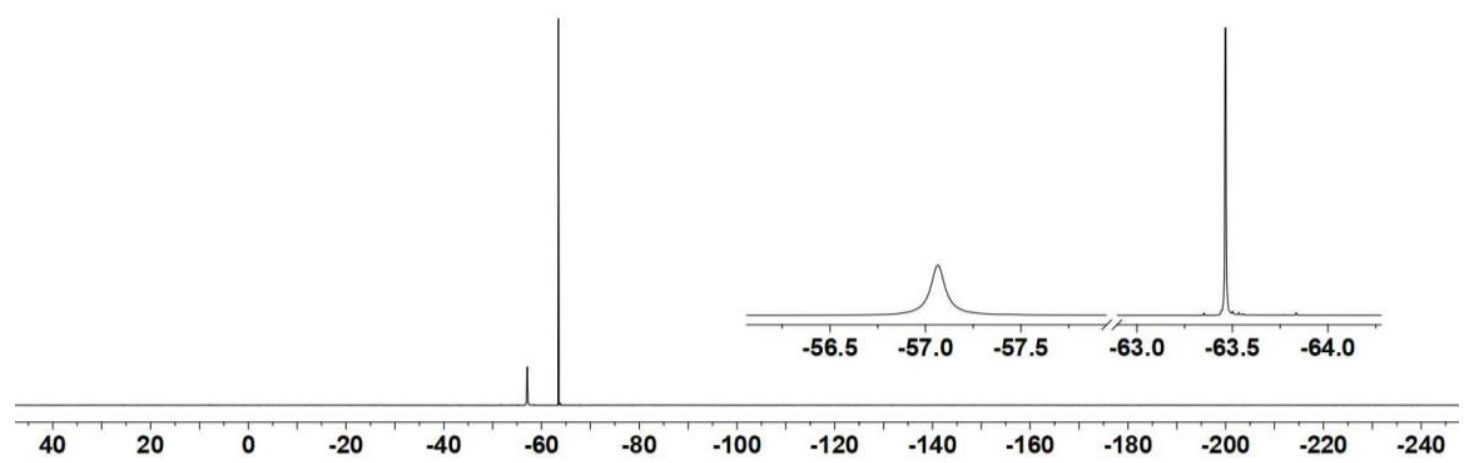

Figure S115. ${ }^{19} \mathrm{~F}$ NMR (564 MHz, methylene chloride- $d_{2}, 299 \mathrm{~K}$ ) spectrum of compound $24 \mathrm{a}$.

The crystal suitable for X-ray diffraction analysis was obtained from the solution of compound 24a in pentane at $-35^{\circ} \mathrm{C}$.

X-ray crystal structure analysis of compound 24a (erk9501): A colorless plate-like specimen of $\mathrm{C}_{41} \mathrm{H}_{32} \mathrm{BF}_{9} \mathrm{~N}_{2}$, approximate dimensions $0.030 \mathrm{~mm} \times 0.130 \mathrm{~mm} \times 0.160 \mathrm{~mm}$, was used for the X-ray crystallographic analysis. The $\mathrm{X}$-ray intensity data were measured. The integration of the data using 
a monoclinic unit cell yielded a total of 12024 reflections to a maximum $\theta$ angle of $25.00^{\circ}(0.84 \AA$ resolution), of which 6305 were independent (average redundancy 1.907 , completeness $=98.9 \%$, $\left.R_{\text {int }}=5.91 \%, R_{\text {sig }}=6.29 \%\right)$ and $4455(70.66 \%)$ were greater than $2 \sigma\left(F^{2}\right)$. The final cell constants of a $=9.3001(3) \AA, \underline{b}=27.1592(10) \AA, \underline{c}=14.5554(5) \AA, \beta=99.578(2)^{\circ}$, volume = 3625.2(2) $\AA^{3}$, are based upon the refinement of the XYZ-centroids of reflections above $20 \sigma(I)$. Data were corrected for absorption effects using the multi-scan method (SADABS). The calculated minimum and maximum transmission coefficients (based on crystal size) are 0.9830 and 0.9970 . The structure was solved and refined using the Bruker SHELXTL Software Package, using the space group $P 2_{1} / n$, with $Z=4$ for the formula unit, $\mathrm{C}_{41} \mathrm{H}_{32} \mathrm{BF}_{9} \mathrm{~N}_{2}$. The final anisotropic full-matrix least-squares refinement on $\mathrm{F}^{2}$ with 514 variables converged at $\mathrm{R} 1=7.97 \%$, for the observed data and $\mathrm{WR} 2=22.84 \%$ for all data. The goodness-of-fit was 1.062. The largest peak in the final difference electron density synthesis was $0.389 \mathrm{e}^{-} / \AA^{3}$ and the largest hole was $-0.262 \mathrm{e}^{-} / \AA^{3}$ with an RMS deviation of $0.064 \mathrm{e}^{-} / \AA^{3}$. On the basis of the final model, the calculated density was $1.346 \mathrm{~g} / \mathrm{cm}^{3}$ and $F(000), 1512 \mathrm{e}-$. The hydrogen at $\mathrm{N} 1$ atom was refined freely. CCDC number: 2041296.

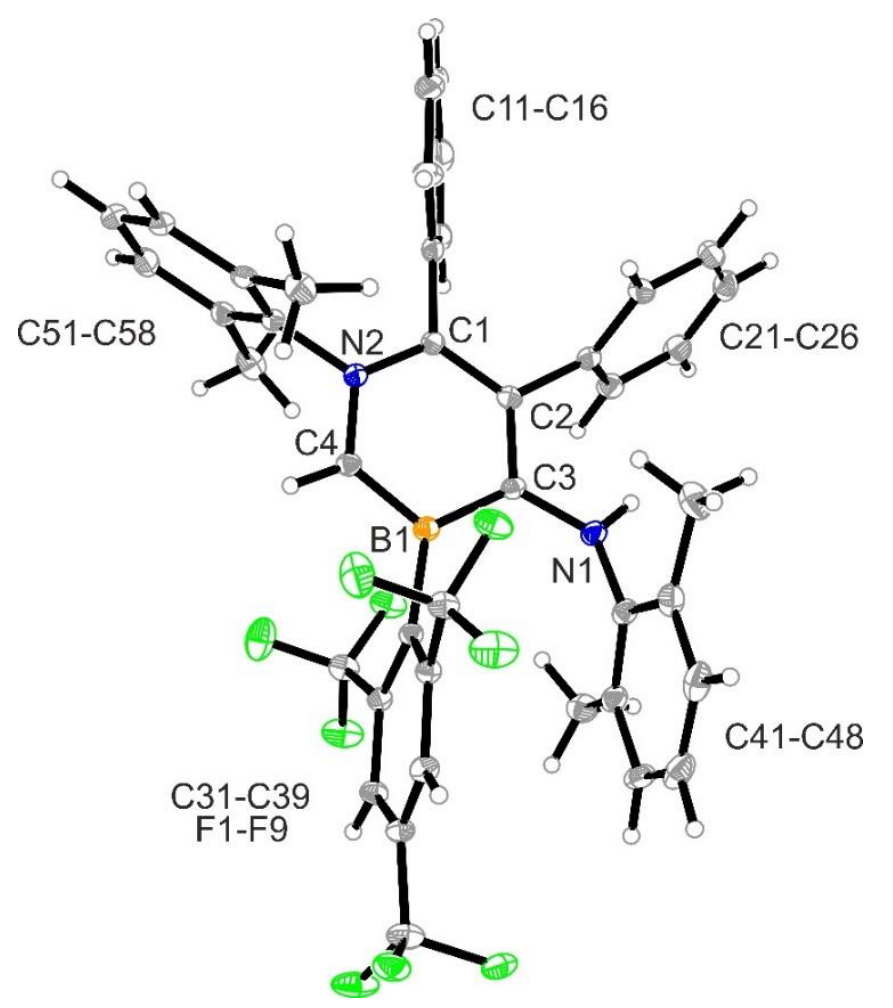

Figure S116. Crystal structure of compound 24a (thermal ellipsoids are set at 15\% probability).

\section{Preparation of the azaborinine derivative 24c}

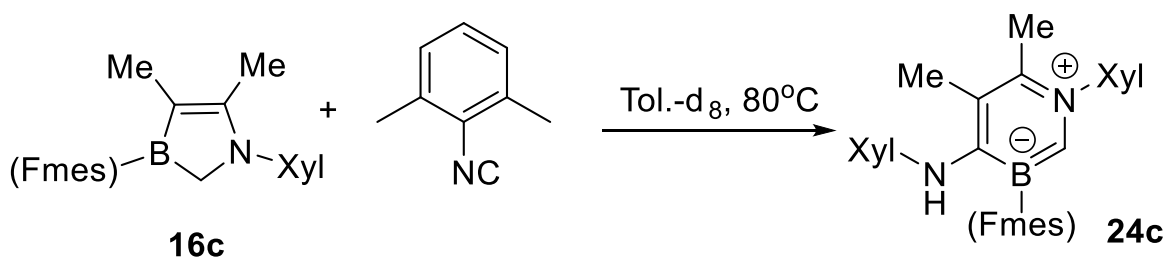

\section{Scheme S34.}

At room temperature, the azaborole $16 \mathrm{c}(71.8 \mathrm{mg}, 0.15 \mathrm{mmol}, 1$ eq.) was added to the solution of 
2,6-dimethylphenyl isocyanide (19.6 $\mathrm{mg}, 0.15 \mathrm{mmol}, 1$ eq.) in $\mathrm{d}_{8}$-toluene $(1 \mathrm{~mL})$ under argon atmosphere in a J. Young tube. The resulting solution was stored at $80^{\circ} \mathrm{C}$ for 7 day. Then all volatiles were removed in vacuo. Subsequently, the residue was dissolved in pentane $(1 \mathrm{~mL})$ and stored at $35^{\circ} \mathrm{C}$ to give the compound $24 \mathrm{c}$ as a yellow solid ( $65 \mathrm{mg}, 71 \%$ yield).

HRMS for $\mathrm{C}_{31} \mathrm{H}_{28} \mathrm{BN}_{2} \mathrm{~F}_{9}{ }^{+}[\mathrm{M}]^{+}$: calc. 610.2202 ; found: 610.2205 .

${ }^{1} \mathrm{H}$ NMR $\left(600 \mathrm{MHz}\right.$, methylene chloride- $\left.d_{2}, 299 \mathrm{~K}\right): \delta=8.11\left(\mathrm{~s}, 2 \mathrm{H}, m\right.$-Fmes), $7.22\left(\mathrm{~m}, 1 \mathrm{H}, p\right.$-Xyl| $\left.{ }^{(1)}\right)$, $7.16\left(\mathrm{~m}, 2 \mathrm{H}, m-\mathrm{XY|}^{(1)}\right), 6.96\left(\mathrm{~m}, 2 \mathrm{H}, m-\mathrm{XYl}^{(4)}\right), 6.92\left(\mathrm{~m}, 1 \mathrm{H}, p-\left.\mathrm{XY}\right|^{(4)}\right), 6.50(\mathrm{~s}, 1 \mathrm{H}, \mathrm{C}(2) \mathrm{H}), 5.36(\mathrm{~s}, 1 \mathrm{H}$, $\mathrm{NH}), 2.09\left(\mathrm{~s}, 6 \mathrm{H}, o-\mathrm{CH}_{3}{ }^{\mathrm{Xy}(4)}\right), 2.01\left(\mathrm{~s}, 6 \mathrm{H}, o-\mathrm{CH}_{3}{ }^{\mathrm{Xy}(1)}\right), 1.98\left(\mathrm{~s}, 3 \mathrm{H}, \mathrm{CH}_{3}{ }^{(6)}\right), 1.62\left(\mathrm{~s}, 3 \mathrm{H}, \mathrm{CH}_{3}{ }^{(5)}\right)$.

${ }^{13} \mathrm{C}\left\{{ }^{1} \mathrm{H}\right\}$ NMR (151 MHz, methylene chloride- $\left.d_{2}, 299 \mathrm{~K}\right): \delta=163.0$ (br, C(4)), 149.7 (br, i-Fmes), 146.5 $\left(i-\mathrm{XYl}^{(1)}\right), 141.9\left(i-\mathrm{Xyl}{ }^{(4)}\right), 136.8\left(\mathrm{q},{ }^{2} \mathrm{~J}_{\mathrm{FC}}=29.3 \mathrm{~Hz}, o-\mathrm{Fmes}\right), 135.9(\mathrm{br}, \mathrm{C}(2) \mathrm{H}), 134.8(\mathrm{C}(6)), 134.3$ (o-

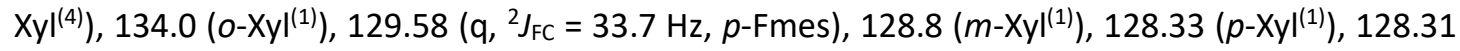
$\left(m-\mathrm{Xyl}{ }^{(4)}\right), 125.5\left(\mathrm{br}, m\right.$-Fmes), $124.8\left(p-\mathrm{XYl}^{(4)}\right), 124.3\left(\mathrm{q},{ }^{1} J_{\mathrm{FC}}=275.3 \mathrm{~Hz}, o-\mathrm{CF}_{3}\right), 123.8\left(\mathrm{q},{ }^{1} J_{\mathrm{FC}}=272.7\right.$ $\left.\mathrm{Hz}, p-\mathrm{CF}_{3}\right), 118.6(\mathrm{C}(3)), 18.9\left(\mathrm{q}, J=2.1 \mathrm{~Hz}, \mathrm{o}-\mathrm{CH}_{3}{ }^{\mathrm{Xy}(4)}\right), 17.2\left(\mathrm{CH}_{3}{ }^{(6)}\right), 16.9\left(\mathrm{o}-\mathrm{CH}_{3}{ }^{\mathrm{Xy}(1)}\right), 16.3\left(\mathrm{CH}_{3}{ }^{(5)}\right)$. ${ }^{11} \mathrm{~B}\left\{{ }^{1} \mathrm{H}\right\}$ NMR $\left(192 \mathrm{MHz}\right.$, methylene chloride- $\left.d_{2}, 299 \mathrm{~K}\right): \delta=26.3\left(\mathrm{v}_{1 / 2} \approx 280 \mathrm{~Hz}\right)$.

${ }^{19} \mathrm{~F}$ NMR $\left(564 \mathrm{MHz}\right.$, methylene chloride- $\left.d_{2}, 299 \mathrm{~K}\right): \delta=-58.6\left(\mathrm{~s}, 2 \mathrm{~F}, o-\mathrm{CF}_{3}\right),-63.4\left(\mathrm{~s}, 1 \mathrm{~F}, p-\mathrm{CF}_{3}\right)$.

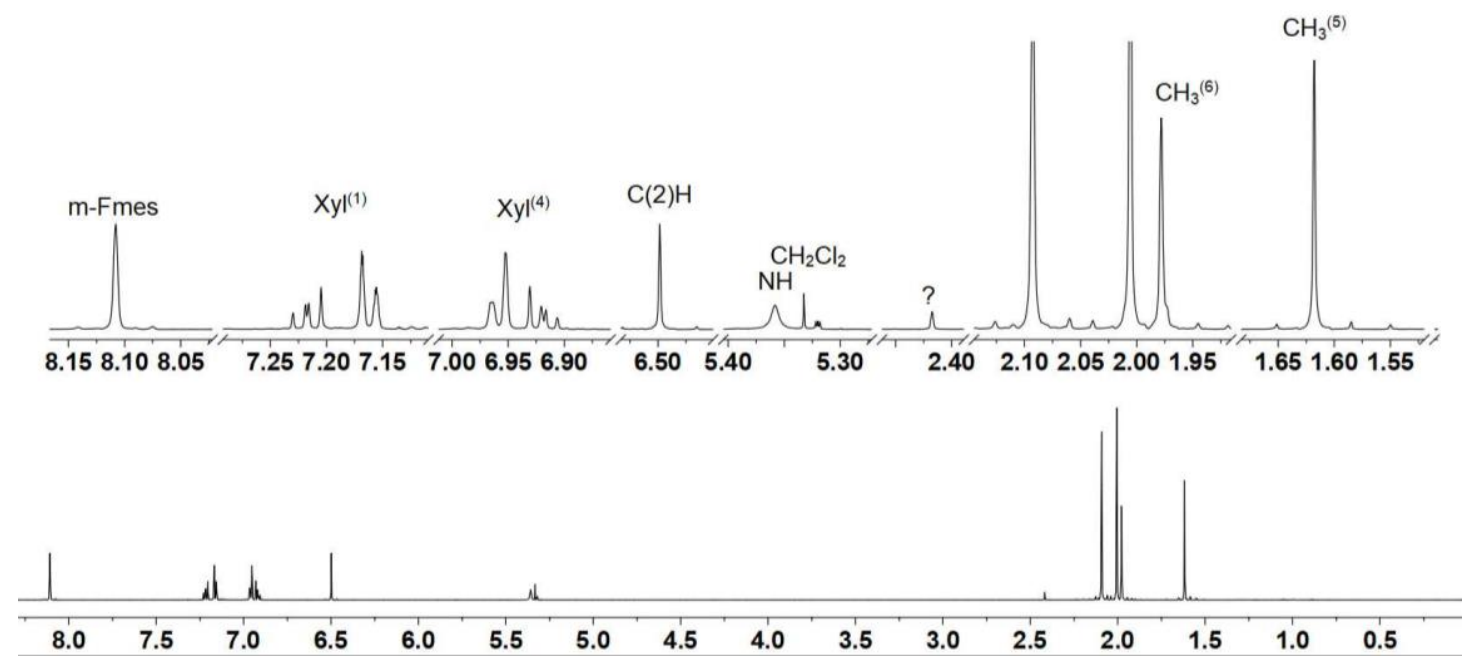

Figure S117. ${ }^{1} \mathrm{H}$ NMR (600 MHz, methylene chloride- $d_{2}, 299 \mathrm{~K}$ ) spectrum of compound $24 \mathrm{c}$.

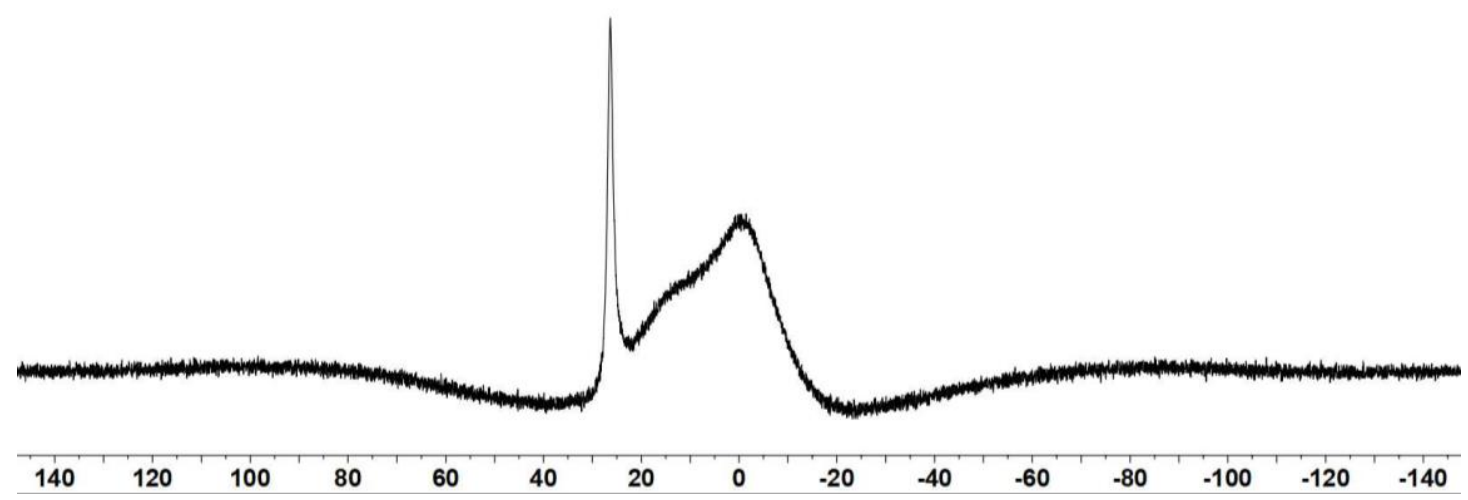

Figure S118. ${ }^{11} \mathrm{~B}\left\{{ }^{1} \mathrm{H}\right\}$ NMR (192 MHz, methylene chloride- $\left.d_{2}, 299 \mathrm{~K}\right)$ spectrum of compound 24c. 


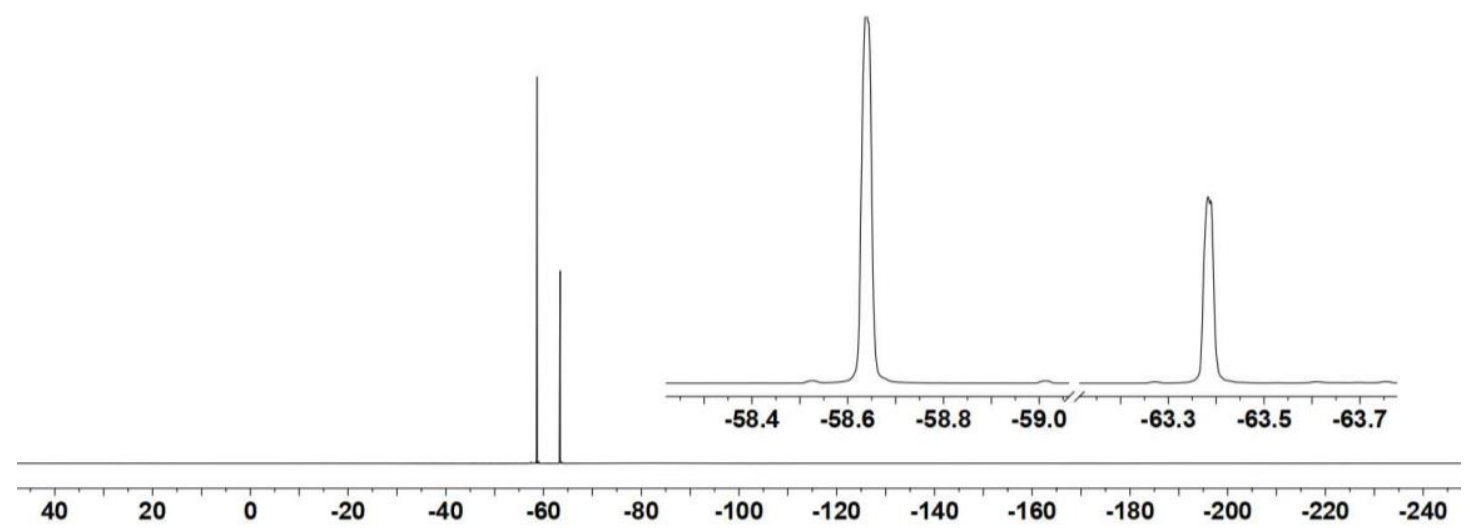

Figure S119. ${ }^{19} \mathrm{~F}$ NMR (564 MHz, methylene chloride- $d_{2}, 299 \mathrm{~K}$ ) spectrum of compound 24c.

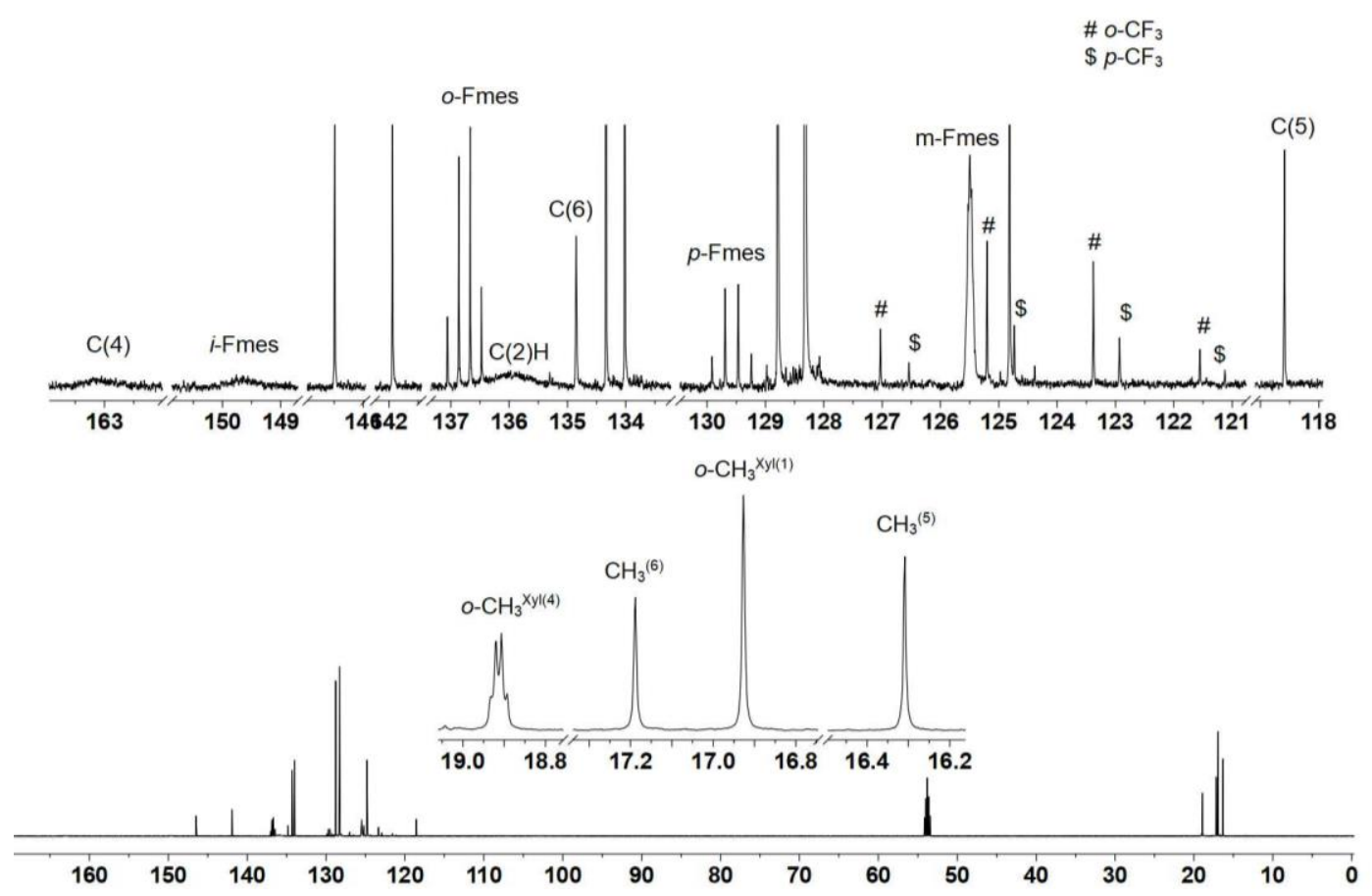

Figure S120. ${ }^{13} \mathrm{C}\left\{{ }^{1} \mathrm{H}\right\}$ NMR $\left(151 \mathrm{MHz}\right.$, methylene chloride- $\left.d_{2}, 299 \mathrm{~K}\right)$ spectrum of compound $24 \mathrm{c}$.

The crystal suitable for X-ray diffraction analysis was obtained from the solution of the compound $24 \mathrm{c}$ in pentane at $-35^{\circ} \mathrm{C}$.

X-ray crystal structure analysis of compound 24c (erk9568): A yellow prism-like specimen of $\mathrm{C}_{31} \mathrm{H}_{28} \mathrm{BF}_{9} \mathrm{~N}_{2}$, approximate dimensions $0.140 \mathrm{~mm} \times 0.160 \mathrm{~mm} \times 0.280 \mathrm{~mm}$, was used for the X-ray crystallographic analysis. The X-ray intensity data were measured. A total of 1643 frames were collected. The total exposure time was 23.61 hours. The frames were integrated with the Bruker SAINT software package using a wide-frame algorithm. The integration of the data using a triclinic unit cell yielded a total of 24094 reflections to a maximum $\theta$ angle of $66.64^{\circ}$ ( $0.84 \AA$ resolution), of which 5870 were independent (average redundancy 4.105 , completeness $=99.4 \%, R_{\text {int }}=5.84 \%, R_{\text {sig }}$ $=4.93 \%)$ and $4134(70.43 \%)$ were greater than $2 \sigma\left(F^{2}\right)$. The final cell constants of $\underline{a}=8.6995(3) \AA, \underline{b}$ $=12.2055(4) \AA, \underline{c}=15.8773(5) \AA, \alpha=95.526(2)^{\circ}, \beta=90.646(2)^{\circ}, \gamma=96.315(2)^{\circ}$, volume $=$ $1667.45(10) \AA^{3}$, are based upon the refinement of the XYZ-centroids of 4212 reflections above 20 $\sigma(\mathrm{I})$ with $7.322^{\circ}<2 \theta<132.8^{\circ}$. Data were corrected for absorption effects using the multi-scan 
method (SADABS). The ratio of minimum to maximum apparent transmission was 0.834 . The calculated minimum and maximum transmission coefficients (based on crystal size) are 0.7830 and 0.8820. The structure was solved and refined using the Bruker SHELXTL Software Package, using the space group $P-1$, with $Z=2$ for the formula unit, $\mathrm{C}_{31} \mathrm{H}_{28} \mathrm{BF}_{9} \mathrm{~N}_{2}$. The final anisotropic full-matrix least-squares refinement on $\mathrm{F}^{2}$ with 426 variables converged at $\mathrm{R} 1=4.56 \%$, for the observed data and $\mathrm{WR2}=12.11 \%$ for all data. The goodness-of-fit was 1.036 . The largest peak in the final difference electron density synthesis was $0.207 \mathrm{e}^{-} / \AA^{3}$ and the largest hole was $-0.201 \mathrm{e}^{-} / \AA^{3}$ with an RMS deviation of $0.041 \mathrm{e}^{-/} / \AA^{3}$. On the basis of the final model, the calculated density was 1.216 $\mathrm{g} / \mathrm{cm}^{3}$ and $\mathrm{F}(000), 628 \mathrm{e}$. The hydrogen at $\mathrm{N} 1$ atom was refined freely. CCDC number: 2041297.

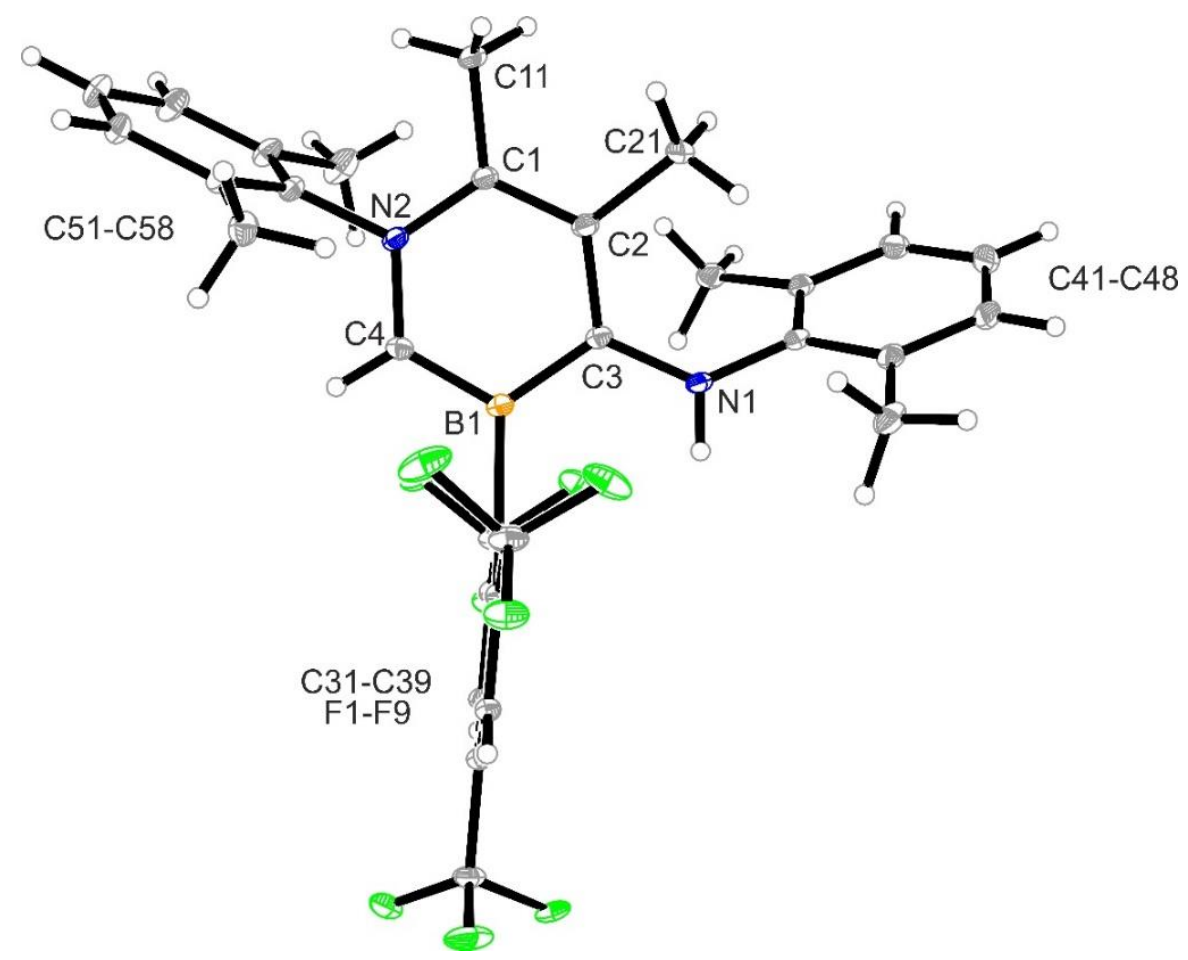

Figure S121. Crystal structure of compound 24c (thermal ellipsoids are set at 15\% probability).

\section{Preparation of the azaborinine derivative $24 \mathrm{~d}$}

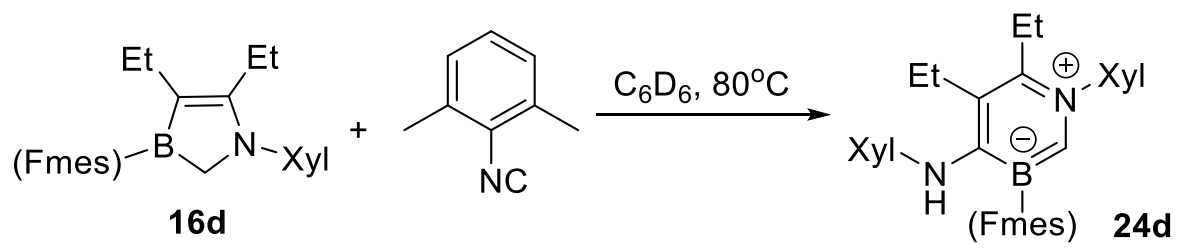

\section{Scheme S35.}

At room temperature, the azaborole $16 \mathrm{~d}(101.4 \mathrm{mg}, 0.2 \mathrm{mmol}, 1 \mathrm{eq}$.) was added to a solution of 2,6-dimethylphenyl isocyanide (26.2 $\mathrm{mg}, 0.2 \mathrm{mmol}, 1$ eq.) in $\mathrm{C}_{6} \mathrm{D}_{6}(2 \mathrm{~mL})$ under an argon atmosphere in a J. Young tube. The resulting solution was stored at $80{ }^{\circ} \mathrm{C}$ for 7 days. Then all volatiles were removed in vacuo. Subsequently, the residue was dissolved in pentane $(1 \mathrm{~mL})$ and stored at $-35{ }^{\circ} \mathrm{C}$ to finally give the compound $\mathbf{2 4 d}$ as a yellow solid ( $72 \mathrm{mg}, 57 \%$ yield).

HRMS for $\mathrm{C}_{33} \mathrm{H}_{32} \mathrm{BF}_{9} \mathrm{~N}_{2}{ }^{+}[\mathrm{M}]^{+}$: calc. 638.2515; found: 638.2517 . 
${ }^{1} \mathrm{H}$ NMR $\left(600 \mathrm{MHz}\right.$, methylene chloride- $\left.d_{2}, 299 \mathrm{~K}\right): \delta=7.99$ (s, $2 \mathrm{H}, m$-Fmes), $7.23\left(\mathrm{~m}, 1 \mathrm{H}, p\right.$-Xyl $\left.{ }^{(1)}\right)$, $7.16\left(\mathrm{~m}, 2 \mathrm{H}, m-\mathrm{Xy}^{(1)}\right), 6.86\left(\mathrm{~m}, 3 \mathrm{H}, m-\mathrm{Xy}^{(4)}, p-\mathrm{Xy}^{(4)}\right), 6.42(\mathrm{~s}, 1 \mathrm{H}, \mathrm{C}(2) \mathrm{H}), 5.42(\mathrm{~s}, 1 \mathrm{H}, \mathrm{NH}), 2.45(\mathrm{q}$, $\left.{ }^{3} J_{\mathrm{HH}}=7.4 \mathrm{~Hz}, 2 \mathrm{H}, \mathrm{CH}_{2}^{\mathrm{Et}(6)}\right), 2.38\left(q^{3}{ }^{3} \mathrm{JHH}=7.4 \mathrm{~Hz}, 2 \mathrm{H}, \mathrm{CH}_{2}{ }^{\mathrm{Et}(5)}\right), 2.08\left(\mathrm{~s}, 6 \mathrm{H}, o_{-} \mathrm{CH}_{3}{ }^{X \mathrm{Xy}(4)}\right), 2.04(\mathrm{~s}, 6 \mathrm{H}, o-$ $\left.\mathrm{CH}_{3}{ }^{\mathrm{Xy}(1)}\right), 0.99\left(\mathrm{t},{ }^{3} J_{\mathrm{HH}}=7.4 \mathrm{~Hz}, 3 \mathrm{H}, \mathrm{CH}_{3}{ }^{\mathrm{Et}(6)}\right), 0.94\left(\mathrm{t},{ }^{3} \mathrm{~J}_{\mathrm{HH}}=7.4 \mathrm{~Hz}, 3 \mathrm{H}, \mathrm{CH}_{3}{ }^{\mathrm{Et}(5)}\right)$.

${ }^{13} \mathrm{C}\left\{{ }^{1} \mathrm{H}\right\}$ NMR (151 MHz, methylene chloride- $\left.d_{2}, 299 \mathrm{~K}\right): \delta=162.3(\mathrm{br}, \mathrm{C}(4)), 149.8$ (br, $\left.i-\mathrm{Fmes}\right), 146.4$ $\left(i-\mathrm{Xyl}{ }^{(1)}\right), 141.1\left(i-\mathrm{Xyl}\left({ }^{(4)}\right), 139.4(\mathrm{C}(6)), 136.8(\mathrm{br}, \mathrm{C}(2) \mathrm{H}), 136.3\right.$ (q, $\left.{ }^{2} \mathrm{~J}_{\mathrm{FC}}=29.2 \mathrm{~Hz}, o-\mathrm{Fmes}\right), 134.6$ (o$\left.\mathrm{XY}^{(4)}\right), 134.2\left(o-\mathrm{XYl}^{(1)}\right), 129.3\left(\mathrm{q}^{2} \mathrm{~J}_{\mathrm{FC}}=33.8 \mathrm{~Hz}, p\right.$-Fmes$), 128.8\left(m-\mathrm{XYl}^{(1)}\right), 128.4\left(m-\mathrm{XYl}^{(4)}\right), 128.3(p-$ $\mathrm{Xy}\left({ }^{(1)}\right), 125.9(\mathrm{C}(5)), 125.2$ (br, $m$-Fmes), $124.9\left(p-\mathrm{Xy}^{(4)}\right), 23.7\left(\mathrm{CH}_{2}^{\mathrm{Et}(6)}\right), 20.9\left(\mathrm{CH}_{2}^{\mathrm{Et}(5)}\right), 19.0\left(\mathrm{q}, J_{\mathrm{FC}}=\right.$ $\left.2.2 \mathrm{~Hz}, o-\mathrm{CH}_{3}{ }^{\mathrm{Xy}(4)}\right), 17.2\left(o-\mathrm{CH}_{3}{ }^{\mathrm{Xy}(1)}\right), 14.4\left(\mathrm{CH}_{3}^{\mathrm{Et}(5)}\right), 13.6\left(\mathrm{CH}_{3}{ }^{\mathrm{Et}(6)}\right)$.

${ }^{11} \mathrm{~B}\left\{{ }^{1} \mathrm{H}\right\}$ NMR $\left(192 \mathrm{MHz}\right.$, methylene chloride- $\left.d_{2}, 299 \mathrm{~K}\right): \delta=26.4\left(\mathrm{v}_{1 / 2} \approx 310 \mathrm{~Hz}\right)$.

${ }^{19} \mathrm{~F} \mathrm{NMR}\left(564 \mathrm{MHz}\right.$, methylene chloride- $\left.d_{2}, 299 \mathrm{~K}\right): \delta=-58.3\left(\mathrm{~s}, 2 \mathrm{~F}, o-\mathrm{CF}_{3}{ }^{\mathrm{Fmes}}\right),-63.4\left(\mathrm{~s}, 1 \mathrm{~F}, p-\mathrm{CF}_{3}{ }^{\mathrm{Fmes}}\right)$.
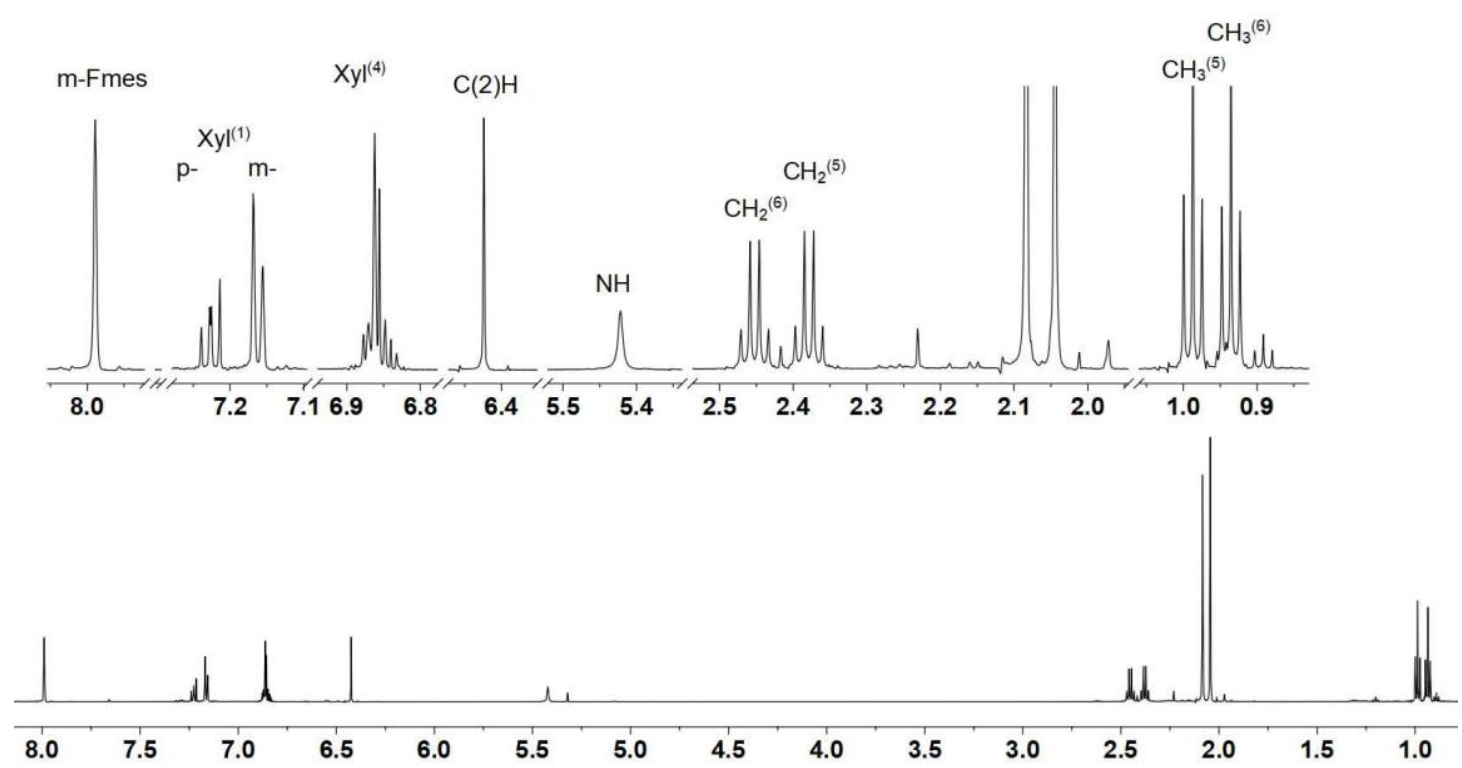

Figure S122. ${ }^{1} \mathrm{H}$ NMR $\left(600 \mathrm{MHz}\right.$, methylene chloride- $\left.d_{2}, 299 \mathrm{~K}\right)$ spectrum of compound $24 \mathrm{~d}$.

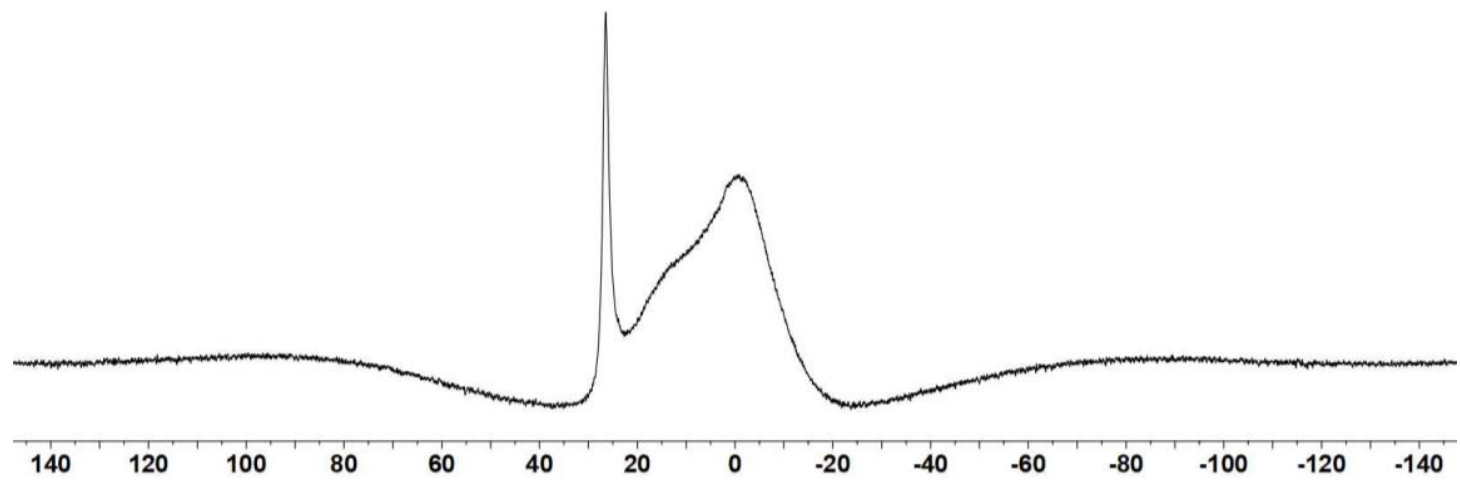

Figure S123. ${ }^{11} \mathrm{~B}\left\{{ }^{1} \mathrm{H}\right\}$ NMR (192 MHz, methylene chloride- $d_{2}, 299 \mathrm{~K}$ ) spectrum of compound $24 \mathrm{~d}$. 


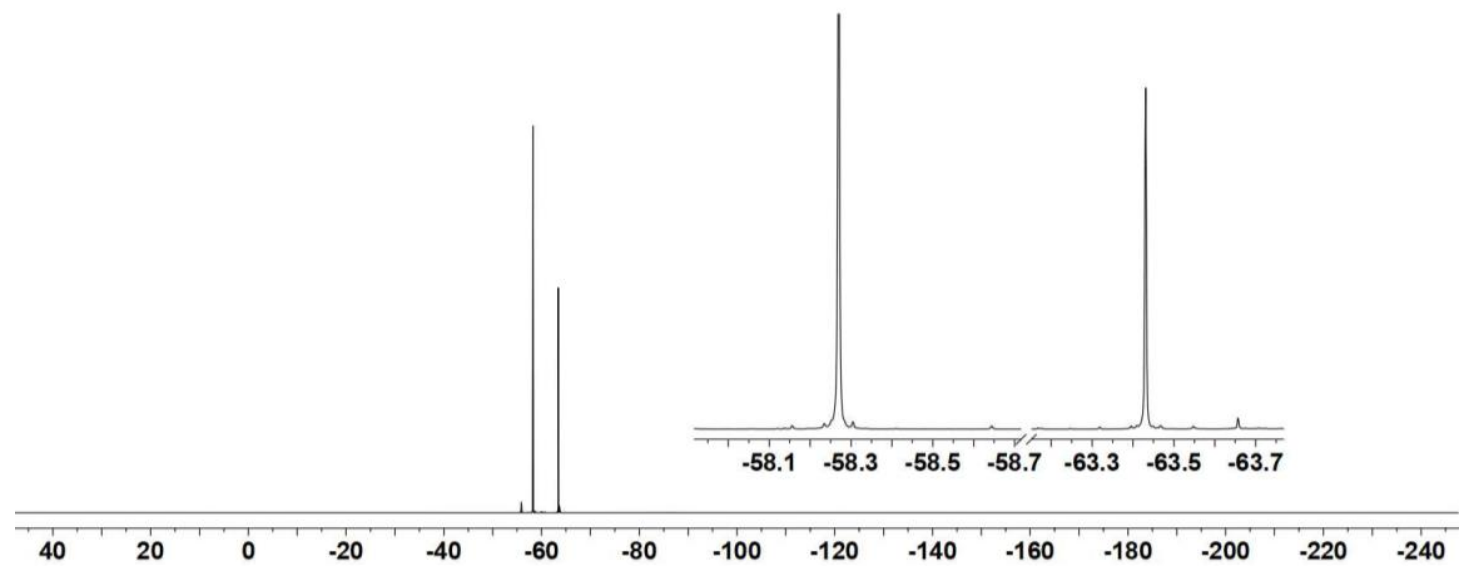

Figure S124. ${ }^{19} \mathrm{~F}$ NMR (564 MHz, methylene chloride- $d_{2}, 299 \mathrm{~K}$ ) spectrum of compound 24d.

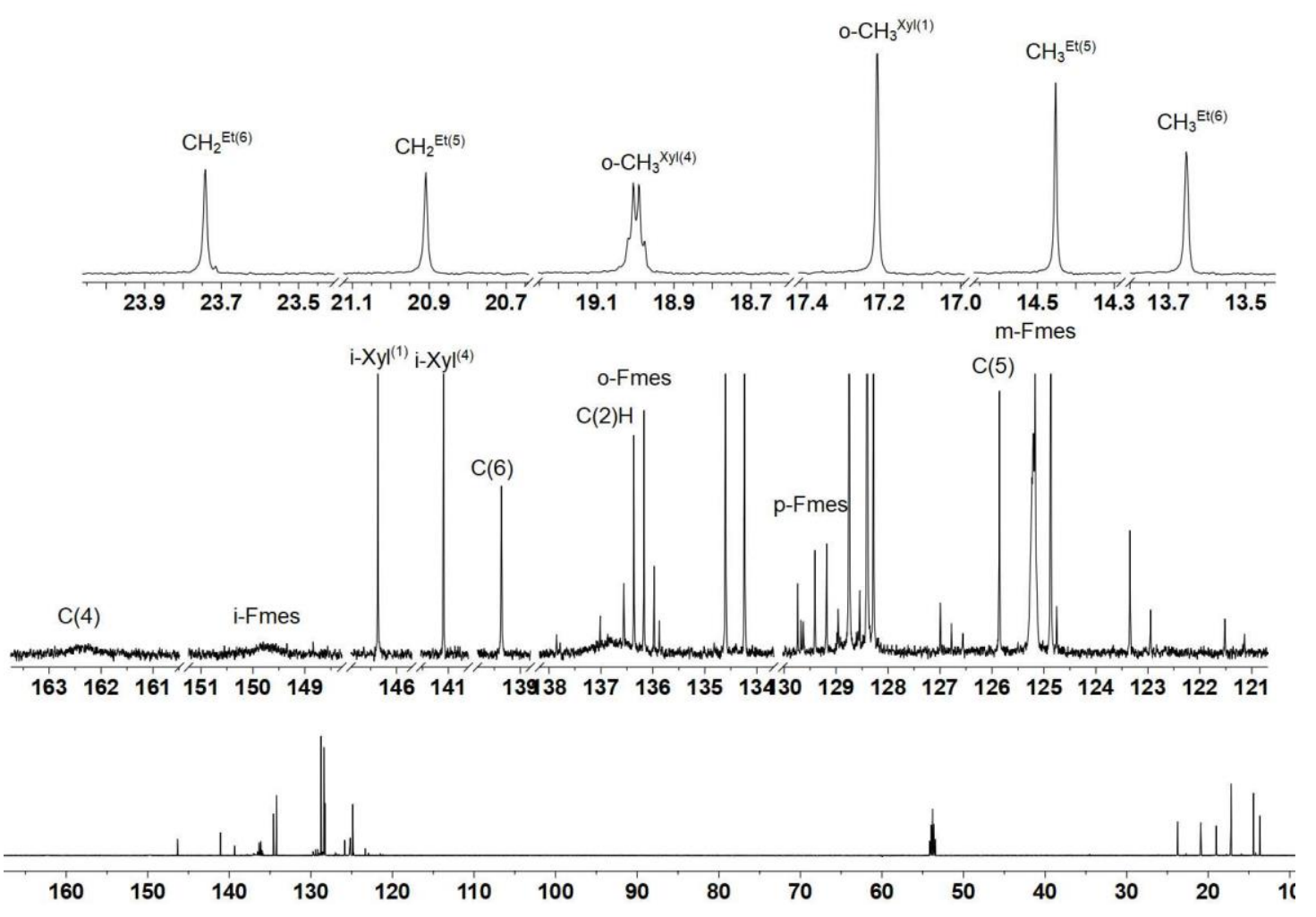

Figure S125. ${ }^{13} \mathrm{C}\left\{{ }^{1} \mathrm{H}\right\}$ NMR (151 MHz, methylene chloride- $\left.d_{2}, 299 \mathrm{~K}\right)$ spectrum of compound $24 \mathrm{~d}$.

The crystal suitable for $\mathrm{X}$-ray diffraction analysis was obtained from the solution of compound $\mathbf{2 4 d}$ in pentane at $-35^{\circ} \mathrm{C}$.

X-ray crystal structure analysis of compound 24d (erk9597): A pale yellow plate-like specimen of $\mathrm{C}_{33} \mathrm{H}_{32} \mathrm{BF}_{9} \mathrm{~N}_{2}$, approximate dimensions $0.041 \mathrm{~mm} \times 0.124 \mathrm{~mm} \times 0.156 \mathrm{~mm}$, was used for the X-ray crystallographic analysis. The $\mathrm{X}$-ray intensity data were measured. A total of 1479 frames were collected. The total exposure time was 27.67 hours. The frames were integrated with the Bruker SAINT software package using a wide-frame algorithm. The integration of the data using a monoclinic unit cell yielded a total of 45950 reflections to a maximum $\theta$ angle of $68.53^{\circ}$ ( $0.83 \AA$ resolution), of which 5620 were independent (average redundancy 8.176, completeness $=99.2 \%$, 
$\left.R_{\text {int }}=7.85 \%, R_{\text {sig }}=4.41 \%\right)$ and $4126(73.42 \%)$ were greater than $2 \sigma\left(F^{2}\right)$. The final cell constants of $\underline{a}$ $=11.2377(3) \AA, \underline{b}=11.1974(2) \AA, \underline{c}=24.4577(6) \AA, \beta=90.739(2)^{\circ}$, volume $=3077.33(12) \AA^{3}$, are based upon the refinement of the $X Y Z$-centroids of 7201 reflections above $20 \sigma(\mathrm{I})$ with $7.229^{\circ}<2 \theta$ $<136.2^{\circ}$. Data were corrected for absorption effects using the multi-scan method (SADABS). The ratio of minimum to maximum apparent transmission was 0.901 . The calculated minimum and maximum transmission coefficients (based on crystal size) are 0.8570 and 0.9590 . The structure was solved and refined using the Bruker SHELXTL Software Package, using the space group $P 2_{1} / C$, with $Z=4$ for the formula unit, $\mathrm{C}_{33} \mathrm{H}_{32} \mathrm{BF}_{9} \mathrm{~N}_{2}$. The final anisotropic full-matrix least-squares refinement on $\mathrm{F}^{2}$ with 444 variables converged at $\mathrm{R} 1=5.59 \%$, for the observed data and $\mathrm{wR} 2=$ $14.89 \%$ for all data. The goodness-of-fit was 1.030. The largest peak in the final difference electron density synthesis was $0.337 \mathrm{e}^{-} / \AA^{3}$ and the largest hole was $-0.228 \mathrm{e}^{-} / \AA^{3}$ with an $\mathrm{RMS}$ deviation of $0.053 \mathrm{e}^{-} / \AA^{3}$. On the basis of the final model, the calculated density was $1.378 \mathrm{~g} / \mathrm{cm}^{3}$ and $F(000)$, $1320 \mathrm{e}^{-}$. The hydrogen at N1 atom was refined freely. CCDC number: 2041298.

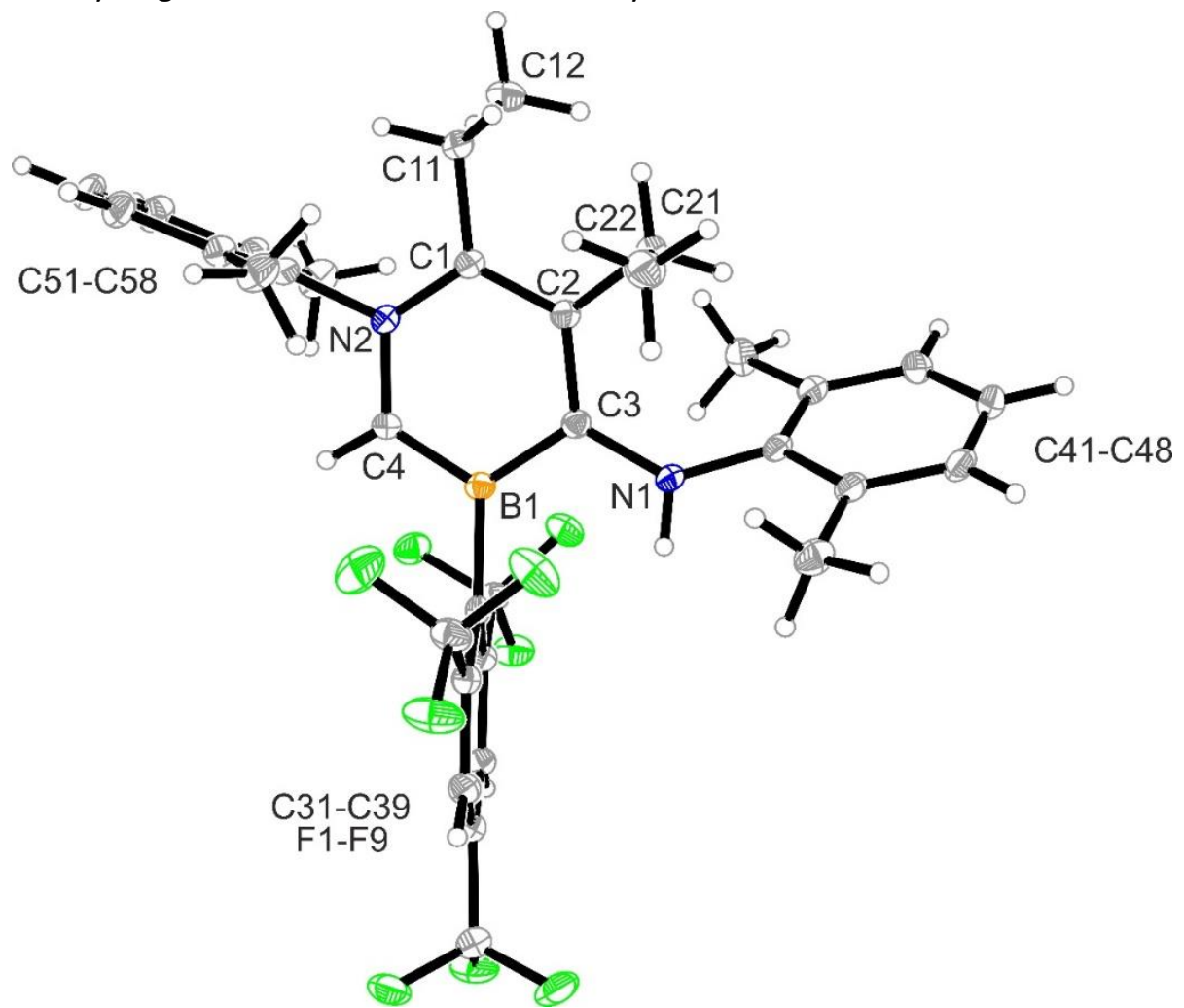

Figure S126. Crystal structure of compound 24d (thermal ellipsoids are set at 15\% probability).

\section{Preparation of the azaborinine derivative $24 \mathrm{e}$}

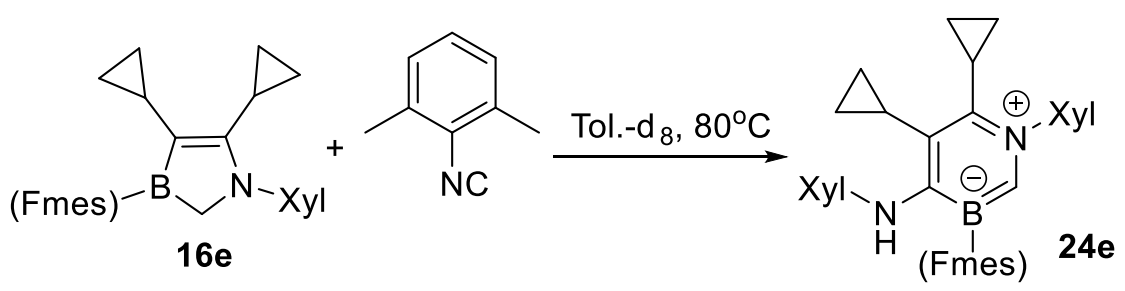

Scheme S36. 
At room temperature, the azaborole $16 \mathrm{e}(106 \mathrm{mg}, 0.2 \mathrm{mmol}, 1 \mathrm{eq}$.) was added to a solution of 2,6dimethylphenyl isocyanide $\left(26.2 \mathrm{mg}, 0.2 \mathrm{mmol}, 1\right.$ eq.) in $\mathrm{d}_{8}$-toluene $(1 \mathrm{~mL})$ under an argon atmosphere in a J. Young tube. The resulting solution was stored at $80^{\circ} \mathrm{C}$ for 1 day. Then all volatiles were removed in vacuo and the residue was dissolved in pentane $(1 \mathrm{~mL})$ and stored at $-35{ }^{\circ} \mathrm{C}$ to finally give the compound $24 \mathrm{e}$ as a yellow solid ( $95 \mathrm{mg}$, $72 \%$ yield). HRMS for $\mathrm{C}_{35} \mathrm{H}_{33} \mathrm{BN}_{2} \mathrm{Fg}_{9}{ }^{+}[\mathrm{M}+\mathrm{H}]^{+}$: calc. 663.2594; found: 663.2968 .

${ }^{1} \mathrm{H}$ NMR $\left(600 \mathrm{MHz}\right.$, methylene chloride- $\left.d_{2}, 299 \mathrm{~K}\right): \delta=8.10$ (s, $2 \mathrm{H}, m$-Fmes), $7.19\left(\mathrm{~m}, 1 \mathrm{H}, p\right.$-Xyl| $\left.{ }^{(1)}\right)$, $7.14\left(\mathrm{~m}, 2 \mathrm{H}, m-\mathrm{Xy}^{(1)}\right), 6.92\left(\mathrm{~m}, 2 \mathrm{H}, m-\mathrm{Xy}^{(4)}\right), 6.86\left(\mathrm{~m}, 1 \mathrm{H}, p-\mathrm{Xy}{ }^{(4)}\right), 6.49(\mathrm{~s}, 1 \mathrm{H}, \mathrm{C}(2) \mathrm{H}), 5.60(\mathrm{~s}, 1 \mathrm{H}$, $\mathrm{NH}), 2.05\left(\mathrm{~s}, 6 \mathrm{H}, o-\mathrm{CH}_{3}{ }^{\mathrm{Xy}(4)}\right), 2.01\left(\mathrm{~s}, 6 \mathrm{H}, o-\mathrm{CH}_{3}{ }^{\mathrm{Xy}(1)}\right), 1.50\left(p,{ }^{3} \mathrm{HHH}_{\mathrm{H}}=7.1 \mathrm{~Hz}, 1 \mathrm{H}, \mathrm{CH}^{\mathrm{cp}(6)}\right), 0.93(\mathrm{~m}, 1 \mathrm{H}$, $\left.\mathrm{CH}^{\mathrm{cp}(5)}\right), 0.58\left(\mathrm{~m}, 4 \mathrm{H}, \mathrm{CH}_{2}{ }^{\mathrm{cp}(6)}\right), 0.32\left(\mathrm{~m}, 4 \mathrm{H}, \mathrm{CH}_{2}{ }^{\mathrm{cp}(5)}\right)$.

${ }^{13} \mathrm{C}\left\{{ }^{1} \mathrm{H}\right\}$ NMR (151 MHz, methylene chloride- $\left.d_{2}, 299 \mathrm{~K}\right): \delta=164.9$ (br, C(4)), 149.4 (br, i-Fmes), 146.8 $\left(i-\mathrm{XYl}^{(1)}\right), 142.0\left(i-\mathrm{Xy}{ }^{(4)}\right), 141.2(\mathrm{C}(6)), 137.3(\mathrm{br}, \mathrm{C}(2)), 136.8$ (q, $\left.{ }^{2} \mathrm{JFC}_{\mathrm{FC}}=29.3 \mathrm{~Hz}, o-\mathrm{Fmes}\right), 133.8$ (o$\left.\mathrm{XY}^{(1)}\right), 133.0\left(o-\mathrm{XYl}^{(4)}\right), 129.6\left(\mathrm{q}^{2} \mathrm{~J}_{\mathrm{FC}}=33.8 \mathrm{~Hz}, p\right.$-Fmes$), 128.7\left(m-\mathrm{Xyl}^{(1)}\right), 128.2\left(m-\mathrm{XYY}^{(4)}\right), 128.0(p-$ $\left.\mathrm{Xy}{ }^{(1)}\right), 127.7(\mathrm{C}(5)), 125.4$ (br, $m$-Fmes), 124.2 (q, $\left.{ }^{1} \mathrm{~J}_{\mathrm{FC}}=275.5 \mathrm{~Hz}, o-\mathrm{CF}_{3}{ }^{\text {Fmes }}\right), 124.1\left(p-\left.\mathrm{Xy}\right|^{(4)}\right), 123.8$ $\left(q,{ }^{1} \mathrm{JFC}_{\mathrm{FC}}=272.3 \mathrm{~Hz}, p-\mathrm{CF}_{3}{ }^{\mathrm{Fmes}}\right), 19.1\left(\mathrm{q}, \mathrm{J}_{\mathrm{FC}}=1.8 \mathrm{~Hz}, o-\mathrm{CH}_{3}{ }^{\mathrm{Xy}(4)}\right), 17.6\left(o-\mathrm{CH}_{3}{ }^{\mathrm{Xy}(1)}\right), 15.0\left(\mathrm{CH}^{\mathrm{cp}(6)}\right), 14.4$ $\left(\mathrm{CH}^{\mathrm{cp}(5)}\right), 10.8\left(\mathrm{CH}_{2}{ }^{\mathrm{cp}(5)}\right), 9.2\left(\mathrm{CH}_{2}{ }^{\mathrm{cp}(6)}\right)$.

${ }^{11} \mathrm{~B}\left\{{ }^{1} \mathrm{H}\right\}$ NMR $\left(192 \mathrm{MHz}\right.$, methylene chloride $\left.-d_{2}, 299 \mathrm{~K}\right): \delta=26.2\left(\mathrm{v}_{1 / 2} \approx 280 \mathrm{~Hz}\right)$.

${ }^{19} \mathrm{~F}$ NMR $\left(564 \mathrm{MHz}\right.$, methylene chloride- $\left.d_{2}, 299 \mathrm{~K}\right): \delta-59.0\left(\mathrm{~s}, 2 \mathrm{~F}, o-\mathrm{CF}_{3}{ }^{\mathrm{Fmes}}\right),-63.4\left(\mathrm{~s}, 1 \mathrm{~F}, p-\mathrm{CF}_{3}{ }^{\mathrm{Fmes}}\right)$.

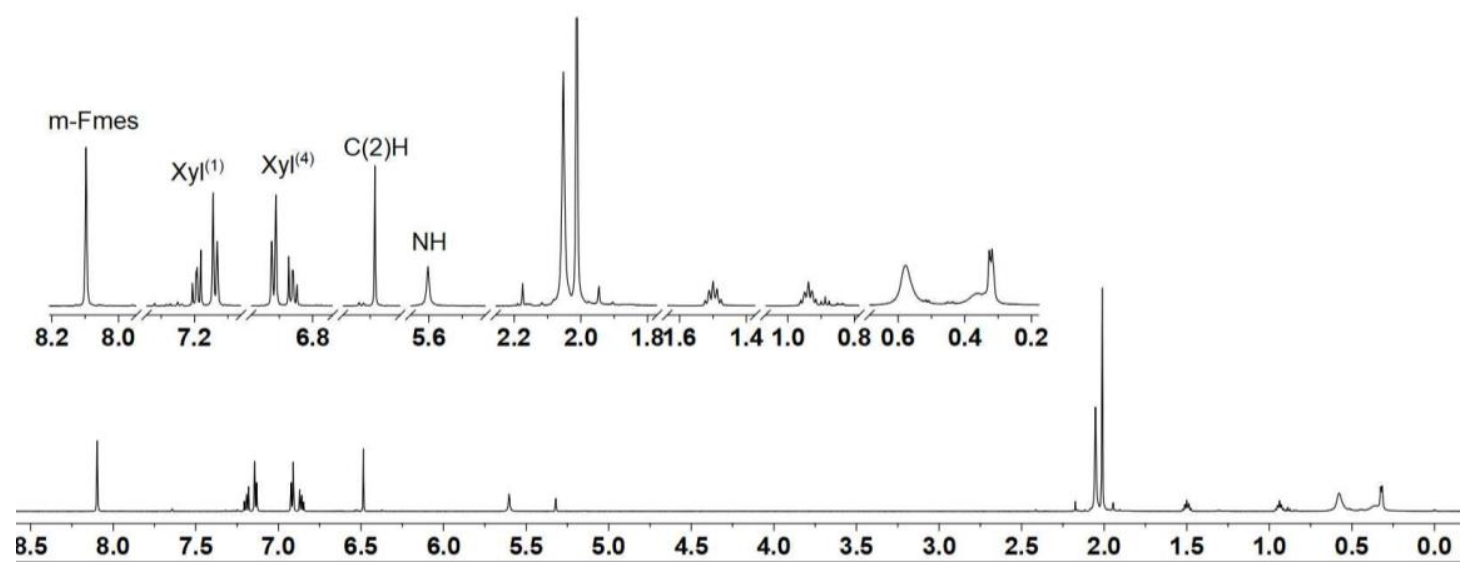

Figure S127. ${ }^{1} \mathrm{H}$ NMR ( $600 \mathrm{MHz}$, methylene chloride- $\left.d_{2}, 299 \mathrm{~K}\right)$ spectrum of compound $24 \mathrm{e}$.

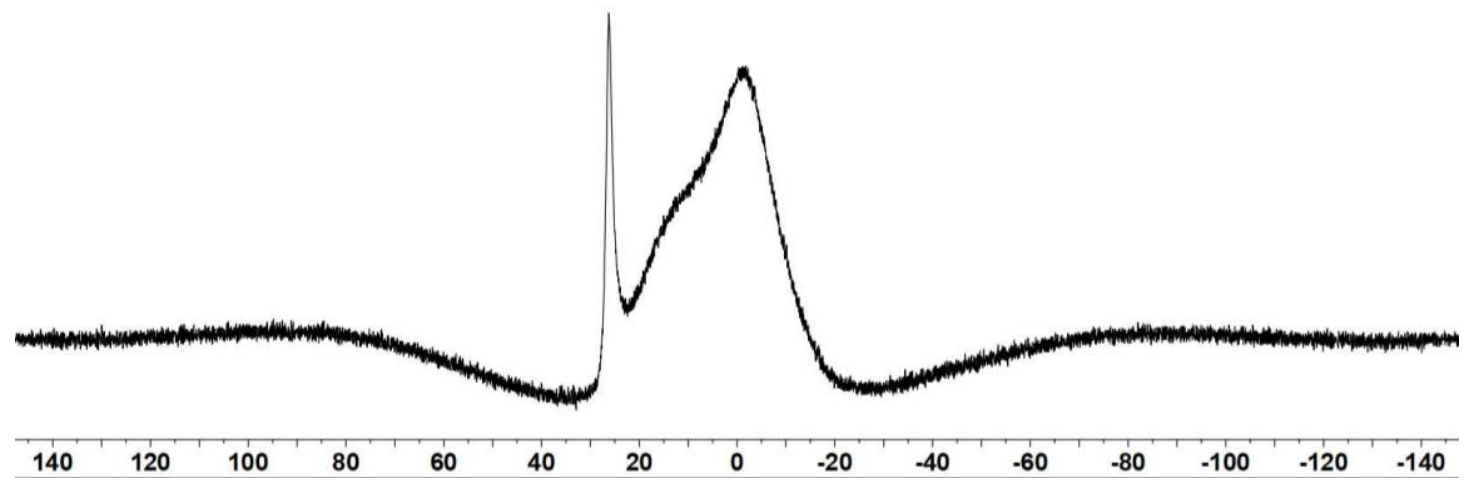

Figure S128. ${ }^{11} \mathrm{~B}\left\{{ }^{1} \mathrm{H}\right\} \mathrm{NMR}\left(192 \mathrm{MHz}\right.$, methylene chloride- $\left.d_{2}, 299 \mathrm{~K}\right)$ spectrum of compound 24e. 


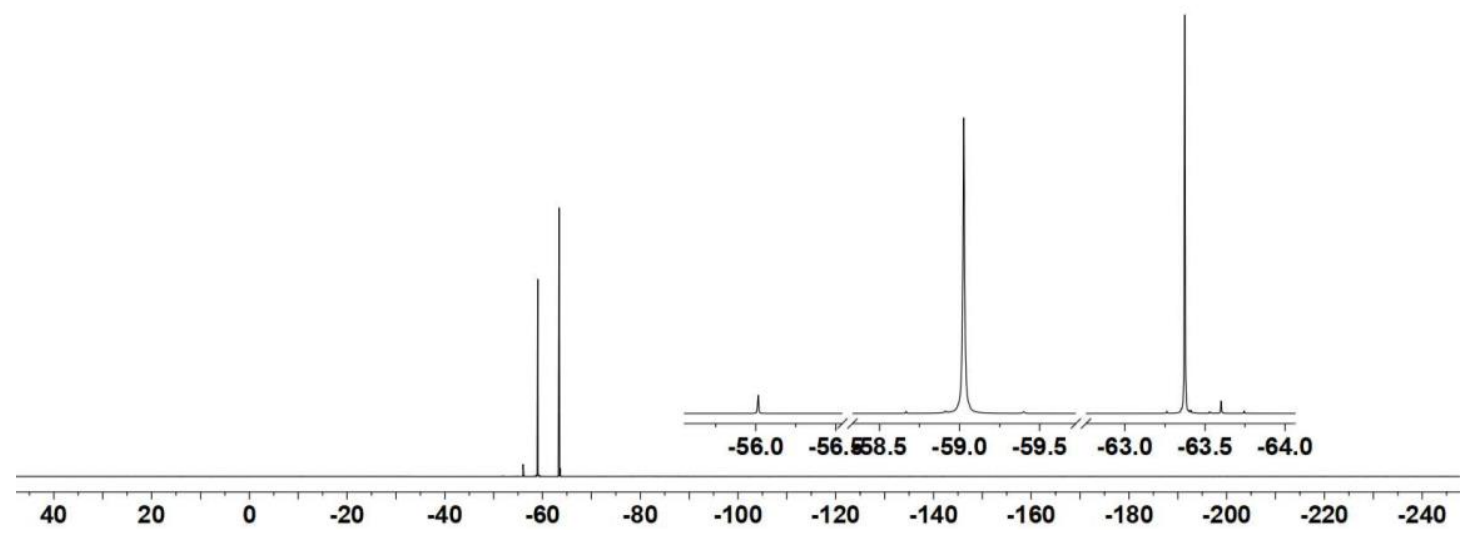

Figure S129. ${ }^{19} \mathrm{~F}$ NMR (564 MHz, methylene chloride- $d_{2}, 299 \mathrm{~K}$ ) spectrum of compound 24e.
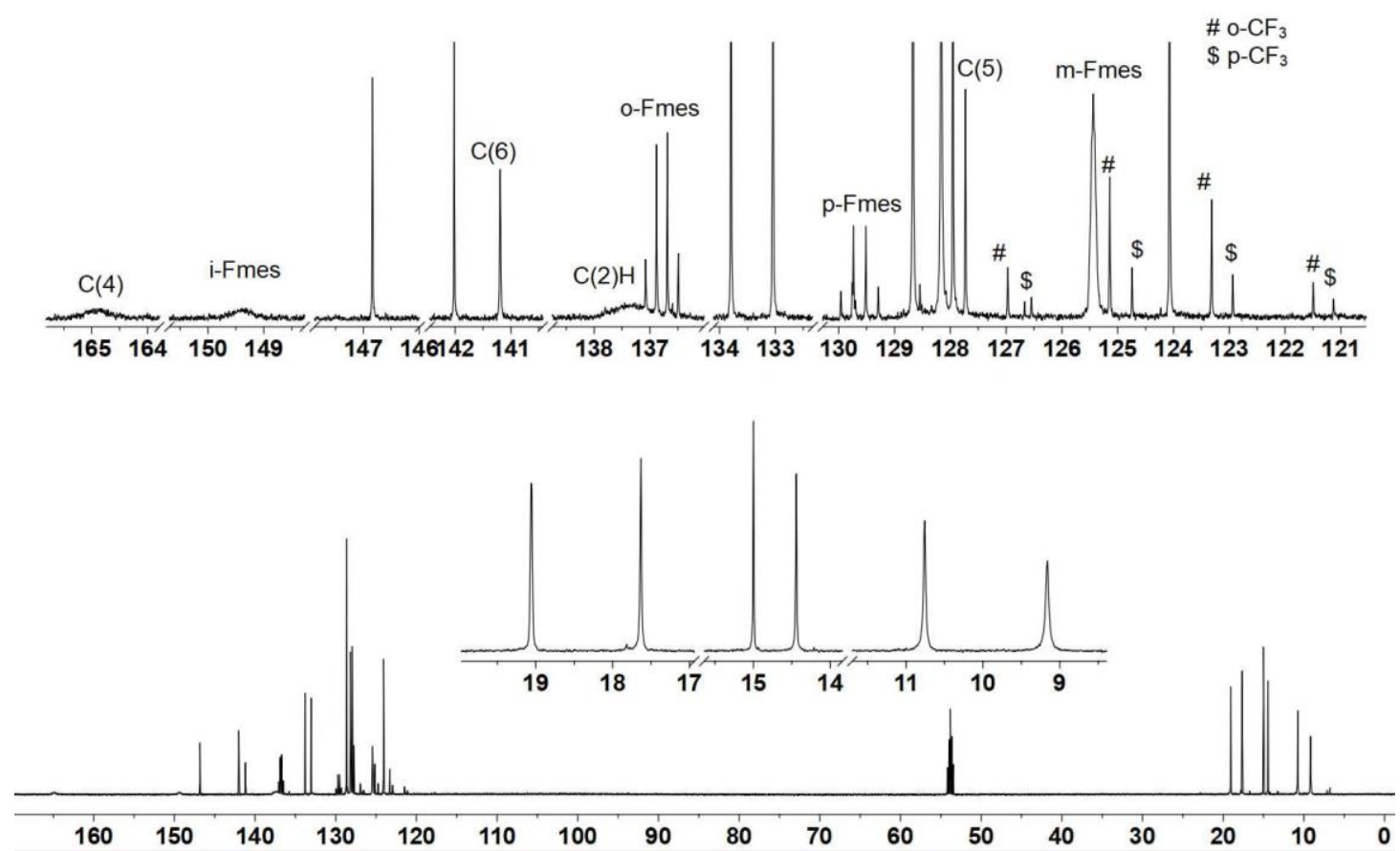

Figure $S 130 .{ }^{13} \mathrm{C}\left\{{ }^{1} \mathrm{H}\right\} \mathrm{NMR}\left(151 \mathrm{MHz}\right.$, methylene chloride- $d_{2}, 299 \mathrm{~K}$ ) spectrum of compound $24 \mathrm{e}$.

The crystal suitable for X-ray diffraction analysis was obtained from the solution of compound 24e in pentane at $-35^{\circ} \mathrm{C}$.

X-ray crystal structure analysis of compound 24e (erk9578): A pale yellow plate-like specimen of $\mathrm{C}_{40} \mathrm{H}_{44} \mathrm{BF}_{9} \mathrm{~N}_{2}$, approximate dimensions $0.040 \mathrm{~mm} \times 0.080 \mathrm{~mm} \times 0.100 \mathrm{~mm}$, was used for the X-ray crystallographic analysis. The X-ray intensity data were measured. A total of 1642 frames were collected. The total exposure time was 21.79 hours. The frames were integrated with the Bruker SAINT software package using a wide-frame algorithm. The integration of the data using a triclinic unit cell yielded a total of 29287 reflections to a maximum $\theta$ angle of $66.67^{\circ}$ ( $0.84 \AA$ A resolution), of which 6493 were independent (average redundancy 4.511 , completeness $=98.0 \%, R_{\text {int }}=10.13 \%$, $\left.\mathrm{R}_{\text {sig }}=10.40 \%\right)$ and $4026(62.01 \%)$ were greater than $2 \sigma\left(F^{2}\right)$. The final cell constants of $\underline{a}=8.6311(7)$ $\AA, \underline{b}=14.6478(12) \AA, \underline{c}=15.7274(12) \AA, \alpha=109.702(5)^{\circ}, \beta=92.143(5)^{\circ}, \gamma=92.957(6)^{\circ}$, volume = $1866.3(3) \AA^{3}$, are based upon the refinement of the XYZ-centroids of 3062 reflections above $20 \sigma(I)$ with $5.979^{\circ}<2 \theta<124.7^{\circ}$. Data were corrected for absorption effects using the multi-scan method 
(SADABS). The ratio of minimum to maximum apparent transmission was 0.778 . The calculated minimum and maximum transmission coefficients (based on crystal size) are 0.9140 and 0.9640 . The structure was solved and refined using the Bruker SHELXTL Software Package, using the space group $P-1$, with $Z=2$ for the formula unit, $\mathrm{C}_{40} \mathrm{H}_{44} \mathrm{BF}_{9} \mathrm{~N}_{2}$. The final anisotropic full-matrix leastsquares refinement on $\mathrm{F}^{2}$ with 528 variables converged at $\mathrm{R} 1=6.15 \%$, for the observed data and $W R 2=16.72 \%$ for all data. The goodness-of-fit was 1.041. The largest peak in the final difference electron density synthesis was $0.298 \mathrm{e}^{-} / \AA^{3}$ and the largest hole was $-0.263 \mathrm{e}^{-} / \AA^{3}$ with an RMS deviation of $0.062 \mathrm{e}^{-} / \AA^{3}$. On the basis of the final model, the calculated density was $1.307 \mathrm{~g} / \mathrm{cm}^{3}$ and $\mathrm{F}(000), 768 \mathrm{e}$. The hydrogen at $\mathrm{N} 1$ atom was refined freely. CCDC number: 2041299.

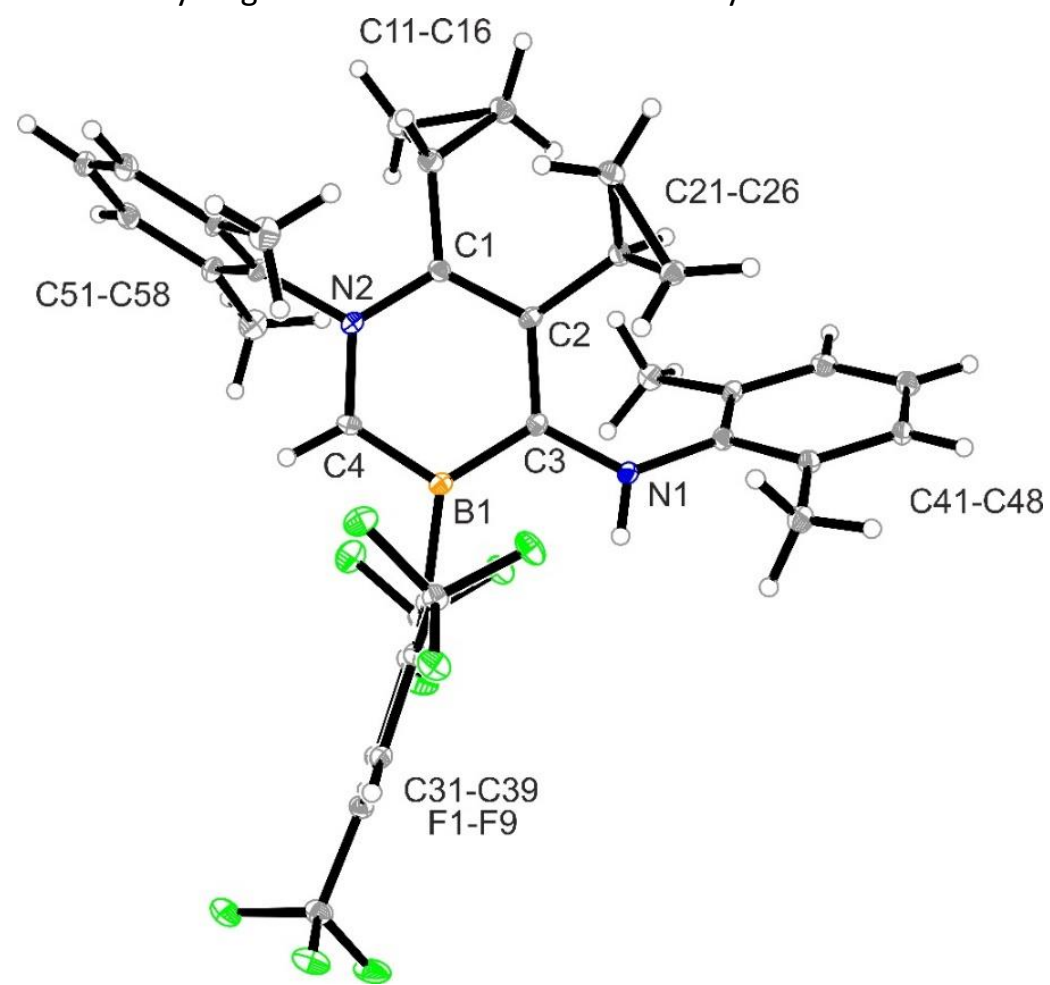

Figure S131. Crystal structure of compound 24e (thermal ellipsoids are set at 15\% probability).

\section{Preparation of the azaborinine derivative 25}

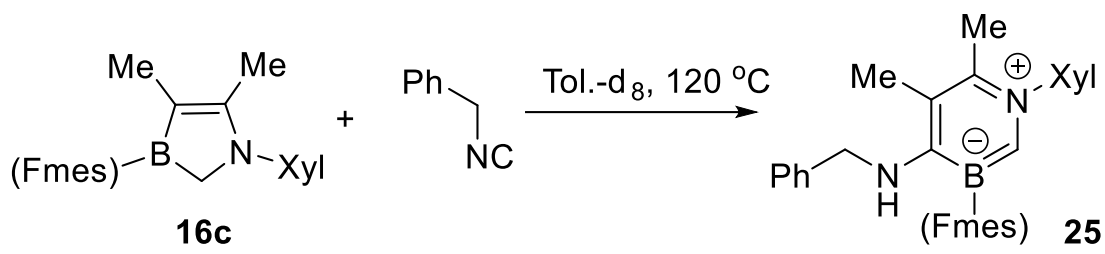

\section{Scheme S37.}

At room temperature, (isocyanomethyl)benzene $(17.6 \mathrm{mg}, 0.15 \mathrm{mmol}, 1$ eq.) was added to the solution of the azaborole $16 \mathrm{c}\left(62 \mathrm{mg}, 0.15 \mathrm{mmol}, 1 \mathrm{eq}\right.$.) in $\mathrm{d}_{8}$-toluene $(1 \mathrm{~mL})$ under an argon atmosphere in a J. Young tube. The resulting solution was stored at $120^{\circ} \mathrm{C}$ overnight. Then all volatiles were removed in vacuo. Subsequently, the residue was dissolved in pentane $(1 \mathrm{~mL})$ and stored at $-35{ }^{\circ} \mathrm{C}$ to finally give compound 25 as a pale-yellow solid (68 $\mathrm{mg}, 76 \%$ yield). HRMS for $\mathrm{C}_{30} \mathrm{H}_{27} \mathrm{BF}_{9} \mathrm{~N}_{2}{ }^{+}[\mathrm{M}+\mathrm{H}]^{+}$: calc. 597.2123; found: 597.2118 . 
${ }^{1} \mathrm{H}$ NMR (600 MHz, methylene chloride- $d_{2}, 299 \mathrm{~K}$ ): $\delta=8.05$ (s, $2 \mathrm{H}, m$-Fmes), $7.30(\mathrm{~m}, 2 \mathrm{H}, m$-Ph), $7.26(\mathrm{~m}, 1 \mathrm{H}, p-\mathrm{Ph}), 7.21(\mathrm{~m}, 2 \mathrm{H}, o-\mathrm{Ph}), 7.19(\mathrm{~m}, 1 \mathrm{H}, p-\mathrm{Xyl}), 7.14(\mathrm{~m}, 2 \mathrm{H}, m-\mathrm{Xyl}), 6.40(\mathrm{~s}, 1 \mathrm{H}, \mathrm{C}(2) \mathrm{H})$, $\left.4.43\left(\mathrm{t},{ }^{3}\right)_{\mathrm{HH}}=5.1 \mathrm{~Hz}, 1 \mathrm{H}, \mathrm{NH}\right), 3.97\left(\mathrm{~d},{ }^{3}{ }_{\mathrm{HH}}=5.1 \mathrm{~Hz}, 2 \mathrm{H}, \mathrm{CH}_{2}\right), 2.13\left(\mathrm{~s}, 3 \mathrm{H}, \mathrm{CH}_{3}{ }^{(5)}\right), 2.07\left(\mathrm{~s}, 3 \mathrm{H}, \mathrm{CH}_{3}{ }^{(6)}\right)$, $1.98\left(\mathrm{~s}, 6 \mathrm{H}, \mathrm{o}-\mathrm{CH}_{3} \mathrm{XY}^{\prime}\right)$.

${ }^{13} \mathrm{C}\left\{{ }^{1} \mathrm{H}\right\}$ NMR (151 MHz, methylene chloride- $\left.d_{2}, 299 \mathrm{~K}\right): \delta=163.0(\mathrm{br}, \mathrm{C}(4)), 153.8$ (br, $\left.i-\mathrm{Fmes}\right), 146.4$ (i-Xyl), $140.2(i-\mathrm{Ph}), 138.1$ (br, C(2)H), 135.7 (q, ${ }^{2} \mathrm{JFC}_{\mathrm{FC}}=28.6 \mathrm{~Hz}, o$-Fmes), 134.3 (m-Xyl), $133.5(\mathrm{C}(6))$, $128.92\left(q,{ }^{2} \mathrm{JFC}_{\mathrm{FC}} 33.9 \mathrm{~Hz}, p\right.$-Fmes), $128.91(m-\mathrm{Ph}), 128.7$ (m-Xyl), 128.5 (o-Ph), 128.3 ( $p$-Xyl), 127.8 ( $p$-Ph), 124.9 (br, $m$-Fmes), 124.5 (q, ${ }^{1} J_{\mathrm{FC}}=276.6 \mathrm{~Hz}, o-\mathrm{CF}_{3}{ }^{\mathrm{Fmes}}$ ), 123.9 (q, ${ }^{1} \mathrm{~J}_{\mathrm{FC}}=271.3 \mathrm{~Hz}, p$-CF ${ }^{\mathrm{Fmes}}$ ), $116.3(\mathrm{C}(5)), 51.4\left(\mathrm{CH}_{2}\right), 17.4\left(\mathrm{CH}_{3}{ }^{(6)}\right), 17.0\left(0-\mathrm{CH}_{3}{ }^{\mathrm{Xy}}\right), 14.0\left(\mathrm{CH}_{3}{ }^{(5)}\right)$.

${ }^{11} \mathrm{~B}\left\{{ }^{1} \mathrm{H}\right\}$ NMR $\left(192 \mathrm{MHz}\right.$, methylene chloride- $\left.d_{2}, 299 \mathrm{~K}\right): \delta=22.9\left(\mathrm{v}_{1 / 2} \approx 300 \mathrm{~Hz}\right)$.

${ }^{19} \mathrm{~F} \mathrm{NMR}\left(564 \mathrm{MHz}\right.$, methylene chloride- $\left.d_{2}, 299 \mathrm{~K}\right): \delta=-57.9\left(\mathrm{~s}, 2 \mathrm{~F}, o-\mathrm{CF}_{3}{ }^{\mathrm{Fmes}}\right),-63.2\left(\mathrm{~s}, 1 \mathrm{~F}, o-\mathrm{CF}_{3}{ }^{\mathrm{Fmes}}\right)$.

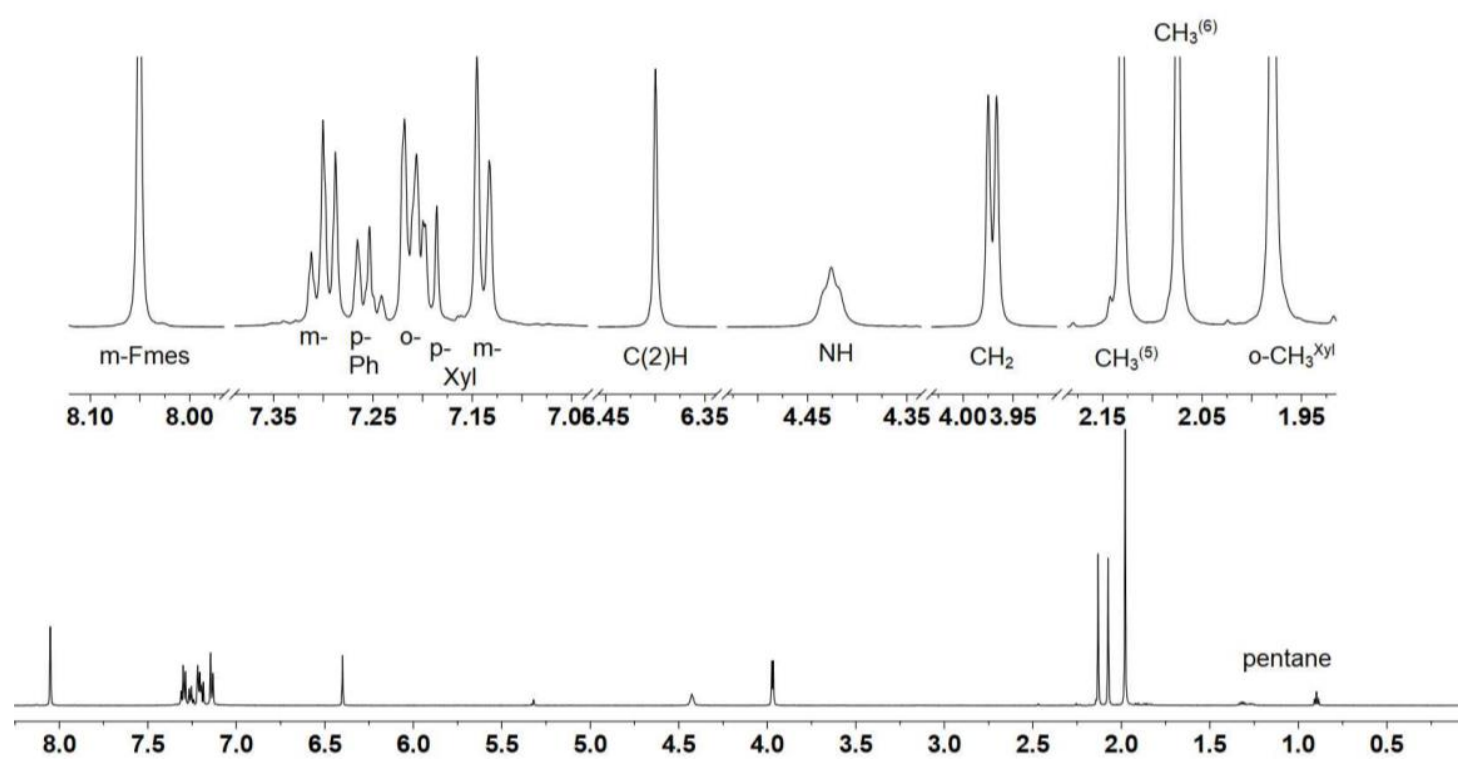

Figure S132. ${ }^{1} \mathrm{H}$ NMR (600 MHz, methylene chloride- $\left.d_{2}, 299 \mathrm{~K}\right)$ spectrum of compound 25.

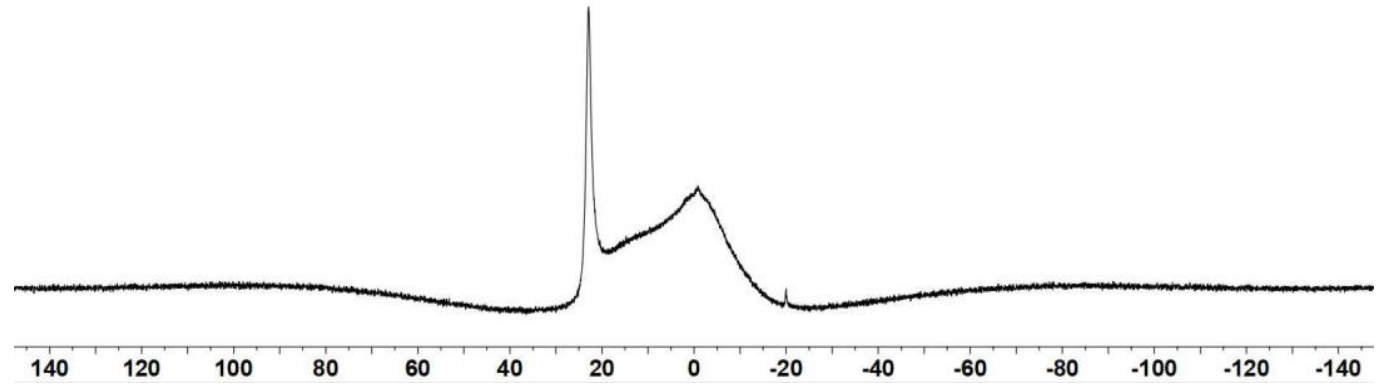

Figure S133. ${ }^{11} \mathrm{~B}\left\{{ }^{1} \mathrm{H}\right\}$ NMR (192 MHz, methylene chloride- $\left.d_{2}, 299 \mathrm{~K}\right)$ spectrum of compound 25.

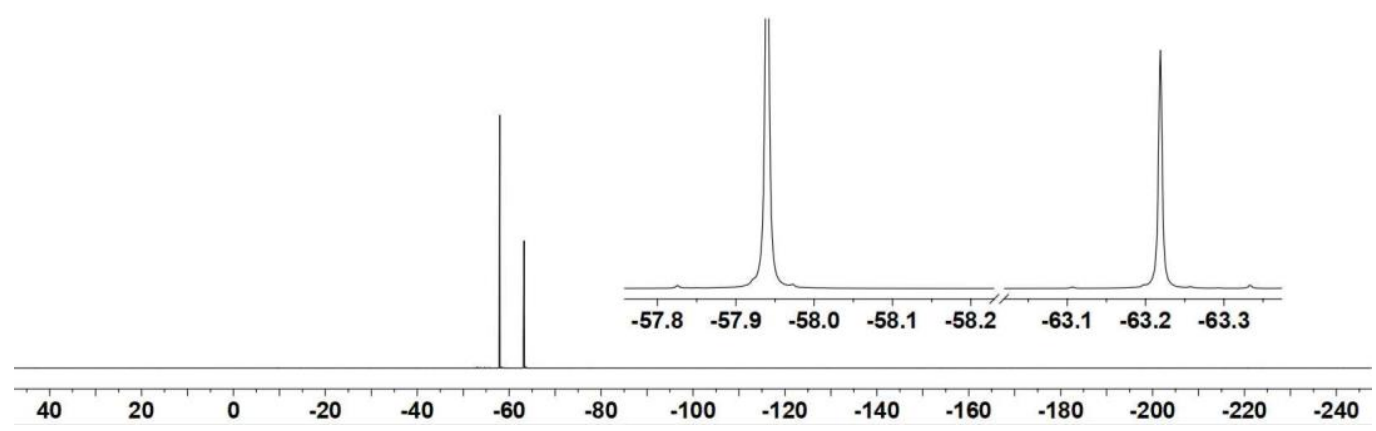

Figure S134. ${ }^{19} \mathrm{~F}$ NMR ( $564 \mathrm{MHz}$, methylene chloride- $d_{2}, 299 \mathrm{~K}$ ) spectrum of compound 25. 

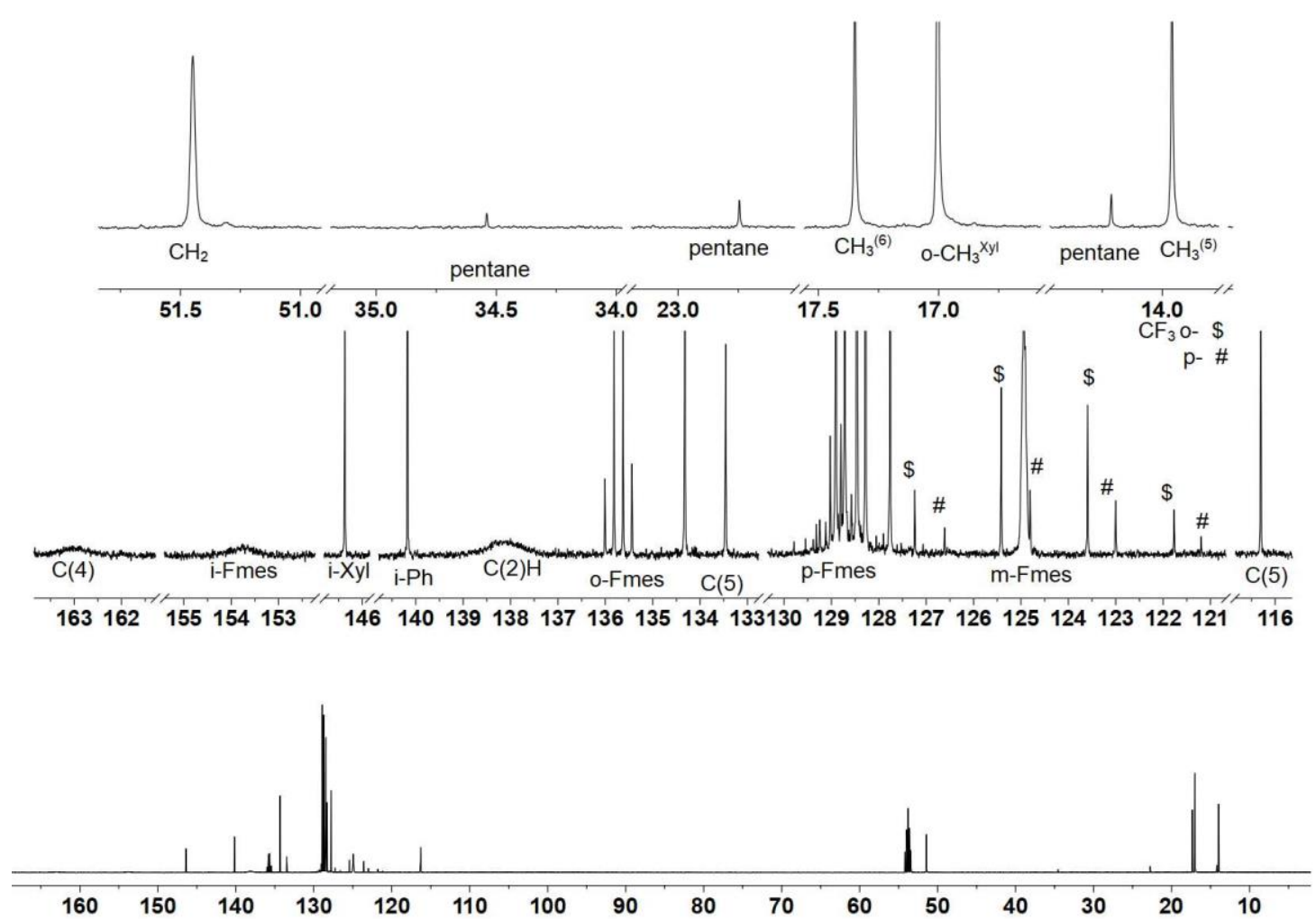

Figure 135. ${ }^{13} \mathrm{C}\left\{{ }^{1} \mathrm{H}\right\}$ NMR (151 MHz, methylene chloride- $\left.d_{2}, 299 \mathrm{~K}\right)$ spectrum of compound 25.

The crystal suitable for X-ray diffraction analysis was obtained from the solution of compound $\mathbf{2 5}$ in pentane at $-35^{\circ} \mathrm{C}$.

X-ray crystal structure analysis of compound 25 (erk9694): A pale yellow prism-like specimen of $\mathrm{C}_{30} \mathrm{H}_{26} \mathrm{BF}_{9} \mathrm{~N}_{2}$, approximate dimensions $0.046 \mathrm{~mm} \times 0.100 \mathrm{~mm} \times 0.153 \mathrm{~mm}$, was used for the X-ray crystallographic analysis. The X-ray intensity data were measured. A total of 990 frames were collected. The total exposure time was 22.74 hours. The frames were integrated with the Bruker SAINT software package using a wide-frame algorithm. The integration of the data using a monoclinic unit cell yielded a total of 35855 reflections to a maximum $\theta$ angle of $66.94^{\circ}$ ( $0.84 \AA$ resolution), of which 4886 were independent (average redundancy 7.338 , completeness $=99.6 \%$, $\left.\mathrm{R}_{\text {int }}=5.72 \%, \mathrm{R}_{\text {sig }}=3.14 \%\right)$ and $3957(80.99 \%)$ were greater than $2 \sigma\left(\mathrm{F}^{2}\right)$. The final cell constants of a $=13.7751(3) \AA, \underline{b}=11.5702(2) \AA, \underline{c}=17.4052(4) \AA, \beta=97.6090(10)^{\circ}$, volume $=2749.63(10) \AA^{3}$, are based upon the refinement of the XYZ-centroids of 9940 reflections above $20 \sigma(I)$ with $9.203^{\circ}<2 \theta$ $<133.6^{\circ}$. Data were corrected for absorption effects using the multi-scan method (SADABS). The ratio of minimum to maximum apparent transmission was 0.882 . The calculated minimum and maximum transmission coefficients (based on crystal size) are 0.8490 and 0.9510 .

The structure was solved and refined using the Bruker SHELXTL Software Package, using the space group $P 2_{1} / c$, with $Z=4$ for the formula unit, $\mathrm{C}_{30} \mathrm{H}_{26} \mathrm{BF}_{9} \mathrm{~N}_{2}$. The final anisotropic full-matrix leastsquares refinement on $\mathrm{F}^{2}$ with 387 variables converged at $\mathrm{R} 1=4.22 \%$, for the observed data and $W R 2=9.98 \%$ for all data. The goodness-of-fit was 1.072 . The largest peak in the final difference electron density synthesis was $0.235 \mathrm{e}^{-} / \AA^{3}$ and the largest hole was $-0.208 \mathrm{e}^{-} / \AA^{3}$ with an RMS deviation of $0.048 \mathrm{e}^{-} / \AA^{3}$. On the basis of the final model, the calculated density was $1.441 \mathrm{~g} / \mathrm{cm}^{3}$ and $\mathrm{F}(000), 1224 \mathrm{e}^{-}$. The hydrogen at $\mathrm{N} 1$ atom was refined freely. CCDC number: 2041300. 


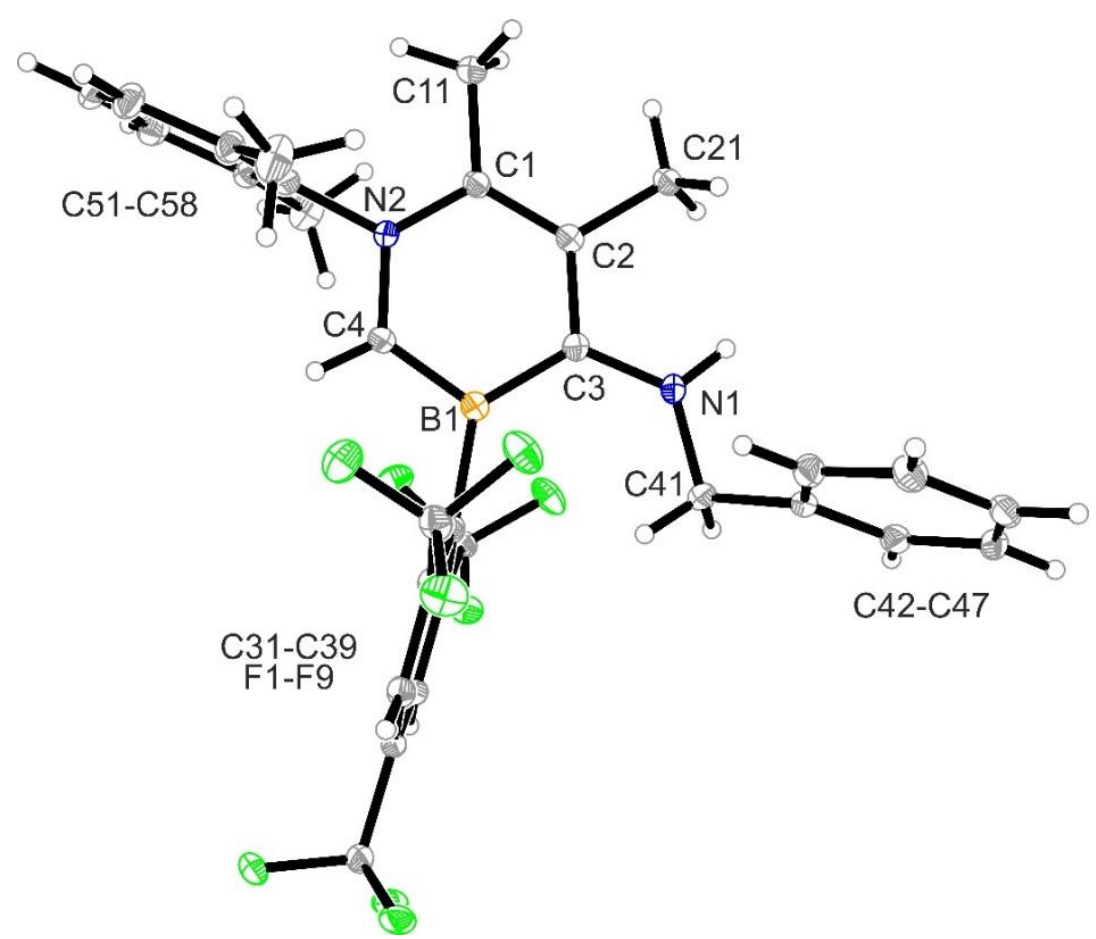

Figure S136. Crystal structure of compound $\mathbf{2 5}$ (thermal ellipsoids are set at 30\% probability).

\section{Preparation of the azaborinine derivative 26}

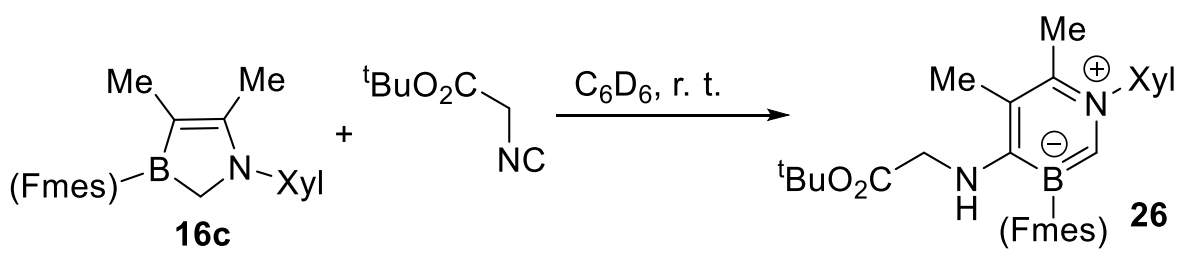

\section{Scheme S38.}

At room temperature, the azaborole $16 \mathrm{c}(62 \mathrm{mg}, 0.15 \mathrm{mmol}, 1$ eq.) was added to the solution of tert-butyl 2-isocyanoacetate ( $35.1 \mathrm{mg}, 0.3 \mathrm{mmol}, 2$ eq.) in $\mathrm{C}_{6} \mathrm{D}_{6}(2 \mathrm{~mL})$ under an argon atmosphere in a J. Young tube. The resulting solution was stored at room temperature for 7 days. Volatiles were removed in vacuo, the residue was dissolved in heptane $(1 \mathrm{~mL})$ and stored at room temperature for 15 days to finally give the products as a yellow solid ( $38 \mathrm{mg}, 31 \%$ yield).

HRMS for $\mathrm{C}_{29} \mathrm{H}_{30} \mathrm{BF}_{9} \mathrm{~N}_{2} \mathrm{O}_{2} \mathrm{Na}^{+}$, [M+Na] $]^{+}$: calc. 643.2154; Found: 643.2146.

${ }^{1} \mathrm{H}$ NMR $\left(600 \mathrm{MHz}\right.$, methylene chloride- $\left.d_{2}, 299 \mathrm{~K}\right): \delta=8.08(\mathrm{~s}, 2 \mathrm{H}, m$-Fmes), $7.18(\mathrm{~m}, 1 \mathrm{H}, p$-Xyl), $\left.7.12(\mathrm{~m}, 2 \mathrm{H}, m-\mathrm{Xyl}), 6.36(\mathrm{~s}, 1 \mathrm{H}, \mathrm{C}(2) \mathrm{H}), 4.98\left(\mathrm{t},{ }^{3}\right)_{\mathrm{HH}}=4.9 \mathrm{~Hz}, 1 \mathrm{H}, \mathrm{NH}\right), 3.43\left(\mathrm{~d},{ }^{3} \mathrm{H}_{\mathrm{HH}}=4.9 \mathrm{~Hz}, 2 \mathrm{H}\right.$, $\left.\mathrm{CH}_{2}\right), 2.22\left(\mathrm{~s}, 3 \mathrm{H}, \mathrm{CH}_{3}{ }^{(5)}\right), 2.06\left(\mathrm{~s}, 3 \mathrm{H}, \mathrm{CH}_{3}{ }^{(6)}\right), 1.94\left(\mathrm{~s}, 6 \mathrm{H}, \mathrm{o}-\mathrm{CH}_{3}{ }^{\mathrm{Xyl}}\right), 1.39\left(\mathrm{~s}, 9 \mathrm{H}, \mathrm{CH}_{3}{ }^{\mathrm{tBu}}\right)$.

${ }^{13} \mathrm{C}\left\{{ }^{1} \mathrm{H}\right\}$ NMR (151 MHz, methylene chloride- $\left.d_{2}, 299 \mathrm{~K}\right): \delta=170.7(\mathrm{C}=0), 161.9(\mathrm{br}, \mathrm{C}(4)), 153.3(\mathrm{br}$, $i$-Fmes), 146.3 (i-Xyl), 138.3 (br, C(2)H), 135.8 (q, ${ }^{2} \mathrm{~J}_{\mathrm{FC}}=28.7 \mathrm{~Hz}, o$-Fmes), 134.3 (o-Xyl), $133.6(\mathrm{C}(6))$, $129.1\left(\mathrm{q},{ }^{2} \mathrm{~J}_{\mathrm{FC}}=33.8 \mathrm{~Hz}, p\right.$-Fmes), 128.7 (m-Xyl), 128.3 ( $p$-Xyl), 125.0 (br, $m$-Fmes), 124.4 (q, ${ }^{1} \mathrm{JFC}_{\mathrm{FC}}=$ $\left.274.6 \mathrm{~Hz}, o-\mathrm{CF}_{3}{ }^{\mathrm{Fmes}}\right), 123.9\left(\mathrm{q},{ }^{1} \mathrm{~J}_{\mathrm{FC}}=272.0 \mathrm{~Hz}, p-\mathrm{CF}_{3}{ }^{\mathrm{Fmes}}\right), 117.1(\mathrm{C}(5)), 82.2\left(\mathrm{C}^{\mathrm{tBu}}\right), 48.4\left(\mathrm{CH}_{2}\right), 28.1$ $\left(\mathrm{CH}_{3}{ }^{\mathrm{t}}{ }^{\mathrm{Bu}}\right), 17.3\left(\mathrm{CH}_{3}{ }^{(6)}\right), 17.0\left(0-\mathrm{CH}_{3}{ }^{\mathrm{Xy}}\right), 13.8\left(\mathrm{CH}_{3}{ }^{(5)}\right)$.

${ }^{11} B\left\{{ }^{1} H\right\}$ NMR (192 MHz, methylene chloride- $\left.d_{2}, 299 \mathrm{~K}\right): \delta=19.5\left(\mathrm{v}_{1 / 2} \approx 310 \mathrm{~Hz}\right)$.

${ }^{19} \mathrm{~F} \mathrm{NMR}\left(564 \mathrm{MHz}\right.$, methylene chloride- $\left.d_{2}, 299 \mathrm{~K}\right): \delta=-58.2\left(\mathrm{~s}, 2 \mathrm{~F}, o-\mathrm{CF}_{3}{ }^{\text {Fmes }}\right),-63.3\left(\mathrm{~s}, 1 \mathrm{~F}, p-\mathrm{CF}_{3}{ }^{\text {Fmes }}\right.$ ). 


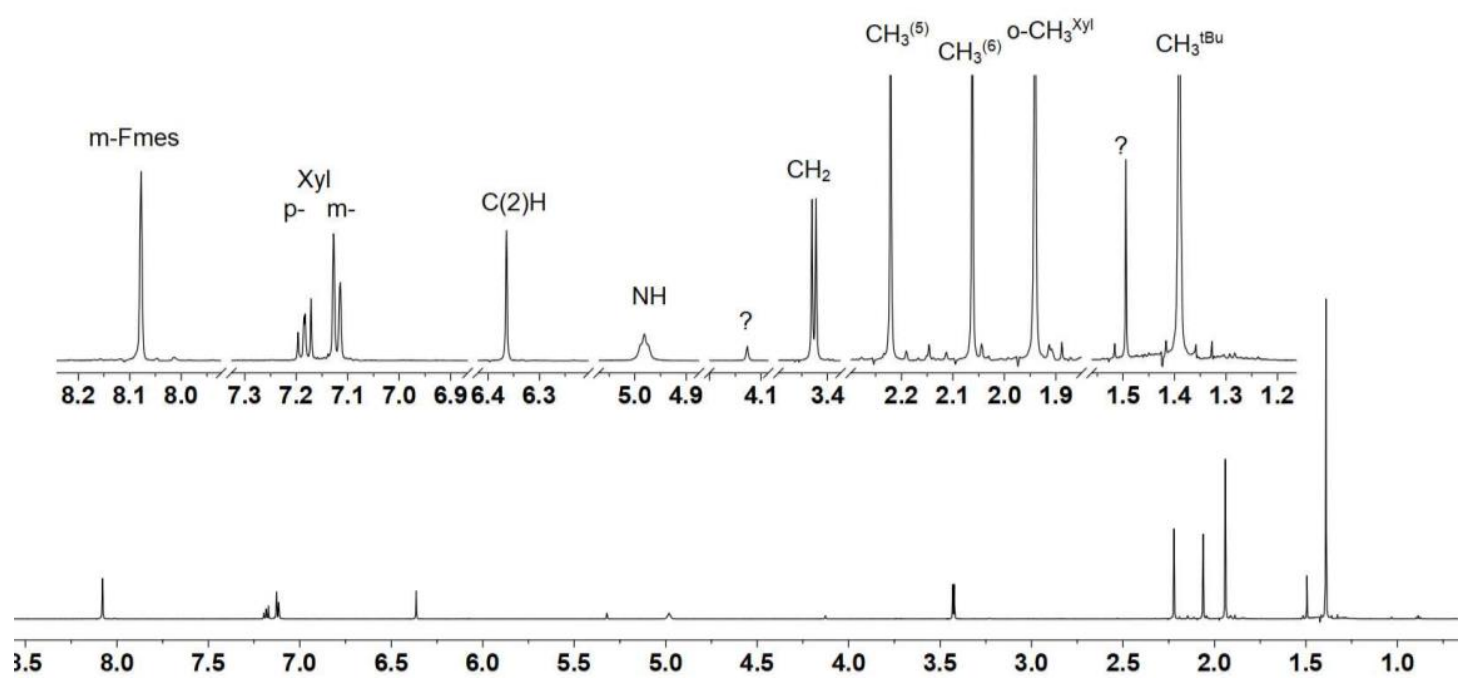

Figure S137. ${ }^{1} \mathrm{H}$ NMR (600 MHz, methylene chloride- $\left.d_{2}, 299 \mathrm{~K}\right)$ spectrum of compound 26.

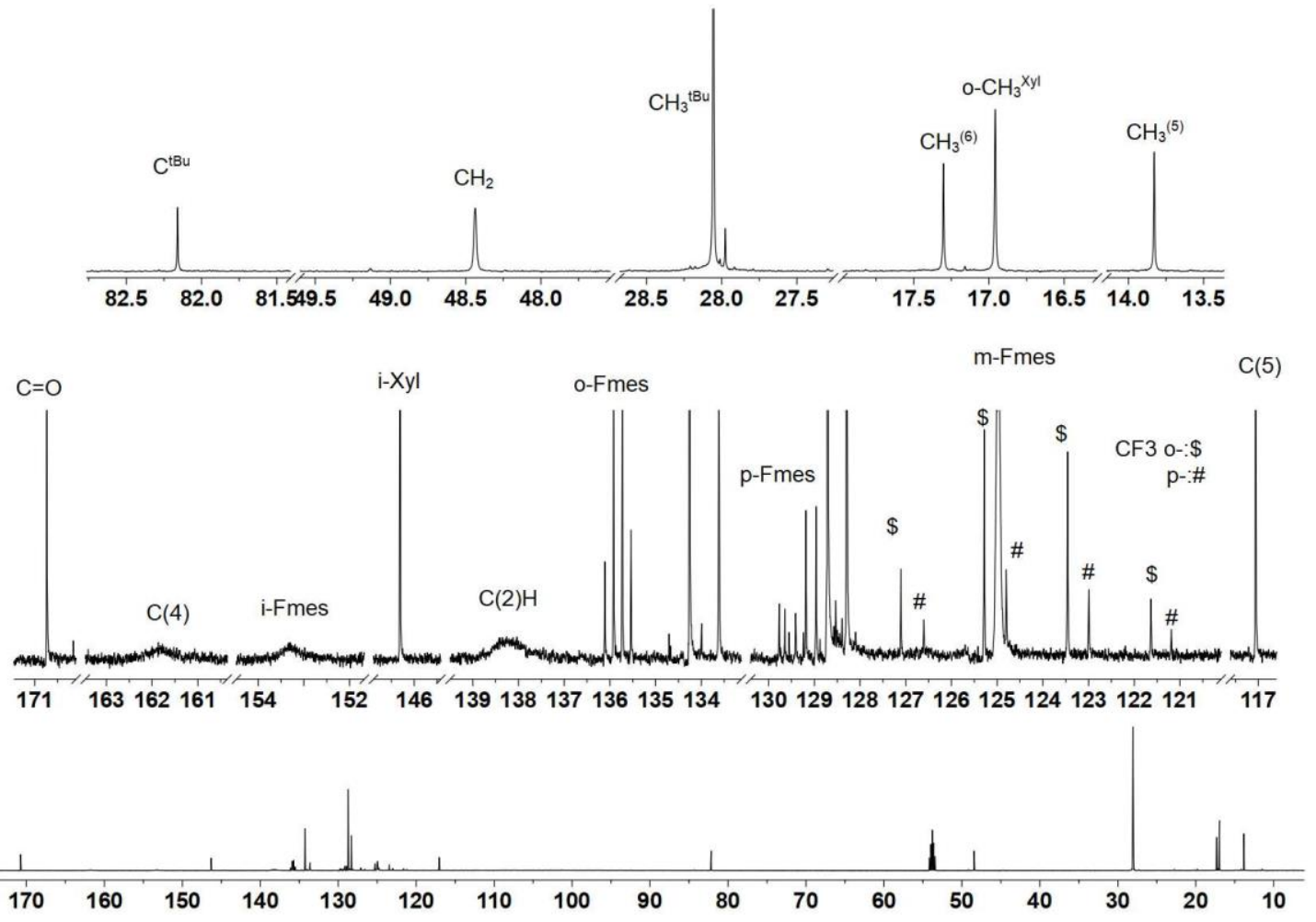

Figure S138. ${ }^{13} \mathrm{C}\left\{{ }^{1} \mathrm{H}\right\} \mathrm{NMR}\left(151 \mathrm{MHz}\right.$, methylene chloride- $\left.d_{2}, 299 \mathrm{~K}\right)$ spectrum of compound 26.

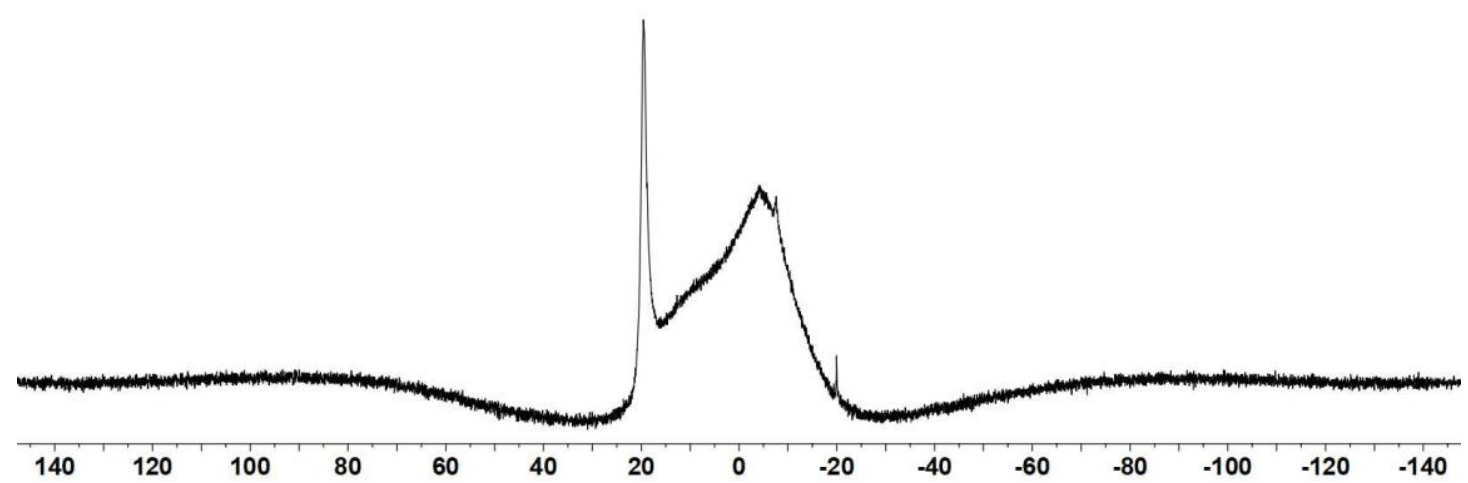

Figure S139. ${ }^{11} \mathrm{~B}\left\{{ }^{1} \mathrm{H}\right\}$ NMR (192 MHz, methylene chloride- $d_{2}, 299 \mathrm{~K}$ ) spectrum of compound 26. 


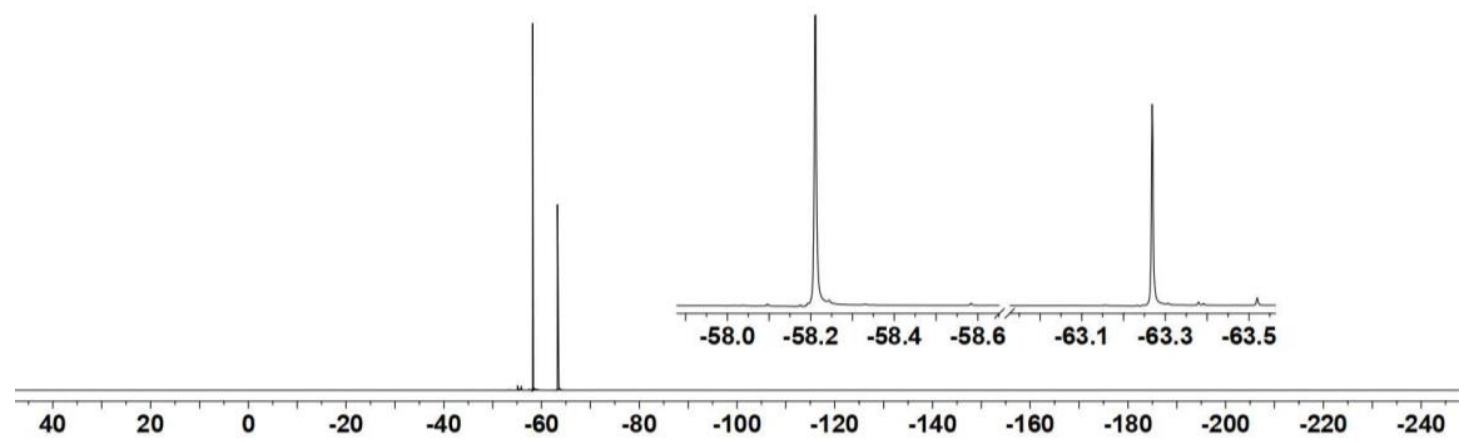

Figure S140. ${ }^{19} \mathrm{~F}$ NMR (564 MHz, methylene chloride- $d_{2}, 299 \mathrm{~K}$ ) spectrum of compound 26.

The crystal suitable for X-ray diffraction analysis was obtained from the solution of compound $\mathbf{2 6}$ in heptane at room temperature.

X-ray crystal structure analysis of compound 26 (erk9641): A pale yellow prism-like specimen of $\mathrm{C}_{29} \mathrm{H}_{30} \mathrm{BF}_{9} \mathrm{~N}_{2} \mathrm{O}_{2}$, approximate dimensions $0.078 \mathrm{~mm} \times 0.105 \mathrm{~mm} \times 0.226 \mathrm{~mm}$, was used for the $\mathrm{X}$ ray crystallographic analysis. The X-ray intensity data were measured. A total of 1144 frames were collected. The total exposure time was 12.71 hours. The frames were integrated with the Bruker SAINT software package using a narrow-frame algorithm. The integration of the data using a triclinic unit cell yielded a total of 35028 reflections to a maximum $\theta$ angle of $27.47^{\circ}(0.77 \AA$ resolution), of which 6836 were independent (average redundancy 5.124, completeness $=99.3 \%$, $\left.R_{\text {int }}=3.27 \%, R_{\text {sig }}=2.22 \%\right)$ and $6230(91.14 \%)$ were greater than $2 \sigma\left(F^{2}\right)$. The final cell constants of $\underline{a}$ $=10.4043(3) \AA, \underline{b}=11.6812(3) \AA, \underline{c}=13.5156(3) \AA, \alpha=92.0810(10)^{\circ}, \beta=94.3730(10)^{\circ}, \gamma=$ $113.2720(10)^{\circ}$, volume $=1500.61(7) \AA^{3}$, are based upon the refinement of the XYZ-centroids of 9890 reflections above $20 \sigma(\mathrm{I})$ with $4.69^{\circ}<2 \theta<54.91^{\circ}$. Data were corrected for absorption effects using the multi-scan method (SADABS). The ratio of minimum to maximum apparent transmission was 0.971. The calculated minimum and maximum transmission coefficients (based on crystal size) are 0.9730 and 0.9900 . The structure was solved and refined using the Bruker SHELXTL Software Package, using the space group $P-1$, with $\mathrm{Z}=2$ for the formula unit, $\mathrm{C}_{29} \mathrm{H}_{30} \mathrm{BF}_{9} \mathrm{~N}_{2} \mathrm{O}_{2}$. The final anisotropic full-matrix least-squares refinement on $\mathrm{F}^{2}$ with 399 variables converged at $\mathrm{R} 1=4.12 \%$, for the observed data and wR2 $=9.60 \%$ for all data. The goodness-of-fit was 1.032. The largest peak in the final difference electron density synthesis was $0.385 \mathrm{e}^{-} / \AA^{3}$ and the largest hole was $-0.223 \mathrm{e}^{-}$ $/ \AA^{3}$ with an RMS deviation of $0.042 \mathrm{e}^{-} / \AA^{3}$. On the basis of the final model, the calculated density was $1.373 \mathrm{~g} / \mathrm{cm}^{3}$ and $\mathrm{F}(000), 640 \mathrm{e}$. The hydrogen at N1 atom was refined freely. CCDC number: 2041301. 


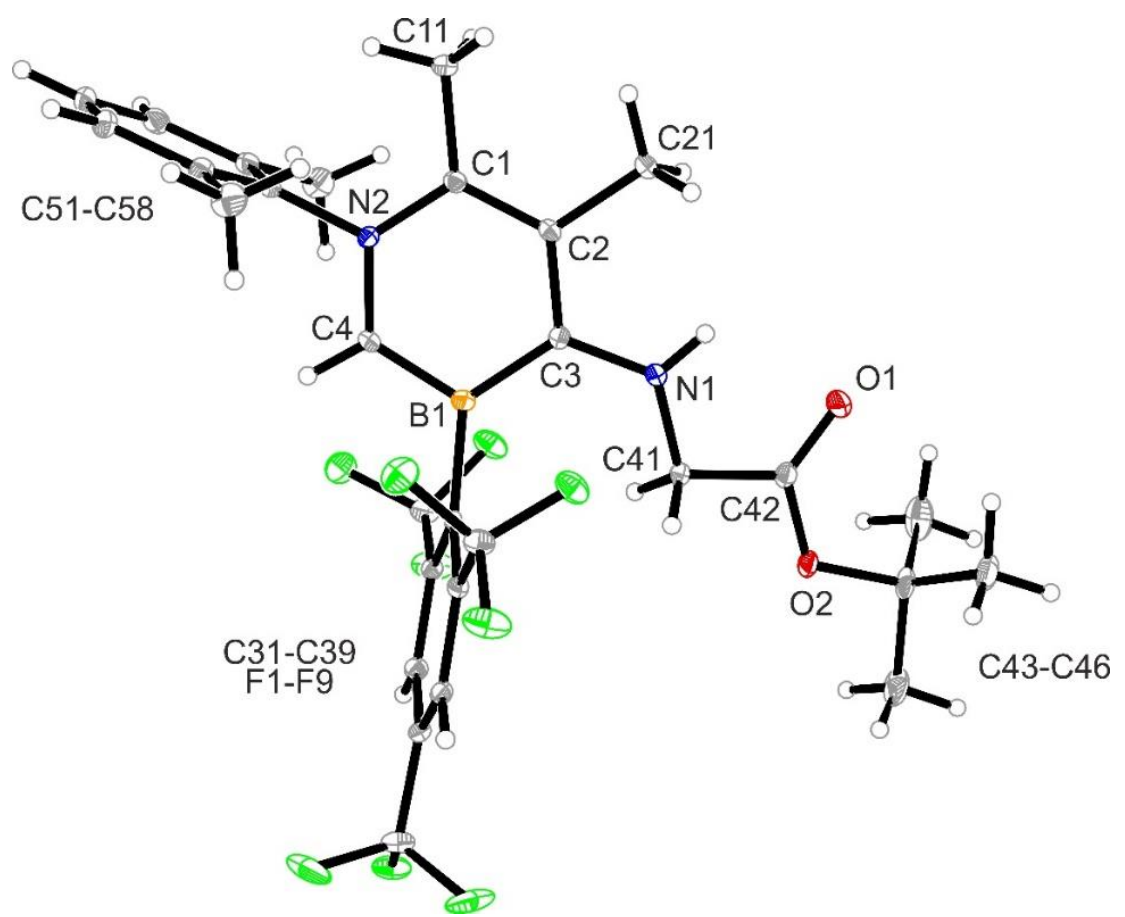

Figure S141. Crystal structure of compound $\mathbf{2 6}$ (thermal ellipsoids are set at 30\% probability).

\section{Preparation of azaborole derivative $16 \mathrm{~h}$}

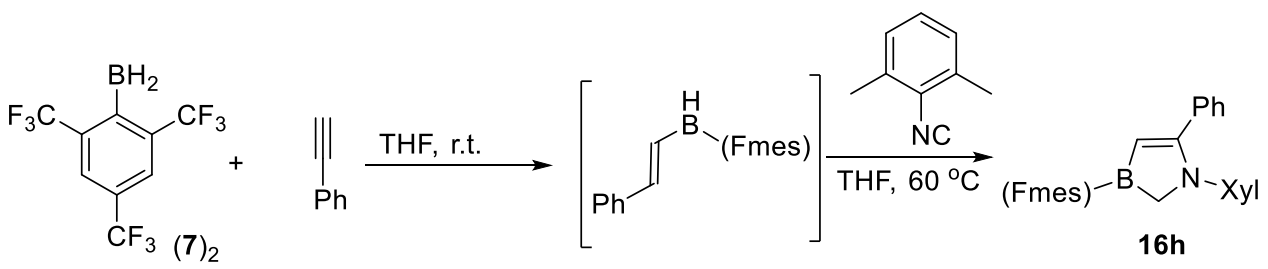

Scheme S39.

At room temperature, phenylacetylene (102 $\mathrm{mg}, 1 \mathrm{mmol}, 1$ eq.) was added to the solution of borane (7) $)_{2}(294 \mathrm{mg}, 1.0 \mathrm{mmol}, 1 \mathrm{eq}$.) in THF (10 mL) under an argon atmosphere in a Schlenk tube. The resulting mixture was stirred for $2 \mathrm{~h}$ at room temperature to give a colorless solution. Then 2,6dimethylphenyl isocyanide (131 mg, $1.0 \mathrm{mmol}, 1$ eq.) was added in one portion to give a yellow solution. The solution was stirred at $60^{\circ} \mathrm{C}$ overnight. Then all volatiles were removed in vacuo and the residue was purified by column chromatography at silica gel with pentane as eluent to give compound $16 \mathrm{~h}$ as a white solid ( $160 \mathrm{mg}, 30 \%$ yield).

HRMS for $\mathrm{C}_{26} \mathrm{H}_{22} \mathrm{BONF}_{9}{ }^{+}\left[\mathrm{M}+\mathrm{H}_{3} \mathrm{O}\right]^{+}$: calc. 546.1450; found: 546.1446 .

${ }^{1} \mathrm{H}$ NMR $\left(600 \mathrm{MHz}\right.$, methylene chloride- $\left.d_{2}, 299 \mathrm{~K}\right): \delta=8.14(\mathrm{~s}, 2 \mathrm{H}, m$-Fmes), $7.36(\mathrm{~m}, 2 \mathrm{H}, o-\mathrm{Ph}$ ), $7.31(\mathrm{~m}, 1 \mathrm{H}, p-\mathrm{Ph}), 7.24(\mathrm{~m}, 2 \mathrm{H}, m-\mathrm{Ph}), 7.08(\mathrm{~m}, 1 \mathrm{H}, p-\mathrm{Xyl}), 7.02(\mathrm{~m}, 2 \mathrm{H}, m-\mathrm{Xyl}), 5.62(\mathrm{~s}, 1 \mathrm{H}, \mathrm{CH}=)$, 3.77 (sep, $\left.J_{\mathrm{FH}}=2.5 \mathrm{~Hz}, 2 \mathrm{H}, \mathrm{CH}_{2}{ }^{\mathrm{NB}}\right), 2.15\left(\mathrm{~s}, 6 \mathrm{H}, o-\mathrm{CH}_{3}{ }^{\mathrm{Xyl}}\right)$.

${ }^{13} \mathrm{C}\left\{{ }^{1} \mathrm{H}\right\}$ NMR (151 MHz, methylene chloride- $\left.d_{2}, 299 \mathrm{~K}\right): \delta=182.2(\mathrm{CN}=), 146.4(\mathrm{br}, i-\mathrm{Fmes}), 141.7$ (i-Xyl), 137.0 (o-Xyl), $134.7(i-\mathrm{Ph}), 134.1$ (q, $\left.{ }^{2} J_{\mathrm{FC}}=30.9 \mathrm{~Hz}, o-\mathrm{Fmes}\right), 130.3$ (q, $\left.{ }^{2} J_{\mathrm{FC}}=34.1 \mathrm{~Hz}, p-\mathrm{Fmes}\right)$, 130.2 (p-Ph), 128.8 (m-Xyl), 128.6 (o-Ph), 128.3 (m-Ph), 127.9 (p-Xyl), 125.55 (br, m-Fmes), 124.3 $\left(q,{ }^{1} J_{\mathrm{FC}}=274.7 \mathrm{~Hz}, o-\mathrm{CF}_{3}{ }^{\mathrm{Fmes}}\right), 123.6\left(\mathrm{q},{ }^{1} \mathrm{~J}_{\mathrm{FC}}=272.1 \mathrm{~Hz}, p-\mathrm{CF}_{3}{ }^{\mathrm{Fmes}}\right), 109.1(\mathrm{CH}=), 58.2\left(\mathrm{br}, \mathrm{CH}_{2}{ }^{\mathrm{NB}}\right), 17.9$ $\left(o-\mathrm{CH}_{3}{ }^{\mathrm{Xy}}\right)$. 
${ }^{11} \mathrm{~B}\left\{{ }^{1} \mathrm{H}\right\}$ NMR (192 MHz, methylene chloride- $\left.d_{2}, 299 \mathrm{~K}\right): \delta=59.6\left(\mathrm{v}_{1 / 2} \approx 530 \mathrm{~Hz}\right)$.

${ }^{19} \mathrm{~F}$ NMR (564 MHz, methylene chloride- $\left.d_{2}, 299 \mathrm{~K}\right): \delta=-57.9\left(\mathrm{~s}, 2 \mathrm{~F}, o-\mathrm{CF}_{3}\right),-63.4\left(\mathrm{~s}, 1 \mathrm{~F}, p-\mathrm{CF}_{3}\right)$.

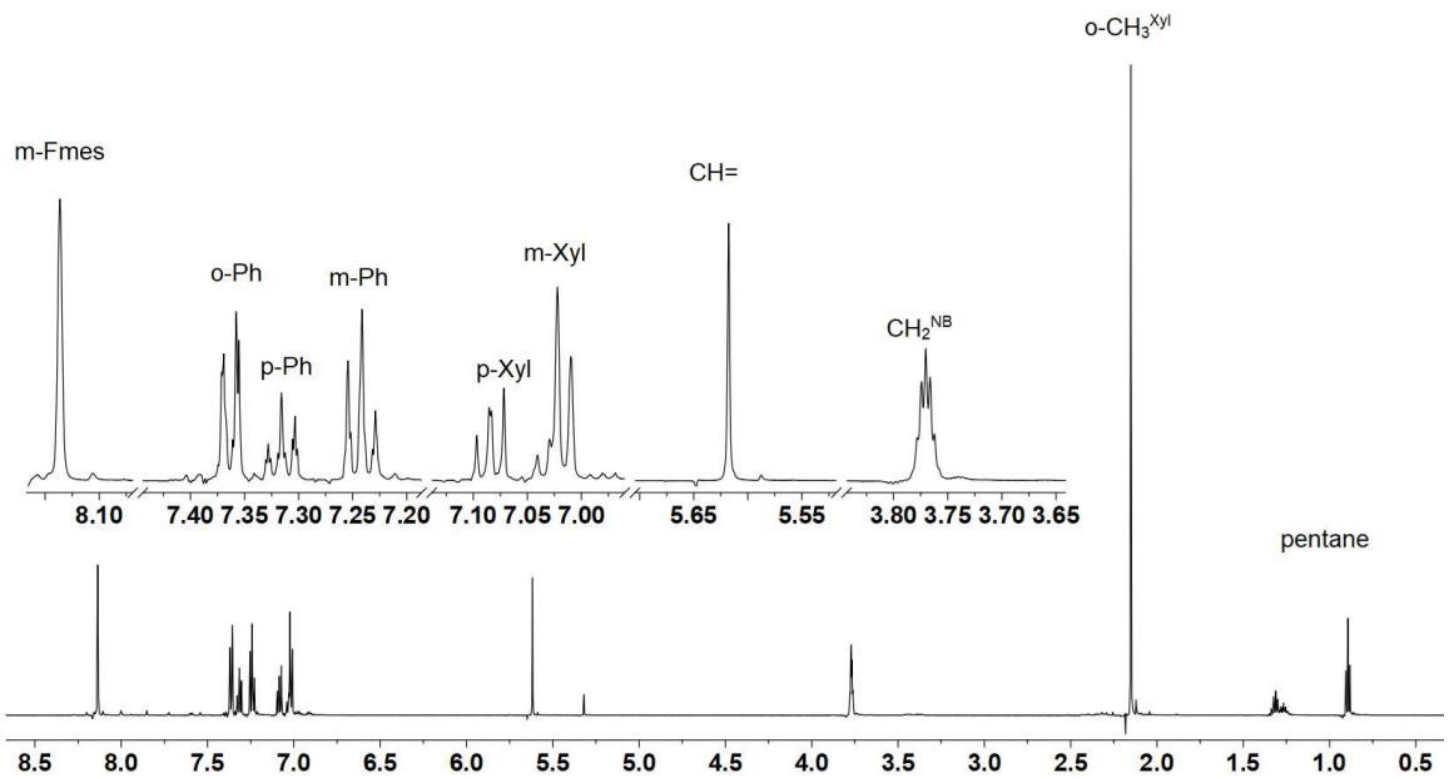

Figure S142. ${ }^{1} \mathrm{H}$ NMR (600 MHz, methylene chloride- $\left.d_{2}, 299 \mathrm{~K}\right)$ spectrum of compound $\mathbf{1 6 h}$.

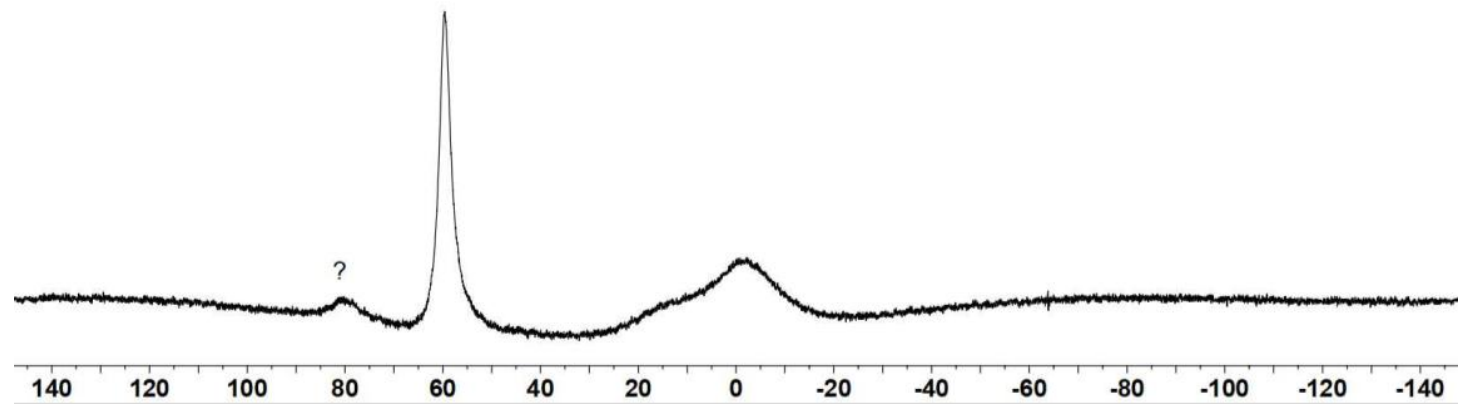

Figure S143. ${ }^{11} \mathrm{~B}\left\{{ }^{1} \mathrm{H}\right\} \mathrm{NMR}\left(192 \mathrm{MHz}\right.$, methylene chloride- $\left.d_{2}, 299 \mathrm{~K}\right)$ spectrum of compound $\mathbf{1 6 h}$.

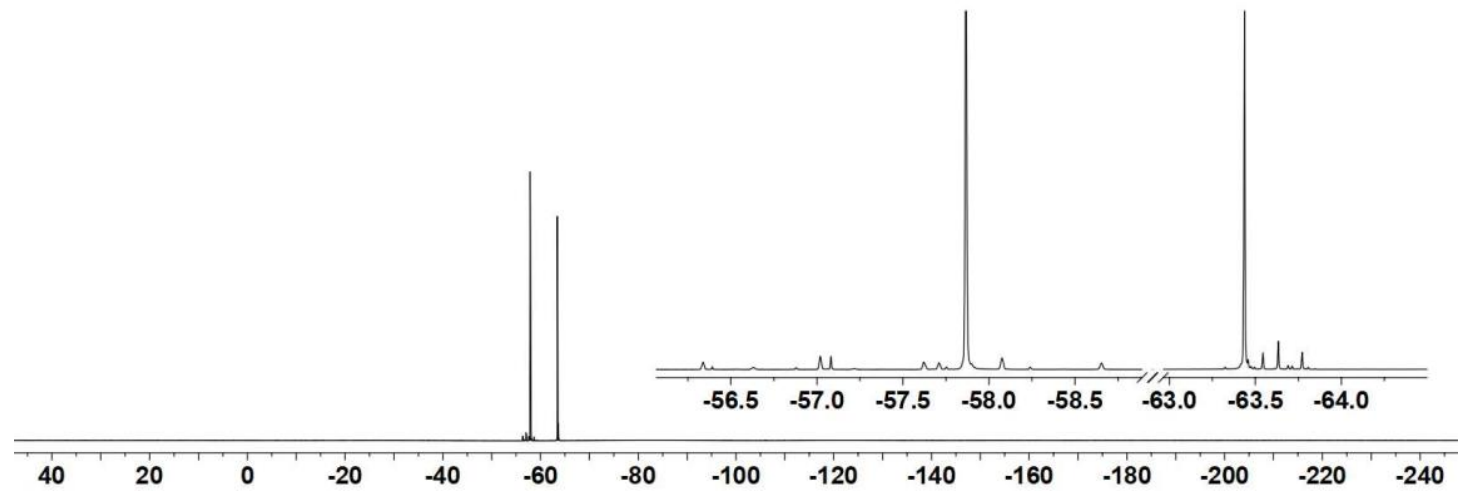

Figure S144. ${ }^{19} \mathrm{~F}$ NMR (564 MHz, methylene chloride- $d_{2}, 299 \mathrm{~K}$ ) spectrum of compound $\mathbf{1 6 h}$. 


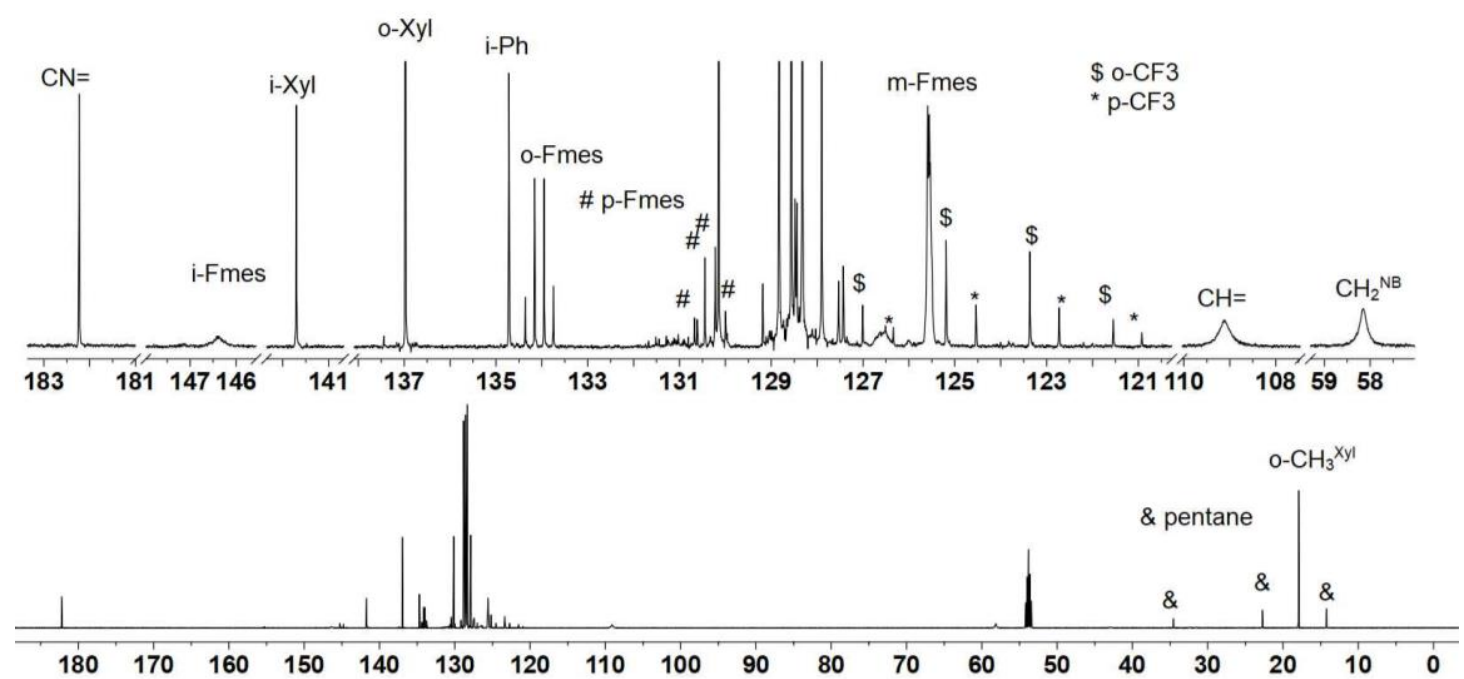

Figure S145. ${ }^{13} \mathrm{C}\left\{{ }^{1} \mathrm{H}\right\} \mathrm{NMR}\left(151 \mathrm{MHz}\right.$, methylene chloride- $\mathrm{d}_{2}, 299 \mathrm{~K}$ ) spectrum of compound $\mathbf{1 6 h}$.

The crystal suitable for X-ray diffraction analysis was obtained from the solution of compound $\mathbf{1 6 h}$ in pentane at $-35^{\circ} \mathrm{C}$.

X-ray crystal structure analysis of compound 16h (erk9760): A colorless prism-like specimen of $\mathrm{C}_{27.50} \mathrm{H}_{20.50} \mathrm{BF} 9 \mathrm{~N}$, approximate dimensions $0.100 \mathrm{~mm} \times 0.100 \mathrm{~mm} \times 0.160 \mathrm{~mm}$, was used for the $\mathrm{X}$ ray crystallographic analysis. The X-ray intensity data were measured. A total of 1458 frames were collected. The total exposure time was 19.05 hours. The frames were integrated with the Bruker SAINT software package using a wide-frame algorithm. The integration of the data using a triclinic unit cell yielded a total of 37024 reflections to a maximum $\theta$ angle of $66.67^{\circ}$ ( $0.84 \AA$ r resolution), of which 8689 were independent (average redundancy 4.261 , completeness $=99.2 \%, R_{\text {int }}=8.86 \%, R_{\text {sig }}$ $=7.00 \%)$ and $5636(64.86 \%)$ were greater than $2 \sigma\left(\mathrm{F}^{2}\right)$. The final cell constants of $\underline{a}=11.7841(3) \AA$, $\underline{\mathrm{b}}=14.7106(5) \AA, \underline{c}=15.8655(5) \AA, \alpha=110.309(2)^{\circ}, \beta=97.196(2)^{\circ}, \gamma=100.853(2)^{\circ}$, volume $=$ $2478.35(14) \AA^{3}$, are based upon the refinement of the XYZ-centroids of 3127 reflections above 20 $\sigma(\mathrm{l})$ with $6.615^{\circ}<2 \theta<133.1^{\circ}$. Data were corrected for absorption effects using the multi-scan method (SADABS). The ratio of minimum to maximum apparent transmission was 0.847 . The calculated minimum and maximum transmission coefficients (based on crystal size) are 0.8360 and 0.8930. The structure was solved and refined using the Bruker SHELXTL Software Package, using the space group $P-1$, with $Z=4$ for the formula unit, $\mathrm{C}_{27.50} \mathrm{H}_{20.50} \mathrm{BF}{ }_{9} \mathrm{~N}$. The final anisotropic fullmatrix least-squares refinement on $\mathrm{F}^{2}$ with 782 variables converged at $\mathrm{R} 1=5.48 \%$, for the observed data and $w R 2=15.44 \%$ for all data. The goodness-of-fit was 1.013 . The largest peak in the final difference electron density synthesis was $0.371 \mathrm{e}^{-} / \AA^{3}$ and the largest hole was $-0.282 \mathrm{e}^{-} / \AA^{3}$ with an RMS deviation of $0.059 \mathrm{e}^{-/} / \AA^{3}$. On the basis of the final model, the calculated density was 1.465 $\mathrm{g} / \mathrm{cm}^{3}$ and $\mathrm{F}(000), 1114 \mathrm{e} \cdot \mathrm{CCDC}$ number: 2041295. 


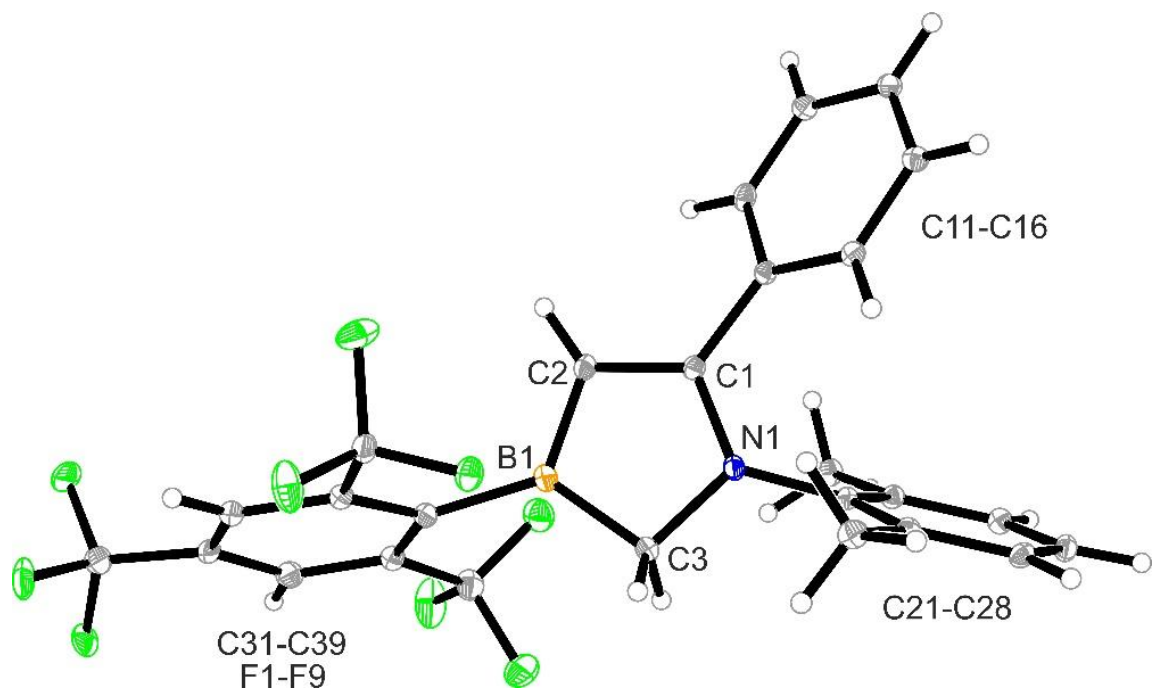

Figure S146. Crystal structure of compound 16h (thermal ellipsoids are set at 15\% probability).

\section{Preparation of the azaborinine derivative $28 \mathrm{~h}$}

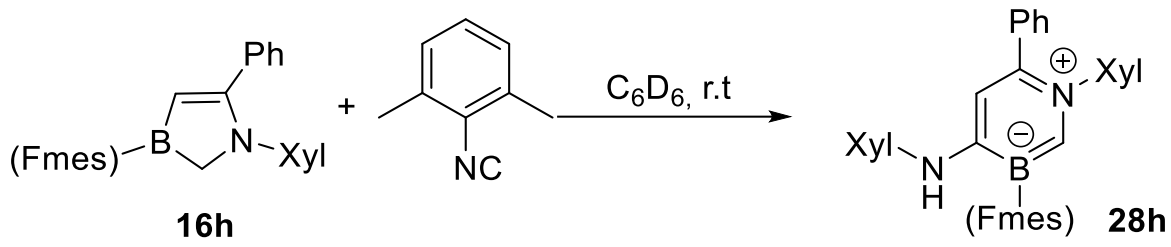

\section{Scheme S40.}

At room temperature, 2,6-dimethylphenyl isocyanide $(13.1 \mathrm{mg}, 0.1 \mathrm{mmol}, 1 \mathrm{eq}$.) was added to a solution of the azaborole $16 \mathrm{~h}\left(53 \mathrm{mg}, 0.10 \mathrm{mmol}, 1\right.$ eq.) in $\mathrm{C}_{6} \mathrm{D}_{6}(1 \mathrm{~mL})$ in a J. Young tube under an argon atmosphere. The resulting solution was stored at $r$. $t$. for overnight. Then all volatiles were removed in vacuo, the residue was dissolved in pentane $(1 \mathrm{~mL})$ and stored at $-35^{\circ} \mathrm{C}$ to finally give the product $28 \mathrm{~h}$ as a pale-yellow solid ( $32 \mathrm{mg}, 48 \%$ yield).

HRMS for $\mathrm{C}_{35} \mathrm{H}_{28} \mathrm{BN}_{2} \mathrm{~F}_{9}{ }^{+}[\mathrm{M}]^{+}$: calc. 658.2202; found: 658.2209 .

${ }^{1} \mathrm{H}$ NMR $\left(600 \mathrm{MHz}\right.$, methylene chloride- $\left.d_{2}, 299 \mathrm{~K}\right): \delta=8.20$ (s, $2 \mathrm{H}, m$-Fmes), $7.10(\mathrm{~m}, 5 \mathrm{H}, m$-Ph, $p$ $\left.\mathrm{Ph}, m-\left.\mathrm{Xy}\right|^{(4)},\right), 7.05\left(\mathrm{~m}, 4 \mathrm{H}, p-\mathrm{Xyl}^{(4)}, o-\mathrm{Ph}, p-\left.\mathrm{Xy}\right|^{(1)}\right), 6.95\left(\mathrm{~d},{ }^{3}{ }_{\mathrm{HH}}=7.6 \mathrm{~Hz}, 2 \mathrm{H}, m-\mathrm{Xy|}{ }^{(1)}\right), 6.63(\mathrm{~s}, 1 \mathrm{H}$, $\mathrm{C}(2) \mathrm{H}), 6.11(\mathrm{~s}, 1 \mathrm{H}, \mathrm{C}(5) \mathrm{H}), 5.48(\mathrm{~s}, 1 \mathrm{H}, \mathrm{NH}), 2.23\left(\mathrm{~s}, 6 \mathrm{H}, \mathrm{o}-\mathrm{CH}_{3} \mathrm{Xy}(4)\right), 2.05\left(\mathrm{~s}, 6 \mathrm{H}, \mathrm{o}-\mathrm{CH}_{3} \mathrm{Xyl}^{\mathrm{y}(1)}\right)$.

${ }^{13} \mathrm{C}\left\{{ }^{1} \mathrm{H}\right\}$ NMR (151 MHz, methylene chloride- $\left.d_{2}, 299 \mathrm{~K}\right): \delta=163.7$ (br, C(4)), 148.8 (br, i-Fmes), 145.7 $\left(i-\left.X y\right|^{(1)}\right), 140.7(C(6)), 139.3(\mathrm{br}, \mathrm{C}(2) \mathrm{H}), 137.8(i-\mathrm{Ph}), 137.6\left(i-\mathrm{Xy}{ }^{(4)}\right), 137.1$ (q, $\left.{ }^{2} \mathrm{~J}_{\mathrm{CF}}=29.8 \mathrm{~Hz}, o-\mathrm{Fmes}\right)$ $137.0\left(o-\mathrm{XY}^{(4)}\right), 134.5\left(o-\mathrm{XY}^{(1)}\right), 129.9$ (q, $^{2} \mathrm{~J}_{\mathrm{CF}}=33.8 \mathrm{~Hz}, p$-Fmes), $129.3(o-\mathrm{Ph}), 128.9\left(m-\mathrm{Xyl}^{(4)}\right), 128.4$ $\left(m-\right.$ Xyl $\left.^{(1)}\right), 128.2\left(p-\right.$ Xyl| $\left.^{(1)}\right), 127.9$ (p-Ph), $127.8(m-\mathrm{Ph}), 126.8$ (p-Xyl(4)), 125.6 (brm, $m$-Fmes ), 124.3 $\left(q,{ }^{1} J_{\mathrm{CF}}=275.0 \mathrm{~Hz}, o-\mathrm{CF}_{3}{ }^{\mathrm{Fmes}}\right), 123.8\left(q,{ }^{1} \mathrm{JFF}_{\mathrm{CF}}=272.8 \mathrm{~Hz}, p-\mathrm{CF}_{3}{ }^{\mathrm{Fmes}}\right), 110.0(\mathrm{C}(4) \mathrm{H}), 18.4\left(o-\mathrm{CH}_{3}{ }^{\mathrm{Xy}(4)}\right)$, $17.7\left(p-\mathrm{CH}_{3}{ }^{\mathrm{X}}(1)\right)$.

${ }^{11} \mathrm{~B}\left\{{ }^{1} \mathrm{H}\right\}$ NMR $\left(192 \mathrm{MHz}\right.$, methylene chloride- $\left.d_{2}, 299 \mathrm{~K}\right): \delta=26.4\left(\mathrm{v}_{1 / 2} \approx 330 \mathrm{~Hz}\right)$.

${ }^{19} \mathrm{~F}$ NMR $\left(564 \mathrm{MHz}\right.$, methylene chloride- $\left.d_{2}, 299 \mathrm{~K}\right): \delta=-59.0\left(\mathrm{~s}, 2 \mathrm{~F}, \mathrm{o}-\mathrm{CF}_{3}\right),-63.3\left(\mathrm{~s}, 1 \mathrm{~F}, p-\mathrm{CF}_{3}\right)$. 


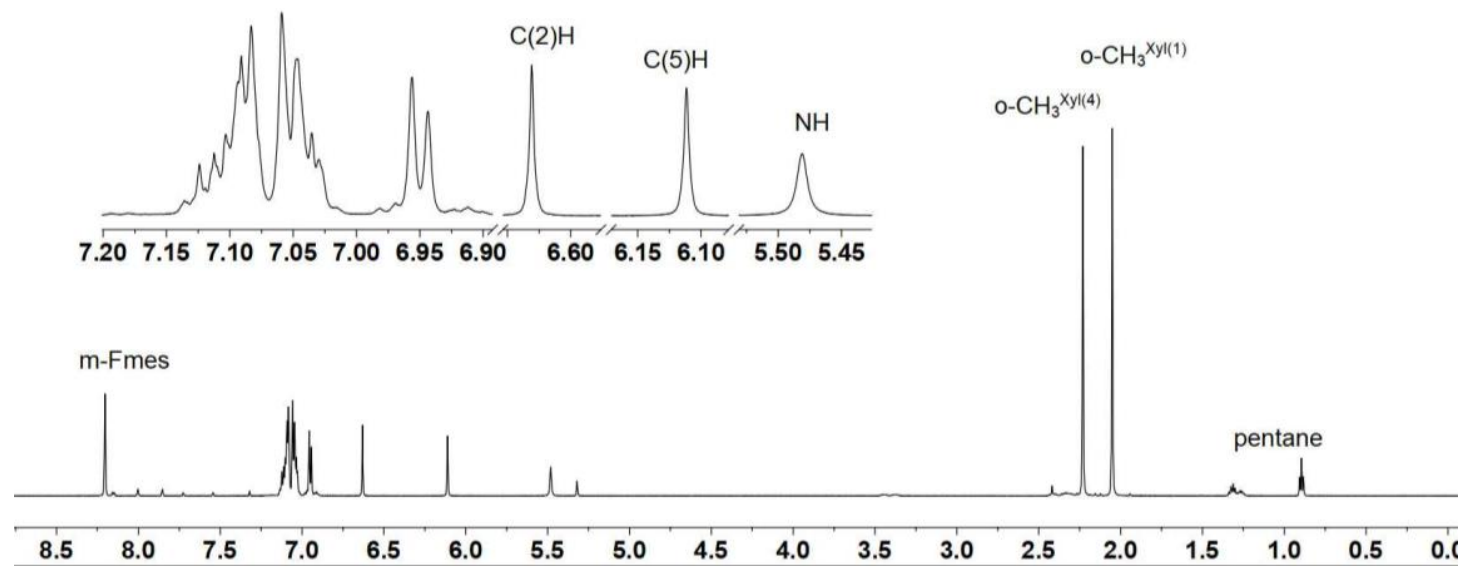

Figure S147. ${ }^{1} \mathrm{H}$ NMR (600 MHz, methylene chloride- $d_{2}, 299 \mathrm{~K}$ ) spectrum of compound $\mathbf{2 8 h}$.

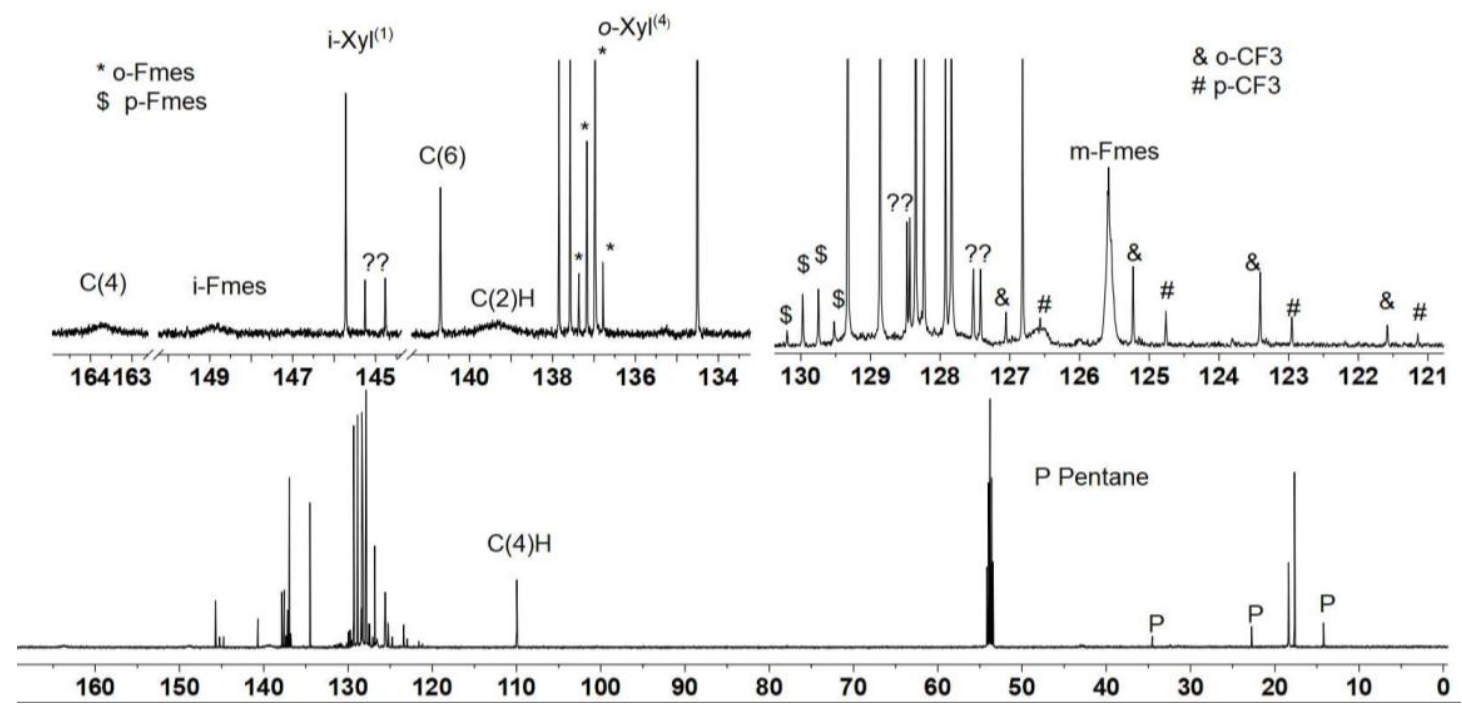

Figure S148. ${ }^{13} \mathrm{C}\left\{{ }^{1} \mathrm{H}\right\}$ NMR (151 MHz, methylene chloride- $\left.d_{2}, 299 \mathrm{~K}\right)$ spectrum of compound $\mathbf{2 8 h}$.

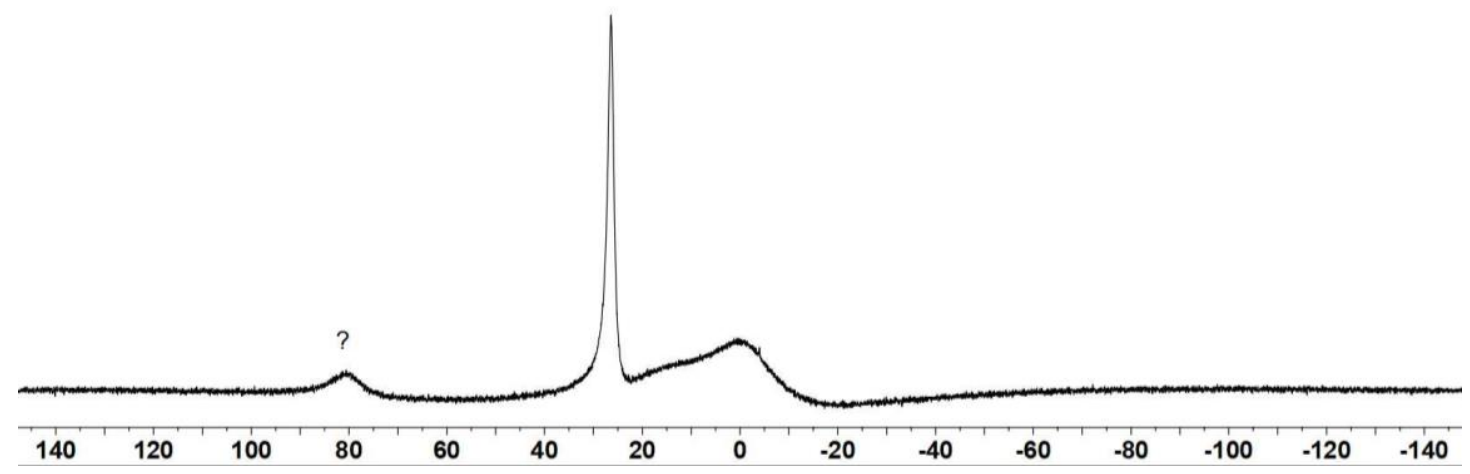

Figure S149. ${ }^{11} \mathrm{~B}\left\{{ }^{1} \mathrm{H}\right\}$ NMR (192 MHz, methylene chloride- $d_{2}, 299 \mathrm{~K}$ ) spectrum of compound $28 \mathrm{~h}$. 


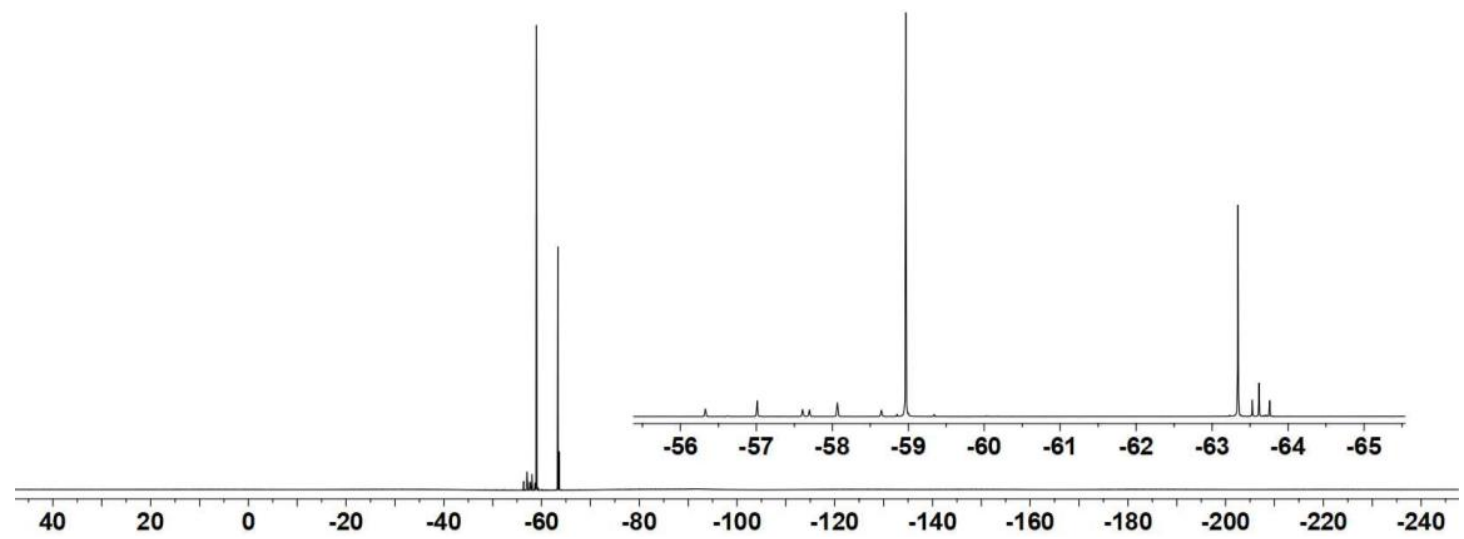

Figure S150. ${ }^{19} \mathrm{~F}$ NMR (564 MHz, methylene chloride- $d_{2}, 299 \mathrm{~K}$ ) spectrum of compound $\mathbf{2 8 h}$.

The crystal suitable for X-ray diffraction analysis was obtained from the solution of compound $\mathbf{2 8 h}$ in heptane and methylene chloride at room temperature.

X-ray crystal structure analysis of compound 28h (erk9892): A pale yellow plate-like specimen of $\mathrm{C}_{35} \mathrm{H}_{28} \mathrm{BF}_{9} \mathrm{~N}_{2}$, approximate dimensions $0.039 \mathrm{~mm} \times 0.119 \mathrm{~mm} \times 0.230 \mathrm{~mm}$, was used for the X-ray crystallographic analysis. The X-ray intensity data were measured on a Bruker D8 Venture PHOTON III Diffractometer system equipped with a micro focus tube $\mathrm{Cu} I m s$ (CuK $\alpha, \lambda=1.54178 \AA$ ) and a MX mirror monochromator. A total of 1654 frames were collected. The total exposure time was 22.59 hours. The frames were integrated with the Bruker SAINT software package using a wide-frame algorithm. The integration of the data using a triclinic unit cell yielded a total of 35269 reflections to a maximum $\theta$ angle of $66.78^{\circ}$ (0.84 $\AA$ resolution), of which 6347 were independent (average redundancy 5.557 , completeness $\left.=99.1 \%, R_{\text {int }}=7.09 \%, R_{\text {sig }}=4.45 \%\right)$ and $4836(76.19 \%)$ were greater than $2 \sigma\left(F^{2}\right)$. The final cell constants of $\underline{a}=8.69690(10) \AA, \underline{b}=11.9109(2) \AA, \underline{c}=17.6858(3)$ $\AA, \alpha=92.7280(10)^{\circ}, \beta=95.6760(10)^{\circ}, \gamma=97.7420(10)^{\circ}$, volume $=1802.98(5) \AA^{3}$, are based upon the refinement of the XYZ-centroids of 9958 reflections above $20 \sigma(I)$ with $5.030^{\circ}<2 \theta<133.1^{\circ}$. Data were corrected for absorption effects using the Multi-Scan method (SADABS). The ratio of minimum to maximum apparent transmission was 0.878 . The calculated minimum and maximum transmission coefficients (based on crystal size) are 0.8210 and 0.9660 . The structure was solved and refined using the Bruker SHELXTL Software Package, using the space group $P-1$, with $Z=2$ for the formula unit, $\mathrm{C}_{35} \mathrm{H}_{28} \mathrm{BF}_{9} \mathrm{~N}_{2}$. The final anisotropic full-matrix least-squares refinement on $\mathrm{F}^{2}$ with 489 variables converged at $\mathrm{R} 1=5.04 \%$, for the observed data and $\mathrm{wR} 2=12.67 \%$ for all data. The goodness-of-fit was 1.029. The largest peak in the final difference electron density synthesis was $0.269 \mathrm{e}^{-} / \AA^{3}$ and the largest hole was $-0.244 \mathrm{e}^{-} / \AA^{3}$ with an RMS deviation of $0.046 \mathrm{e}^{-} / \AA^{3}$. On the basis of the final model, the calculated density was $1.213 \mathrm{~g} / \mathrm{cm}^{3}$ and $F(000), 676 \mathrm{e}^{-}$. The hydrogen at N1 atom was refined freely. CCDC number: 2041302. 


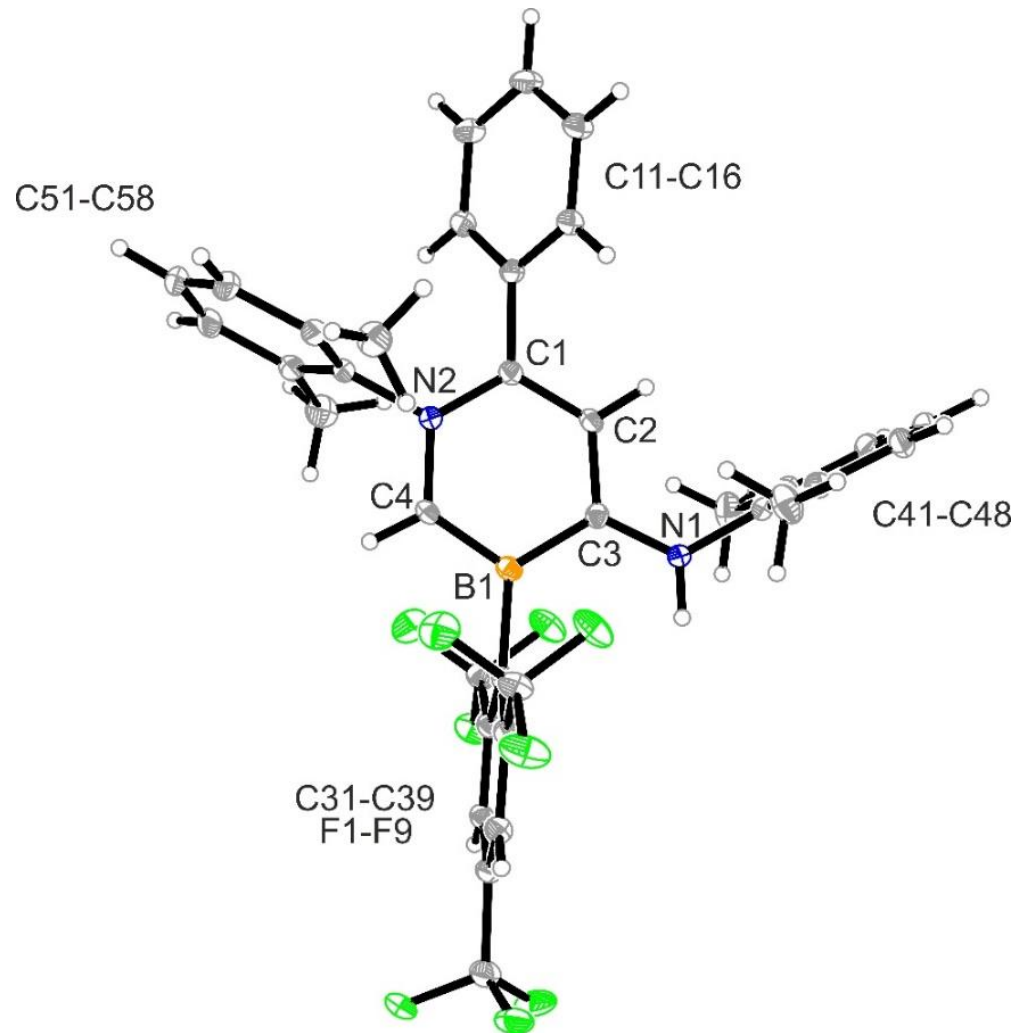

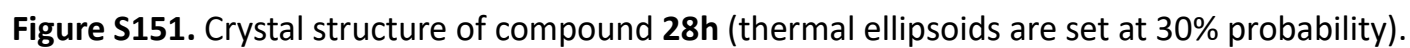

\section{Preparation of the azaborinine derivative $\mathbf{2 8} \mathbf{i}$}

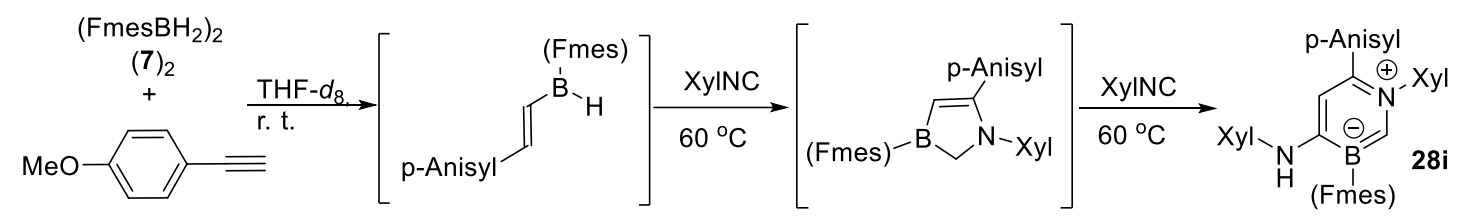

Scheme S41.

At room temperature, 1-ethynyl-4-methoxybenzene ( $26.4 \mathrm{mg}, 0.2 \mathrm{mmol}, 1$ equiv.) was added to the solution of borane $(7)_{2}\left(58.8 \mathrm{mg}, 0.2 \mathrm{mmol}, 1\right.$ equiv.) in THF- $d_{8}(1 \mathrm{~mL})$ in a J. Young tube under the argon atmosphere. The mixture was stored at room temperature for $1 \mathrm{~h}$, then 2,6dimethylphenyl isocyanide $(26.2 \mathrm{mg}, 0.2 \mathrm{mmol}, 1$ equiv.) was added and the resulting solution was stored at $60^{\circ} \mathrm{C}$ for 2 days. One more equivalent 2,6-dimethylphenyl isocyanide ( $26.2 \mathrm{mg}, 0.2 \mathrm{mmol}$ ) was added and the mixture was stored at $60^{\circ} \mathrm{C}$ for 1 day more. All volatiles were removed in vacuo and the residue was purified by flash chromatography with pentane: methylene chloride (10:1) as eluent to finally give compound $\mathbf{2 8 i}$ as yellow solid ( $38 \mathrm{mg}, 28 \%$ yield).

HRMS for $\mathrm{C}_{36} \mathrm{H}_{33} \mathrm{~N}_{2} \mathrm{BO}_{2} \mathrm{~F}_{9}{ }^{+}\left[\mathrm{M}+\mathrm{H}_{3} \mathrm{O}\right]^{+}$: calc. 723.2441; found: 723.2438 .

${ }^{1} \mathrm{H}$ NMR $\left(600 \mathrm{MHz}\right.$, methylene chloride- $\left.d_{2}, 299 \mathrm{~K}\right): \delta=8.19\left(\mathrm{~s}, 2 \mathrm{H}, m\right.$-Fmes), $7.06\left(\mathrm{~m}, 4 \mathrm{H}, m-\mathrm{Xy}{ }^{(4)}\right.$, $p$-Xyl $\left.{ }^{(4)}, p-X^{(1)}\right), 6.96\left(m, 4 \mathrm{H}, o\right.$-Anisyl, $m$-Xy| $\left.{ }^{(1)}\right), 6.61(\mathrm{~m}, 2 \mathrm{H}, m$-Anisyl), $6.59(\mathrm{~s}, 1 \mathrm{H}, \mathrm{C}(2) \mathrm{H}), 6.07(\mathrm{~s}$, $1 \mathrm{H}, \mathrm{C}(5) \mathrm{H}), 5.45(\mathrm{~s}, 1 \mathrm{H}, \mathrm{NH}), 3.67\left(\mathrm{~s}, 3 \mathrm{H}, \mathrm{OCH}_{3}\right), 2.22\left(\mathrm{~s}, 6 \mathrm{H}, o-\mathrm{CH}_{3}{ }^{\mathrm{Xy}((4))}\right), 2.03\left(\mathrm{~s}, 6 \mathrm{H}, o-\mathrm{CH}_{3}{ }^{\mathrm{Xy}(1)}\right)$.

${ }^{13} \mathrm{C}\left\{{ }^{1} \mathrm{H}\right\}$ NMR (151 MHz, methylene chloride- $\left.d_{2}, 299 \mathrm{~K}\right)$ [selected resonances]: $\delta=163.8(\mathrm{br}, \mathrm{C}(4))$, 159.4 (p-Anisyl), 149.0 (br, i-Fmes), $145.8\left(i-\right.$ Xyl$\left.^{(1)}\right), 140.5(C(6)), 139.0(\mathrm{br}, \mathrm{C}(2) \mathrm{H}) 137.6\left(i-\mathrm{Xyl}^{(4)}\right)$, $137.0\left(o-\mathrm{XYl}^{(4)}\right), 134.4\left(o-\mathrm{XYl}^{(4)}\right), 130.5$ (o-Anisyl), 130.2 (i-Anisyl), $128.8\left(m-\mathrm{XYl}^{(4)}\right), 128.4\left(m-\mathrm{Xy}^{(1)}\right)$, 
$128.2\left(p-\mathrm{Xyl}^{(1)}\right), 126.8\left(p-\mathrm{Xyl}^{(4)}\right), 125.5$ (br, i-Fmes), 113.2 (m-Anisyl), $109.9(\mathrm{C}(5) \mathrm{H}), 55.4\left(\mathrm{OCH}_{3}\right), 18.4$ $\left(o-\mathrm{CH}_{3}{ }^{\mathrm{Xy}(4)}\right), 17.6\left(0-\mathrm{CH}_{3}{ }^{\mathrm{Xyl}(1)}\right)$.

${ }^{11} \mathrm{~B}\left\{{ }^{1} \mathrm{H}\right\}$ NMR (192 MHz, methylene chloride- $\left.d_{2}, 299 \mathrm{~K}\right): \delta=26.1\left(\mathrm{v}_{1 / 2} \approx 330 \mathrm{~Hz}\right)$.

${ }^{19} \mathrm{~F}$ NMR (564 MHz, methylene chloride- $\left.d_{2}, 299 \mathrm{~K}\right): \delta=-59.0\left(\mathrm{~s}, 2 \mathrm{~F}, \mathrm{o}-\mathrm{CF}_{3}\right),-63.3\left(\mathrm{~s}, 1 \mathrm{~F}, p-\mathrm{CF}_{3}\right)$.
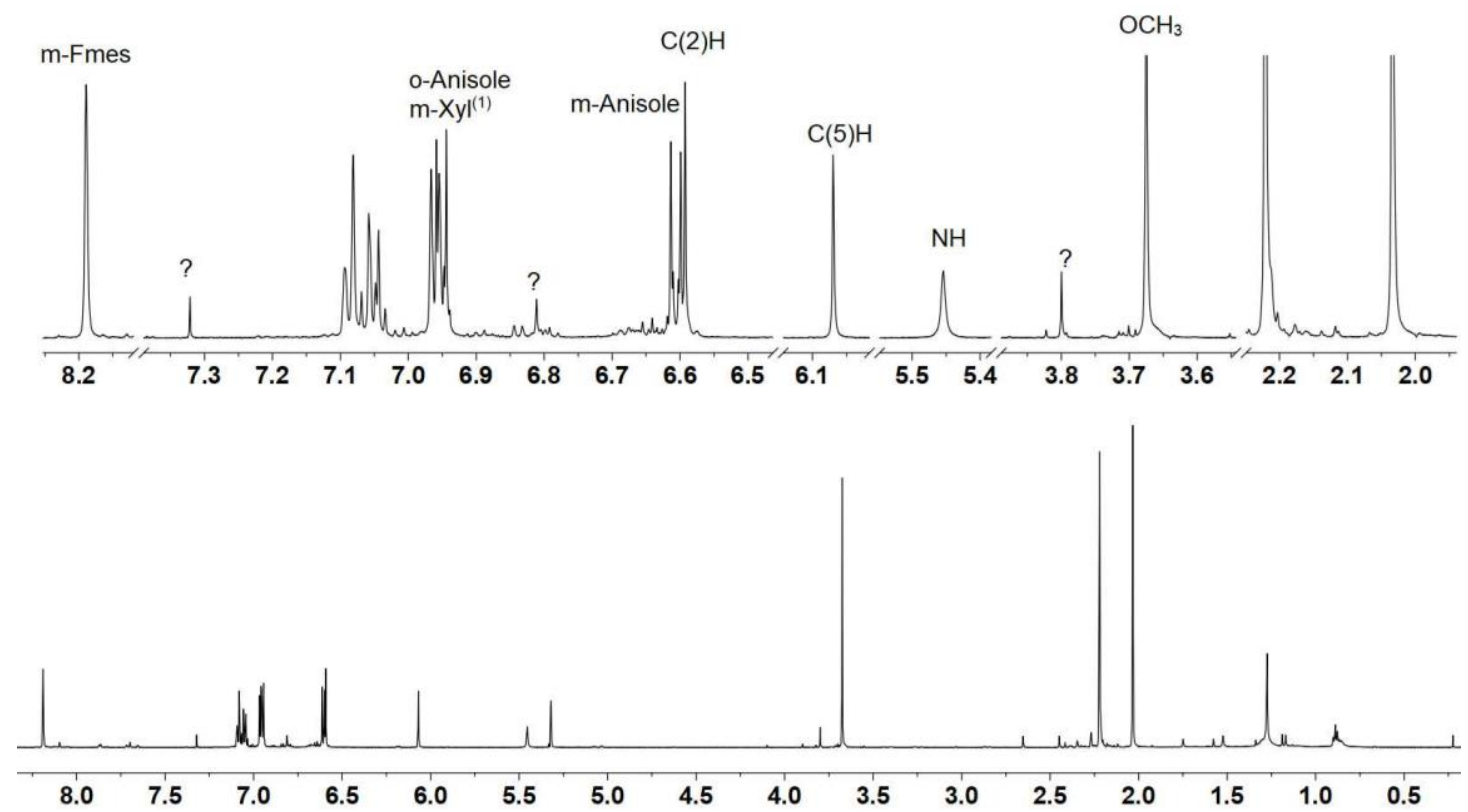

Figure S152. ${ }^{1} \mathrm{H}$ NMR (600 MHz, methylene chloride- $\left.d_{2}, 299 \mathrm{~K}\right)$ spectrum of compound $28 \mathrm{i}$.

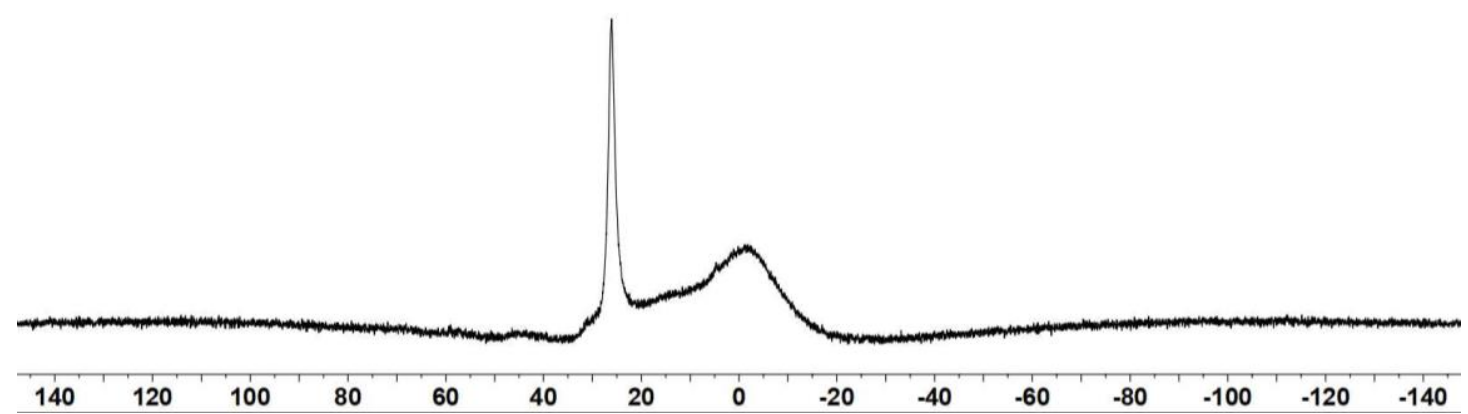

Figure S153. ${ }^{11} \mathrm{~B}\left\{{ }^{1} \mathrm{H}\right\}$ NMR (192 MHz, methylene chloride- $\left.d_{2}, 299 \mathrm{~K}\right)$ spectrum of compound $28 \mathbf{i}$.

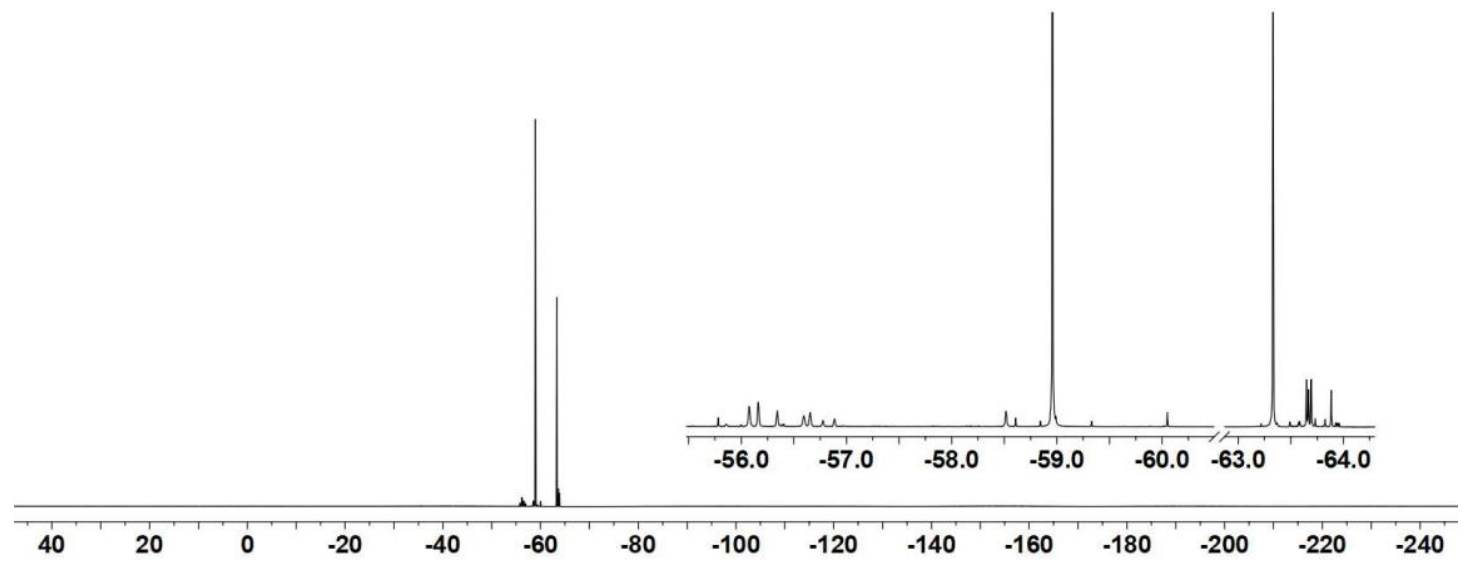

Figure S154. ${ }^{19} \mathrm{~F}$ NMR (564 MHz, methylene chloride- $d_{2}, 299 \mathrm{~K}$ ) spectrum of compound $28 \mathrm{i}$. 

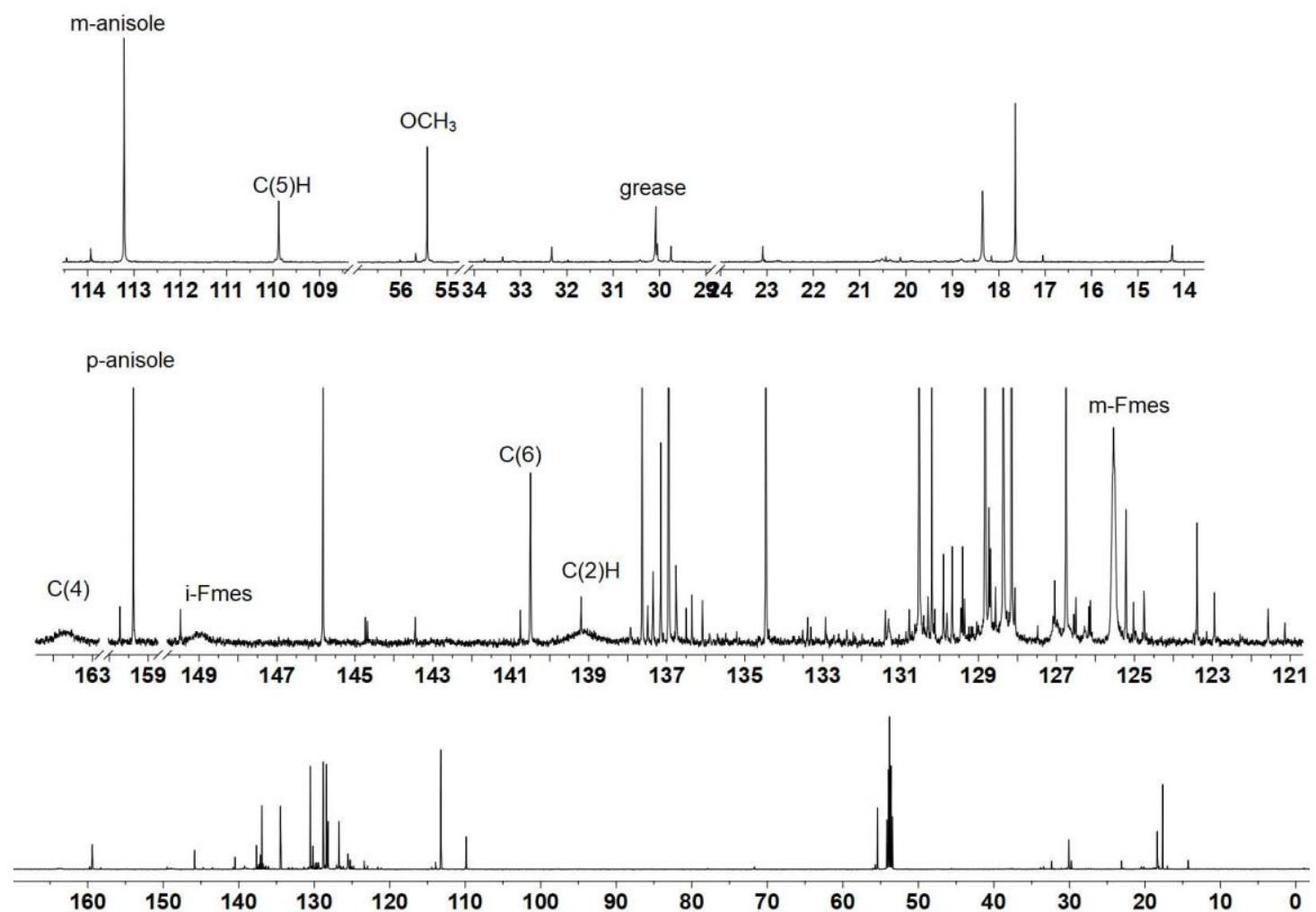

Figure $\mathbf{S 1 5 5 .}{ }^{13} \mathrm{C}\left\{{ }^{1} \mathrm{H}\right\} \mathrm{NMR}$ (151 MHz, methylene chloride- $d_{2}, 299 \mathrm{~K}$ ) spectrum of compound $\mathbf{2 8 i}$.

The crystal suitable for X-ray diffraction analysis was obtained from the solution of compound $\mathbf{2 8 \mathbf { i }}$ in pentane at $0^{\circ} \mathrm{C}$.

X-ray crystal structure analysis of compound 28i (erk9733): A yellow plate-like specimen of $\mathrm{C}_{36} \mathrm{H}_{30} \mathrm{BF}_{9} \mathrm{~N}_{2} \mathrm{O}$, approximate dimensions $0.080 \mathrm{~mm} \times 0.200 \mathrm{~mm} \times 0.200 \mathrm{~mm}$, was used for the X-ray crystallographic analysis. The X-ray intensity data were measured. A total of 1395 frames were collected. The total exposure time was 20.18 hours. The frames were integrated with the Bruker SAINT software package using a wide-frame algorithm. The integration of the data using an orthorhombic unit cell yielded a total of 56281 reflections to a maximum $\theta$ angle of $66.77^{\circ}$ ( $0.84 \AA$ resolution), of which 10789 were independent (average redundancy 5.217, completeness $=99.2 \%$, $\left.\mathrm{R}_{\text {int }}=5.07 \%, \mathrm{R}_{\text {sig }}=3.55 \%\right)$ and $9924(91.98 \%)$ were greater than $2 \sigma\left(\mathrm{F}^{2}\right)$. The final cell constants of a $=22.8203(6) \AA, \underline{b}=8.8132(3) \AA, \underline{c}=31.8125(9) \AA$, volume $=6398.1(3) \AA^{3}$, are based upon the refinement of the XYZ-centroids of 9695 reflections above $20 \sigma(I)$ with $8.232^{\circ}<2 \theta<133.2^{\circ}$. Data were corrected for absorption effects using the multi-scan method (SADABS). The ratio of minimum to maximum apparent transmission was 0.841 . The calculated minimum and maximum transmission coefficients (based on crystal size) are 0.8170 and 0.9200 . The structure was solved and refined using the Bruker SHELXTL Software Package, using the space group $P c a 2_{1}$, with $Z=8$ for the formula unit, $\mathrm{C}_{36} \mathrm{H}_{30} \mathrm{BF}_{9} \mathrm{~N}_{2} \mathrm{O}$. The final anisotropic full-matrix least-squares refinement on $\mathrm{F}^{2}$ with 957 variables converged at $\mathrm{R} 1=3.30 \%$, for the observed data and $\mathrm{wR} 2=8.10 \%$ for all data. The goodness-of-fit was 1.029. The largest peak in the final difference electron density synthesis was $0.422 \mathrm{e}^{-} / \AA^{3}$ and the largest hole was $-0.254 \mathrm{e}^{-} / \AA^{3}$ with an RMS deviation of $0.040 \mathrm{e}^{-} / \AA^{3}$. On the basis of the final model, the calculated density was $1.429 \mathrm{~g} / \mathrm{cm}^{3}$ and $F(000), 2832 \mathrm{e}^{-}$. The hydrogens at N1A and N1B atoms were refined freely. CCDC number: 2041303. 


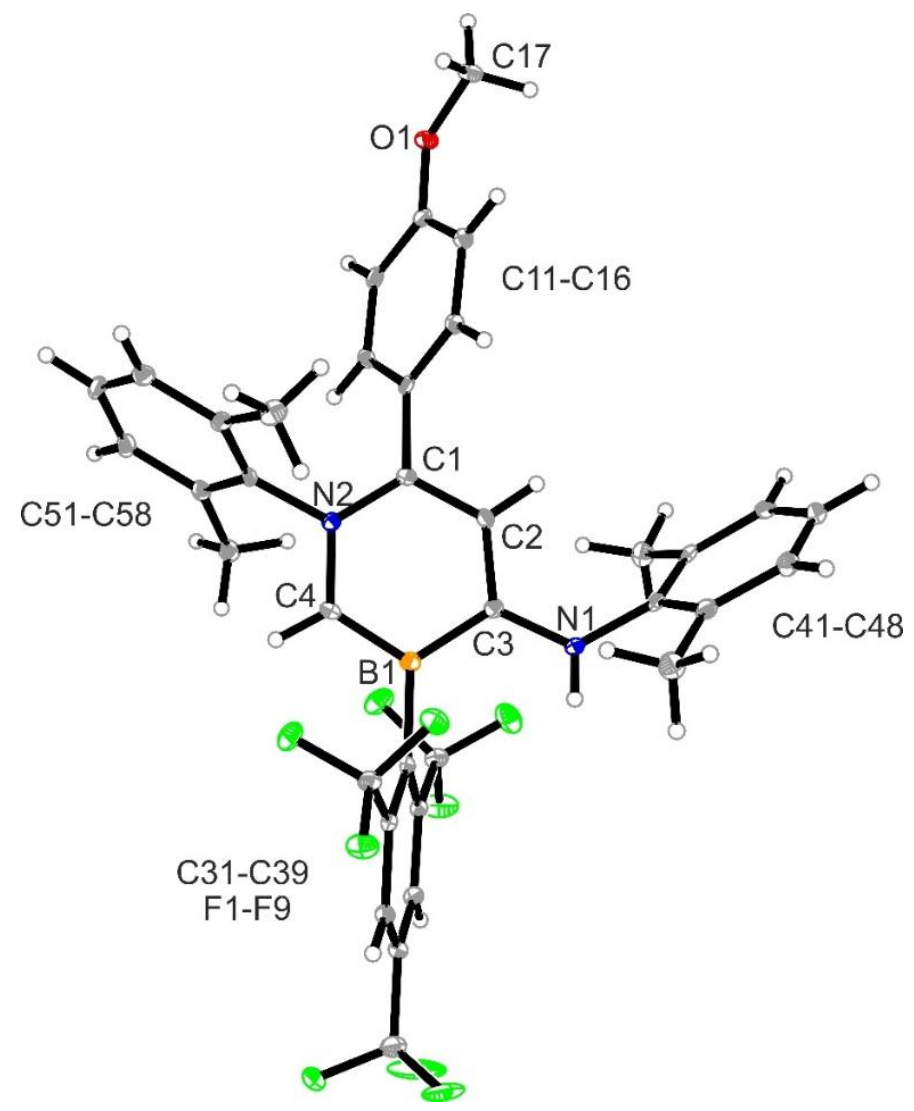

Figure S156. Crystal structure of compound 28i (thermal ellipsoids are set at 30\% probability).

\section{Preparation of the azaborinine derivative $28 \mathrm{k}$}

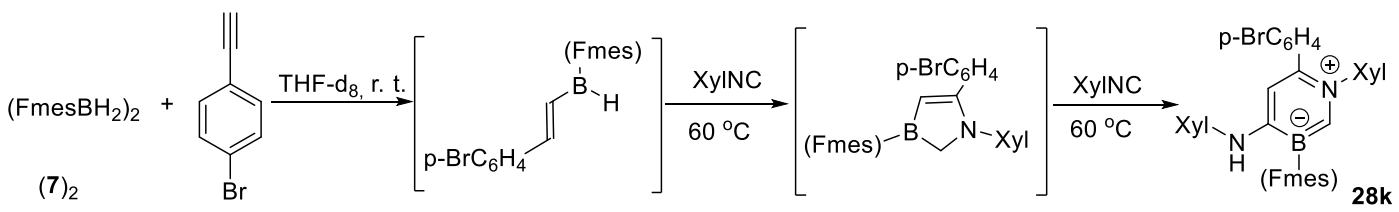

\section{Scheme S42.}

At room temperature, 1-bromo-4-ethynylbenzene ( $36.2 \mathrm{mg}, 0.2 \mathrm{mmol}, 1$ equiv.) was added to the solution of borane $(7)_{2}\left(58.8 \mathrm{mg}, 0.2 \mathrm{mmol}, 1\right.$ equiv.) in THF- $d_{8}(1 \mathrm{~mL})$ in a J. Young tube under an argon atmosphere. The mixture was stored at room temperature overnight. Then 2,6dimethylphenyl isocyanide $(26.2 \mathrm{mg}, 0.2 \mathrm{mmol}, 1$ equiv.) was added and the resulting mixture was stored at $60^{\circ} \mathrm{C}$ for 2 days. One more equivalent 2,6-dimethylphenyl isocyanide ( $26.2 \mathrm{mg}, 0.2 \mathrm{mmol}$ ) was added and the solution was stored at $60^{\circ} \mathrm{C}$ for 1 day more. Then all volatiles were removed in vacuo and the residue was purified by flash chromatography with pentane: methylene chloride (20:1) as eluent to finally give the compound $\mathbf{2 8 k}$ as yellow solid (59 $\mathrm{mg}, 40 \%$ yield). HRMS for $\mathrm{C}_{35} \mathrm{H}_{27} \mathrm{~N}_{2} \mathrm{BBrF}_{9}{ }^{+}[\mathrm{M}]^{+}$: calc. 736.1308; found: 736.1319.

${ }^{1} \mathrm{H}$ NMR $\left(600 \mathrm{MHz}\right.$, methylene chloride- $\left.d_{2}, 299 \mathrm{~K}\right): \delta=8.20$ (s, 2H, $m$-Fmes), $7.22(\mathrm{~m}, 2 \mathrm{H}, m-p-\mathrm{Br}-$ $\left.\mathrm{C}_{6} \mathrm{H}_{4}\right), 7.08\left(\mathrm{~m}, 4 \mathrm{H}, m-\mathrm{Xyl}^{(4)}, p-\mathrm{Xyl}^{(4)}, p-\left.\mathrm{Xy}\right|^{(1)}\right), 6.97\left(\mathrm{~m}, 2 \mathrm{H}, m-\mathrm{Xyl}^{(1)}\right), 6.91\left(\mathrm{~m}, 2 \mathrm{H}, o-p-\mathrm{Br}^{-} \mathrm{C}_{6} \mathrm{H}_{4}\right), 6.64$ $(\mathrm{s}, 1 \mathrm{H}, \mathrm{C}(2) \mathrm{H}), 6.08(\mathrm{~s}, 1 \mathrm{H}, \mathrm{C}(5) \mathrm{H}), 5.50(\mathrm{~s}, 1 \mathrm{H}, \mathrm{NH}), 2.22\left(\mathrm{~s}, 6 \mathrm{H}, o-\mathrm{CH}_{3}{ }^{\mathrm{Xy}(4)}\right), 2.03\left(\mathrm{~s}, 6 \mathrm{H}, o-\mathrm{CH}_{3}{ }^{\mathrm{Xy}(1)}\right)$. ${ }^{13} \mathrm{C}\left\{{ }^{1} \mathrm{H}\right\}$ NMR $\left(151 \mathrm{MHz}\right.$, methylene chloride- $\left.d_{2}, 299 \mathrm{~K}\right): \delta=163.8(\mathrm{br}, \mathrm{C}(4)), 148.6(\mathrm{br}, i-\mathrm{Fmes}), 145.4$ $\left(i-\left.X\right|^{(1)}\right), 139.6(C(2) H), 139.4(C(6)), 137.4\left(i-\left.X y\right|^{(4)}\right), 137.0\left(q^{2}{ }^{2} J_{F C}=29.4 \mathrm{~Hz}, o-F m e s\right) 136.9\left(o-\left.X y\right|^{(4)}\right)$, 
$136.8\left(i-p-\mathrm{Br}_{-} \mathrm{C}_{6} \mathrm{H}_{4}\right), 134.4\left(o-\mathrm{Xyl}^{(1)}\right), 131.04\left(o-p-\mathrm{Br}-\mathrm{C}_{6} \mathrm{H}_{4}\right), 130.98\left(m-p-\mathrm{Br}_{-} \mathrm{C}_{6} \mathrm{H}_{4}\right), 129.9\left(q,{ }^{2} \mathrm{JFC}_{\mathrm{FC}}=33.8\right.$

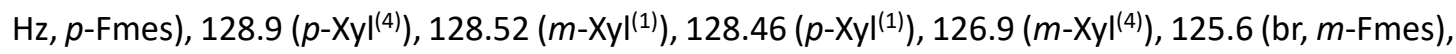
$124.3\left(q,{ }^{1} \mathrm{JC}_{\mathrm{FC}}=275.0 \mathrm{~Hz}, o-\mathrm{CF}_{3}{ }^{\mathrm{Fmes}}\right), 123.8\left(\mathrm{q},{ }^{1} J_{\mathrm{FC}}=272.1 \mathrm{~Hz}, p-\mathrm{CF}_{3}{ }^{\mathrm{Fmes}}\right), 122.2\left(p-p-\mathrm{Br}_{-} \mathrm{C}_{6} \mathrm{H}_{4}\right), 109.8$ $(\mathrm{C}(5) \mathrm{H}), 18.3\left(\mathrm{q}, \mathrm{J}_{\mathrm{FC}}=1.3 \mathrm{~Hz}, o-\mathrm{CH}_{3}{ }^{\mathrm{Xy}}(4)\right), 17.6\left(o-\mathrm{CH}_{3}{ }^{\mathrm{Xy}}(1)\right)$.

${ }^{11} \mathrm{~B}\left\{{ }^{1} \mathrm{H}\right\}$ NMR $\left(192 \mathrm{MHz}\right.$, methylene chloride- $\left.d_{2}, 299 \mathrm{~K}\right): \delta=26.5\left(\mathrm{v}_{1 / 2} \approx 350 \mathrm{~Hz}\right)$.

${ }^{19} \mathrm{~F}$ NMR $\left(564 \mathrm{MHz}\right.$, methylene chloride- $\left.d_{2}, 299 \mathrm{~K}\right): \delta=-59.0\left(\mathrm{~s}, 2 \mathrm{~F}, o-\mathrm{CF}_{3}\right),-63.4\left(\mathrm{~s}, 1 \mathrm{~F}, p-\mathrm{CF}_{3}\right)$.

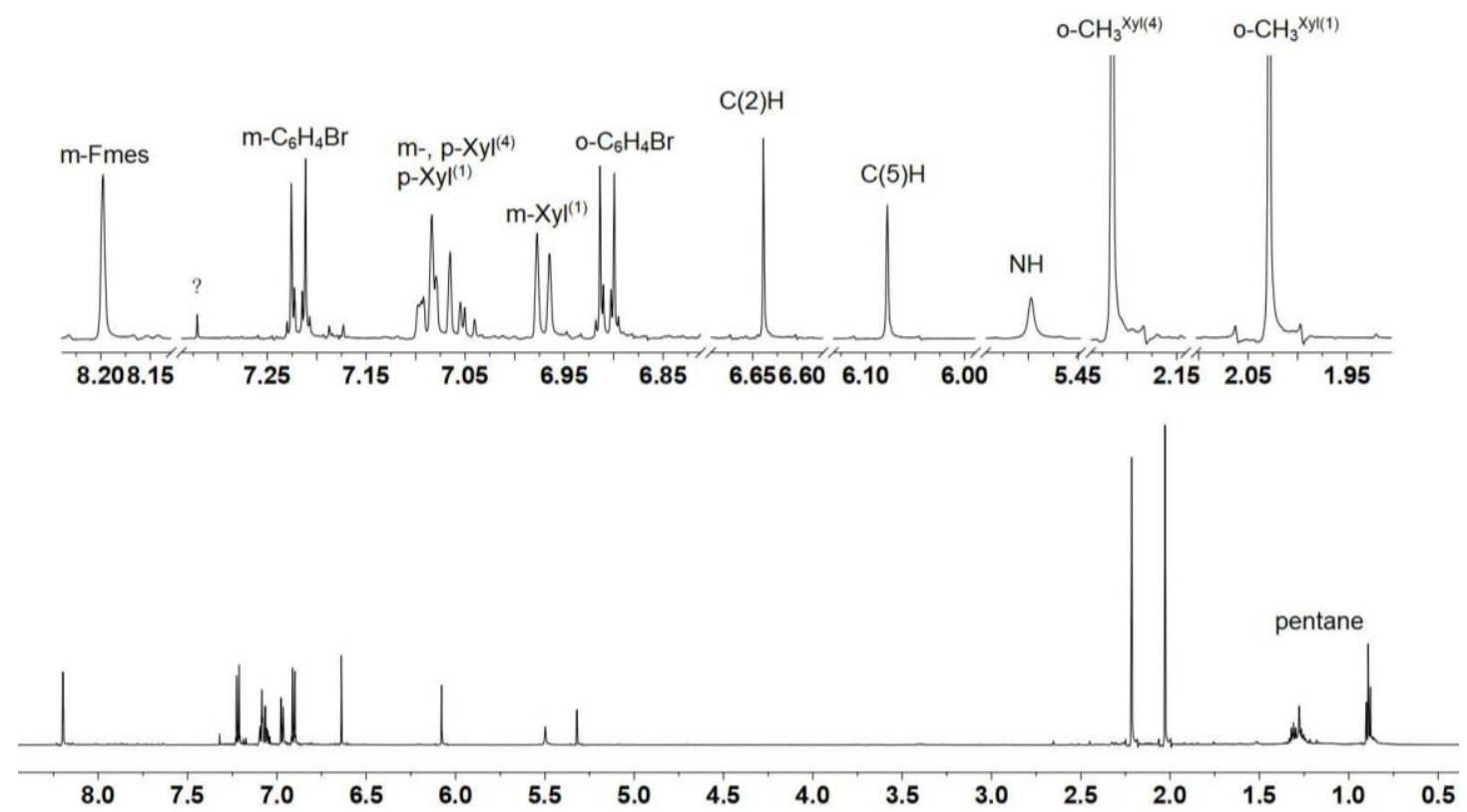

Figure S157. ${ }^{1} \mathrm{H}$ NMR (600 MHz, methylene chloride- $d_{2}, 299 \mathrm{~K}$ ) spectrum of compound 28k.

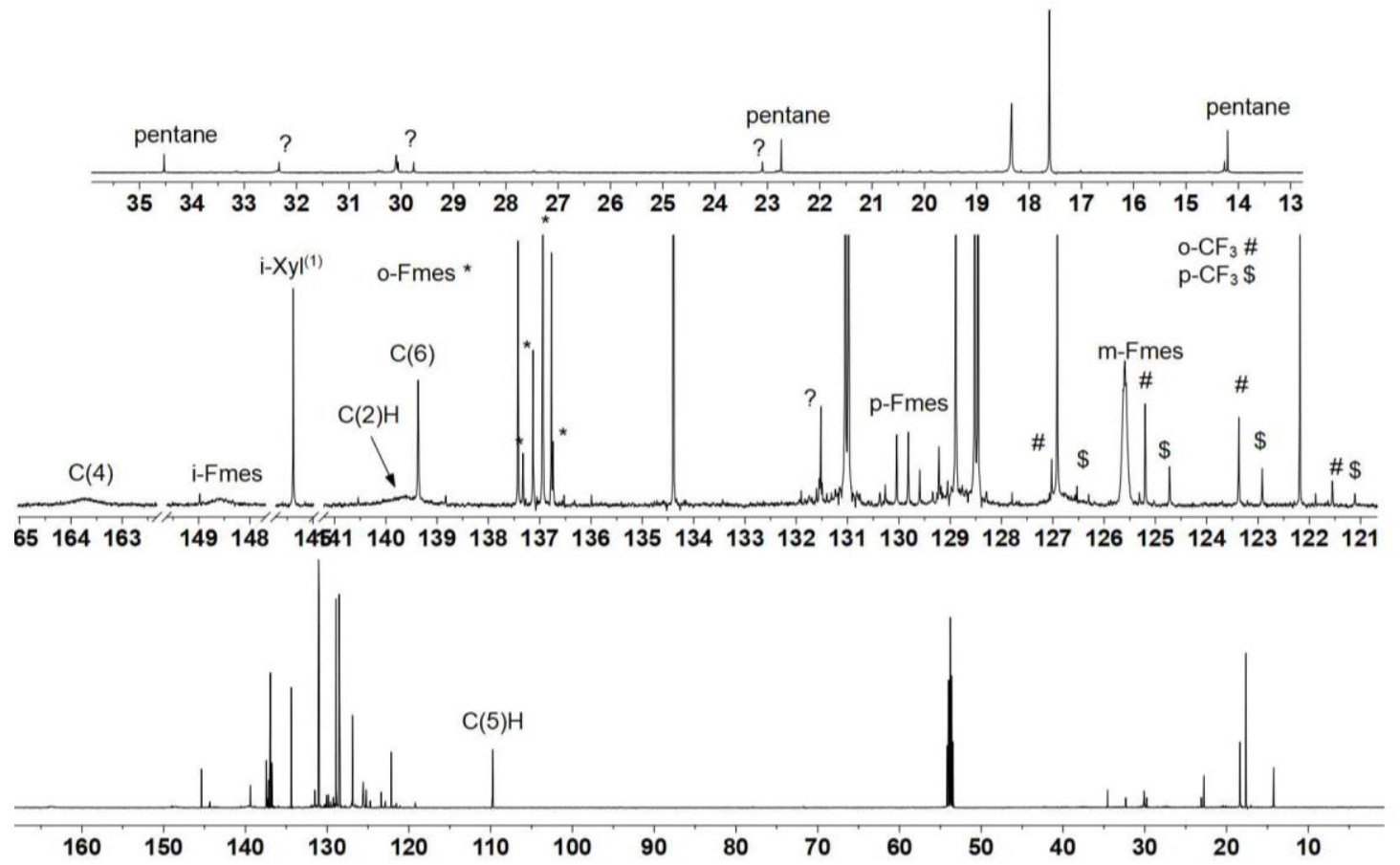

Figure S158. ${ }^{13} \mathrm{C}\left\{{ }^{1} \mathrm{H}\right\}$ NMR (151 MHz, methylene chloride- $\left.d_{2}, 299 \mathrm{~K}\right)$ spectrum of compound $\mathbf{2 8 k}$. 


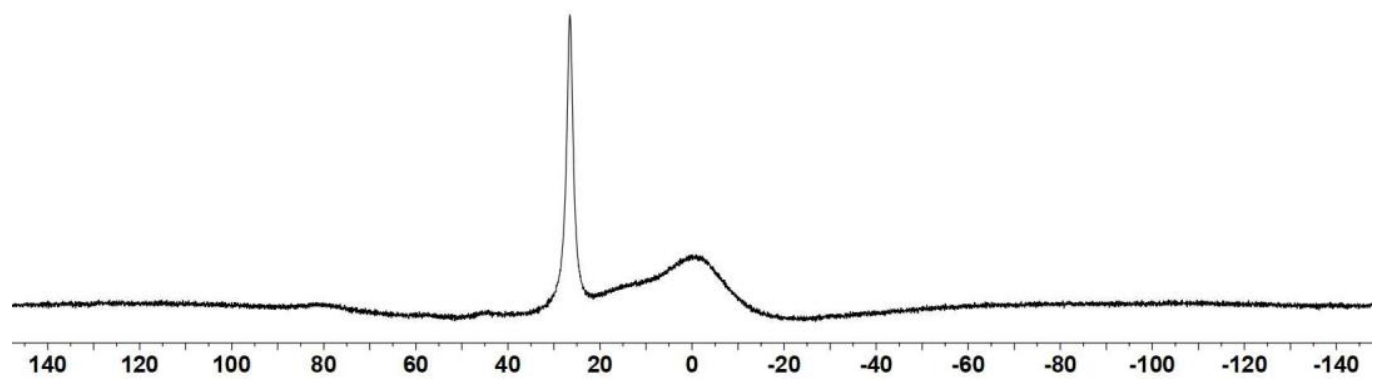

Figure S159. ${ }^{11} \mathrm{~B}\left\{{ }^{1} \mathrm{H}\right\}$ NMR (192 MHz, methylene chloride- $\left.d_{2}, 299 \mathrm{~K}\right)$ spectrum of compound 26k.

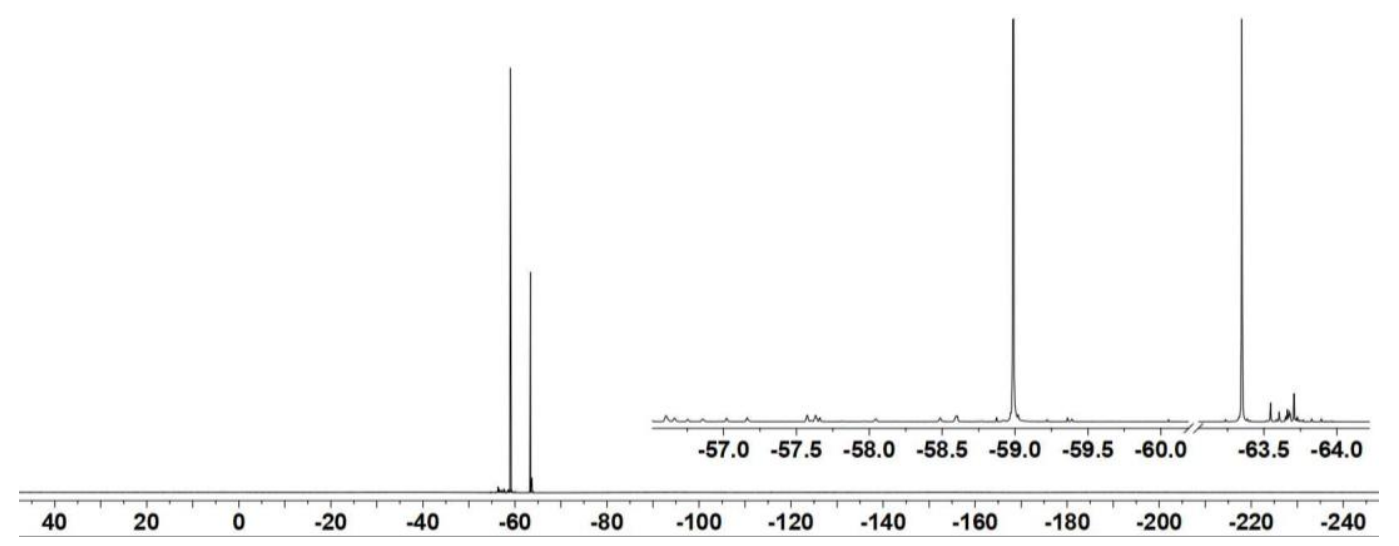

Figure S160. ${ }^{19} \mathrm{~F}$ NMR (564 MHz, methylene chloride- $d_{2}, 299 \mathrm{~K}$ ) spectrum of compound 28k.

The crystal suitable for X-ray diffraction analysis was obtained from the solution of compound $\mathbf{2 8 \mathbf { k }}$ in pentane at $0^{\circ} \mathrm{C}$.

X-ray crystal structure analysis of compound 28k (erk9730): A yellow plate-like specimen of $\mathrm{C}_{38} \mathrm{H}_{34} \mathrm{BBrF}_{9} \mathrm{~N}_{2}$, approximate dimensions $0.060 \mathrm{~mm} \times 0.160 \mathrm{~mm} \times 0.220 \mathrm{~mm}$, was used for the X-ray crystallographic analysis. The X-ray intensity data were measured. A total of 1728 frames were collected. The total exposure time was 19.85 hours. The frames were integrated with the Bruker SAINT software package using a wide-frame algorithm. The integration of the data using a triclinic unit cell yielded a total of 29496 reflections to a maximum $\theta$ angle of $66.84^{\circ}$ ( $0.84 \AA$ resolution), of which 6271 were independent (average redundancy 4.704 , completeness $=98.8 \%, R_{\text {int }}=3.39 \%, R_{\text {sig }}$ $=2.57 \%)$ and $5782(92.20 \%)$ were greater than $2 \sigma\left(F^{2}\right)$. The final cell constants of $\underline{a}=8.7867(2) \AA$, $\underline{b}$ $=12.7686(2) \AA, \underline{c}=16.8144(3) \AA, \alpha=102.7230(10)^{\circ}, \beta=103.3830(10)^{\circ}, \gamma=91.8600(10)^{\circ}$, volume $=1783.25(6) \AA^{3}$, are based upon the refinement of the XYZ-centroids of 9881 reflections above 20 $\sigma(\mathrm{I})$ with $7.125^{\circ}<2 \theta<133.3^{\circ}$. Data were corrected for absorption effects using the multi-scan method (SADABS). The ratio of minimum to maximum apparent transmission was 0.844 . The calculated minimum and maximum transmission coefficients (based on crystal size) are 0.6370 and 0.8770. The structure was solved and refined using the Bruker SHELXTL Software Package, using the space group $P-1$, with $\mathrm{Z}=2$ for the formula unit, $\mathrm{C}_{38} \mathrm{H}_{34} \mathrm{BBrF}_{9} \mathrm{~N}_{2}$. The final anisotropic full-matrix least-squares refinement on $\mathrm{F}^{2}$ with 497 variables converged at $\mathrm{R} 1=3.16 \%$, for the observed data and $w R 2=8.23 \%$ for all data. The goodness-of-fit was 1.034 . The largest peak in the final difference electron density synthesis was $0.341 \mathrm{e}^{-/} / \AA^{3}$ and the largest hole was $-0.656 \mathrm{e}^{-} / \AA^{3}$ with an RMS deviation of $0.060 \mathrm{e}^{-} / \AA^{3}$. On the basis of the final model, the calculated density was $1.453 \mathrm{~g} / \mathrm{cm}^{3}$ and $\mathrm{F}(000), 794 \mathrm{e}$. The hydrogen at $\mathrm{N} 1$ atom was refined freely. CCDC number: 2041304. 


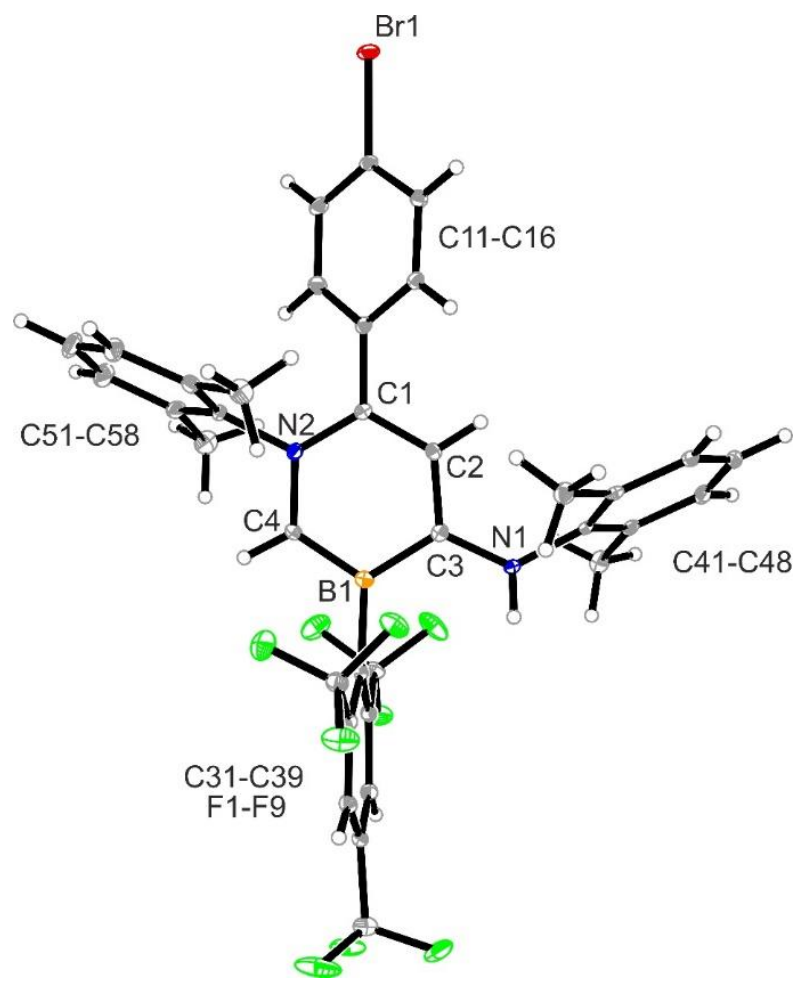

Figure S161. Crystal structure of compound 28k (thermal ellipsoids are set at 30\% probability).

\section{Photophysical part}

\section{General Procedures}

For UV-Vis and fluorescence measurements, spectroscopic grade solvents were used. Stock solutions of all compounds were prepared in THF $\left(c=1 \times 10^{-3} \mathrm{M}\right)$.

\section{UV-Vis spectroscopy}

UV-Vis absorption spectra were recorded on a JASCO V-750 with a spectral bandwidth of $1.0 \mathrm{~nm}$

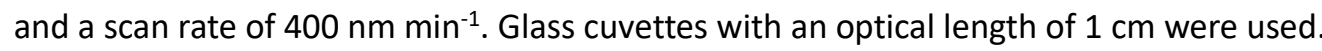

\section{Fluorescence spectroscopy}

Fluorescence spectra were recorded on a JASCO Spectrofluorometer FP-8500 in quartz cuvettes with an optical length of $1 \mathrm{~cm}$. The quantum yields $\left(\Phi_{\mathrm{F}}\right.$ ) of all samples in water [refractive index $(\eta)$ =1.33] were measured by using quinine sulfate as a standard which was dissolved in $0.1 \mathrm{M} \mathrm{H}_{2} \mathrm{SO}_{4}$ [refractive index $(\eta)=1.33$ ]. The absorbance intensities were kept below 0.1 in order to minimize re-absorption effects. Excitation wavelength $\left(\lambda_{\text {exc }}\right): 325 \mathrm{~nm}$ for $\mathbf{1 6 c - e}$ and $350 \mathrm{~nm}$ for the remaining compounds. 

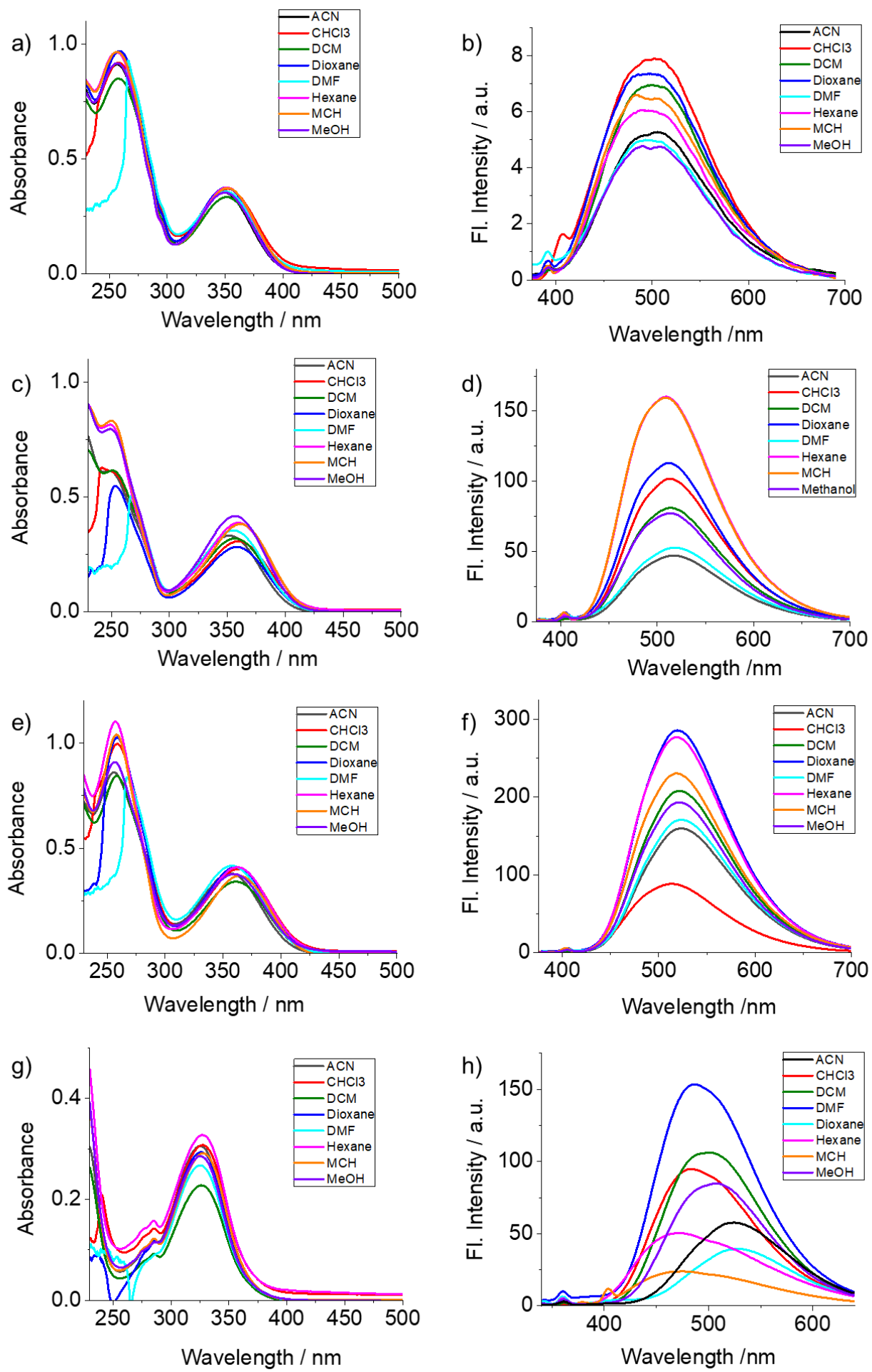

Figure S162. Absorption and emission changes of $10 b(a, b)$ 16a $(c, d), 16 b(e, f)$ and $16 c(g, h)$ in organic solvents of different polarity, conc. $(c)=10 \mu \mathrm{M}\left(1 \times 10^{-5} \mathrm{M}\right)$ and path length $(I)=1 \mathrm{~cm}$. 

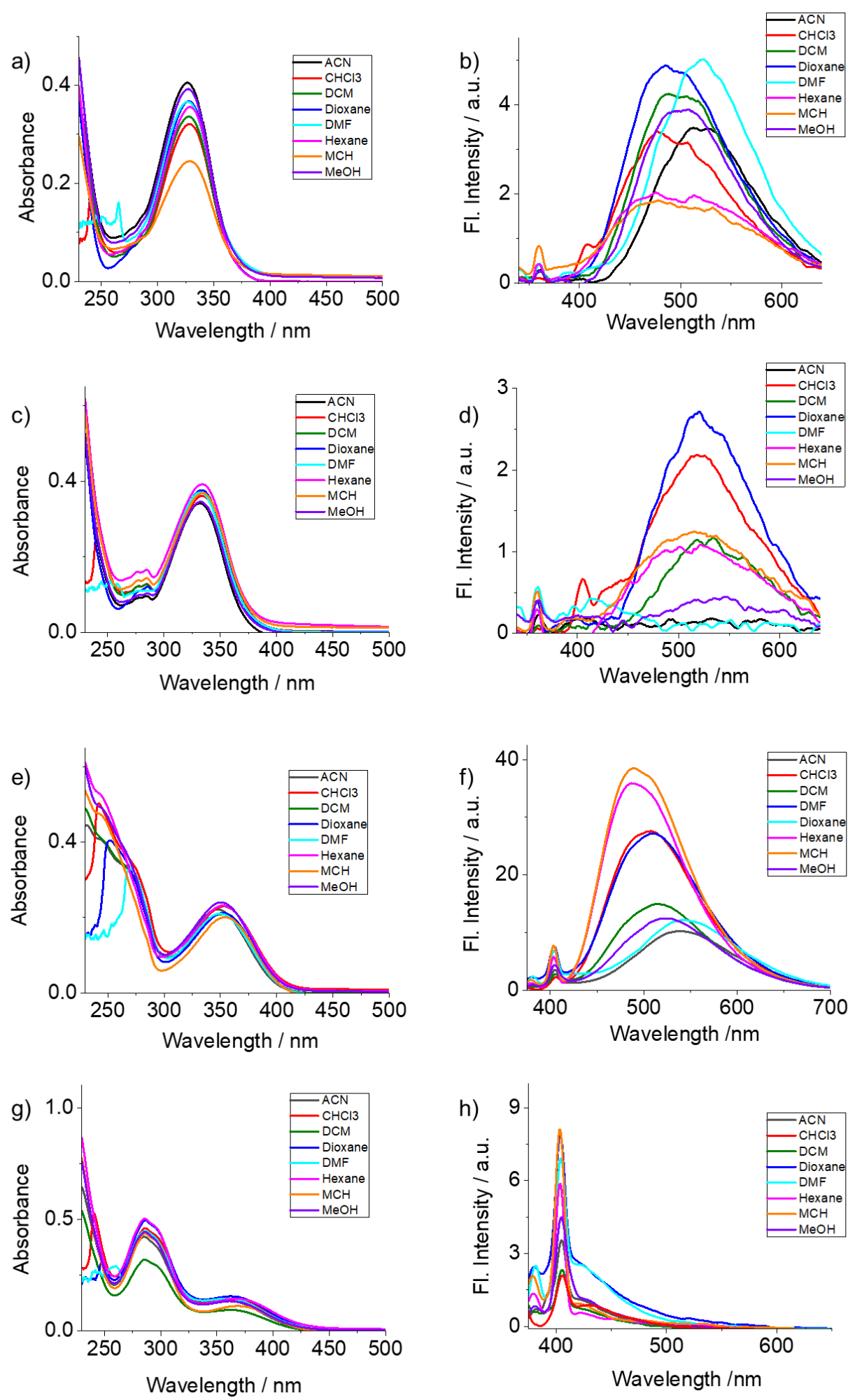

Figure S163. Absorption and emission changes of 16d (a, b) 16e (c, d), 16f (e, f) and $16 \mathrm{~g}(\mathrm{~g}, \mathrm{~h})$ in organic solvents of different polarity, conc. $(c)=10 \mu \mathrm{M}\left(1 \times 10^{-5} \mathrm{M}\right)$ and path length $(I)=1 \mathrm{~cm}$. 

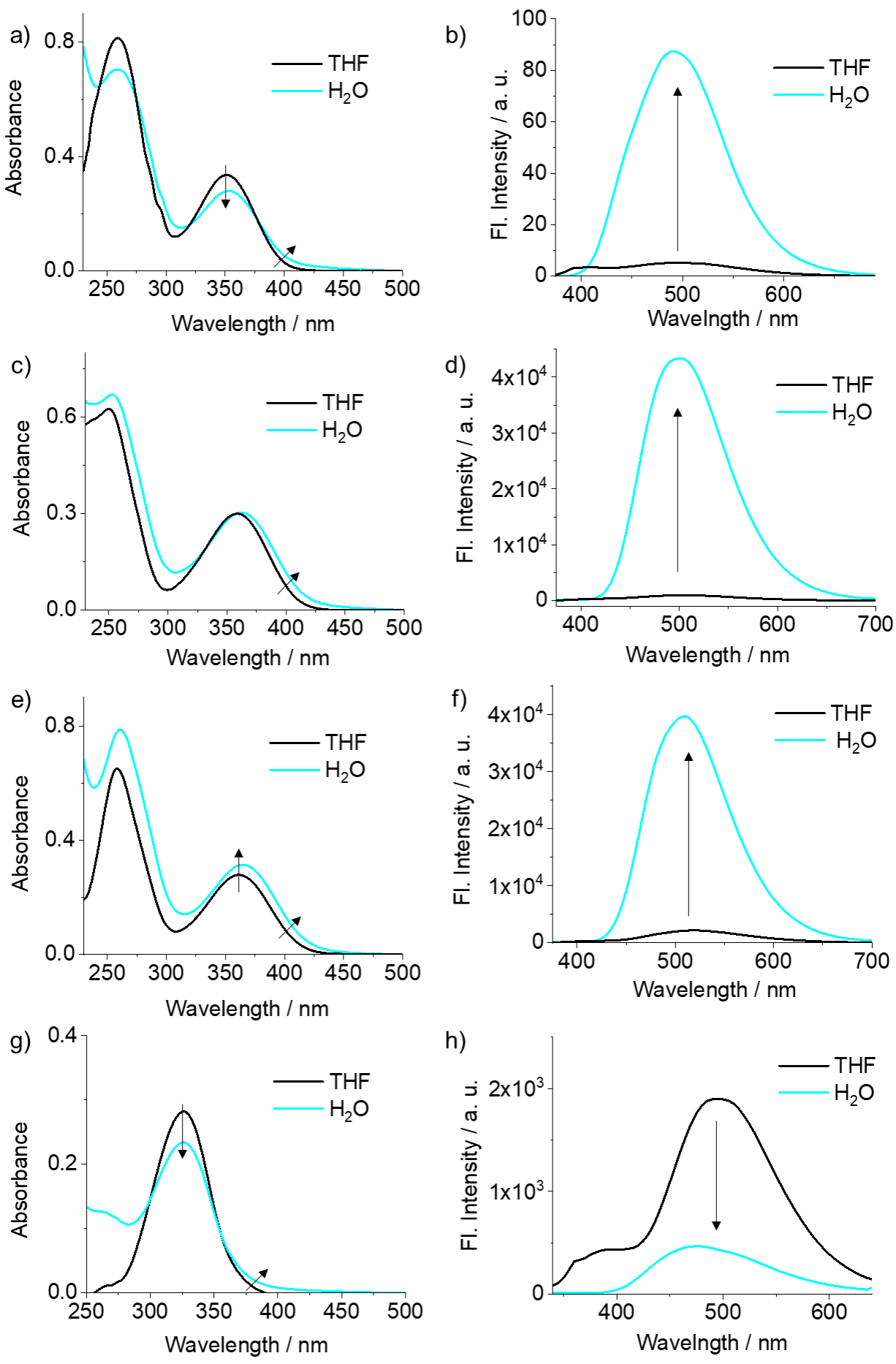

Figure S164. Absorption and emission changes of $10 b(a, b)$ 16a (c, d), 16b (e, f) and 16c (g, h) in water $\left(100 \%\right.$, cyan) and THF (100\%, black), conc. $(c)=10 \mu \mathrm{M}\left(1 \times 10^{-5} \mathrm{M}\right)$ and path length $(I)=1$ $\mathrm{cm}$. The arrows indicate the spectral progression upon addition of water. 

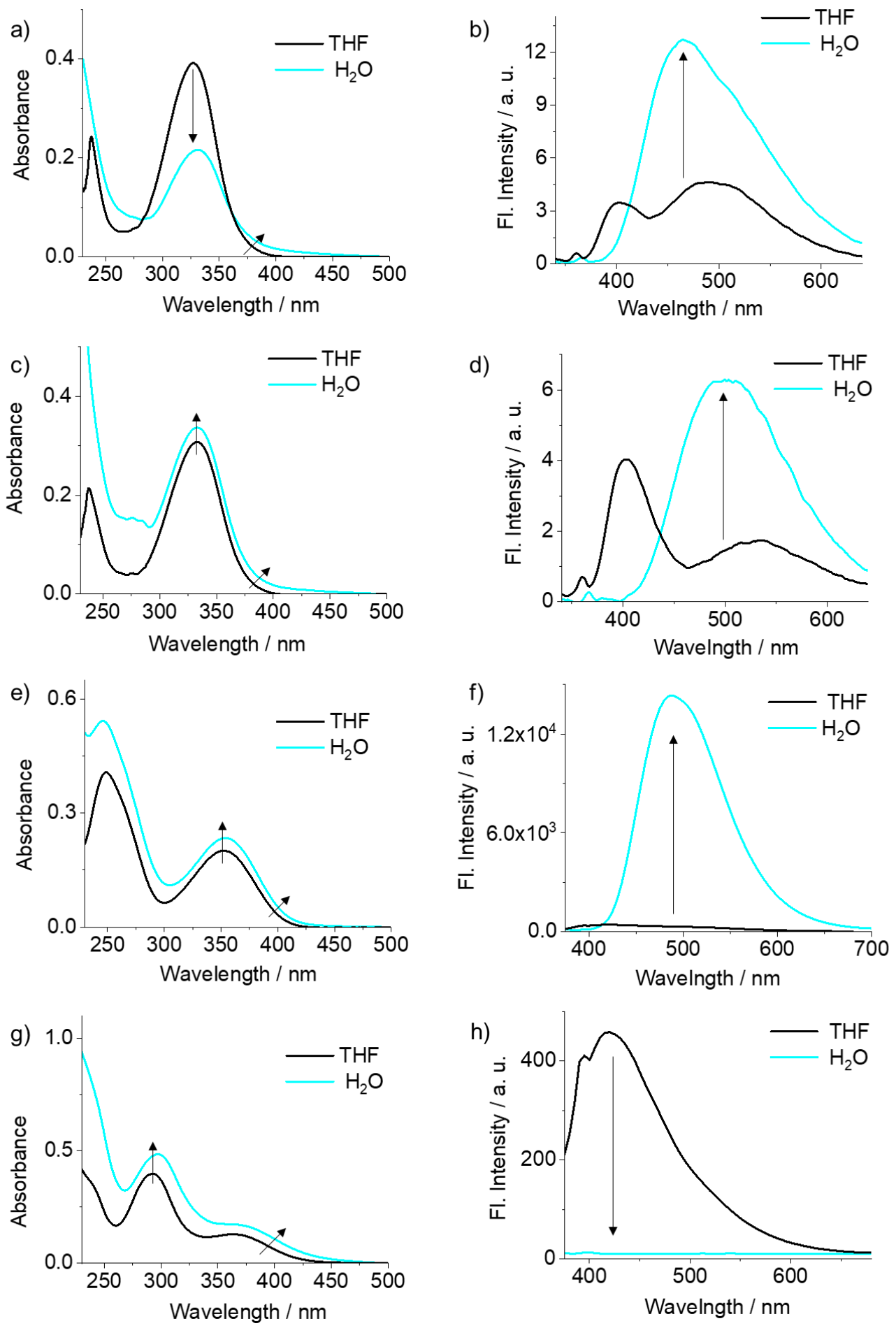

Figure S165. Absorption and emission changes of $16 \mathrm{~d}(\mathrm{a}, \mathrm{b}) \mathbf{1 6 e}(\mathrm{c}, \mathrm{d}), \mathbf{1 6 f}(\mathrm{e}, \mathrm{f})$ and $16 \mathrm{~g}(\mathrm{~g}, \mathrm{~h})$ in water $\left(100 \%\right.$, cyan) and THF $\left(100 \%\right.$, black), conc. $(c)=10 \mu \mathrm{M}\left(1 \times 10^{-5} \mathrm{M}\right)$ and path length $(I)=1$ $\mathrm{cm}$. The arrows indicate the spectral progression upon addition of water. 
Table S1. Relative fluorescence quantum yields $\left(\Phi_{\mathrm{F}}\right.$ of $16 \mathrm{a}-\mathrm{g}$ and $10 \mathrm{~b}$, estimated using quinine sulfate in $0.05 \mathrm{M} \mathrm{H}_{2} \mathrm{SO}_{4}\left(\Phi_{\mathrm{F}}=55 \%\right)$ as a reference.

\begin{tabular}{|c|c|c|}
\hline & $\begin{array}{c}\text { Relative quantum yield }\left(\Phi_{\mathrm{F}}\right) \\
(\%)\end{array}$ & $\begin{array}{c}2^{\text {nd }} \text { measurement with newly } \\
\text { synthesized material }\end{array}$ \\
\hline $\mathbf{1 6 a}$ & 68.6 & 65.1 \\
\hline $\mathbf{1 6 b}$ & 70.9 & 67.0 \\
\hline $\mathbf{1 6 c}$ & 4.2 & \\
\hline $\mathbf{1 6 d}$ & 0.38 & \\
\hline $\mathbf{1 6 e}$ & 0.22 & \\
\hline $\mathbf{1 6 f}$ & 64.8 & \\
\hline $\mathbf{1 6 g}$ & 0.1 & \\
\hline $\mathbf{1 0 b}$ & 0.47 & \\
\hline
\end{tabular}

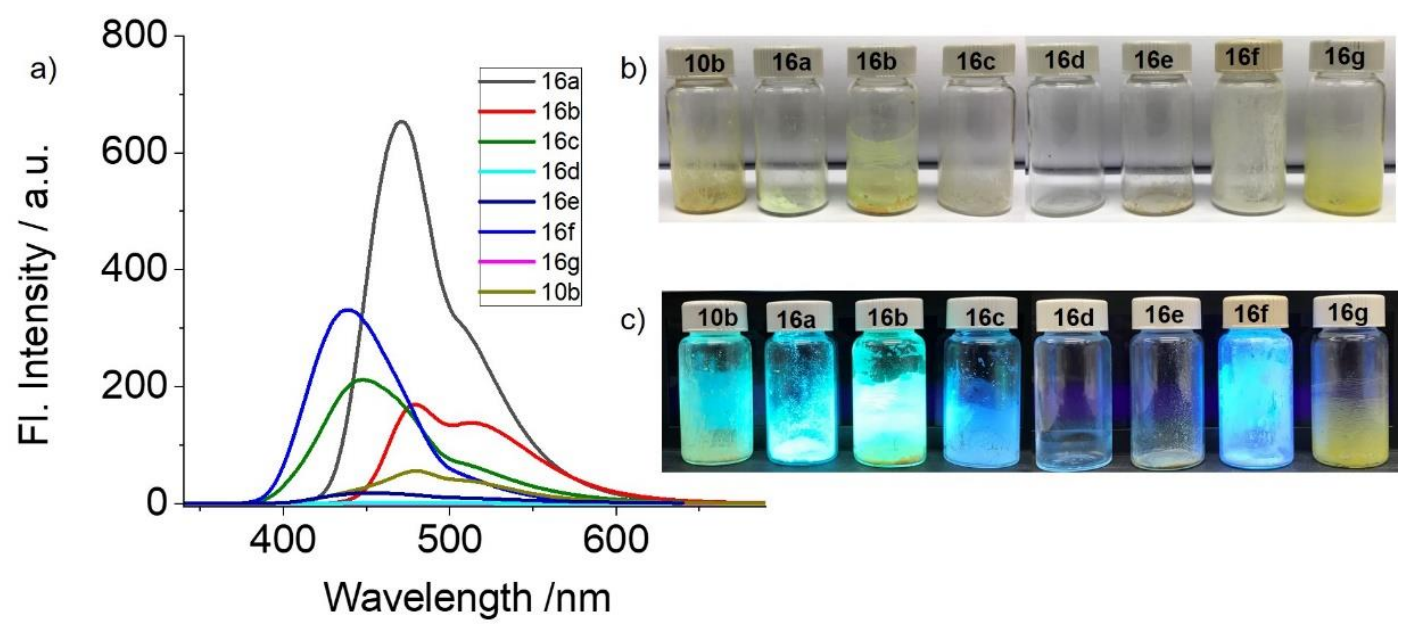

Figure S166. a) Solid-state emission spectra of $16 \mathrm{a}-\mathrm{g}$ (16d was a viscous oil in nature) and $10 \mathrm{~b}$ and corresponding photographs under daylight (b) and UV light (c).

\section{References}

(1) APEX3 (2016), SAINT (2015) and SADABS (2015), Bruker AXS Inc., Madison, Wisconsin, USA.

(2) Sheldrick, G. M., SHELXT - Integrated space-group and crystal-structure determination, Acta Cryst., 2015, A71, 3-8.

(3) Sheldrick, G.M., Crystal structure refinement with SHELXL, Acta Cryst., 2015, C71 (1), 3-8.

(4) XP - Interactive molecular graphics, Version 5.1, Bruker AXS Inc., Madison, Wisconsin, USA, 1998.

(5) Hooft, R. W. W., Nonius B. V., COLLECT, Program for Collecting Data on CCD Area Detectors, 1998, Delft, The Netherlands.

(6) Z. Otwinowski, W. Minor, Methods Enzymol. 1997, 276, 307 - 326.

(7) Z. Otwinowski, D. Borek, W. Majewski, W. Minor, Acta Crystallogr. Sect. A 2003, 59, 228 - 234.

(8) Li, J.; Daniliuc, C. G.; Kehr, G.; Erker, G., Preparation of the Borane (Fmes) $\mathrm{BH}_{2}$ and its Utilization in the FLP Reduction of Carbon Monoxide and Carbon Dioxide. Angew. Chem. Int. Ed. 2019, 58, 6737-6741. 